THELMA DE MESQUITA GARCIA E SOUZA

\title{
O DEVER DE INFORMAR E SUA APLICAÇÃO AO CONTRATO DE SEGURO
}

\author{
TESE DE DOUTORADO
}

Orientadora: Professora Associada Rachel SzTajn

FACULDADE DE DIREITO DA USP

SÃO PAULO

2012 
THELMA DE MESQUITA GARCIA E SOUZA

\title{
O DEVER DE INFORMAR E SUA APLICAÇÃO AO CONTRATO DE SEGURO
}

\author{
Tese de Doutorado apresentada à Banca Examinadora da Faculdade \\ de Direito da Universidade de São Paulo, como exigência parcial \\ para a obtenção do título de Doutor em Direito, sob a orientação da \\ Profa. Associada Rachel Sztajn
}

FACULDADE DE DIREITO DA USP

SÃO PAULO

2012 
Banca Examinadora 


\section{AGRADECIMENTOS}

À professora Rachel Sztajn, pela generosidade com que compartilha o conhecimento, pelo estímulo à reflexão com proposições instigantes, por sua dedicação na revisão minuciosa do texto, além da demonstração de solidariedade durante esse longo convívio;

Às professoras Vera Helena de Mello Franco e Juliana Krueger Pela, por suas valiosas sugestões na banca de qualificação, e especialmente à professora Juliana, pela oportunidade de discutir o tema sob novos prismas, em aula e em conversas informais;

Aos professores Haroldo Malheiros Duclerc Verçosa, Marcos Paulo de Almeida Salles, Erasmo Valladão Azevedo e Novaes França, Francisco Satiro de Souza Junior, Paulo Fernando Campos Salles de Toledo, Newton Silveira, Luciano Benetti Timm, Cristiano Carvalho e Milton Barossi, por tudo o que com eles aprendi nesses anos;

Aos colegas de escritório sou muito grata pelo incentivo e compreensão, apesar da carga extra de trabalho suportada na minha ausência;

À minha família, pelo carinho e apoio com os quais eu já sabia que podia contar. 


\section{RESUMO}

\section{O dever de informar e sua aplicação ao contrato de seguro}

Este estudo trata da informação que permeia os contratos e de sua aplicação ao contrato de seguro, da perspectiva do Direito e da Economia, ciências sociais que se complementam, porque aplicadas à mesma realidade, que será mais fielmente retratada se analisada sob ângulos diferentes, mas correlatos.

Perquirindo a função da informação no contrato, constata que, se concernente a elemento essencial deste, a ele adere, passando a integrá-lo, o que determina sua importância nesse contexto e indica o regime jurídico que lhe deve ser aplicado. A investigação da distribuição da informação entre os contratantes e dos efeitos eventualmente nocivos da assimetria informacional, como o incentivo ao oportunismo, o aumento dos custos de transação e a obtenção de ganhos indevidos do contrato, induz à discussão dos critérios orientadores da disciplina jurídica da informação no âmbito contratual.

A despeito da utilidade dos padrões para disciplinar condutas não alcançadas pelas regras, este estudo aponta que a boa-fé, em razão de suas idiossincrasias, não é padrão eficiente para reger a informação nos contratos, devendo ficar relegada à função residual. A aplicação do dever de informar com o objetivo de impor às partes transparência e veracidade conferiria mais objetividade e operacionalidade ao regime da informação nos contratos. Mas, a despeito da questionável eficiência da boa-fé como indutora da troca de informações entre as partes, foi o padrão de conduta escolhido pelo sistema jurídico para balizar a interação dos contratantes.

Devido às peculiaridades do contrato de seguro, e à nocividade dos efeitos da assimetria informacional neste contexto, exige-se dos contratantes a máxima boa-fé. Se a regra é a máxima transparência e a absoluta veracidade, deverá ser restritiva a interpretação de eventuais exceções. Como a informação se prende ao cerne da operação econômica subjacente, afetando o cálculo do risco e a fixação do prêmio, e consequentemente, a mutualidade, diz respeito à função e à finalidade do instituto. Por isso, a interpretação condescendente de eventuais omissões ou distorções de informação relevante afrontaria o princípio da máxima boa-fé, que não pode ser mitigado, sob pena de comprometer o equilíbrio do contrato e afetar sua finalidade sócio-econômica. 
O estudo demonstrou a inadequação do tratamento da informação em relação ao substrato econômico do contrato de seguro, especialmente no que concerne à exigência de comprovação da má-fé nas omissões e distorções da verdade pelo segurado. Criticou também a aplicação dogmática da presunção da boa-fé, que reverte ao segurador o ônus da prova da má-fé do segurado, anulando o efeito sancionador da imposição do dever de informar.

Palavras-chave: incerteza - risco - informação - assimetria informacional - oportunismo máxima boa-fé - dever de informar - custos de transação externalidades - contrato de seguro - mutualidade 


\section{ABSTRACT \\ Duty to inform and its application to insurance contracts}

The purpose of this dissertation is to analyze the importance of information in contract law, the disclosure duties and its application to insurance contracts, from legal and economic perspectives. Since Law and Economics are social sciences applied to the same environment and are mutually complementary, this bifocal approach leads to a more accurate portrait of reality seen from different but correlated points of view.

The analysis of the role of information reveals that if it concerns the contract essential element, it becomes part of it and determines the legal rules that should be applied to it. The inquiry of information distribution patterns shows that it can eventually bring about detrimental effects which induce the discussion of the criteria underlying the legal regime of information in contract law. Asymmetric information can be harmful if it encourages opportunism, increases transaction costs and grants one party undue gains from the contract.

In spite of the usefulness of standards to regulate conducts not reached by rules, this study shows that good faith, due to its idiosyncrasies, is not an efficient standard to govern information in contracts. Thus, it should be assigned a residual function. The application of the duty to inform with the purpose of imposing full disclosure and accuracy to the parties ensures more objectivity to the information regime in contracts. However, good faith was the standard chosen by the legal system to rule the parties' interaction, despite its recognized inefficiency to induce information exchange among agents.

Due to the particular features of the insurance contract, and to the harmful effects of informational asymmetry in this context, law imposes the parties a higher standard of good faith. If the legal standard is the utmost good faith, eventual exceptions to this pattern should be restrictively interpreted. Since information is connected with the economic mechanism of the insurance contract because it affects risk and premium evaluation, it is strictly related to the function and purpose of the contract. Therefore, condescending interpretation of nondisclosure, misrepresentation and fraud would violate the principle of utmost good faith. Its mitigation will affect the contract balance and its economic and social purposes. 
This dissertation demonstrates the inadequacy of the information legal regime, especially regarding the requirement of proving bad faith related to nondisclosure, misrepresentation or fraud. It also criticizes the dogmatic application of the presumption of good faith that lays upon the insurer the burden of proving bad faith of the insured's conduct, nullifying the sanctioning effect of the imposition of the duty to inform.

Keywords: uncertainty - risk - information - information asymmetry - opportunism utmost good faith - duty to inform - transaction costs - externalities insurance contract - insurance pool. 


\section{RÉSUMÉ}

\section{Le devoir d'informer et son application au contrat d'assurance}

Cette étude porte sur l'information qui concerne les contrats et son application au contrat d'assurance, la perspective du Droit et de 1'Économie, des sciences sociales qui se complètent, parce qu'elles sont appliquées à la même réalité, qui est plus fidèlement révélée si elle est analysée sous des angles différents, mais corrélatifs.

En recherchant attentivement la fonction de l'information dans le contrat, on constate que si concernant à l'élément essentiel de celui-ci, à lui adhère, passant à l'intégrer, ce qui détermine son importance dans ce contexte et indique le régime juridique qui lui doit être appliqué. La recherche de la distribution de l'information entre les parties contractantes et des effets éventuellement nocifs de l'asymétrie informationnelle, comme l'incitation à l'opportunisme, l'augmentation des coûts de transaction et à l'obtention des gains impropres dans le contrat entraîne la discussion des critères qui orientent la discipline juridique de l'information dans la sphère contractuelle.

En dépit de l'utilité des paramètres pour discipliner les conduites non atteintes par les règles, cette étude démontre que la bonne foi, en raison de ses idiosyncrasies n'est pas de paramètre efficient pour contrôler l'information dans les contrats et doit rester reléguée à la fonction résiduelle. L'application du devoir d'informer ayant l'objectif d'imposer aux parties la transparence et la véracité accorderait plus d'objectivité et de caractère opérationnel au régime de l’information dans les contrats.

Malgré l'efficacité questionnée de la bonne foi comme conductrice de l'échange des informations entre les parties, il a été le paramètre de conduite choisi par le système juridique pour borner l'interaction des parties contractantes. Dû aux particularités du contrat d'assurance et à la nocivité des effets de l'asymétrie informationnelle dans ce contexte, on exige des parties contractantes la plus absolue bonne foi. Si la règle est la plus grande transparence et la véracité absolue, devra être restrictive à l'interprétation des exceptions.

Comme l'information s'attache à l'essence de l'opération économique subjacente, affectant le calcul du risque et la fixation de la prime, et par conséquent, la mutualité, elle porte sur la fonction et à la finalité de l'institut. Pour cela, l'interprétation bienveillante des 
éventuelles omissions où distorsions de l'information pourrait défier le principe de la plus absolue bonne foi qui ne peut pas être atténué, sous la peine de compromettre l'équilibre du contrat et affecter sa finalité socio-économique.

L'étude a démontré l'inadéquation du régime d’information par rapport au substrat économique du contrat d'assurance, spécialement en ce qui concerne l'exigence de la preuve de la mauvaise foi relative aux omissions et les distorsions de la vérité par l'assuré. La critique a été aussi faite quant à l’application dogmatique de la présomption de la bonne foi qui remet à l'assureur la charge de la preuve de la mauvaise foi de l'assuré, annulant l'effet sanctionnant de l'imposition du devoir d'informer.

Mots Clés: Incertitude - risque - information - asymétrie informationnelle - opportunisme - bonne foi - uberrima fides - devoir d'informer - coûts de transaction externalités - contrat d'assurance - mutualité. 


\section{SUMÁRIO}

INTRODUÇÃO

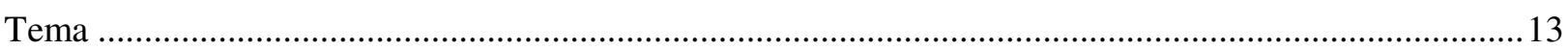

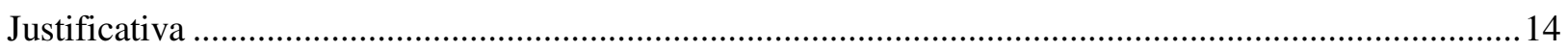

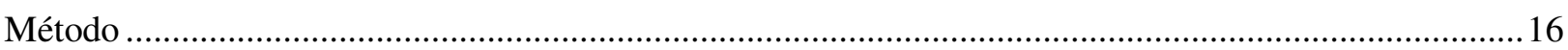

CAPÍTULO 1. A INCERTEZA E O PROCESSO DE ESCOLHA .......................................... 19

Incerteza e Informação........................................................................................ 19

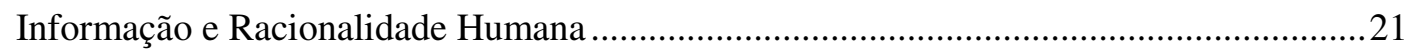

Evolução do Pensamento Econômico e Jurídico Relativo à Informação...............................23

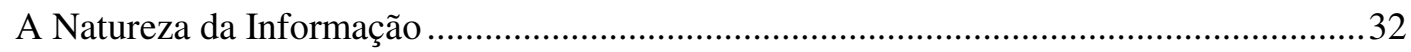

A função e a importância da informação que instrui o contrato ...........................................33

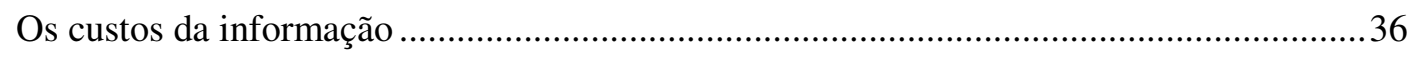

CAPÍTULO 2. A ASSIMETRIA INFORMACIONAL E AS INSTITUIÇÕES:

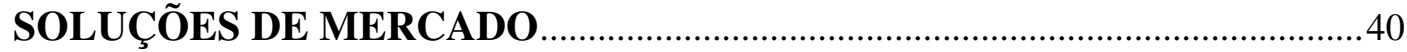

A distribuição de informação entre os agentes ................................................................... 40

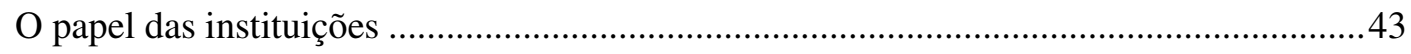

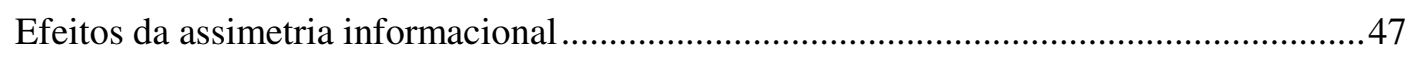

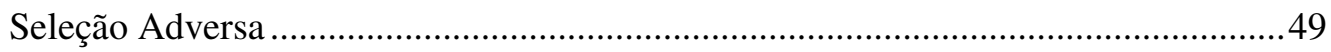

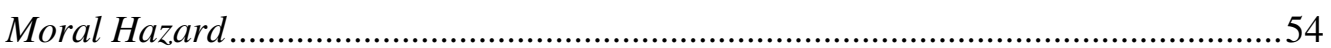

Soluções de mercado para redução dos efeitos da assimetria informacional........................58

Signaling: A sinalização promovida pela parte mais informada...................................58

Screening: Escrutínio promovido pela parte menos informada ..................................60

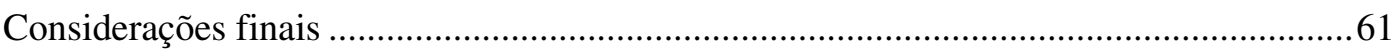

\section{CAPÍTULO 3. ASSIMETRIA INFORMACIONAL E AS INSTITUIÇÕES:} REGIME DA INFORMAÇÃO NOS CONTRATOS …......................................63

Regras básicas de distribuição do ônus da informação entre os contratantes ......................63

Linhas gerais da disciplina da informação relativa aos contratos .....................................65

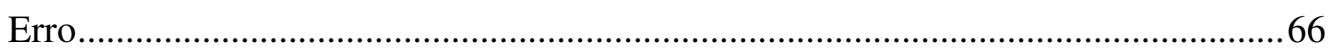

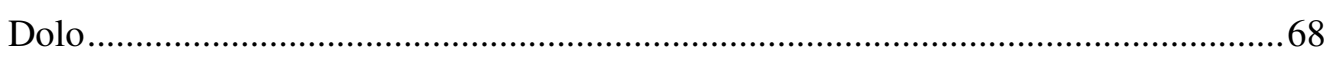

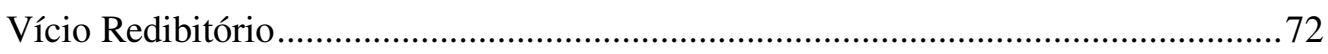

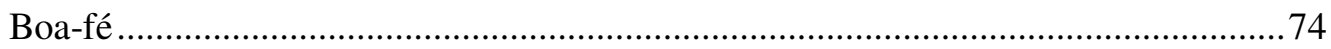

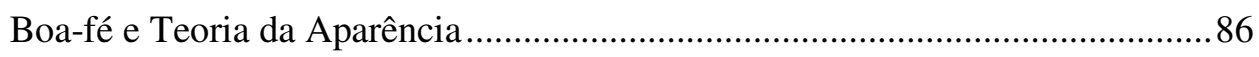

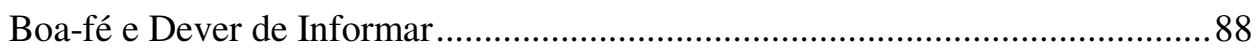

CAPÍTULO 4. BOA-FÉ E DEVER DE INFORMAR NO DIREITO COMPARADO ........ 94

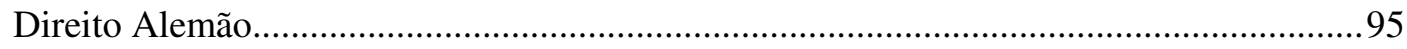

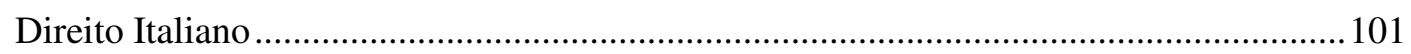

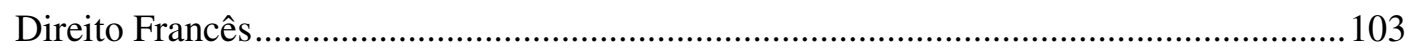




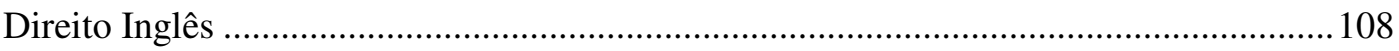

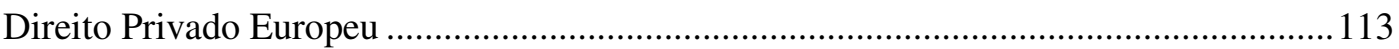

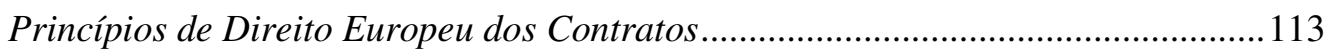

Projeto do Código Europeu dos Contratos ................................................................116

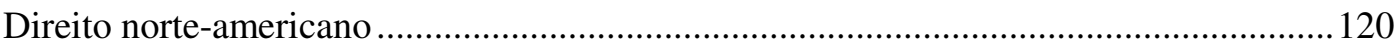

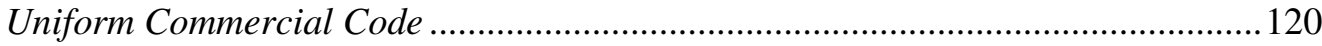

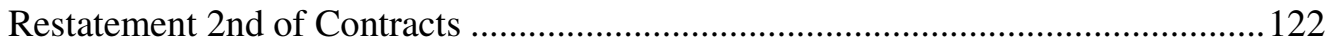

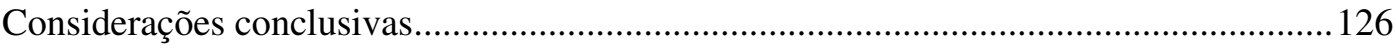

CAPÍTULO 5. PERSPECTIVA ECONÔMICA DO DEVER DE INFORMAR .................. 133

Discussão das teorias formuladas pela Análise Econômica do Direito ...............................133

A crescente preocupação com a lealdade contratual e a tutela da informação ...................146

Dever de informar. Pressupostos e Fundamentos .............................................................. 147

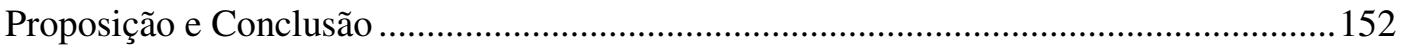

CAPÍTULO 6. INFORMAÇÃO E OS SEGUROS PRIVADOS .......................................... 158

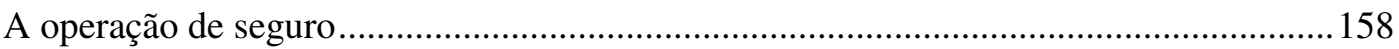

Aspecto técnico-econômico da operação de seguros ...........................................................159

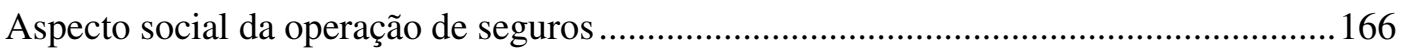

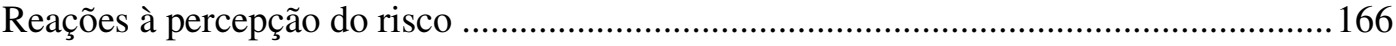

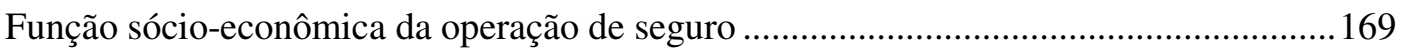

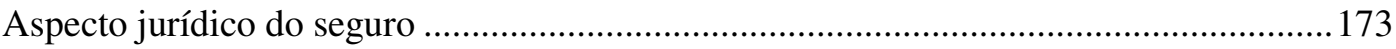

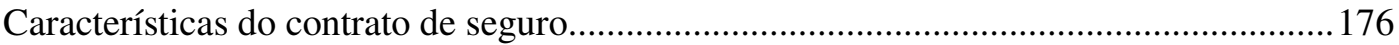

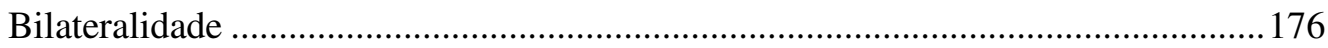

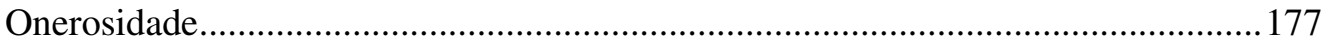

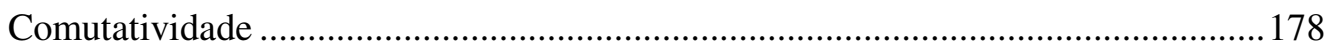

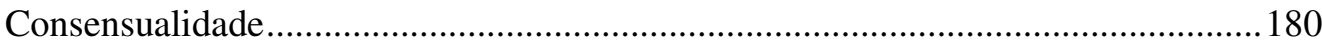

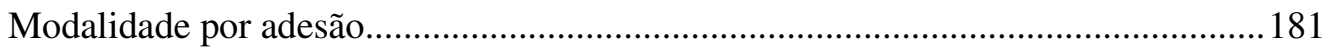

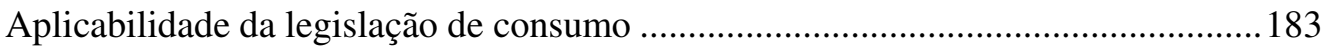

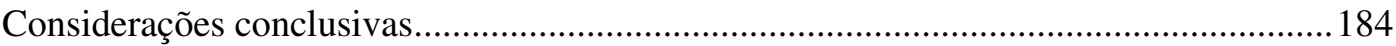

CAPÍTULO 7: OS ELEMENTOS DO CONTRATO DE SEGURO ….................................. 185

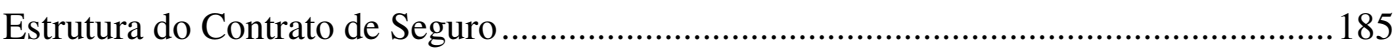

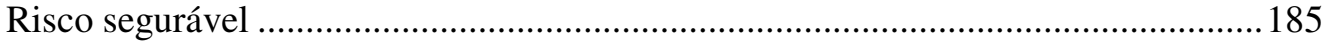

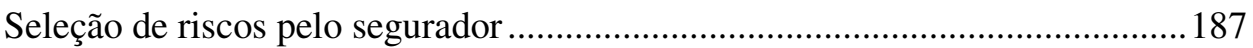

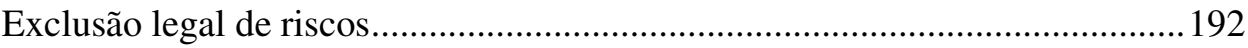

O risco como medida de cálculo do prêmio .........................................................193

Exclusão contratual de riscos ...................................................................... 193

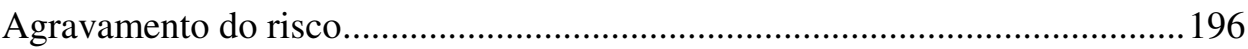

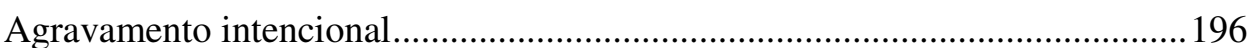

Agravamento sem culpa do segurado ............................................................. 198

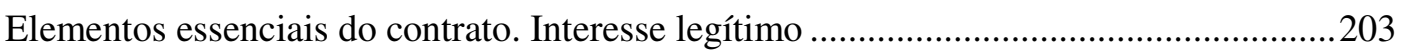

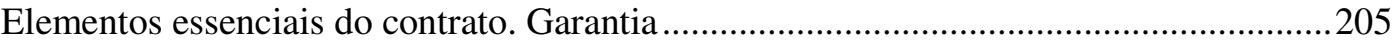




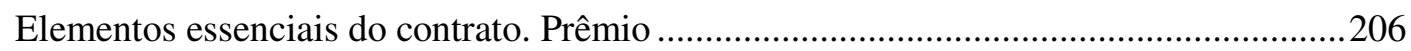

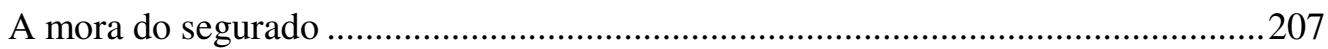

Estrutura do Contrato de Seguro. Elementos acidentais ...................................................210

Elementos acidentais. Sinistro e Indenização..........................................................210

CAPÍTULO 8. DEVER DE INFORMAR NO CONTRATO DE SEGURO ........................212

Omissões e inexatidões como atributos do risco .............................................................212

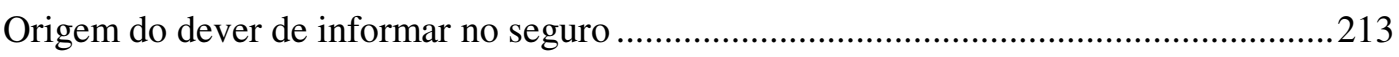

Natureza do dever de informar no contrato de seguro ...................................................2. 215

Objeto do dever de informar em matéria de seguro......................................................216

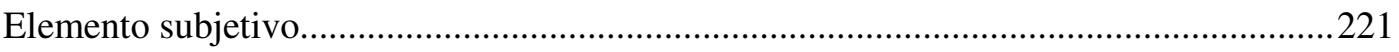

Relevância da informação omitida ou distorcida. Critérios de aferição ............................224

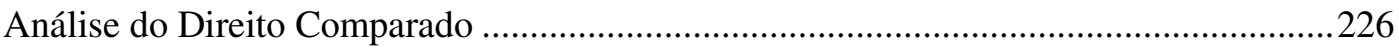

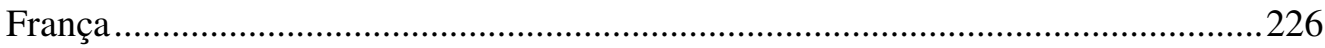

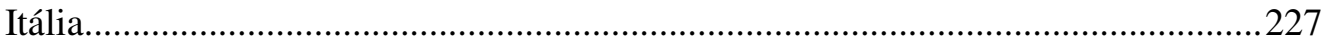

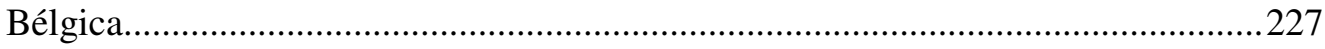

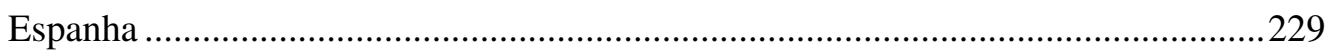

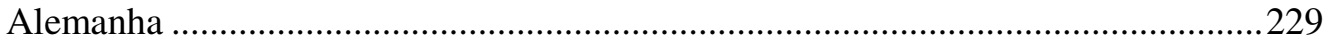

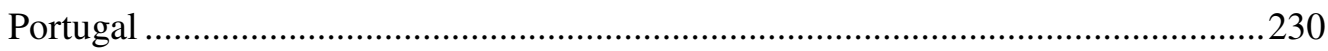

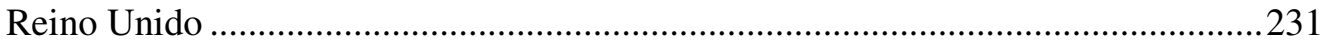

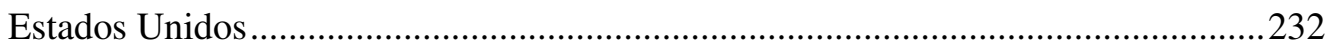

Brasil. Regime Legal do Dever de Informação no Contrato de Seguro...............................232

Disciplina das declarações do proponente...............................................................232

Disciplina do dever de informar no curso do contrato .............................................237

Comunicação do agravamento do risco ............................................................237

Comunicação da ocorrência do sinistro ...........................................................238

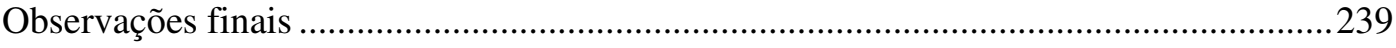

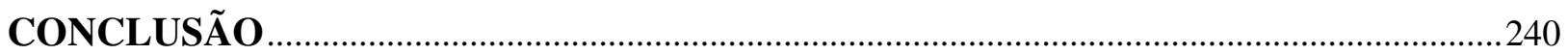

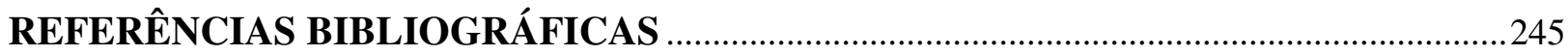




\section{INTRODUÇÃO}

Tema

O foco deste trabalho é a importância da informação no contexto contratual, a função e a disciplina jurídica do dever de informar e sua aplicação ao contrato de seguro.

Como tal abordagem implica o enfoque do risco, traçamos a relação entre esses dois elementos, informação e risco, estreitamente conexos entre si, porque um viabiliza a quantificação e avaliação do outro.

O controle do risco, fenômeno cada vez mais impregnado na atividade humana, constitui um dos traços distintivos da sociedade moderna. Transformou a passividade ante o determinismo do destino em capacidade de administração do futuro, por meio da estatística, de modelos matemáticos e das ciências atuariais, influindo decisivamente no processo de escolha racional ${ }^{1}$.

No âmbito da economia, o estudo da informação e o reconhecimento de suas imperfeições e dos efeitos delas decorrentes, assim como dos custos de obtê-la, e a consequente flexibilização do modelo econômico tradicional representou notável evolução em relação ao passado.

O campo de pesquisa pertinente à informação que permeia os contratos, pouco explorado até agora no Brasil, suscita questões instigantes relacionadas à sua distribuição entre os contratantes, à função que exerce e à eficiência das normas que a disciplinam.

O contrato de seguro, a par da relevância sócio-econômica do instituto, é o melhor exemplo da importância da informação em matéria contratual. Tratar de seguro implica discutir risco, pois é um dos meios de administrá-lo, por garantir proteção contra efeitos patrimoniais adversos ou necessidades decorrentes de eventos incertos ${ }^{2}$. E o tratamento do risco pressupõe a abordagem da informação, que viabiliza sua mensuração e avaliação.

\footnotetext{
${ }^{1}$ BERNSTEIN, Peter. Desafio aos deuses, a fascinante história do risco. 23. ed. Trad. Ivo Korylowski do original Againt the gods. Rio de Janeiro: Elsevier, 1997. p. 1-3.

${ }^{2}$ Sztajn delineia bem o perfil desse tipo contratual: "o seguro cria uma proteção contra os efeitos negativos causados pelo sinistro, isto é, a realização do risco, para que o cálculo atuarial oferece embasamento técnico, permite estimar a probabilidade de ocorrência do sinistro, sua frequência na comunidade e organizar rede de proteção na forma de garantias recíprocas que se dão pessoas sujeitas ao mesmo evento." SZTAJN, Rachel. Sistema financeiro. Rio de Janeiro: Elsevier, 2011. p. 63.
} 


\section{Justificativa}

A escolha do tema se justifica pela fundamental importância da informação para a eficiência e o equilíbrio dos contratos, especialmente o de seguro, e por ser uma das questões menos discutidas nos textos jurídicos.

Não se pretende aqui, portanto, um estudo abrangente do contrato de seguro, mas um enfoque direcionado principalmente à informação que permeia o processo de contratação, tanto na formação como na execução contratual. Nessa perspectiva, abordaremos o contrato de seguro, seu objeto, função e peculiaridades, na medida da necessidade de caracterização do instituto e da pertinência com o tema central.

A informação é recurso valioso, não só quando constitui objeto dos contratos de propriedade intelectual. Ao dissipar a incerteza, desempenha função essencial no processo de escolha dos agentes. Funciona como indutor da atividade negocial, fator de incentivo ao comprometimento das partes desde a formação do contrato, e até como elemento definidor do objeto e das condições da contratação, estabelecendo as bases sobre as quais se assenta o negócio jurídico e legitimando o consentimento das partes.

No contrato de seguro, a importância da informação é mais acentuada, pois as declarações do proponente são a base para o juízo de admissibilidade do risco e a medida para a tarifação do prêmio. A informação exerce, pois, papel essencial na formação desse contrato, e guarda estreita relação com o substrato econômico da operação de seguros, viabilizando a aferição do risco a ser coberto e o cálculo do preço da cobertura. É a informação que permite a mensuração do risco. E na fase de execução do contrato, que é tipicamente diferida no tempo, também se mantém a imposição do dever de informar, pois o segurador continua a depender quase exclusivamente das informações do segurado quanto a eventual agravamento do risco e às circunstâncias de possível sinistro. $\mathrm{O}$ monitoramento da conduta da contraparte, quando não é inviável, representa custo elevado, que afeta o preço da garantia.

Evidentemente o dever de informar é imposto a ambas as partes. Mas o teor das disposições do próprio Código Civil deixa entrever que a assimetria informacional onera mais o segurador do que o segurado, dadas as peculiaridades desse tipo contratual. A estrita regulação e supervisão do poder público sobre as companhias seguradoras e as condições gerais da contratatação, monitoradas, quando não predeterminadas, pela própria agência reguladora, assim como as sanções cominadas a falhas de informação imputáveis 
às seguradoras, reduzem muito a possibilidade de infração do dever de informar por parte destas. E se o negócio jurídico se classificar como relação de consumo, as restrições à deslealdade contratual e à falha de informação do fornecedor são punidas com maior rigor, incentivando a observância da lei.

A importância da informação está implícita nos dispositivos legais atinentes ao contrato de seguro. Ao exigir declaração escrita dos elementos essenciais do interesse a ser garantido e do risco, ao punir inexatidões ou omissões que influenciem a aceitação da proposta e ao determinar a imediata comunicação de circunstância apta a agravar o risco, a lei trata da informação que permeia o contrato, visando reduzir a assimetria informacional entre as partes. A imposição da mais estrita boa-fé e veracidade evidencia a importância da informação nesse contexto.

Este estudo abordará a relação entre boa-fé e dever de informar, traçando um paralelo entre a adoção de regras ou de princípios como balizadores da interação humana. Demonstrará a importância de destacar o dever de informação da gama de manifestações do princípio da boa-fé, por ser sua expressão mais objetiva, sendo, por isso, mais incisiva, e também mais facilmente mensurável, na diagnose da conduta dos contratantes, necessária à adequada aplicação da lei.

À luz do princípio da máxima boa-fé, orientador das relações de seguro, as partes contratantes têm o dever recíproco de informar todos os fatos e circunstâncias aptos a afetar o risco, desde que, obviamente, conhecidos de uma e desconhecidos da outra, ainda que a informação não tenha sido requisitada.

O contrato de seguro é um dos institutos jurídicos de maior utilidade e relevância sócio-econômica, em razão de sua função de deslocar os efeitos do risco, garantindo a recomposição patrimonial dos segurados, mediante a administração de um fundo de recursos comum a todos eles, que prestam assim garantias recíprocas. Como fator de estabilidade patrimonial, incentiva a atividade negocial e o desenvolvimento econômico.

A imperfeição informacional inerente ao mercado de seguros pode comprometer o equilíbrio contratual, promovendo incentivos que afetam o bem-estar social. Os efeitos dessa disparidade de informação entre as partes, tanto na fase pré-contratual, como no curso da execução do contrato, extrapolam as relações individuais e alcançam a mutualidade, dada a natureza e a função do contrato de seguro, disseminando-se eventualmente por toda a sociedade. 
Trataremos do efeito pré-contratual, conhecido como seleção adversa e derivado da dificuldade de identificação das características do produto ofertado ou dos atributos da contraparte aptos a afetar a relação jurídica, e do efeito pós-contratual, denominado moral hazard $^{3}$ e decorrente da dificuldade de monitoração do comportamento da contraparte no curso da execução do contrato. A par das soluções de mercado para esses problemas de seleção e de monitoração, como a sinalização (signalling) e a triagem (screening), abordaremos soluções jurídicas úteis para evitar, mitigar ou remediar os efeitos da assimetria informacional no âmbito do seguro privado. Estas concernem, de um modo geral, à estrita observância do dever de informar nas múltiplas circunstâncias em que cada caso concreto poderia suscitar seu descumprimento.

\section{Método}

Como a informação foi focalizada, em estudos teóricos e práticos, mais pela Economia que pelo Direito, não seria razoável enfocá-la sob a óptica jurídica sem nos valermos de alguns dos subsídios valiosos já providos pelos economistas.

Além disso, Economia e Direito são ciências sociais aplicadas e, como tal, se aplicam ao mesmo contexto. Se a realidade sobre a qual incidem é a mesma, embora suas perspectivas sejam diferentes, não podem ser tratadas como departamentos estanques. Essa interação entre as duas se reflete no contrato, que, como diz Roppo, um dos expoentes da doutrina tradicional, é a veste jurídica das operações econômicas ${ }^{4}$. A utilidade deste conceito é não se restringir à estrutura do instituto, mas retratar-lhe a função econômica, que é servir à finalidade de circulação de riqueza, deixando entrever o papel instrumental do contrato, a despeito de sua autonomia no plano jurídico. Embora o contrato seja um instituto autônomo, disciplinado por regras próprias, dotado de seus próprios estatutos lógicos, e identificável segundo a universalidade de conceitos e categorias que lhe são

\footnotetext{
${ }^{3}$ Mantivemos aqui a expressão em inglês, porque a tradução risco moral, é um significante que trai o significado do original, não correspondendo à sua exata acepção, razão pela qual daria margem a ambiguidades.

${ }^{4}$ ROPPO, Vincenzo. Il contratto. Milano: Giuffrè, 2001. p. 72-73. (Trattato di Diritto Privato a cura di Giovanni Iudica e Paolo Zatti). Nessa obra, o autor só revela esta feição do contrato no tópico dedicado à abordagem da Análise Econômica do Direito. Mas, anos depois, na edição do livro escrito para atualizar as ideias e sintonizá-las com a evolução do direito contratual nas três décadas que o separam da primeira edição, ele sintomaticamente assume a visão antes atribuída à Law and Economics e enclausurada num tópico específico, adotando esse conceito de veste jurídica da operação econômica, que evidencia a função do contrato. ROPPO, Enzo. O contrato. Trad. Ana Coimbra e M. Januário C. Gomes. Lisboa: Almedina, 2009. p. 7-8.
} 
peculiares, essa construção jurídica não pode ser um fim em si mesma, mas um instrumento da respectiva operação econômica ${ }^{5}$.

Assim, como este estudo trata da informação concernente ao contrato, não poderia desprezar a operação econômica a este subjacente, sob pena de se restringir apenas à veste jurídica. O contrato, que existe no mundo ideal, simplesmente não se materializa no mundo real sem seu substrato econômico. E se dele se tratasse como uma abstração, a utilidade de tal abordagem seria nenhuma. Qualquer discussão que desconsidere o elemento econômico subjacente ao contrato será imprestável.

Mais que um instituto jurídico ${ }^{6}$, portanto, contrato é uma instituição social cuja finalidade sócio-econômica é promover a livre e voluntária circulação de riquezas, reduzir os custos envolvidos no processo de negociação, contratação e posterior execução do pactuado $^{7}$, bem como assegurar mais eficiência na alocação de recursos, na distribuição de riscos entre as partes e no cumprimento das obrigações pactuadas.

Assim, se por um lado, o fato econômico é relevante porque é a realidade que dá sustentação material ao contrato, justificando sua existência e definindo-lhe a natureza e a função, de outro, o direito contratual tem um papel fundamental como modelador do intercâmbio econômico. O Direito compõe o conjunto das regras formais que balizam a interação humana $^{8}$, induzindo comportamentos, incentivando ou desestimulando ações, reduzindo ou aumentando a incerteza jurídica e os custos de transação, estabelecendo uma estrutura que poderá garantir a previsibilidade do sistema jurídico e econômico. Esta é a função promocional do Direito, que tem finalidade não só repressiva, mas também persuasiva, como observou Norberto Bobbio, cujo estudo ${ }^{9}$ revelou essa feição sociológica do Direito, como fator condicionador de comportamentos.

Como instituição modeladora da interação dos agentes no mercado, ao direito contratual incumbem relevantes funções, como $^{10}$ :

\footnotetext{
${ }^{5}$ ROPPO, Enzo. O contrato, cit., p. 9-10.

${ }^{6} \mathrm{Na}$ acepção clássica de acordo de vontades firmado para adquirir, resguardar, modificar ou extinguir direitos.

${ }^{7}$ COASE, Ronald. The problem of social cost. In: COASE, Ronald. The firm, the market and the law. Chicago: The University of Chicago Press, 1988. p. 114.

${ }^{8}$ NORTH, Douglas. Institutions, institutional change and economic performance. New York: Cambridge University Press, 1990. p. 3.

${ }^{9}$ BOBBIO, Norberto. Da estrutura à função: novos estudos de teoria do direito. Trad. de Daniela Beccaccia Versiani. São Paulo: Manole, 2007. p. 1-21.

${ }^{10}$ Essas funções correspondem aos objetivos traçados por COOTER, R.; ULEN, T. Law and economics. $4^{\text {th }}$ ed. Boston: Pearson Addison Wesley, 2004. p. 235.
} 
(i) estimular a cooperação entre as partes;

(ii) incentivar a troca mais eficiente de informações entre os contratantes;

(iii) assegurar o comprometimento dos agentes;

(iv) garantir bom nível de confiabilidade nos contratos;

(v) reduzir custos de transação, disciplinando eficientemente os contratos e prevendo penalidades para o descumprimento; e

(vi) encorajar relações jurídicas duradouras, que induzem à cooperação entre contratantes.

Em relação ao tema ora estudado, cumpre ao Direito prover incentivos para mitigar a assimetria informacional, quando esta provocar efeitos nocivos não sanáveis pelos instrumentos do mercado, com a finalidade de reduzir custos da contratação, estimular a cooperação e induzir as partes ao cumprimento de suas obrigações. A maior ou menor eficiência do Direito no desempenho de suas funções se refletirá no grau de desenvolvimento econômico do país e o bem-estar da sociedade.

Em suma, o estudo do tema buscou, a par do enfoque da análise jurídica tradicional, a perspectiva da Análise Econômica do Direito, que propõe a avaliação das normas pelos efeitos que elas provocam na conduta dos agentes, balizando o comportamento humano por meio dos incentivos e desincentivos que promovem.

O método Law and Economics não se propõe a substituir o método jurídico. É uma visão complementar, frequentemente convergente com a abordagem tradicional, mas com o foco direcionado mais para o aspecto funcional do que estrutural do contrato.

A adoção desse método é particularmente útil, neste caso, porque permite a aplicação de algumas importantes constatações da Economia da Informação ${ }^{11}$ à análise e disciplina da informação que permeia a contratação, das peculiaridades de sua natureza, dos custos de obtenção, e dos efeitos da distribuição assimétrica entre os agentes, tanto na formação como na execução do contrato.

\footnotetext{
${ }^{11}$ Economistas começaram a cogitar dos efeitos da incerteza e das diferenças de assimilação da informação com os trabalhos de Frank Knight, Friedrich Hayek e, depois, Kenneth Arrow, mas a Economia da Informação se desenvolveu mesmo a partir do trabalho de George Stigler, e depois George Akerlof, Michael Spencer, Joseph Stiglitz e Michael Rothschild, para citar apenas os mais proeminentes estudiosos do tema.
} 


\section{CAPÍTULO 1. A INCERTEZA E O PROCESSO DE ESCOLHA}

\section{Incerteza e Informação}

A discussão do papel da informação que permeia o contrato de seguro pressupõe abordagem do significado da incerteza e suas implicações no processo de escolha, porque a informação é o reverso da incerteza. ${ }^{12}$ Uma é inversamente proporcional à outra. Em sentido objetivo, incerteza retrata falta de informação, desconhecimento das condições em que se atua, embora possa estar relacionada à falha de percepção ou de assimilação da informação, a despeito de sua adequada distribuição ou transmissão. A incerteza se resume, para Hirshleifer, na dispersão das probabilidades subjetivas (ou crenças) de distribuição sobre possíveis estados do mundo. Informação, nesse contexto, consiste em fatos que tendem a mudar essas probabilidades de distribuição ${ }^{13}$. Incerteza é comumente referida como estado de espírito caracterizado pela dúvida baseada na falta de informação a respeito de evento futuro. Nesta acepção subjetiva, traduzida como reação psicológica à imperfeição informacional ${ }^{14}$, ou decorrente da percepção de um risco puro ${ }^{15}$, independe da efetiva existência do risco ou da objetiva imperfeição da informação.

Sua importância se prende à aversão ao risco da maioria das pessoas, que, por isso, se dispõem a pagar um preço predeterminado para afastar ou reduzir a sensação de incerteza $^{16} \mathrm{e}$ as consequências econômicas de eventual perda decorrente da possível efetivação do risco.

A incerteza permeia o processo de tomada de decisões, principalmente em relação àquelas que se projetam no futuro. Excetuadas as trocas imediatas tendo por objeto bens cuja qualidade é constatável ictu occuli, os contratos criam direitos e obrigações a serem cumpridas no futuro, o que os submete à incerteza. Mas se esta é propriedade inerente à escolha projetada para o futuro, não lhe é exclusiva, porque pode referir-se ao

\footnotetext{
${ }^{12} \mathrm{Na}$ sucinta definição de ARROW, “informação é meramente a medida negativa da incerteza”. ARROW, Kenneth J. Information and economic behavior. In: ___ The economics of information. MA: Belknap Press Harvard University, 1984. p. 138. (Collected Papers of Kenneth Arrow, v. 4).

${ }^{13}$ Mas o autor ressalva que a mudança na distribuição de crenças é um processo, não uma condição que constitui a essência da informação. HIRSHLEIFER, Jack. Where are we in the theory of information? The American Economic Review, v. 63, n. 2, p. 31, May, 1973.

${ }^{14}$ VAUGHAN, Emmett J.; VAUGHAN, Therese M. Fundamentals of risk and insurance. $10^{\text {th }}$. ed. New Jersey: John Wiley \& Sons, Inc, 2008. p. 3.

${ }^{15}$ ATHEARN, L.; PRITCHETT, S. Travis; SCHMIT, Joan T. Risk and insurance. $6{ }^{\text {th }}$ ed. MN: West Publishing Company, 1989. p. 6-7.

${ }^{16}$ Id. Ibid., p. 6-7.
} 
desconhecido no presente, conquanto seus efeitos se reflitam no futuro, como a incerteza relacionada à qualidade do produto ou serviço só constatável pela experiência, ou aos atributos da contraparte contratual aptos a afetar a eficiência do contrato.

Embora usados como sinônimos de indefinição em relação a algum evento futuro, incerteza e risco têm significados distintos. Knight criticava o uso ambíguo dos dois termos ${ }^{17}$, sugerindo que se restringisse o termo 'incerteza' aos casos não quantificáveis, sob o argumento de que a mensurabilidade da incerteza compromete sua natureza a tal ponto que nem chega a ser, de fato, incerteza ${ }^{18}$. Justificava a necessidade de adequação do uso do termo 'risco' pela sua conexão com as probabilidades objetivamente mensuráveis do seguro, em oposição às probabilidades subjetivas que caracterizam a incerteza. Salientando as diferenças entre as duas categorias, observava que, em relação ao risco, a distribuição do resultado em um grupo de instâncias é conhecida, ou por cálculo a priori ou pelo método empírico, aplicando-se ao futuro as estatísticas das experiências passadas, enquanto no caso da incerteza, é impossível agrupar instâncias, dada a singularidade da situação tratada ${ }^{19}$.

Daí se extraem três conclusões relevantes em relação ao tema deste trabalho, que são aqui antecipadas para demonstrar a pertinência da abordagem preliminar da incerteza e da informação. A primeira diz respeito à classificação do contrato de seguro como aleatório ou comutativo, aspectos relacionados à incerteza ou ao risco. A segunda, relacionada à primeira, é que a mensurabilidade do risco, essencial ao contrato de seguro, depende basicamente da transmissão à seguradora das informações relevantes em relação ao risco segurado, às quais somente o proponente tem acesso. E a terceira, conexa com as outras duas, é que a redação equivocada da lei ou sua aplicação inadequada poderá afetar a mensurabilidade do risco, transformando-o em incerteza, o que provoca o desequilíbrio do contrato, incentiva o oportunismo, que se traduz por deslealdade na contratação, e gera insegurança jurídica. Estes tópicos serão discutidos com a abordagem das soluções extramercado para o problema da assimetria informacional, como a exigência da máxima boa-fé no contrato de seguro, e, depois, com a análise do risco como elemento do contrato de seguro.

\footnotetext{
${ }^{17}$ KNIGHT, Frank Hyneman. Risk, uncertainty and profit. Londres: Houghton Mifflin Co, 1921. Reimpresso por Nabu Public Domain Reprints, 2001. p. 233.

${ }^{18}$ Id. Ibid., p. 19-20.

${ }^{19}$ Id. Ibid., p. 233.
} 


\section{Informação e Racionalidade Humana}

A racionalidade é premissa subjacente tanto à ciência econômica como à jurídica. $\mathrm{O}$ Direito também a pressupõe ao estabelecer presunções, ao atribuir responsabilidade civil e penal a partir da maioridade, ao definir paradigmas de conduta, cominando sanções aos comportamentos que escapam às balizas estabelecidas e vinculando as partes às suas declarações.

Mas a racionalidade aqui pressuposta não corresponde apenas à capacidade intelectiva. É o que se supõe ser inerente a essa capacidade: a aptidão de adequar os meios disponíveis aos fins pretendidos ${ }^{20}$. Esse nexo de coerência entre meios e fins é o que melhor a caracteriza.

O exercício da racionalidade é geralmente prospectivo, porque analisa fatos conhecidos do passado aplicando as conclusões dessa análise para inferir contingências futuras, o que implica sempre certo grau de incerteza, que lhes é inerente. ${ }^{21}$

A racionalidade humana é condicionada por fatores exógenos, como a incerteza quanto às condições de mercado, à qualidade dos bens objeto das trocas, à disponibilidade e disposição da contraparte para cumprimento do contrato, além de fatores endógenos, como a aptidão intelectiva, as condições psicoemocionais, os valores culturais, éticos, religiosos, que também influenciam as escolhas individuais. A assimilação da informação também depende de quanto o agente a valoriza, pois frequentemente ele nem sequer atina com sua importância no contexto das decisões que está em vias de tomar. As limitações concernem tanto à percepção e assimilação da informação, processadas diferentemente de um indivíduo para outro, como à execução de suas ações ${ }^{22}$, que nem sempre correspondem coerentemente aos seus desígnios ${ }^{23}$.

Não importa quanto a tecnologia de processamento de informação tenha evoluído, a capacidade da mente humana e dos sentidos de absorver informação representará uma

\footnotetext{
${ }^{20}$ FIANI, R. Teoria dos jogos: com aplicações em economia, administração e ciências sociais. 2. ed. rev. e atual. Rio de Janeiro: Campus Elsevier, 2006. p. 21.

${ }^{21}$ KNIGHT, Frank Hyneman. op. cit., p. 201-203.

${ }^{22}$ Id. Ibid., p. 202.

${ }^{23}$ Knight distingue pelo menos cinco elementos variáveis nas capacidades e atributos individuais: (1) diferença quanto à capacidade de percepção e inferência de formar juízos corretos, de interpretar ações humanas e antecipar o futuro; (2) outra diferença está na capacidade dos homens em julgar os meios e discernir e planejar ajustes necessários para corresponder à situação futura antecipada; (3) também varia o poder de executar os planos e ajustes necessários. (4) também difere o comportamento dos indivíduos em situações de incerteza em razão da maior ou menor confiança que sentem em seu julgamento e sua capacidade de execução; (5) e, finalmente, a diferente reação de cada um à incerteza, já que alguns assumirão riscos e outros não. KNIGHT, Frank Hyneman. op. cit., p. 241-242.
} 
limitação permanente. ${ }^{24}$ Por mais denso que seja o bombardeio de informações a que somos submetidos diariamente, não poderemos processar a maioria delas, seja por falta de tempo ou de interesse, seja por inaptidão intelectual. Por conta da nossa racionalidade limitada, pode ocorrer um processo de congestão, pois podemos reter apenas sete dados de uma vez, o que leva a crer que uma boa informação pode estar excluindo outra ${ }^{25}$.

As limitações exógenas à racionalidade se resumem genericamente na incerteza, que corresponde à falta ou à imperfeição de informação. Por isso, não se poderia tratar da informação sem analisar o papel da incerteza no processo de escolha.

Tomando-se a premissa de que, agindo racionalmente, os indivíduos fazem escolhas finalísticas ${ }^{26}$, buscando satisfazer seus interesses a partir de dados conhecidos ou presumidos, é fácil constatar a importância da informação para viabilizar escolhas conscientes, pois essa elaboração mental da decisão não pode prescindir de algum conhecimento das circunstâncias em que ela é tomada.

Analisando o processo psicológico da tomada de decisão, Kahneman e Tversky observaram que envolve duas etapas: a da representação mental do problema e subsunção da situação fática ao quadro criado, e a da avaliação ${ }^{27}$. E quanto mais complexa a situação, mais imperfeita será sua representação e avaliação, assim como quanto melhor for a informação, mais abalizada poderá ser a decisão. Mas, mesmo uma decisão instruída por informação verdadeira e suficiente poderá não ser abalizada, pois o fator da percepção individual varia de uma pessoa para outra. A escolha baseada em presunções sempre implica processo mental e estratégico muito mais elaborado e difícil, e, por isso mesmo, custoso.

Todas as limitações aqui referidas se refletem no processo de escolha, pois a disparidade de informação entre os agentes e as diferentes reações à incerteza e ao risco levam a decisões distintas, porque condicionam a racionalidade humana, sem, contudo, descaracterizá-la pelo fato de condicioná-la.

\footnotetext{
${ }^{24}$ ARROW, Kenneth J. op. cit., p. 145-146.

${ }^{25}$ HIRSHLEIFER, Jack. op. cit.,p. 31-39.

${ }^{26}$ Purposeful choices, na expressão de SCHÄFER, Hans-Bernd; OTT, Claus. The economic analysis of civil law. Massachussets: Edward Elgar Publishing, Inc., 2004. p. 51.

${ }^{27}$ TVERSKY, Amos; KAHNEMAN, Daniel. Prospect theory: an analysis of decision under risk. Econometrica, v. 47, n. 2, p. 263-291, Mar. 1979, e Rational choice and the framing of decisions. The Journal of Business, v. 59, n. 4, Out. 1986. Part 2: The Behavioral Foundations of Economic Theory.
} 


\section{Evolução do Pensamento Econômico e Jurídico Relativo à Informação}

Não se propõe aqui estudo aprofundado deste tema, que escaparia ao âmbito do trabalho, mas uma visão panorâmica das duas linhas evolutivas do pensamento econômico e jurídico em relação à informação, para evidenciar que o paralelismo entre elas não decorre de mera coincidência.

O modelo econômico neoclássico não previa a incerteza nem o risco, e desconsiderava eventual nocividade dos efeitos dos problemas de informação em relação ao processo de escolha. Presumia a racionalidade ilimitada dos agentes, como se todos tivessem a mesma quantidade e qualidade de informação, e a processassem e assimilassem igualmente. Por isso mesmo, o modelo também abstraía os custos de transação, ${ }^{28}$ inclusive os correspondentes à obtenção de informações, supondo que o mercado provia, por meio do sistema de preços, ${ }^{29}$ todos os dados necessários às escolhas dos agentes.

Os principais fundamentos da escola neoclássica eram o comportamento maximizador da utilidade dos agentes econômicos, que ordenam suas preferências de acordo com os próprios interesses, mantendo a estabilidade dessa ordem, e a capacidade de auto-regulação do mercado, que tenderia naturalmente ao equilíbrio. ${ }^{30}$

A percepção dos efeitos da incerteza no processo de tomada de decisão, do desequilíbrio eventualmente criado pela assimetria da informação, pelos custos de

\footnotetext{
${ }^{28}$ Custos de transação correspondem ao tempo e demais recursos despendidos na obtenção de informações atinentes ao negócio entabulado, desde preço e qualidade do produto, até atributos da contraparte aptos a afetar o efetivo cumprimento do contrato, custos investidos na negociação, inclusive a previsão das contingências que podem ocorrer no curso da relação jurídica, recursos despendidos na elaboração e formalização do contrato, no monitoramento do cumprimento do contrato pela contraparte, e, finalmente, na eventual execução forçada do contrato, com todos os seus consectários. Coase demonstra que só na ausência de custos de transação o paradigma neoclássico produziria os resultados alocativos pretendidos, ponderando que essa seria uma suposição utópica e irrealista. Considerando a realidade, em que existem custos de transação, consistentes na busca de informações sobre o outro contratante, sobre o objeto e as condições do negócio, as negociações preliminares até a definitiva formulação do contrato e sua redação, o monitoramento do cumprimento do contrato, que são procedimentos custosos, a alocação de recursos é alterada pela estrutura dos direitos de propriedade. COASE, Ronald. op. cit., p. 114.

${ }^{29}$ Para Arrow, a incerteza não anula, por si só, o papel primário dos preços na alocação de recursos, se existem mercados não apenas para bens, mas também para seguros contra possíveis resultados adversos. Mas admite que a presença de informação, a existência de sinais e a expectativa de sinais futuros implicam que o comportamento econômico seja parcialmente dirigido por variáveis extrapreço. Partindo da premissa de que informação reduz a incerteza, e que os sinais extrapreço têm relevância econômica, constata que vale a pena adquirir e transmitir informações mesmo com algum custo e que a distribuição e assimilação de informação varia de um indivíduo para outro. ARROW, Kenneth J. op. cit., p. 140.

${ }^{30}$ Apesar de algumas críticas à economia neoclássica, Knight também sustentava a tendência natural ao equilíbrio de mercado e, portanto, à concorrência perfeita, e, estabelecendo um paralelo com a física, argumentava que, assim como todo movimento é um progresso em direção ao equilíbrio, as mudanças na economia também tendem ao equilíbrio. KNIGHT, Frank Hyneman. op. cit., p. 17.
} 
transação e a dificuldade de reequilíbrio do mercado nesse contexto, despertaram críticas ao paradigma neoclássico, ${ }^{31}$ demandando certa flexibilização de seus fundamentos.

A influência da incerteza na racionalidade e, consequentemente, no processo de tomada de decisão, demorou a ser reconhecida e considerada na análise econômica, seja porque a reação dos agentes à falta de informação não era facilmente constatável, seja porque a simplificação inerente ao modelo econômico não comportava tal consideração, levando-o a presumir irreal simetria informacional. Pressupondo a onisciência dos agentes, a perfeita observabilidade da conduta da contraparte contratual e a neutralidade ao risco, o modelo econômico afrontava a realidade para não perder o poder de síntese que a simplificação permite, buscando, assim, facilitar a aplicação do paradigma.

Simon $^{32}$ criticou o rigor do conceito neoclássico de racionalidade, que presumia a capacidade do agente de analisar resultados e suas compensações, comparando os pay$o f f s^{33}$, ordenar suas preferências de forma consistente e, ainda, avaliar as probabilidades de cada resultado, se a situação envolvesse incerteza. ${ }^{34}$ Asseverando que não se pode descartar a participação do inconsciente na tomada de decisão, o autor sugeriu simplificações substanciais no processo de escolha, reduzindo as tarefas que incumbem ao agente na tomada de decisão, à escolha entre perda e ganho ou entre satisfatório e insatisfatório, mais compatíveis com a realidade ${ }^{35}$. Mas o exercício de ponderação entre

\footnotetext{
${ }^{31}$ A começar pelo exercício de autocrítica dos próprios filiados à escola neoclássica, como Knight, que não pretendeu desacreditá-la por adotar o modelo teórico simplificado e idealizado da organização competitiva, mas a censurou por não explicitar as limitações do modelo e o caráter aproximativo de suas deduções. Justifica que a economia teórica lida com tendências, ou seja, prevê o que aconteceria em condições simplificadas nunca realizadas, mas sempre relacionadas com a realidade. Partindo do modelo de concorrência perfeita, observa as imperfeições da realidade, e busca estabelecer uma visão sistemática e coerente do que é necessário para aperfeiçoá-la, mas não logra definir quanto e de que forma as condições idealizadas desviam daquelas da vida real e quais correções devem ser feitas para aplicar suas conclusões às situações verdadeiras. KNIGHT, Frank Hyneman. op. cit., p. 5. Mas advertiu que não se pode entender o funcionamento do sistema econômico e o processo de tomada de decisões sem analisar o significado e o papel da incerteza e questionar a natureza e a função da informação. Id. Ibid., p. 199.

${ }^{32}$ Herbert Simon focalizou o aspecto psicológico da racionalidade humana e cunhou o termo bounded rationality, ao apresentar uma concepção mais realista do processo racional de escolha, condicionado pelas limitações inerentes ao gênero humano e pelas circunstâncias do ambiente em que ele atua. Ganhou o prêmio Nobel de Economia em 1978.

${ }^{33} \mathrm{O}$ termo payoff, emprestado da Microeconomia, corresponde ao valor de retorno associado a um possível resultado.

${ }^{34}$ SIMON, Herbert A. A behavioral model of rational choice. The Quarterly Journal of Economics, v. 69, n. 1, p. 103-104, Feb. 1955. Considerando que o tempo, a capacidade cognitiva e de atenção também são recursos escassos, Simon pondera que as escolhas nunca são matematicamente calculadas. Um dos principais problemas é como utilizamos informações imperfeitas e limitada capacidade computacional para lidar com problemas complexos que mal compreendemos. SIMON, Herbert A. Rationality as process and as product of thought. The American Economic Review, v. 68, n. 2, p. 13, May, 1978.

${ }^{35}$ Simon argumenta que já existe "in psychology a substantial body of empirically tested theory about the processes people actually use to make boundedly rational, or 'reasonable' decisions”. SIMON, Herbert. Rationality in psychology and economics. The Journal of Business, v. 59, n. 4, p. 209-224, Oct. 1986. Part 2: The Behavioral Foundations of Economic Theory.
} 
perda e ganho já pode ser considerado como racionalidade do ponto de vista econômico, tanto que Simon admitiu não haver diferença significativa entre a concepção do homo economicus e a das outras ciências sociais. A diferença é que a Economia enfatiza forma especial de racionalidade, o comportamento maximizador, mas esta distinção estaria mais no vocabulário do que na substância, pois o sentido comum de racionalidade adotado pelas demais ciências sociais traduz noção muito semelhante à da racionalidade usada pela Economia. $^{36}$

$\mathrm{O}$ autor sustenta que a análise econômica deveria focalizar mais o processo de escolha do que o resultado desta, para entender como e por que os agentes tomam decisões ${ }^{37}$, e conhecer a influência das limitações que condicionam a racionalidade. ${ }^{38}$

A abordagem do processo racional deveria abranger não só as peculiaridades do agente, mas também as do ambiente em que atua e das inter-relações entre eles, ${ }^{39}$ reconhecendo a influência da estrutura institucional na qual se estabelece a dinâmica da racionalidade. ${ }^{40} \mathrm{O}$ interesse no trabalho de Simon em relação ao tema desenvolvido é a importância que vislumbra no papel das instituições, formais ou informais, e na forma como influenciam o comportamento dos agentes. Isso interessa ao tema porque confirma a função que incumbe às normas sociais e às jurídicas de moldar a interação humana, incentivando comportamentos, que, especialmente no direito contratual, contribuam para melhorar a cooperação entre as partes e o comprometimento com as obrigações convencionadas ${ }^{41}$.

\footnotetext{
${ }^{36}$ SIMON, Herbert A. Rationality as process and as product of thought, cit., p. 5-6.

${ }^{37} \mathrm{~A}$ análise do procedimento racional funciona melhor para explicar a tomada de decisão em circunstâncias complexas e dinâmicas, que envolvem incerteza, exigindo mais da capacidade cognitiva do agente, e são típicas da organização moderna. SIMON, Herbert A. Rationality as process and as product of thought, cit., p. 2. Como o processo racional tem que levar em conta um número muito grande de considerações, somente algumas delas serão conscientes. Por isso, uma teoria de comportamento racional deveria se preocupar tanto com os meios usados pelos agentes para lidar com a incerteza e a complexidade cognitiva quanto com as peculiaridades do ambiente em que as decisões são tomadas. Portanto, importa não apenas a racionalidade substantiva, mas também da racionalidade procedimental, isto é, os procedimentos utilizados para escolher as ações, consideradas as limitações cognitivas humanas. À medida que a Economia reconhece a crescente complexidade cognitiva, mais ela se preocupa com a habilidade dos agentes de lidar com os aspectos procedimentais da racionalidade. Id. Ibid., p. 8-9.

${ }^{38}$ Este enfoque sugerido por Simon complementaria a teoria da racionalidade substantiva. .Substantive Rationality é a expressão usada pelo autor por oposição a Procedural Rationality referida na nota anterior, retrata o exercício de escolha em situações estáticas de menor exigência da capacidade cognitiva. SIMON, Herbert A. Rationality as process and as product of thought, cit., p. 14.

${ }^{39}$ SIMON, Herbert A. A behavioral model of rational choice, cit., p. 100.

${ }^{40}$ SIMON, Herbert A. Rationality as process and as product of thought, cit., p. 3.

${ }^{41}$ Se forem consideradas as observações de Simon em relação à influência das instituições na tomada de decisão dos agentes, a elaboração e a aplicação das leis serão mais eficientes, e se evitarão os efeitos de segunda ordem gerados pelas normas que ensejam interpretações distorcidas e pela aplicação equivocada da lei.
} 
Com a gradativa convicção de que a incerteza provocava alterações relevantes no processo de escolha dos agentes e que isso poderia afetar as conclusões ditadas pelo modelo econômico então adotado, os estudos passaram a levar em conta as dificuldades cognitivas inerentes ao ser humano e a assimetria informacional.

O reconhecimento da importância da informação e dos efeitos da desinformação provocou profunda mudança no pensamento econômico. Essas constatações desafiaram a presunção de que havia um conjunto completo de mercados ${ }^{42}$, bem como da onisciência dos agentes e da ausência de custos de transação.

A teoria jurídica do contrato se desenvolveu paralelamente à linha do pensamento econômico. Resumindo a trajetória histórica do dogma da vontade, Roppo retrata aspectos importantes do desenvolvimento da concepção do contrato, ${ }^{43}$ que deixam entrever a correspondência do processo evolutivo das duas ciências. Como as mudanças institucionais ocorrem concomitante ou sucessivamente nos diversos países que guardam semelhanças entre si, e como as leis de um ordenamento jurídico são frequentemente inspiradas em leis de outros, esses efeitos se irradiam entre eles, embora com nuances diferentes, associadas às idiossincrasias de cada ambiente institucional.

A concepção oitocentista do contrato, como relata Roppo, refletia o contexto sócioeconômico e a ideologia política vigente, que passara da estratificação social rígida do ancien régime à moderna sociedade burguesa de índole liberal. ${ }^{44}$ Sob a égide dos princípios de liberdade e igualdade, os indivíduos já podiam conquistar sua posição na sociedade, independentemente do status ditado pelo nascimento. O Direito acompanhava o modelo político, que passara do protecionismo e da forte ingerência estatal para o ideal liberal do laissez-faire, o qual dava espaço à iniciativa privada e à auto-regulação do

\footnotetext{
${ }^{42}$ Como argumenta Stiglitz, se há assimetria de informação entre os agentes, contratos e mercados não podem ser completos. Essa crítica de Joseph Stiglitz se refere ao modelo de equilíbrio geral concebido por Arrow e Debreu. STIGLITZ, Joseph. The contributions of the economics of information to twentieth century economics. The Quarterly Journal of Economics, v. 115, n. 4, p. 1441-1478, Nov. 2000. Advertiu que, mesmo em pequena quantidade, a imperfeição informacional pode ter um efeito significativo em relação ao equilíbrio dos mercados. ROTHSCHILD, Michael; STIGLITZ, Joseph. Equilibrium in competitive insurance markets: an essay on the economics of imperfect information. The Quarterly Journal of Economics, v. 90, n. 4, p. 629-649, Nov. 1976.

${ }^{43}$ ROPPO, Vincenzo. Il contratto, cit., p. 36-37.

${ }^{44} \mathrm{O}$ Código de Napoleão (1804) ainda refletia uma sociedade predominantemente rural, cuja renda era agrícola, e, por isso, disciplinou o contrato principalmente em função da propriedade imobiliária. Mas já não mais exigia formalismo, salvo como exceção, pois os efeitos jurídicos emanavam da vontade das partes. Esta tendência à informalidade, nascida na Idade Média, com os usos e costumes do comércio, sensíveis às exigências do desenvolvimento comercial e a celeridade da contratação, foi generalizada pelo Código de Napoleão, que aplicou a todos os contratos o princípio que era, até então, exclusivo dos contratos mercantis. GALGANO, Francesco. Il contratto. Verona: Cedam, 2007. p. 2-3.
} 
mercado $^{45}$. O dogma da vontade, formulado pela escola jusnaturalista, que considerava a liberdade de ação e de disposição dos próprios bens um direito natural do ser humano, não se limitava a considerar o contrato como ato de vontade. Sustentava a ideia de domínio da vontade individual, que merece o reconhecimento e a proteção integral do ordenamento jurídico. ${ }^{46} \mathrm{~A}$ ampla liberdade de contratar só comportava alguns limites negativos, que demarcavam as fronteiras dentro das quais o individualismo das partes podia agir plenamente. ${ }^{47}$ E mesmo a imposição de limites negativos destinados a proteger agentes juridicamente vulneráveis, encontrava resistência no regime jurídico contratual. Na aplicação da lei também se impunha a abstenção de interferência na livre escolha dos agentes, pois a justiça contratual decorria automaticamente da concepção do contrato como expressão da liberdade das partes que voluntariamente estabeleciam as regras às quais espontaneamente se submetiam. ${ }^{48}$ A teoria da vontade, como fundamento e substância do contrato, refletia a ideologia então vigente, enfatizando o foco do Direito Contratual direcionado à liberdade de escolha. À luz da teoria, o núcleo do contrato é a vontade criadora do indivíduo, razão pela qual qualquer declaração dissonante da efetiva vontade psíquica seria inidônea a constituir o vínculo contratual, pela falta de seu elemento essencial $^{49}$. A autonomia privada, traduzida pela liberdade dos contratantes de ditarem as próprias regras às quais voluntariamente se vinculam, se baseava, então, na presunção de igualdade e de onisciência das partes e no equilíbrio natural do contrato, o que evidencia a similaridade dessas premissas com os postulados do pensamento econômico da época.

Como contraponto lógico da ampla liberdade de contratar, prevalecia a total responsabilidade das partes pelas obrigações pactuadas e sua estrita aderência aos termos convencionados. Roppo ressalta a indiscutível substância ética e relevante função econômica do princípio pacta sunt servanda, asseverando que o respeito pelas obrigações assumidas é condição para que as trocas e outras operações de circulação de riquezas se desenvolvam de modo correto e eficiente. ${ }^{50} \mathrm{E}$ observa que essa herança liberal, embora submetida a várias revisões, ainda subsiste em larga medida no sistema jurídico atual ${ }^{51}$. Da mesma forma, vigoram até hoje, embora revisadas, muitas das premissas da escola econômica clássica.

\footnotetext{
${ }^{45}$ ROPPO, Vincenzo. Il contratto, cit., p. 37.

${ }^{46}$ BIANCA, Massimo. Diritto civile: il contratto. 2. ed. Milano: Giuffrè, 2000. v. 3, p. 25.

${ }^{47}$ ROPPO, Enzo. O contrato, cit., p. 32.

${ }^{48}$ Id. Ibid., p. 35.

${ }^{49}$ BIANCA, C. Massimo. op. cit., p. 18.

${ }^{50}$ ROPPO, Enzo. O contrato, cit., p. 34.

${ }^{51}$ Id. Ibid., p. 32.
} 
A concepção da irrestrita liberdade contratual foi-se modificando para moldar-se à realidade em mutação. No final do século XIX, a evolução do mercado e o amadurecimento do capitalismo exigiam mais certeza nas relações jurídicas, pois a nova conjuntura econômica não comportava o risco de anulação de contratos por fatores relacionados à esfera psíquica da parte, sob pena de a insegurança jurídica daí decorrente obstar a iniciativa empreendedora. ${ }^{52} \mathrm{~A}$ impugnação do dogma da vontade estava ligada à contestação da própria liberdade da economia. Nas doutrinas alemã e italiana, a teoria objetiva do contrato se inspirou inicialmente na ideologia fascista, que teria sido considerada a antítese da concepção individualista, e que sustentava a concepção do Estado que reconhece a importância da autonomia privada na medida em que esta realiza uma função socialmente útil segundo os fins superiores da nação ${ }^{53}$. Porém, a doutrina objetiva do negócio jurídico abandonou esta inspiração política, e se enquadrou melhor na concepção positivista do sistema jurídico, adotando o critério técnico que impõe o exame da fattispecie, da qual não faz parte a vontade ${ }^{54}$.

A crise do dogma da vontade assinalou, pois, a transição da concepção subjetiva do contrato para uma concepção predominantemente objetiva, adotando a teoria da declaração ${ }^{55}$, que não considera apenas a formação da vontade individual na esfera psíquica do sujeito, mas também sua projeção externa, a forma como ela é transmitida e percebida pela contraparte ${ }^{56}$. O foco da teoria da declaração se desloca, então, da esfera da vontade psíquica do declarante para sua expressão objetiva, tal como exteriorizada para a

\footnotetext{
${ }^{52}$ ROPPO, Enzo. O contrato, cit., p. 38.

${ }^{53}$ Está aí a origem espúria da função social do contrato (art. $421 \mathrm{CC}$ ), cópia extemporânea do Código Civil italiano de 1942, concebido sob influência política do fascismo, que subordinava a eficácia dos negócios jurídicos à utilidade social. O mais curioso é o aspecto obsoleto da inspiração do legislador pátrio, que, mesmo depois da exclusão do Código Civil italiano daquela expressão denunciadora do Estado totalitário, tomou-a desavisadamente como paradigma equivocado de uma suposta solidariedade social, lógica e filosoficamente deslocada no Direito Contratual. E esta inadequação é confirmada pelas intermináveis discussões doutrinárias suscitadas por esta instituição, cujo conceito, função e alcance ainda se desconhecem, dando margem a tantas interpretações antagônicas, o que, por si só, já contraria a função do Direito, que é propiciar a previsibilidade das decisões judiciais, incentivar o comprometimento dos agentes e garantir a segurança jurídica, além de assegurar a liberdade de escolha e de iniciativa, que é fundamento da autonomia privada.

${ }^{54}$ BIANCA, C. Massimo. op. cit., p. 26.

${ }^{55}$ A adoção da teoria da declaração pelo direito positivo partiu da premissa de que o contrato era baseado no fenômeno social, e não no psíquico. À luz do regime jurídico contratual, a declaração vincula o declarante, ainda que sua vontade interior seja diversa da manifestada. A falta de correspondência entre a vontade declarada e a interior não altera a natureza do negócio jurídico, embora conceda ao declarante meios judiciais de impugná-lo. A impugnabilidade do contrato pressupõe que se tenha aperfeiçoado o negócio jurídico independentemente da vontade psíquica do agente. Id. Ibid., p. 20.

${ }^{56} \mathrm{ROPPO}$, Enzo. $O$ contrato, cit., p. 38-39.
} 
contraparte, aperfeiçoando a tutela da informação. Esta objetivação do contrato ${ }^{57}$ enfatiza mais a confiança recíproca do que a liberdade individual dos contratantes, e busca maior segurança jurídica, imputando ao contratante a responsabilidade pela confiança incitada por sua declaração. ${ }^{58}$ A responsabilidade pela confiança criada corresponde à essência do princípio alemão da boa-fé, que se apresenta como a feição institucional mais estreitamente relacionada com a disciplina da informação. ${ }^{60}$

No Brasil também se refletiu o paralelismo apontado, pois o pensamento jurídico acompanhou o processo evolutivo do pensamento econômico, embora em ritmo diverso e com nuances distintas, decorrentes do diferente contexto institucional.

O individualismo representado pela soberania da vontade das partes, a presunção de igualdade entre elas e da onisciência que caracterizava sua racionalidade, constituíam elementos fundamentais da concepção tradicional do contrato adotada pela nossa primeira codificação.

\footnotetext{
${ }^{57}$ Como observa Massimo Bianca, a tendência de objetivação se apresenta em três planos diferentes: primeiro, se traduz pela restrição do papel do acordo de vontades em relação ao significado objetivo da relação (objetivação do contrato); segundo, pela restrição do papel da vontade individual em face da predisposição das cláusulas gerais do contrato (padronização do contrato); e terceiro, pelas crescentes limitações da autonomia privada em face da regulamentação imperativa (publicização do contrato). BIANCA, C. Massimo. op. cit., p. 34-35. O primeiro aspecto retrata a concepção do contrato enquanto fato social cujo significado deve ser determinado por critério objetivo, o que propicia uso crescente de normas interpretativas e integrativas, que não se atêm somente à vontade das partes. O segundo decorre da massificação das relações negociais, que impôs um novo modelo de contratação, mediante predisposição das cláusulas contratuais gerais para servir a um número indeterminado de futuros e eventuais contratantes, que embora tenham poder de barganha mais reduzido, também se beneficiam da redução dos custos da contratação. Esses dois fenômenos respondem a exigências do próprio mercado, e, não afetam a função sócio-econômica do contrato, porque contribuem para garantir mais confiabilidade nas relações jurídicas e reduzir custos de transação, aumentando, com isso a eficiência do contrato como instrumento da livre e voluntária circulação de riquezas. Já o fenômeno da 'publicização', segundo Bianca, "non constituisce uma storia particolare del contratto ma é riflesso del passaggio, ancora in corso, da um ordinamento liberale ad um ordinamento sociale. Come si è visto, non si tratta semplicemente di riscontrare um numero crescente di limitazioni pubblicistiche alla libertà contrattuale, ma di prendere atto della crescente esigenza di subordinare tale libertà all'utilità sociale" (Id. Ibid., p. 35). Esta tendência à 'publicização' do direito privado, que tem contaminado parte da doutrina e, consequentemente, da jurisprudência, reflete o intervencionismo inerente ao estado social, que se contrapõe lógica e ideologicamente à função essencial do contrato como expressão da autonomia privada, que é instrumento do exercício da livre iniciativa, sobre a qual se funda a ordem econômica (art. $170 \mathrm{CF}$ ). Submeter o contrato à utilidade social não apenas limita a liberdade de auto-regulação, mas tende a solapá-la, como ocorre nos regimes totalitários.

${ }^{58}$ Massimo Bianca observa que o princípio da auto-responsabilidade é o contraponto da plena autonomia privada, e implica que quem emite uma declaração, neste contexto, se submete às conseqüências jurídicas daí emanadas, de acordo com seu teor objetivo, podendo responder até por culpa. Este princípio da autoresponsabilidade atribui ao declarante o risco de uma declaração destoante da vontade real e esta alocação do risco contratual se justifica pela proteção da confiança da contraparte, pois a função do direito contratual de tutela da confiança prevalece sobre a de proteção do declarante. Id. Ibid., p. 21-22.

${ }^{59}$ Como pondera Roppo, a cogente vinculação contratual do agente cuja declaração não teria correspondido à efetiva vontade psíquica, seria severo, mas não injusto. ROPPO, Enzo. O contrato, cit., p. 39.

${ }^{60}$ Disso trataremos no capítulo 3, sob a rubrica "Linhas gerais da disciplina da informação nos contratos".
} 
A teoria jurídica não tratava expressamente da falta ou imperfeição da informação, mas apenas implicitamente, e como garantia da autonomia privada, com o objetivo de assegurar às partes o pleno exercício do consentimento, sem vícios que pudessem comprometê-lo ou invalidá-lo. Daí a disciplina do erro e do dolo, como defeitos da declaração da vontade, associados à assimetria de informação na fase pré-contratual, e aptos a acarretar a anulação do contrato, dependendo de fatores relacionados ao pleno exercício do livre convencimento e à consequente legitimidade do consentimento. ${ }^{61}$ Além destes vícios que permitiam a solução legal mais drástica, por implicarem a invalidade do negócio jurídico, a lei já reconhecia o vício redibitório, que enseja, de acordo com as circunstâncias, a redução ou a devolução do preço, eventualmente acrescido de perdas e danos, dependendo da ciência do defeito pelo vendedor.

A teoria da aparência, criada pela doutrina e pela jurisprudência e acolhida pelo Código Civil de 1916, era destinada precipuamente à proteção da boa-fé, mas cuidou implicitamente da disparidade da informação, tutelando a confiança nas relações negociais e a segurança jurídica. ${ }^{62}$

O sistema jurídico trata expressamente da assimetria informacional apenas na abordagem de situações específicas regidas por leis especiais, como, por exemplo, o mercado acionário ${ }^{63}$ e o direito do consumidor. A legislação de caráter geral não identifica os custos de transação gerados por problemas de informação.

O Código Civil de 2002 consagrou a boa-fé e a probidade como padrões de conduta impostos desde a fase de formação do contrato, traduzindo a exigência de lealdade, veracidade e honestidade para tutelar a confiança recíproca. A exigência de boa-fé desde a fase de formação do contrato deixa entrever preocupação com a assimetria informacional, pois boa-fé e informação são estreitamente relacionadas. Mas, como não prescreve

\footnotetext{
${ }^{61}$ Como observa Roppo, "il dogma della volontà porta anche notevoli conseguenze pratiche: qualunque fatto problematico, che tocchi la volontà del contraente, mette in discussione il contratto e suoi effetti." ROPPO, Vincenzo. Il contratto, cit., op. cit., p. 37.

${ }^{62}$ Os vícios do consentimento associados à falha informacional, o vício redibitório e a teoria da aparência serão examinados mais detalhadamente no capítulo seguinte.

${ }^{63}$ A Lei 6.404 de 15 de dezembro de 1976, que rege as sociedades por ações, estabelece expressamente o dever de informar do administrador da companhia aberta no art. 157 e seus parágrafos, especialmente no $\S$ $4^{\text {o }}$, que impõe o dever de comunicar à Bolsa de Valores e de divulgar ao público em geral fato relevante concernente à companhia. Relevante é considerado o fato que pode influir no processo de tomada de decisão do mercado investidor, em relação à compra ou venda de valores mobiliários da companhia. $\mathrm{O}$ art. $155, \S 1^{\circ}$, que prevê o dever de lealdade do administrador, também trata de elidir os efeitos nocivos da assimetria informacional, ao proibir o uso indevido de informação privilegiada (insider information), a que o agente tem acesso em razão do exercício profissional e em função do cargo que ocupa, para obter para si ou para outrem, vantagem mediante compra ou venda de valores mobiliários (insider trading).
} 
expressamente o dever de informar, restringindo-se a estabelecer padrão genérico de comportamento, traduzido por uma expressão plurívoca, a lei civil pouco contribui, neste contexto, para eficiência do Direito como instrumento regulatório, e para a certeza jurídica, como se demonstrará oportunamente na abordagem específica da disciplina da informação no direito contratual.

O progresso tecnológico e o desenvolvimento econômico viabilizaram a produção em larga escala, que, atendendo à demanda do consumo de massa e favorecendo a redução dos custos de produção, propiciaram também a concepção de um novo modelo de contratação, por meio da predeterminação das cláusulas gerais do contrato, caracterizadas pela generalidade, impessoalidade e uniformidade. Essa padronização confere maior rapidez à contratação e reduz custos de transação em relação aos contratos costumizados, ${ }^{64}$ favorecendo, por isso, ambas as partes, mas contraria a presunção da igualdade dos contratantes, pois o contrato pré-moldado é desenhado pelo predisponente em função de seu interesse, o que reduz o poder negocial da contraparte.

Reconhecendo a potencial desigualdade das partes, o Código de Defesa do Consumidor aponta a vulnerabilidade deste, para atribuir-lhe especial proteção com a finalidade de reduzir o desequilíbrio entre as partes. ${ }^{65}$ Tratou da propaganda como informação apta a afetar a legitimidade do consentimento do consumidor, erigindo a publicidade enganosa à categoria de ilícito penal, e tipificando condutas como a declaração falsa e a omissão de informação relevante sobre a natureza, característica, qualidade, quantidade, segurança, desempenho, durabilidade, preço ou garantia de produtos ou serviços.

A despeito da crescente tendência ao reconhecimento da eventual nocividade da disparidade de informação, há presunções que se mantêm fiéis à tradição, como a da ciência da lei por todos os cidadãos, aos quais é vedada a alegação de desconhecê-la ${ }^{66}$. Apesar da incontestável irrealidade dessa presunção, sua manutenção se deve à eficiência que proporciona à aplicação das normas, não permitindo o oportunismo dos agentes para eventualmente escaparem às sanções. Admitir a alegação de ignorância da lei subtrairia

\footnotetext{
${ }^{64}$ Neologismo que está se incorporando à língua culta para significar feitos um a um, sob medida.

${ }^{65} \mathrm{~A}$ vulnerabilidade do consumidor reconhecida no art. $4^{\circ}$, I, da L. 8078/90, tem sido equivocadamente entendida como hipossuficiência econômica, conceito inapto a traduzir o real conteúdo da vulnerabilidade, que compreende o reduzido poder de barganha e a falta de informação. Ressalve-se, porém, que a assimetria informacional não afeta apenas o consumidor, mas pode afetar mais severamente o fornecedor, como se demonstrará na discussão dos efeitos da disparidade de informação no contrato de seguro, inclusive nas hipóteses em que se classifica como relação de consumo.

${ }^{66}$ Esta tradição se mantém desde o direito romano: Ignorantia legis neminem excusat.
} 
todo o poder coercitivo do ordenamento jurídico, prejudicando tanto a sua função de punir como a de incentivar comportamentos. Equiparar a informação disponível a respeito das leis, a partir de sua publicação e vigência, à efetiva apreensão de tais dados pelos indivíduos, apesar da distância que separa essas duas situações, é uma forma eficiente de tratar a informação, desconsiderando as limitações da racionalidade dos agentes para atribuir-lhes efetiva responsabilidade por seus atos.

O Código Civil também presume a ciência do agente, ou desconsidera a priori sua ignorância, em situações em que o acolhimento da alegação de desconhecimento obviaria a aplicação da sanção cominada ${ }^{67}$.

Em suma, o Direito também estabelece presunções em prol da eficiência de sua aplicação e a evolução paralela da teoria jurídica do contrato e da teoria econômica reflete a mutação do contexto sócio-político, cultural e econômico, pois ambas são ciências aplicadas a essa mesma realidade.

\section{A Natureza da Informação}

Discutir a assimetria informacional pressupõe a compreensão das peculiaridades inerentes à informação, as quais lhe atribuem um caráter diferente dos demais bens.

Quando está dispersa, como geralmente se apresenta, tem as mesmas características dos bens públicos, no sentido econômico do termo: não-rivalidade, porque seu uso não diminui a utilidade para os demais usuários, e não-excludência, porque também não impede o uso concomitante por outros.

Sua produção é quase sempre dispendiosa, e a transmissão muito fácil, o que torna difícil a apropriação da renda por ela gerada, assim como seu controle ${ }^{68}$, permitindo o

\footnotetext{
${ }^{67}$ É o caso, por exemplo, da anulação de negócio jurídico por dolo de terceiro, se a parte a quem aproveite dele tivesse ou devesse ter conhecimento (art. 148), da responsabilização do administrador de sociedade que realiza operações, sabendo ou devendo saber que estava agindo em desacordo com a maioria (art. $\left.1.013, \S 2^{\mathrm{o}}\right)$.

${ }^{68} \mathrm{~A}$ informação não é apropriável porque um indivíduo que a tenha não irá perdê-la quando a transmite. É frequentemente notado em conexão com a economia de pesquisa e desenvolvimento que a informação adquirida, a um alto custo, através de pesquisa pode ser transmitida muito mais barata. Se a informação for transmitida para um comprador, ele pode vendê-la por um preço mais baixo, de forma que os preços do mercado fiquem bem abaixo do custo de produção. Mas se os custos de transmissão forem altos, então também é verdade que não será apropriável, já que o vendedor não pode perceber o valor social da informação. Ambos os casos ocorrem na prática com tipos diferentes de informação. ARROW, Kenneth J. op. cit., p. 142.
} 
efeito carona (free rider). Como observou Arrow ${ }^{69}$, o paradoxo da informação é que o comprador não pode aquilatar seu valor antes de adquiri-la, mas depois de obtê-la, já terá usufruído dela sem pagar, o que lhe tira a disposição de comprá-la ${ }^{70}$.

Essas peculiaridades da informação, como a indivisibilidade de uso e a dificuldade de apropriação, impedem que seja representada no modelo abstrato de equilíbrio geral, desafiando a presunção de que o livre mercado levará automaticamente a uma alocação eficiente de recursos. $^{71}$

Devido à sua natureza sui generis, a informação, embora suscetível de apropriação, comporta tratamento diferente dos outros bens.

Figura como objeto dos contratos de propriedade intelectual, mas também desempenha papel relevante nos negócios jurídicos em geral, especialmente quando concerne ao objeto do contrato ou aos atributos das partes em relação ao cumprimento das obrigações. Esta é a configuração que está no foco deste trabalho, que se propõe a demonstrar a importância da informação nas relações contratuais. Quando é relevante e essencial em relação aos contratos, interessa muito ao mercado, e consequentemente à sociedade, e ao Direito.

\section{A função e a importância da informação que instrui o contrato}

Como assinalou George Stigler, cujo trabalho foi um marco inaugural na teoria da informação ${ }^{72}$, ninguém precisa dizer para os acadêmicos que informação é um recurso valioso: conhecimento é poder ${ }^{73}$.

\footnotetext{
${ }^{69}$ ARROW, Kenneth J. The essays in the theory of risk bearing. Chicago: Markham, 1971. p. 152.

${ }^{70}$ Hirshleifer critica a literatura econômica sobre pesquisa e invenção, que sustenta haver uma tendência de subinvestimentos privados na atividade inventiva, em razão das imperfeições relacionadas à apropriação da informação. Assevera que essa literatura desconsidera que, além dos benefícios tecnológicos capturáveis pelo inventor, haverá efeitos pecuniários (distribuição de riqueza devido às reavaliações de preços) com a revelação de novas informações. O inovador, primeiro no campo da informação, é capaz de se apropriar, através da revenda ou especulação de informação, de uma porção desses efeitos pecuniários. Esse fato é socialmente útil para motivar a divulgação da informação. HIRSHLEIFER, Jack. The Private and social value of information and the reward to inventive activity. The American Economic Review, v. 61, n. 4 p. 561-574, Sep., 1971.

${ }^{71}$ Como admite o próprio mentor da teoria do equilíbrio, ARROW, Kenneth J. Information and economic behavior, cit., p. 142.

${ }^{72}$ Anteriormente Frank Knight e Friedrich von Hayek tinham focalizado o tema, mas Stigler, discípulo de Knight, delineou seus contornos de uma nova perspectiva, inaugurando a teoria da informação em STIGLER, George J. The economics of information. The Journal of Political Economy, v. 69, n. 3, p. 213-225, Jun. 1961.

${ }^{73}$ Conhecimento permite aos agentes antever os problemas e equacioná-los com mais chances de sucesso. Stigler acrescenta jocosamente, numa de suas expressivas metáforas, que a informação, "apesar disso, ocupa um barraco na cidade da economia". A preciosa contribuição de Stigler lhe rendeu um prêmio Nobel em 1982. Seu artigo aqui referido teve uma importância fundamental na economia da informação. STIGLER, George J. op. cit., p. 213-225.
} 
Conhecimento não é sinônimo de informação, embora muitas vezes os termos sejam usados na mesma acepção, deduzindo-se do contexto o sentido em que foi empregado. A informação, mesmo quando útil, só se transformará em conhecimento, depois de processada pelo receptor, que a assimila e classifica, atribuindo-lhe valor de acordo com as limitações endógenas e exógenas da racionalidade do agente. A mera transmissão de dados informativos não importa a formação do conhecimento, pois este depende da efetiva apreensão, por meio do processo de assimilação pelo agente ao qual é dirigida. Portanto, o acúmulo desordenado de informações não se traduz em conhecimento $^{74}$.

O conhecimento exige a ação cooperativa dos membros da sociedade, porque resulta de processo dinâmico, sujeito a mecanismos de seleção e evolução, não só pela sua relevância conceitual, econômica ou social, mas também a forma como é gerada, distribuída e usada. A manutenção do conhecimento depende da participação dos agentes interessados em acessá-lo. Se não for usado, o conhecimento desaparece, mesmo que tenha sido armazenado em livros, revistas ou meio eletrônico.

Conhecimento pode assumir várias acepções, mas a que nos interessa aqui é a que corresponde ao conjunto de informações já percebidas e introjetadas pelo agente, ou seja, a apreensão de um objeto material ou imaterial pelo pensamento. Nesse sentido, a principal característica distintiva entre conhecimento e informação é a apropriação de dados informativos pelo agente.

Em relação ao contrato, conhecimento aumenta o poder de negociação, pois o contratante que o detém, pode usufruir da vantagem que isso lhe dá, em detrimento da parte menos informada, cuja vulnerabilidade frequentemente decorre da assimetria informacional.

A troca de informações entre as partes opera como indutor de comprometimento e estímulo à cooperação desde a fase pré-contratual, como observam Cooter e Ulen ${ }^{75}$. Mas, mais do que isso, a informação serve para definir o objeto e as condições da contratação, e

\footnotetext{
${ }^{74} \mathrm{O}$ bombardeio de informações a que somos diariamente submetidos evidencia que vivemos na era da informação, mas não necessariamente do conhecimento. A maior quantidade de informação geralmente não reverte em benefício do conhecimento, primeiro, porque a quantidade nem sempre se equipara à qualidade, porque nem todos os dados são úteis; e segundo, porque, mesmo que úteis, os dados precisam ser processados e categorizados, numa escala valorativa, e esse processamento é custoso e eventualmente impossível, dadas as limitações da racionalidade humana.

${ }^{75}$ COOTER, R.; ULEN, T. op. cit., p. 200.
} 
até legitimar o consentimento, que pode não ser válido se uma das partes tiver percepção diferente da natureza do negócio jurídico ou do seu objeto ${ }^{76}$.

Ao tratar da teoria dos custos de transação envolvidos nas trocas econômicas, Douglass North afirma que "obtemos utilidade dos diversos atributos dos produtos e serviços, ou, no caso do desempenho de um agente, das várias atividades que integram sua performance. (...) O valor de uma troca para as partes é o valor dos diferentes atributos ínsitos no produto ou serviço". Depois conclui que "isso exige recursos para avaliar esses atributos e mais recursos para definir e avaliar os direitos objeto da troca". ${ }^{77}$

Se o valor das trocas econômicas equivale ao dos atributos de seu objeto, como sustenta North, as informações a este pertinentes se confundem com seus atributos, e passam a integrar-lhe o núcleo. Informação é tanto o ato como o efeito de informar. ${ }^{78} \mathrm{Na}$ primeira acepção, a informação é abstrata, mas os dados informados, se pertinentes ao objeto do contrato, se consubstanciam nos seus atributos. Portanto, podemos concluir que a informação essencial concernente ao objeto do contrato também é objeto deste, justamente por integrar sua essência ${ }^{79}$. Pode-se dizer o mesmo em relação à omissão de informação essencial ao objeto do contrato, pois contribuindo para construir a representação desse objeto, passa a integrá-lo como atributo seu, porque o que se cala também se fala, ou seja, o silêncio também comunica.

\footnotetext{
${ }^{76}$ Daí a sanção cominada pelo Código do Consumidor à propaganda enganosa, que é a informação total ou parcialmente falsa, que, mesmo por omissão, possa induzir em erro o consumidor a respeito de dados do produto ou serviço. Essa figura se identifica com o dolo, vício do consentimento apto a invalidar o negócio jurídico ou ensejar perdas e danos, como se verá adiante. A disciplina jurídica da publicidade decorre do fato de que as informações nela contidas a respeito do produto ou serviço integram a oferta e, como tal, condicionam a aceitação do consumidor, o que corrobora a ideia de que a informação essencial é pertinente ao objeto do contrato. Ao aderir em bloco às condições gerais do contrato predispostas pelo fornecedor, o aderente leva em conta os atributos propagados em relação ao produto, não só porque são mais inteligíveis e fáceis de assimilar do que o teor de um contrato, mas também porque pode não existir instrumento escrito ou se existir, o consumidor frequentemente opta por não lê-lo. Afinal, a leitura também representa custo de oportunidade, pois o tempo respectivo poderia ser usado para uma atividade mais prazerosa. STIGLER, George J. op. cit., p. 213-225.

${ }^{77}$ NORTH, Douglas. op. cit., p. $28-29$.

78،"Informação significa tanto o processo de formulação e transmissão de atos cognoscíveis, como os próprios dados transmitidos como resultado desse processo." TOMASETTI JUNIOR, Alcides. O objetivo de transparência e o regime jurídico dos deveres e riscos de informação nas declarações negociais para consumo. In: NERY JR., Nelson; NERY, Rosa Maria de Andrade (Orgs.). Doutrinas essenciais: responsabilidade civil: direito das obrigações e direito negocial. 2. tir. São Paulo: Ed. Revista dos Tribunais, 2010. v. 2, p. 69.

${ }^{79}$ Salientando a importância da informação, Knight argumentava que "se determinado nome numa caneta tinteiro ou numa lamina de barbear faz com que esses produtos sejam vendidos por $50 \%$ a mais do que o mesmo produto sem essa informação, então o nome representa uma grande parte da utilidade do produto, e tem a mesma natureza de sua cor ou seu design ou da qualidade de sua pena ou sua navalha, ou qualquer outro atributo que o torne útil ou atraente". Portanto, pode-se dizer que esse bem imaterial (a marca) nada mais é que informação qualificada, já que a grife comunica a reputação do fabricante. KNIGHT, Frank Hyneman. op. cit., p. 262.
} 
Por isso é que, dependendo da relevância da informação, sua omissão ou distorção poderá induzir a erro essencial sobre o objeto do contrato ou a respeito da parte contratante, assim como sua ocultação também viciará o negócio jurídico, com as consequências daí decorrentes ${ }^{80}$.

A informação concernente às condições e ao objeto do contrato ou aos atributos da contraparte nem sempre são acessíveis ao agente, mas ele se disporá a adquiri-la, investindo recursos até o limite da utilidade que ela lhe traria, de acordo com sua expectativa.

\section{Os custos da informação}

Quando se fala em custos da informação subentendem-se os da desinformação. Portanto, não se trata apenas do custo da obtenção da informação, mas também do das consequências de não tê-la, que devem ser ponderados com o custo de adquiri-la.

Contratar implica custos. A falta ou a imperfeição de informação sobre o produto ou serviço objeto do contrato, a dificuldade de prospecção de preços no mercado, o desconhecimento dos procedimentos de pós-venda, da situação econômico-financeira do outro contratante e de sua capacidade ou disposição de cumprir o contrato representam custos de transação.

A pesquisa de preços na fase pré-contratual foi analisada por $\operatorname{Stigler}^{81}$, que salientou a importante função da informação na vida econômica. Apontou a dispersão de preços como índice de ignorância no mercado, observando que a dificuldade do processo de prospecção é agravada pelo dinamismo inerente à informação, o que torna a pesquisa mais custosa. A dinâmica deste processo se deve ao fato de que o conhecimento se torna obsoleto à medida que varia o contexto da pesquisa, como as condições da oferta e da demanda, que mudam com o tempo. Isso provoca a busca por mais informação, e assim por diante, num moto contínuo. Há um componente de ignorância devido à mudança de identidade dos compradores, o que torna obsoleta a informação mantida pela experiência.

\footnotetext{
${ }^{80}$ Esta matéria será tratada com a abordagem genérica e resumida da disciplina da informação no direito contratual, e mais especificamente, em relação ao contrato de seguro.

${ }^{81}$ Stigler apontou a contribuição de fatores endógenos e exógenos para a necessidade de contínua busca de informação, mostrando a dificuldade de se alcançar o equilíbrio sob tais circunstâncias. STIGLER, George J. op. cit., p. 214-220.
} 
A obsolescência do conhecimento decorre também da dimensão do mercado e de outros fatores do ambiente, como a alteração ou a inserção de novos produtos. Ele prognosticou corretamente que, com o crescimento do mercado, surgiriam empresas especializadas em coletar e vender informação, acrescentando que, como o custo da coleta de informações é independente de seu uso, o mercado tenderia a criar um monopólio para provisão de informação comercial.

Stigler aplicou a teoria da escolha racional à incerteza quanto ao preço; Akerlof examinaria, dez anos depois, o mesmo processo em relação à qualidade dos produtos, mostrando que a assimetria informacional gera custos, que, no limite, podem provocar a eliminação dos bons produtos de determinado mercado ${ }^{82}$.

O custo da pesquisa de preço e qualidade de produtos inclui custos materiais e de oportunidade, que corresponde ao tempo gasto nessa atividade e que poderia ter sido destinado a outra ${ }^{83}$. Pode-se dizer que quanto mais fácil for o acesso do agente às informações, menos ele gastará com a pesquisa e mais ela lhe renderá, e, por outro lado, quanto mais valioso for seu tempo, ou seja, quanto mais alto for seu custo de oportunidade, menos pesquisa fará. Tudo se resume, pois, no balanço da relação custo-benefício. Simon observa que a questão não é como, mas quanto se busca de informação, pois isto depende do custo, concluindo que o investimento em pesquisa é determinado pelo mesmo princípio marginal como o investimento em qualquer outro fator ${ }^{84}$.

O custo da incerteza não afeta apenas o consumidor, como leva a supor a legislação destinada à sua defesa, e fundada na sua vulnerabilidade, decorrente da assimetria de informação e do menor poder de barganha.

\footnotetext{
${ }^{82}$ AKERLOF, George. The market for 'lemons': quality uncertainty and the market mechanism. The Quarterly Journal of Economics, v. 84, n. 3, p. 488-500, Aug 1970.

${ }^{83}$ Custos de oportunidade correspondem a tudo aquilo de que se abre mão para poder obter alguma coisa. $\mathrm{O}$ verdadeiro custo de um bem não é apenas a quantia em dinheiro que pagamos por ele, mas tudo o mais, além do dinheiro, que seria, de qualquer forma, sacrificado para sua compra. Esse custo está associado a uma oportunidade perdida, daí sua denominação. Os economistas acreditam que os custos de oportunidade são crescentes na fronteira das possibilidades de produção, porque produzir mais de determinado item, implica produzir menos de outro. KRUGMAN, Paul; WELLS, Robin. Introdução à economia. Rio de Janeiro: Campos Elsevier, 2007. P. 19-21.

${ }^{84}$ Referindo-se à busca de informações, Simon assevera que "the question is not how the search is carried out, but how it is decided when to terminate it, that is, the amount of search. The question is answered by postulating a cost that increases with the total amount of search. In an optimizing model, the correct point of termination is found by equating the marginal cost of search with the (expected) marginal improvement in the set of alternatives. In a satisficing model, search terminates when the best offer exceeds an aspiration level that itself adjusts gradually to the value of the offers received so far. In both cases, search becomes just another factor of production, and investment in search is determined by the same marginal principle as investment in any other factor". SIMON, Herbert A. Rationality as process and as product of thought, cit., p. 1-16.
} 
O fornecedor também sofre os efeitos da incerteza, ao tomar decisões em relação a tudo que concerne à sua permanência no mercado, desde o lançamento ou aprimoramento de produto, à negociação com outros fornecedores, ao estabelecimento do preço, à distribuição, à predisposição de condições gerais, em suma, a todo aquele feixe de contratos que resume a atividade empresarial. Mas isso faz parte dos riscos da empresa, em relação aos quais a incerteza geralmente pode ser mensurada, comportando, pois, previsão. E o que pode ser previsto pode ser administrado. Pior é a incerteza atinente à recuperação de seus créditos, pois quando não é espontâneo o cumprimento dos contratos, sua execução judicial é lenta e custosa e o resultado, incerto. Também afeta demais os agentes a incerteza concernente à interpretação e aplicação da lei em relação à apreciação judicial de contratos. Essas incertezas, imensuráveis e imprevisíveis, não podem ser administradas nem reduzidas pelas organizações, pois dependem da participação efetiva e eficiente das instituições. Nociva também é a falta ou distorção de informações relativas ao objeto do contrato ou aos atributos da contraparte, quando sua causa não é atalhada pela lei e seus efeitos são mal compreendidos pelos intérpretes na aplicação do Direito, como tem ocorrido com lamentável frequência na apreciação judicial dos contratos de seguro ${ }^{85}$.

Dadas as limitações da racionalidade dos agentes, e os custos da obtenção de informações e de previsão de todas as contingências que podem ocorrer no curso da execução contratual, a incerteza também acarreta lacunas nos contratos, que serão eventualmente preenchidas pelo Poder Judiciário. Portanto, esse custo da desinformação abrange o custo do uso do Judiciário, como instrumento de coerção ao cumprimento dos contratos e de complementação de lacunas contratuais ${ }^{86}$.

Em suma, as imperfeições de informação representam custo elevado e acarretam a vulnerabilidade dos agentes.

Essa deficiência informacional, relacionada à impossibilidade de acompanhar as ações da contraparte ${ }^{87}$, na vigência de um contrato de execução diferida, torna vulneráveis todos os agentes mal informados, porque permite o oportunismo da contraparte, e também representa custos difíceis de mensurar.

\footnotetext{
${ }^{85}$ Como se verá, no tópico pertinente, até a doutrina tem eventualmente concorrido para tais equívocos exegéticos. A gravidade de tais interpretações é que a nocividade dos efeitos da assimetria informacional não se restringe somente ao fornecedor, mas se irradia para o mercado.

${ }^{86} \mathrm{~A}$ necessidade de complementação de lacunas decorre não só da disparidade de informação entre os contratantes, mas da incompletude inerente ao contrato, pois geralmente é impossível prever todas as mudanças do estado de fato, e, ainda que se possam prevê-las e mensurá-las, o custo da proposição de soluções será tão elevado que inviabilizará a operação.

${ }^{87}$ Este efeito da assimetria informacional será examinado no próximo capítulo.
} 
A assimetria informacional inerente às atividades do mercado financeiro provoca efeitos que acarretam custo muito elevado representado pelo risco de crédito, que, se disseminado, se tornará sistêmico. O custo, neste caso, extrapola a esfera contratual, atingindo toda a sociedade.

O Direito pode e deve atuar para aplainar a disparidade de informação e reduzir as possibilidades de comportamento oportunista eventualmente adotado pelos consumidores em prejuízo do fornecedor. E aqui não se cogita da proteção deste ou daquele agente econômico, mas de toda a coletividade, que é afetada pelos custos gerados aos fornecedores, por força das consequências daí decorrentes.

O custo da busca de informações e os demais custos da negociação compõem o preço, que é elemento de todo contrato sinalagmático. Como um dos objetivos do direito contratual é a redução dos custos de transação, deve levá-los em conta tanto na prescrição como na aplicação da lei. Os agentes coordenam suas ações no mercado por meio de contratos. Como essas 'transações' têm custos, leis que os atenuem promovem melhor desempenho econômico, maximizando o bem-estar social. Mas não basta que a lei se destine a incentivar a cooperação e comprometimento, reduzir custos de transação, elidir o oportunismo, cumprindo os objetivos do direito contratual, é preciso que sua aplicação acompanhe o mesmo foco.

Stigler constata que, apesar da importância da informação, seus custos nem sempre recomendam regulação exigente demais, tendente a eliminar totalmente a ignorância do mercado, primeiro porque certa dose de incerteza e risco é inerente às relações humanas, no caso, contratuais, e segundo, porque seria totalmente antieconômico pretender reduzi-la ao mínimo ou extirpá-la ${ }^{88}$.

O erro de regulação, seja na prescrição ou na aplicação da lei, custará muito a toda a sociedade, dado o incentivo que representará à prática de condutas oportunistas, como se demonstrará na abordagem da disciplina jurídica da informação no contrato de seguro.

Mas antes de abordar as instituições legais relacionadas às consequências nocivas da desinformação, trataremos das soluções extramercado concebidas para aplainar a assimetria informacional ou reduzir o impacto de seus efeitos.

${ }^{88}$ STIGLER, George J. op. cit., p. 225. 


\section{CAPÍTULO 2. A ASSIMETRIA INFORMACIONAL E INSTITUIÇÕES: SOLUÇÕES DE MERCADO}

\section{A distribuição de informação entre os agentes}

A dispersão da informação e a desigualdade de sua distribuição entre os agentes, que a assimilam de acordo com seus próprios valores e a processam conforme suas limitações, implicam que a incerteza não é igual para todos. Depende de como a informação é distribuída e de como é processada pelo receptor.

Considera-se pública quando é de conhecimento geral, e privada, quando possuída por um agente em particular.

A informação pode servir de subsídio para a tomada de decisão dos contratantes, funcionando como indutor de trocas econômicas, pois quem souber como obter mais rendimento de um recurso do que seu proprietário, tentará adquiri-lo. Quando a informação privada gera eficiência, sua ocultação é perfeitamente aceitável. ${ }^{89}$ Neste caso, não é um problema, mas a solução, pois constitui o móvel legítimo da contratação. ${ }^{90}$ Portanto, em prol da ponderação que deve orientar a regulação. A disparidade de informação que permeia a relação contratual nem sempre constitui imperfeição a ser sanada por soluções externas ao mercado. ${ }^{91}$

Nos contratos, que são trocas voluntárias, os bens tendem a ser transferidos de quem os valoriza menos para quem os valoriza mais, e isso geralmente decorre de um contratante ter mais informações que o outro, em relação ao potencial acordo. Este é um dos aspectos do valor do conhecimento. Por isso, a assimetria informacional nem sempre traz efeitos nocivos à economia e o dever de informar não deve assumir caráter absoluto.

\footnotetext{
${ }^{89}$ COOTER, R.; ULEN, T. op. cit., p. 279-280.

${ }^{90}$ MACKAAY e ROUSSEAU também sustentam que "L'asymétrie n'est pas en soi une raison de craindre que le contrat conclu en ces circonstances ne puisse réaliser un gain de Pareto. Souvent l'échange contractuel est justement recherché en raison des différences de connaissance, de talent ou de valorisation chez les contractants. Dans la vie courante, on fait affaire à des spécialistes en raison de leur plus grande expertise sur un point ou dans un domaine donné. L'asymétrie est ici la raison d'être du contrat." MACKAAY, Ejan; ROUSSEAU, Stéphane. Analyse économique du droit. 2. ed. Paris: Dalloz, 2008. p. 368.

${ }^{91}$ Para falta ou imperfeição de informação como falha de mercado, cf. PINDYCK, Robert S.; RUBINFELD, Daniel L. Microeconomia. Trad. Eleutério Prado e Thelma Guimarães. 6. ed. São Paulo: Pearson, 2006. p. 523-525; e VARIAN, Hal R. Microeconomia: princípios básicos - uma abordagem moderna. Trad. da 7. ed. Trad. Maria J. Cyhlar Monteiro e Ricardo Doninelli. Rio de Janeiro: Elsevier, 2006. p. 747.
} 
A distribuição desigual cria incentivos para a aquisição de informação ${ }^{92}$, e enseja a emissão de sinais para transmitir informação sobre o produto ofertado, criando um mercado para isso ${ }^{93}$.

A disparidade de informação será nociva, porém, quando a parte mais bem informada se prevalecer dessa situação para apropriar- se indevidamente dos ganhos a que a contraparte faria jus em razão do contrato ${ }^{94}$. Quando a assimetria gera efeitos nocivos e não pode ser reduzida ou sanada pelos próprios agentes, ou só poderia sê-lo a um custo elevado, o que geraria ineficiência e retração do mercado, ela comporta correção.

A questão é distinguir em que circunstâncias a assimetria informacional deve ser incentivada ou tolerada, e em que casos ela representa nocividade não solucionável via mercado, e deve ser corrigida, impondo-se o dever de informar, cuja violação, dependendo da relevância da informação omitida ou distorcida, pode dar ensejo à anulação do contrato e eventual reparação.

O problema, que está na raiz de toda regulação, é exatamente saber quando e quanto regular. Porque a regulação mal dirigida ou mal dosada pode causar ainda mais desequilíbrio do que a disfunção que se pretende sanar.

A incompletude dos contratos decorrente da falta de informação nem sempre é ineficiente, pois os custos de obtenção da informação completa, quando esta é possível, podem ser tais que não compensem os benefícios eventualmente auferidos. Como os agentes geralmente avaliam suas ações, ainda que intuitivamente, com base na relação custo-benefício, aí incluídos os custos de oportunidade, há um grau ótimo de incompletude de informação, ${ }^{95}$ eventualmente mais estratégica do que a obtenção da informação a qualquer preço. Stigler sugere tal ponderação entre custo e benefício, na formulação da sua teoria da informação. ${ }^{96}$ Arrow também traça esse paralelo entre a necessidade da informação e a conveniência de obtê-la, concluindo que o gasto de tempo e de outros

\footnotetext{
${ }^{92}$ Informação sobre o comportamento de outros agentes econômicos, especialmente clientes e trabalhadores, ou sobre os preços futuros ou mesmo presentes ou a qualidade dos bens são exemplos mais diretos de informação cuja aquisição é tanto possível quanto desejável. ARROW, Kenneth J. Information and economic behavior, cit., p. 141.

${ }^{93} \mathrm{~A}$ propaganda é o melhor exemplo, embora sua função não se restrinja a isso, como veremos ao analisarmos as soluções de mercado para reduzir a disparidade de informação. Id. Ibid., p. 143-144.

${ }^{94}$ Macho-Stadler e Perez-Castrillo afirmam que a assimetria informacional só tem potencial de nocividade quando existe conflito de interesses. MACHO-STADLER, Ines; PEREZ-CASTRILLO, J. David. An introduction to the economics of information: incentives and contracts. London: Oxford University Press, 1997.

${ }^{95}$ Definido como 'ignorância racional' por Fernando ARAÚJO, que aborda o tema em Teoria económica do contrato. Coimbra: Almedina, 2007. p. 281.

${ }^{96}$ STIGLER, George J. op. cit., p. 213-225.
} 
recursos escassos induziria o consumidor ou outro agente econômico a fazer sua escolha independentemente de não ter informação suficiente ${ }^{97}$. Muito antes, Knight já reconhecia que, embora a conduta racional buscasse reduzir ao máximo a incerteza, no processo de adaptação dos meios aos fins, eventualmente não pretendia eliminá-la ${ }^{98}$, conquanto ele não tivesse cogitado de outra razão para isso, além da impossibilidade material de se abolirem completamente as contingências inerentes ao futuro.

O problema do conhecimento econômico, segundo Hayek, está relacionado ao método da assimilação das informações pelos indivíduos e à sua distribuição desigual entre os agentes. O cerne da questão é o fato de que o conhecimento das circunstâncias nunca se apresenta concentrado e completo, mas disperso em pequenas porções incompletas e até contraditórias de informação, distribuídas entre os indivíduos, que as processam de acordo com sua própria percepção ${ }^{99}$. Diante da dispersão da informação, e da assimilação diferenciada pelos agentes, Hayek critica o modelo neoclássico de equilíbrio, por não levar em conta essas diferenças nos planos individuais, mas considera o sistema de preços o meio mais eficiente de comunicação da informação sobre escassez, por transmitir todos os dados essenciais e suficientes para a tomada de decisões e dirigir-se somente àqueles a quem interessa. $^{100}$

Mas, como observa Stiglitz, não é só a escassez que interessa à economia, há muitos outros problemas de informação que interferem no equilíbrio econômico. Os empregadores querem prever a capacidade de seus trabalhadores; investidores fazem prognósticos a respeito do retorno de investimentos; seguradoras precisam conhecer o risco de acidentes e de doenças a que cada um dos proponentes está exposto. Além desses problemas de seleção, típicos da fase pré-contratual, há os de incentivo, característicos da fase posterior à celebração dos contratos, em que empregadores querem saber da dedicação e produtividade de seus empregados; seguradoras querem saber o cuidado que seus segurados tomam para evitar sinistros; mutuantes precisam conhecer a capacidade e disponibilidade de pagamento dos mutuários ${ }^{101}$. E esses problemas de informação se entrelaçam ao processo de trocas, afetando o sistema de preços e o equilíbrio do mercado.

\footnotetext{
${ }^{97}$ ARROW, Kenneth J. Information and economic behavior, cit., p. 137.

${ }^{98}$ KNIGHT, Frank Hyneman. op. cit., Part II. Chapter VIII. p. 238-239.

${ }^{99}$ HAYEK, F. A. Economics and knowledge. Economica, New Series, v. 4, n. 13, p. 33-54, Feb. 1937. p. 33-54.

${ }^{100}$ Hayek concentrou o foco no uso da informação, que interessa mais ao nosso tema do que a produção. HAYEK, F. A. The use of knowledge in society. The American Economic Review, v. 35, n. 4, p. 519-530, Sept. 1945.

${ }^{101}$ STIGLITZ, Joseph. op. cit., p. 1441-1478.
} 
O desenvolvimento dos mercados e a diversificação de produtos aumentaram a necessidade de prover outras informações aos compradores, além do preço, assim como a evolução do mercado de crédito passou a exigir mais conhecimento a respeito dos próprios agentes econômicos, sua disponibilidade e disposição para cumprir as obrigações contratadas. Embora não se tenha abandonado o sistema de preços como um comunicador eficiente de informações sobre o mercado, constata-se que nem sempre é suficiente.

A assimetria informacional, os problemas por ela causados e as soluções de mercado para elidi-los ou reduzi-los, foram analisados especialmente por George Akerlof, Michael Spence e George Stiglitz, cujos trabalhos mereceram o prêmio Nobel de Economia de 2001. Suas contribuições, sempre associadas à deficiência de informação ${ }^{102}$, focalizaram fenômenos aparentemente diferentes, mas com mecanismo análogo, representando, a nosso ver, mais um desenvolvimento do que uma ruptura em relação à escola neoclássica, ${ }^{103}$ e consolidando definitivamente a economia da informação no pensamento econômico ${ }^{104}$.

\section{O papel das instituições}

Neste contexto em que se reconhece a existência de custos de transação, representados pelos atritos provocados pela interação dos agentes, destaca-se a importância das instituições.

Instituição tem várias acepções, de acordo com o ramo do conhecimento a que concerne. No âmbito do Direito é entendida como conjunto de normas aplicáveis a determinado fato jurídico ${ }^{105}$. Genericamente remete a leis e também a normas estabelecidas por tradição, acepção mais ampla, que nos interessa especialmente neste trabalho. O termo adotado pela escola denominada Nova Economia Institucional ${ }^{106}$, corresponde às regras

\footnotetext{
${ }^{102}$ LOFGREN, Karl-Gustaf; PERSSON, Torsten; WEIBULL, Jorgen W. op. cit., p. 195-211.

${ }^{103}$ Stiglitz sustenta ter havido uma ruptura, mas os elementos fundamentais da teoria da informação não contrariam inteiramente o paradigma neoclássico. The contributions of the economics of information to twentieth century economics, cit., p. 1441-1478. Para uma análise da interação das constatações da racionalidade limitada, da teoria da informação e da economia comportamental com os primados da escola neoclássica, v. ARAÚJO, Fernando. op. cit., p. 306-307.

${ }^{104}$ Os estudos de Akerlof, Nelson, Spence e Stiglitz serão focalizados com a abordagem das soluções de mercado para a redução dos efeitos da assimetria informacional.

${ }^{105}$ PONTES DE MIRANDA, Francisco Cavalcanti. Tratado de direito privado. Rio de Janeiro: Borsoi, 1954. v. 1, p. 124.

${ }^{106}$ A Nova Economia Institucional é uma escola de pensamento econômico que não se apresenta como uma alternativa à tradição neoclássica, porque adota algumas de suas premissas, mas reconhece a importância das instituições, principalmente por considerar a existência de custos de transação e das limitações da
} 
formais ou informais que balizam o comportamento humano, aí compreendidos os sistemas de regras e as estruturas organizadas para a sua aplicação. ${ }^{107}$

Essas regras, que modelam e orientam a interação humana, podem ser informais, como os usos e costumes, os valores morais, culturais, ideológicos e religiosos, ou formais, como as normas positivadas. Articuladas numa sintaxe de mútua influência, essas regras compõem o ambiente institucional.

Sempre que há custos de transação, as instituições desempenham papel essencial ${ }^{108}$, como meio de incentivar a cooperação, induzir maior aderência dos agentes às suas obrigações, assegurando seu cumprimento, e, com isso, reduzir custos de transação, inclusive os relativos à informação ${ }^{109}$, e garantir maior estabilidade e segurança.

Qualquer sistema jurídico contratual tem o objetivo de facilitar as trocas, como constata Ian Macneil, no texto em que trata da constante tensão na conjuntura econômica moderna entre a necessidade de estabilidade e a urgência de resposta à mudança ${ }^{110}$. Ele observa que o tratamento jurídico tradicional dos contratos ${ }^{111}$ corresponde ao ideal de mercado da economia clássica, argumentando que, para ambos, os atributos das partes eram irrelevantes; os termos do contrato perfeitamente delimitados, com a finalidade de antecipar todas as possíveis contingências, e as sanções estritamente previstas para o caso

racionalidade e da assimetria informacional entre os agentes. Se a tomada de decisão é dificultada pela deficiência de informação e pelas limitações da racionalidade, e se a interação humana produz 'atritos' que oneram o processo econômico, é relevante o papel das instituições que conformam esses comportamentos. North afirma que sua teoria das instituições nasceu da combinação da teoria do comportamento humano com a teoria dos custos de transação. Daí ele extrai a explicação da existência das instituições e o papel que elas desempenham na sociedade. NORTH, Douglas. op. cit., p. 27.

${ }^{107}$ Assim, por exemplo, o mercado é instituição, por ser um conjunto sistematizado de regras atinentes à circulação de bens e serviços. E o Direito também é um sistema de regras formais que balizam a interação humana.

${ }^{108}$ No capítulo introdutório de The Firm, the Market and the Law, Coase destaca a importância das regras formais em relação aos custos de transação: "What I showed in "The Problem of the Social Cost" was that, in the absence of transaction costs, it does not matter what the law is, since people can always negotiate without costs to acquire, subdivide, and combine rights, whenever this would increase the value of production. In such a world the institutions which make up the economic system have neither substance nor purpose.” op. cit., p. 14. A intelecção a contrario sensu desta interpretação autêntica do teorema de Coase, permite concluir que as instituições informais (normas sociais, usos e costumes) e as formais (jurídicas, regulatórias em geral) exercem função relevante e até indispensável no mundo real, em que os custos de transação são sempre positivos.

${ }^{109}$ A literatura econômica reconhece os custos implicados na busca de informação. Além de Coase e Stigler, citados anteriormente, também Harold DEMSETZ, Harold. The theory of the firm revisited. Journal of Law, Economics and Organization, v. 4, n. 1, p. 141-161, 1988.

${ }^{110}$ MACNEIL, Ian R. Adjustment of long-term economic relations under classical, neoclassical and relational contract law. Northwestern University Law Review, n. 72, p. 870-871, 1978.

${ }^{111} \mathrm{O}$ autor se refere aqui ao que ele denomina direito contratual clássico, que corresponde ao século XIX até as primeiras décadas do século XX, tendo atingido o ápice com Samuel Willinston em 'Law of Contracts' (1920) e Restatement of Contracts (1932). O direito contratual neoclássico se refere ao sistema fundado na mesma estrutura jurídica, com consideráveis alterações, representadas pelo Restatement Second of Contracts. 
de descumprimento das obrigações originalmente pactuadas, sem qualquer abertura para renegociação ${ }^{112}$. Portanto, não é qualquer contrato que se encaixa nesse modelo clássico. A incerteza inerente aos contratos de longa duração torna a técnica tradicional de perfeita previsão do futuro muito onerosa, senão impossível. Esses contratos, incompletos por natureza, exigem mais flexibilidade, e, portanto, um regime jurídico menos rígido, que caracteriza a fase neoclássica do direito contratual, segundo Macneil ${ }^{113}$. O progressivo aumento da complexidade do contrato, cujas disposições se projetam para um futuro cada vez mais distante, impôs a necessidade de adaptação do direito contratual a essa nova realidade, descartando-se completamente a ficção da antecipação do futuro e dos contratos pretensamente completos, e assumindo-se a sua inegável incompletude. Instaura-se assim um processo de contratação, que se distingue do tratamento jurídico neoclássico porque não mais se toma o contrato original como ponto de referência, mas todo o 'processo relacional' que se desenvolve ao longo do tempo. Esta evolução do direito contratual na sua adaptação ao tratamento dos contratos relacionais, retratada por Macneil, pode ser constatada principalmente nas relações comerciais, societárias e trabalhistas.

Contratos serão espontaneamente cumpridos na medida em que os benefícios de cumpri-los excederem os custos. Em geral o cumprimento espontâneo está associado a contratos relacionais repetitivos, e nos casos em que as partes se conhecem bem e fazem parte de um grupo restrito, pois aí o benefício sempre compensará o custo, em razão da densa conexão das partes a uma estreita rede social, cujas regras informais são muito influentes. ${ }^{114}$ A repetição das relações jurídicas entre as mesmas partes, ao longo do tempo, acaba aplainando a disparidade de informação inicialmente existente, em função da própria reedição dos contratos, e tende a estreitar a conexão entre as partes, criando freios sociais e morais que reprimem o oportunismo e promovem maior comprometimento entre os contratantes. Essa é uma das funções das instituições consistentes nas regras informais, que podem exercer efeito tanto ou mais repressivo do que as regras formais, e contribuir para criar um ambiente mais propício à aplicação destas.

Mas a impessoalidade das relações negociais, a distância entre as partes, a assimetria de informação, características mais comuns da economia atual, propiciam o oportunismo e desfavorecem a cooperação, exigindo a instituição de um sistema bem articulado para ser apto a assegurar o cumprimento dos contratos. A cominação de sanções

\footnotetext{
${ }^{112}$ MACNEIL, Ian R. op. cit., p. 864.

${ }^{113}$ Id. Ibid., p. 865.

${ }^{114}$ Id. Ibid., p. 854-906.
} 
ao descumprimento de obrigações, a presunção legal do conhecimento da lei, a eficiente proteção dos direitos de propriedade ${ }^{115}$, a redução da incerteza e da imprevisibilidade, a imposição coercitiva do cumprimento dos contratos, são fatores que reduzem custos de transação ${ }^{116}$, e aumentam a confiança entre os agentes e a segurança jurídica.

A criação de um ambiente institucional que efetivamente induza cooperação e comprometimento envolve um complexo sistema de normas formais, regras informais, e garantias de cumprimento (enforcement), que juntos viabilizam a redução de custos de transação, ${ }^{117}$ favorecem as trocas e promovem o desenvolvimento. Por isso se afirma que as instituições determinam o desempenho da economia.

Uma das funções mais importantes das instituições é justamente reduzir a incerteza $^{118}$, auxiliando no tratamento dos riscos e da disparidade de informação, criando ambiente seguro e propício para as trocas. Estabelecer estrutura estável para a interação humana é o primeiro passo para a consecução desse objetivo. ${ }^{119}$ E a estabilidade das instituições contribui para a previsibilidade, o que é fundamental para melhorar o funcionamento do sistema econômico. Mas a estabilidade não se contrapõe ao processo de evolução a que as instituições estão sujeitas ao longo do tempo, devido à sua relação simbiótica com as organizações, desenvolvidas em consequência da estrutura de incentivos criada pelas instituições e pelo processo de realimentação pelo qual os seres humanos percebem e reagem às mudanças no ambiente institucional. É, pois, um processo de interação e influência recíproca. ${ }^{120}$ Sua eficiência depende da construção de uma política de incentivos para atribuição e garantia efetiva dos direitos de propriedade, o que, por sua

\footnotetext{
${ }^{115}$ Direitos de propriedade têm conotação diversa em Direito e em Economia. Decio Zilbersztajn e Rachel Sztajn explicam essa diferença da óptica de cada uma das áreas de conhecimento. A concepção jurídica do direito de propriedade corresponde a um feixe que engloba os direitos de uso, fruição e disposição e que concede o exercício da exclusão sobre a coisa, e o exercício de sequela, que permite retomá-la de terceiros que dela se apropriem indevidamente. Em Economia, parte-se do conceito de que o que se negocia não são os bens como objetos de Direito, mas, sim, direitos de propriedade sobre dimensões de bens, como abordado pioneiramente por Ronald Coase, no estudo da natureza da empresa e dos custos de transação (The Nature of the Firm e The Problem of Social Cost). Coase propõe que, na ausência de "custos de transação", a alocação ou distribuição inicial dos direitos de propriedade sobre as dimensões dos bens não terá importância, pois os agentes negociarão a transferência dos direitos a custo zero podendo realocá-los eficientemente. Assim, construiu-se boa parte da Análise Econômica do Direito sob a óptica da Nova Economia Institucional, que está voltada primordialmente para a lógica econômica dos arranjos contratuais relacionados à criação dos direitos. SZTAJN, Rachel; ZYLBERSZTAJN, Decio. Direito e economia. Rio de Janeiro: Elsevier, 2005. p. 85.

${ }^{116}$ NORTH, Douglas. C. op. cit., p. 55.

${ }^{117}$ Id. Ibid., p. 57-58.

${ }^{118}$ Id. Ibid., p. 25 . O alto custo da informação é a chave para os custos de transação que consiste nos custos de avaliar os atributos do objeto das trocas econômicas, de proteger direitos e assegurar o cumprimento dos acordos.

${ }^{119}$ Id. Ibid., p. 3-4.

${ }^{120}$ Id. Ibid., p. 6-7.
} 
vez, decorre das regras informais derivadas da transmissão cultural de valores. Isso explica os diferentes níveis de desenvolvimento entre países. ${ }^{121}$

A função institucional do Direito é incentivar a troca de informações e a cooperação entre as partes, assegurando a confiabilidade dos contratos e reduzindo os atritos do processo econômico geradores de custos, que podem ser evitados ou minimizados. E ao identificar situações em que a auto-regulação do mercado se revela inapta, promover a interação mais eficiente e justa entre os agentes, de forma que eventuais problemas sejam corrigidos, ou mitigadas suas consequências, ao menor custo. ${ }^{122}$

Este papel do Direito, como indutor de comportamentos e redutor de custos de transação, se tornou mais relevante com a crescente interação e o desenvolvimento dos mercados, que alargaram a esfera de atuação dos agentes, e acentuaram a complexidade das relações negociais.

As disparidades de informação em matéria contratual, eventualmente nocivas ao funcionamento da economia são frequentemente aplainadas por meio de soluções do próprio mercado, ou mediante soluções extramercado, ditadas pelo Direito, cuja aptidão para resolver os problemas criados pela assimetria informacional será discutida na abordagem das instituições jurídicas aplicáveis ${ }^{123}$.

\section{Efeitos da assimetria informacional}

A má distribuição de informação entre os agentes é uma característica comum das interações do mercado e, quando provoca efeitos indesejáveis, enseja reações defensivas dos próprios agentes. Analisando as conclusões dos mais notáveis estudos econômicos que focalizaram a assimetria informacional, Lofgren, Persson e Weibull relacionam fenômenos de diversos setores da economia, mostrando que o traço comum a todos eles é a disparidade de informação entre as partes numa dada relação jurídica. Assim, a elevação das taxas de juros e o racionamento de crédito são respostas do mercado à seleção adversa ou ao moral hazard, seja por uma das partes não poder distinguir a qualidade do produto

\footnotetext{
${ }^{121}$ NORTH, Douglas. C. op. cit., p. 138-140.

${ }^{122}$ Mesmo quando existir ineficiência e até falha de mercado e as circunstâncias indicarem a inaptidão de auto-correção, a regulação dependerá da ponderação entre os benefícios e os custos por ela gerados, as falhas da própria regulação estatal e a possibilidade de captura do regulador por interesses privados, fatores que devem ser considerados na decisão de regular ou não o mercado. STIGLER, George J. The theory of economic regulation. The Bell Journal of Economics and Management Science. v. 2, n. 1. p. 3-21, Spring, 1971.

${ }^{123} \mathrm{~A}$ disciplina jurídica da informação nos contratos será abordada no próximo capítulo.
} 
ou serviço ou os atributos da contraparte, seja por não poder acompanhar as ações da contraparte. Pelas mesmas razões, vendedores de veículos de boa qualidade oferecem garantias do produto para se manterem no mercado de carros usados, afastando os efeitos da seleção adversa, e candidatos a emprego comprovam a qualidade de sua formação mediante apresentação de diplomas, certificados de proficiência. No intuito de reduzir o moral hazard, no mercado de seguros, apólices contemplam fatores dedutíveis do total da cobertura, de modo a partilhar o risco com o segurado, e, no mercado agrícola, contratos de arrendamento atribuem o risco da colheita ao arrendatário, exatamente em razão de o arrendante não poder monitorar as ações da contraparte. ${ }^{124}$

Tipicamente, a parte mais informada se prevalece de sua condição, desde que lhe seja conveniente, e, se não for, tenta transmitir a informação à contraparte; e a parte menos informada busca meios de extrair informações da outra, sempre que perceber que a inferioridade informativa a prejudica ${ }^{125}$.

Analisando o mercado de seguros, Stiglitz e Rothschild apontam a importância da informação que permeia os contratos, aduzindo que algumas conclusões importantes da teoria econômica não se sustentariam se as análises considerassem as imperfeições de informação. Eles demonstram que, com assimetria informacional, o equilíbrio competitivo pode não existir, e quando existe, pode ter propriedades estranhas ${ }^{126}$.

Os efeitos se manifestam na fase de formação do contrato, ou no curso de sua execução e nem sempre se restringem aos contratantes, irradiando-se pelo mercado e causando desequilíbrio. O primeiro, conhecido como seleção adversa, é geralmente associado à ocultação da informação que só um dos contratantes detém (hidden knowledge), e o segundo, identificado como moral hazard, concerne à dificuldade de uma parte monitorar as ações da outra durante a execução do contrato (hidden action).

\footnotetext{
${ }^{124}$ LOFGREN, Karl-Gustaf; PERSSON, Torsten; WEIBULL, Jorgen W. Markets with asymmetric information: the contributions of George Akerlof, Michael Spence and Joseph Stiglitz. The Scandinavian Journal of Economics, v. 104, n. 2, p. 195-211, Jun. 2002. p. 195-211.

${ }^{125}$ Apesar da aparente trivialidade desse problema da disparidade informacional e seus efeitos, sua importância atraiu a atenção de muitos economistas, como Akerlof, Spence e Stiglitz, cujos trabalhos que desenvolveram estudos sobre mercados caracterizados por assimetria informacional, com ampla aplicação, desde tradicionais mercados agrícolas até os modernos mercados financeiros. Id. Ibid., p. 195-211.

${ }^{126}$ ROTHSCHILD, Michael; STIGLITZ, Joseph. op. cit., p. 629-649.
} 


\section{Seleção Adversa}

Seleção adversa é o efeito que se manifesta anteriormente à contratação, e decorre da disparidade de informação em relação às qualidades do produto ou serviço ou dos atributos da contraparte. Embora possa afetar vários setores da economia, o paradigma sempre lembrado é o mercado de carros usados, utilizado por George Akerlof no artigo seminal $^{127}$, sempre citado na literatura econômica.

Nesse trabalho, Akerlof explica como a incerteza em relação à qualidade dos produtos e aos atributos dos contratantes pode induzir ao mau funcionamento da economia, apontando a seleção adversa como sua principal consequência. Retrata o mercado americano de carros usados, em que a qualidade dos produtos é heterogênea e a informação assimétrica, e estende suas observações a outros segmentos, direcionando o foco de seu estudo principalmente aos seguros privados e apontando os efeitos gerados pela incerteza nesses mercados.

Esse problema afeta bens ou serviços cujas qualidades não se possam constatar ictu occuli. No texto em que avalia o estágio das pesquisas no âmbito da informação, Hirshleifer pondera que a incerteza concernente à qualidade acarreta um problema intrinsecamente mais complexo do que a incerteza relativa a preços, porque a qualidade é multidimensional, difícil de ser quantificada e qualificada, e depende da autenticidade das declarações dos vendedores. ${ }^{128}$

Quanto à aferição da qualidade, Nelson já distinguia três categorias: os bens chamados de procura (search goods), que comportam aferição da qualidade mediante mera inspeção feita antes da celebração do contrato; bens denominados de experiência (experience goods), cujas qualidades só se revelam com o uso, e, portanto, após a celebração do contrato; e bens de confiança (credence goods), cujas qualidades demoram a ser constatadas mesmo com o uso ${ }^{129}$.

\footnotetext{
${ }^{127}$ AKERLOF, George. op. cit., p. 488-500.

${ }^{128}$ Neste texto, o autor se propõe a traçar um panorama da teoria da informação, e, por isso, não focalizou detidamente a assimetria informacional, razão pela qual se refere aqui apenas à incerteza dos compradores, quanto à qualidade, embora os vendedores também sejam afetados por esse fenômeno, como ocorre, por exemplo, nos mercados de crédito e de seguros. HIRSHLEIFER, Jack. Where are we in the theory of information?, cit., p. 37.

${ }^{129}$ NELSON, Philip. Information and consumer behavior. Journal of Political Economy, n. 78, p. 311-329, 1970.
} 
No caso do carro usado, a qualidade do bem só se constata efetivamente com o uso. $\mathrm{O}$ vendedor tem muito mais conhecimento do carro colocado à venda, do que o comprador. Neste contexto, o vendedor de um carro usado de má qualidade (lemon), é induzido a vendê-lo como se fosse um bom carro (cherry), já que, nesse mercado, o comprador dificilmente teria meios de distinguir um produto bom de um ruim, por se tratar de bens de experiência, cuja qualidade só se conhece com a efetiva utilização. Isso cria uma externalidade negativa ${ }^{130}$ em relação aos vendedores de carros bons, porque afeta a percepção dos compradores sobre a qualidade do carro médio no mercado, e acaba reduzindo o preço que estes estariam propensos a pagar pelo carro médio, prejudicando os vendedores de carros bons. ${ }^{131} \mathrm{O}$ desconhecimento do comprador a respeito do produto funciona como um incentivo a que ele não se disponha a pagar um preço compatível com um produto de boa qualidade, porque ele sabe de antemão que nem todos os produtos ofertados são bons, e que não conseguirá distinguir a qualidade dentre eles. A reiteração desse comportamento de compradores e vendedores, estes ocultando a qualidade do bem e aqueles não se propondo a pagar o preço do bem de boa qualidade, se refletirá negativamente sobre o mercado. Em decorrência disso, o preço dos produtos bons e ruins será nivelado pela média, o que poderá implicar, afinal, a exclusão dos bons, cujos proprietários tenderão a não vendê-los, ou a vendê-los exclusivamente a conhecidos, que, cientes da qualidade do produto, estarão dispostos a pagar por ele preço compatível com sua efetiva qualidade. Portanto, o mercado de carros usados pode acabar restrito aos carros ruins destinados aos compradores que não se arriscam a pagar mais por um carro bom, ou que não têm recursos para tanto. Segundo Akerlof, este é o custo da desonestidade, que afeta mais os países subdesenvolvidos, e não está apenas no valor que engana o cliente, mas na perda decorrente da extinção dos negócios legítimos, que reduz o tamanho do mercado $^{132}$. A desonestidade a que Akerlof se refere corresponde à deslealdade e à má-fé, tantas vezes premiadas pela fragilidade das normas sociais, que tendem a relevar o oportunismo, ou até a valorizar a astúcia a este subjacente, e, por isso mesmo, não o reprovam, e pela precariedade do sistema jurídico, seja na elaboração ou na aplicação das leis. A forma como os contratantes encaram o vínculo assumido e o cumprimento de suas obrigações é estreitamente conexa com o ambiente institucional, que pode incentivar, ou

\footnotetext{
${ }^{130}$ Externalidade (spill over effect) se refere a um impacto econômico sobre terceiro estranho à relação originária. IPPOLITO, Richard A. Economics for lawyers. New York: Princeton University Press, 2005. p. 229. Será positiva se beneficiar o terceiro, e negativa, se prejudicá-lo, impondo-lhe custos.

${ }^{131}$ VARIAN, Hal R. op. cit., p.747.

${ }^{132}$ AKERLOF, George. op. cit., p. 495.
} 
não, a confiança recíproca. Esta é razão pela qual o mesmo instituto não surte efeitos iguais em contextos sócio-culturais diferentes ${ }^{133}$.

A assimetria da informação não afeta apenas os compradores, mas também os vendedores. A impossibilidade de distinguir produtos e serviços, que acarreta a seleção adversa, implica também a dificuldade de avaliar os riscos potenciais da contraparte, e, pelas mesmas razões, provoca distorção no mercado. Já se observou que, quando o comprador não consegue distinguir a qualidade dos produtos ofertados, tende a nivelar o preço para baixo, o que atrairá produtos cada vez piores, numa espiral decrescente, redundando na expulsão dos bons. Analogamente, se o vendedor não consegue avaliar $a$ priori os riscos eventualmente representados pela contraparte, tenderá a incluir essa incerteza no preço, e o aumento de preço atrairá compradores de maior risco ainda, numa espiral crescente.

Esse fenômeno ocorre em todos os setores em que os compradores não conseguem distinguir a qualidade dos produtos ou serviços, e o preço é nivelado pela média ${ }^{134}$. O mercado de trabalho, o financeiro e o de seguros privados são exemplos paradigmáticos de seleção adversa.

Apontando a seleção adversa subjacente às contratações no âmbito das relações trabalhistas, Spence ${ }^{135}$ afirma que o empregador sempre investe sob incerteza, pois não conhece as habilidades dos candidatos ao emprego, e só poderá conhecê-las algum tempo depois da admissão. Tanto que Mackaay, observando as categorias de Nelson, classifica esses profissionais como bens de confiança ${ }^{136}$. Stigler também aludiu à dificuldade de avaliação de candidatos a emprego, especialmente os pertencentes a classes menos

\footnotetext{
${ }^{133}$ Esta questão será retomada com o estudo da boa-fé, instituto que carrega consigo a tradição cultural do ambiente institucional ao qual se aplica, e, por isso mesmo, nem sempre funciona bem, e, pior, frequentemente, surte o efeito contrário ao que se propõe, porque sua natureza ambígua se presta a interpretações antagônicas.

${ }^{134}$ Schäfer e Ott dão o exemplo dos restaurantes de pontos turísticos, que são geralmente visitados uma única vez pelos turistas. Se um dos restauranteurs, considerando a circunstância de que sua clientela é exclusivamente de turistas, reduzir a qualidade da comida, mesmo mantendo o preço, não sofrerá nenhuma sanção do mercado, porque turistas de uma única vez não conseguiriam distinguir a má qualidade daquele produto dos outros de boa qualidade. Os demais restauranteurs tenderiam a seguir esse movimento, chamado espiral descendente, o que acarretaria a exclusão dos bons produtos e serviços daquele mercado. SCHÄFER, Hans-Bernd; OTT, Claus. op. cit., p. 231.

${ }^{135}$ SPENCE, Michael. Job market signaling. Quarterly Journal of Economics, n. 87, n. 3, p. 356 e 358, Aug. 1973.

${ }^{136}$ MACKAAY, Ejan; ROUSSEAU, Stéphane. op. cit., p. 366-368. Por isso, a escolha de empregados ou prestadores de serviços cujos dotes em geral se desconhecem ou, quando muito, se presumem, equivale a um investimento de risco, mormente se considerada a severidade das leis trabalhistas.
} 
favorecidas ou minorias étnicas. ${ }^{137}$ Akerlof mostra que a interação entre diferenças de qualidade e incerteza explicam importantes instituições nos mercados, como garantias oferecidas por vendedores, certificados de origem de produtos, marcas e sinais identificadores, certificações indicativas de graus de proficiência, como diplomas e licenças, que também funcionam como 'marcas', certificando a qualidade dos candidatos a emprego $^{138}$.

No mercado financeiro a assimetria de informação também provoca seleção adversa, afetando a eficiência alocativa de recursos. Crédito, como o nome indica, pressupõe confiança. A oferta de crédito é feita na medida da confiança em relação à sua recuperação. E a credibilidade advém de informação a respeito da aptidão do tomador de restituir o valor objeto do mútuo. Quanto melhor a qualidade dessa informação, menor o preço do dinheiro emprestado. Mas, como a instituição financeira não tem informações que lhe permitam identificar os tomadores de recursos com menor risco de inadimplência, opta por fixar uma taxa de juros capaz de compensar a possibilidade de inadimplemento nos casos de maior risco. A consequência de balizar a taxa média de juros, tomando como parâmetro a possibilidade do maior risco, provoca seleção adversa, porque isso atrai os empreendedores de projetos mais arriscados e com maior probabilidade de inadimplir a obrigação (lemons), e afugenta os mais cautelosos e tendentes a restituir o valor emprestado. A taxa de juros que um potencial tomador de recursos se dispõe a pagar pode funcionar como screening device, ou seja, como meio de testar sua capacidade ou disposição de restituição do empréstimo. Os que estão dispostos a pagar taxas mais altas geralmente são os que representam maior risco de inadimplemento ${ }^{139}$. Portanto, o aumento do preço do dinheiro corresponderá a uma redução da probabilidade de restituição do empréstimo. A solução do problema não é simples. Primeiro, porque a obtenção de informações nesse mercado, quando é possível, aumenta muito os custos de transação, a ponto de eventualmente inviabilizar a contratação. Segundo, porque fixar a remuneração do capital em um patamar mais baixo, levando em conta os tomadores de menor risco,

\footnotetext{
${ }^{137}$ STIGLER, George. J. Information in the labor market. Journal of Political Economy, v. 70, n. 5, p. 104, Oct. 1962. Part 2: Investing in Human Beings.

${ }^{138}$ AKERLOF, George. op. cit., p. 494-495 e 500.

${ }^{139} \mathrm{O}$ mecanismo das relações de crédito sempre esteve no foco da literatura econômica. Para demonstrar as causas do racionamento de crédito, Jaffe e Russel conceberam um modelo simples, com dois tipos de devedores: os honestos, que só aceitam baixas taxas de juros porque se dispõem efetivamente a quitar seus empréstimos; e os desonestos, que não se importam com o custo do empréstimo, porque sabem que optarão por não quitar o débito, se isso lhes proporcionar aumento de utilidade. JAFEE, Dwight; RUSSEL, Thomas. Imperfect information, uncertainty and credit rationing. Quarterly Journal of Economics, v. 90, n. 4, p. 651-666, nov. 1976.
} 
acarretará aumento da demanda, que pressionará novamente o preço do dinheiro, elevando a taxa de juros. Stiglitz e Weiss ${ }^{140}$ mostram que, num mercado caracterizado por assimetria informacional, é melhor que os bancos racionem o volume de crédito em vez de aumentarem a taxa de juros para reduzir perdas decorrentes de maus empréstimos. Mesmo que a demanda fosse maior do que a oferta, os bancos não deveriam elevar muito as taxas de juros, porque isso aumentaria demais o seu risco e reduziria a possibilidade de lucro. Assim, a seleção adversa induz à retração do crédito, excluindo do mercado grande parcela de investidores com projetos economicamente viáveis e incentivando o desenvolvimento de um setor paralelo, informal, o que provoca a fragmentação do sistema e prejudica o desenvolvimento econômico.

Esse fenômeno, subjacente a todo o mercado de crédito, afeta até mais severamente o mercado de seguros privados, também parte do sistema financeiro, que, em razão do caráter intertemporal das obrigações envolvidas, se torna mais vulnerável aos efeitos da assimetria informacional. A expressão seleção adversa foi utilizada pela primeira vez em relação a este segmento, para descrever a dificuldade de as seguradoras obterem uma seleção randômica e imparcial de segurados ao se basearem na probabilidade média de sinistros para fixar o preço do seguro. Constatou-se que a seguradora tende a obter uma seleção adversa de segurados, que, em dadas circunstâncias, só se disporão a pagar o preço calculado pela média, entre o risco mais elevado e o mais baixo. Com isso, serão atraídos os potenciais segurados com uma alta incidência de risco. Elevado o preço, o seguro não compensará para os proponentes de baixo risco. Akerlof aponta a dificuldade de pessoas de mais de sessenta e cinco anos contratarem seguro-saúde, pois o nível de preço aumenta conforme a condição médica média dos proponentes deteriora, e o preço muito alto atrairá somente os que se sabem menos saudáveis. ${ }^{141}$ Embora o problema do seguro-saúde seja análogo ao dos carros usados, a solução em matéria de seguro é muito mais complexa.

A atração de riscos mais elevados desencadeada pela assimetria informacional não permite ao segurador identificar e mensurar corretamente os riscos assumidos porque, na fase pré-contratual, os proponentes, cientes da disparidade de informação a seu favor, tendem a ocultar os dados que evidenciariam a real dimensão do risco a que estão sujeitos os interesses que pretendem segurar. Os potenciais segurados assim agem, por saberem que as informações desfavoráveis omitidas ou distorcidas, se reveladas, encareceriam sua

\footnotetext{
${ }^{140}$ STIGLITZ, Joseph E.; WEISS, Andrew. Credit rationing in markets with imperfect information. The American Economic Review, v. 71, n. 3, p. 393-410, Jun., 1981.

${ }^{141}$ AKERLOF, G. op. cit., p. 492-493.
} 
prestação. Mesmo desconhecendo o mecanismo dos cálculos atuariais, os proponentes têm noção de que quanto mais alto o risco, mais caro o prêmio, até porque isso é intuitivo. Por outro lado, sabem que a seguradora dificilmente poderia obter por si própria essas informações, e mesmo se pudesse buscá-las, isso aumentaria demais os custos de transação, a ponto de eventualmente inviabilizar a operação de seguros. E, se o segurador computar no preço a incerteza quanto aos riscos, elevará a média do valor dos prêmios, atraindo riscos bons e afastando ruins, o que desequilibra o mercado.

Essa disparidade de informação poderia ser reduzida a um custo muito baixo, em benefício de toda a sociedade, impondo-se ao potencial segurado o dever de informação, independentemente do elemento subjetivo, tanto na fase pré-contratual como na execução do contrato ${ }^{142}$.

\section{Moral Hazard. ${ }^{143}$}

A assimetria de informação também provoca efeitos posteriores à celebração do contrato de execução diferida ou continuada, pois a dificuldade ou impossibilidade de uma parte de acompanhar as ações da outra no curso da execução da avença, incentivará o comportamento negligente ou oportunista desta em detrimento do direito da outra.

Moral hazard corresponde ao descuido, negligência ou oportunismo de uma parte em relação ao cumprimento de suas obrigações, incentivada pela certeza de que a contraparte não pode monitorar sua conduta no curso da execução do contrato. Existe nas relações de seguro um conflito de interesses latente ${ }^{144}$, que se manifesta em duas oportunidades. A primeira, já comentada, decorre de a fixação do preço da cobertura depender das informações do segurado, que tende a mascarar o risco, para reduzir o

\footnotetext{
${ }^{142}$ No tópico atinente à declaração de risco analisaremos o direito aplicável à espécie.

${ }^{143}$ A expressão moral hazard não será traduzida no texto, porque a tradução (perigo moral) não exprime seu real significado, não cumprindo sua função semântica.

${ }^{144}$ Spence and Zeckhauser observam que, se o mecanismo do seguro depende das informações fornecidas pelo próprio segurado, e está adstrito aos cálculos atuariais, que devem garantir a expectativa de equilíbrio financeiro do fundo comum, o objetivo do segurador é manter este equilíbrio. O segurado, por outro lado, tem incentivos para tentar extrair mais ganhos (indevidos) do contrato, por ter ciência da assimetria informacional que o favorece, pois se reduzir o zelo em relação ao interesse segurado, o segurador geralmente terá acesso a tal informação só após eventual sinistro, dada sua dificuldade de monitorar as ações dos segurados. SPENCE, Michael; ZECKHAUSER, Richard. Insurance, information, and individual action. The American Economic Review, v. 61, n. 2, p. 380, May, 1971. Papers and Proceedings of the Eighty- Third Annual Meeting of the American Economic Association.
} 
prêmio. A segunda se manifesta na tendência do segurado de reduzir investimento em cuidado, depois de garantido pela cobertura contra as perdas decorrentes do risco ${ }^{145}$.

Para caracterizar o moral hazard, os autores não distinguem a conduta negligente do comportamento típico dos conflitos de agência, em que o agent (representante, mandatário, administrador) atua intencionalmente em proveito de si próprio, e em detrimento dos interesses (do principal). A negligência consciente é equiparada ao oportunismo, pois ambos lesam a parte contrária, subtraindo indevidamente ganhos do contrato e desequilibrando a relação. A rubrica moral hazard se resume, pois, em oportunismo $^{146}$, como define Mackaay, e abrange esses dois tipos de conduta, uma culposa e outra dolosa, qualquer que seja o contexto em que se insiram ${ }^{147}$. A importância da abrangência da rubrica é mostrar a inadequação do enquadramento legal dessas condutas, que será discutido nos tópicos relacionados às declarações distorcidas ou às omissões do proponente e ao agravamento do risco pelo segurado no contrato de seguro.

A lei cogita do moral hazard ao tratar do agravamento do risco, que afeta a relação risco-prêmio, embora não sirva para coibir o oportunismo dos segurados.

Importa aqui caracterizar o oportunismo, que corresponde à busca de extrair do contrato vantagem indevida. No âmbito dos seguros privados, o oportunismo se configura tanto pela omissão ou distorção de informações conhecidas do segurado e relevantes em relação ao contrato, como pelo agravamento do risco, independentemente da intenção deste ${ }^{148}$.

\footnotetext{
${ }^{145}$ No mercado de seguro, a dificuldade de estabelecer o preço da garantia deriva da sua dependência das informações da contraparte. E, uma vez fixado preço, o segurador não sabe, de verdade, a extensão da garantia, porque depende em parte das ações do segurado, em relação às quais também não tem informação. Rothschild e Stiglitz ponderam que, se as pessoas estivessem dispostas ou aptas a revelar suas informações, todos poderiam ser beneficiados. Pessoas de alto risco causam uma externalidade: os indivíduos de baixo risco ficam em pior situação do que ficariam sem os indivíduos de alto risco. Mas indivíduos de alto risco não ficam em melhor situação do que ficariam sem os indivíduos de baixo risco. Rothschild e Stiglitz concluem que o equilíbrio de preço da análise de competição concorrencial é inviável; o equilíbrio de mercado, quando existe, consiste em contratos que especificaram tanto o preço quanto as quantidades; os indivíduos de alto risco provocam uma externalidade dissipativa nos indivíduos de baixo risco. ROTHSCHILD, Michael; STIGLITZ, Joseph. op. cit., p. 629-649.

${ }^{146} \mathrm{Hirshleifer}$ classifica também como moral hazard a ação dos vendedores de deliberadamente degradarem a qualidade do produto em resposta à ignorância do comprador, como no exemplo dos restaurantes turísticos referidos na literatura de assimetria informacional. HIRSHLEIFER, Jack. Where are we in the theory of information?, cit., p. 37-38.

${ }^{147}$ MACKAAY, Ejan; ROUSSEAU, Stéphane. op. cit., p. 126.

${ }^{148}$ Esta questão é apenas antecipada aqui para demonstrar a relação entre as constatações da análise econômica e as instituições jurídicas no âmbito do contrato de seguro, em que manifestações de oportunismo escapam frequentemente à sanção do Direito, em razão da redação deficiente da lei, ou de sua interpretação equivocada. $\mathrm{O}$ tema será discutido, adiante, nos tópicos pertinentes.
} 
Oportunismo é técnica conhecida de levar vantagem. Para caracterizá-lo não é preciso que a parte tenha a intenção de prejudicar à outra, como exige certa doutrina para a caracterização da má-fé. Basta que seja voluntária e espontânea, e que se possa, por indução e indícios, verificar o interesse de levar vantagem. Isso é suficiente para caracterizar má-fé, que, embora não possa ser presumida, nada impede seja demonstrada por prova indiciária, porque indício também constitui prova, e servirá, quando menos para inverter o ônus da prova contra aquele cuja conduta sugere ou indica oportunismo.

Estes efeitos ocorrem em vários segmentos do mercado ${ }^{149}$, mas são recorrentes nas relações de seguros privados, pois o segurado, ciente da impossibilidade de a seguradora observar suas ações relativas ao cumprimento do contrato, tende a tomar menos cuidado em relação aos riscos garantidos, aumentando a possibilidade de sua incidência. Como observa Shavell, moral hazard é uma tendência resultante da cobertura securitária de alterar a disposição do indivíduo de evitar perdas ${ }^{150}$. O comportamento corriqueiro derivado da prática de não zelar pelo que é de outrem, associado à certeza de que a garantia da cobertura afasta a possibilidade de perda patrimonial e dilui o risco, que o segurado não percebe mais como seu, faz com que ele tome menos cuidado para evitá-lo. São muitas as circunstâncias em que se identifica tal comportamento, por culpa ou por dolo. A falta de manutenção de sistema de alarme, ou de iluminação de segurança na propriedade protegida contra roubo, ou dos equipamentos contra incêndio, no bem coberto contra fogo, ou o uso cotidiano do veículo segurado para finalidade diversa da declarada, e dirigi-lo embriagado, são algumas das afrontas rotineiras à boa-fé e ao dever de informar nos contratos de seguro $^{151}$. Este simples rol serve para demonstrar também a relação entre seguro e responsabilidade civil, pois as condutas apontadas não lesam apenas o segurador, mas geram externalidades negativas, prejudicando terceiros ${ }^{152}$, e reduzindo o bem-estar de toda

\footnotetext{
${ }^{149}$ Nos contratos de crédito, como a instituição financeira não tem acesso a informações sobre a fiel execução do projeto que deu causa ao contrato de empréstimo, pois nem sempre pode monitorar o cumprimento das cláusulas inseridas no contrato para assegurar a consecução do projeto, o tomador tenderá a desconsiderar as recomendações, o que poderá comprometer sua capacidade de restituir o empréstimo. Essa é uma manifestação recorrente de moral hazard no mercado financeiro. Além disso, há as conhecidas externalidades negativas que incentivam o descumprimento das obrigações, que são os previsíveis óbices da execução forçada do contrato, representados pela demora no trâmite dos processos, e pela incerteza relacionada à interpretação e complementação dos contratos exequendos na esfera judicial, e a consequente imprevisibilidade das decisões. Tudo isso contribui para criar um ambiente institucional que não prestigia a confiança.

${ }^{150}$ SHAVELL, Steven. On moral hazard and insurance. The Quarterly Journal of Economics, v. 93, n. 4, p. 541-562, Nov. 1979.

${ }^{151}$ A estreita relação entre informação e boa-fé será destacada no próximo capítulo, na abordagem da disciplina jurídica da informação nos contratos.

${ }^{152}$ Esse tema será abordado oportunamente com o estudo do contrato de seguro.
} 
a sociedade. Esta é mais uma razão a recomendar rigor na apreciação judicial dos casos de responsabilidade civil e de agravamento do risco em matéria de seguro.

O monitoramento da contraparte durante a execução do contrato é materialmente impossível ou financeiramente inviável. Por isso, a cobertura parcial do risco é uma solução mais realista para problemas de moral hazard ${ }^{153}$. Nesse contexto, o grau recomendável de redução da cobertura e sujeição do segurado à eventual perda decorrente da materialização do risco dependeria dos incentivos a serem criados para a prática da prudência e do zelo, e estes, por sua vez, dependeriam do custo do comportamento prudente e zeloso ${ }^{154}$. A lógica subjacente a esta estratégia é que o cuidado e a lealdade contratual do segurado são diretamente proporcionais ao aumento da cobertura do risco, mas, como dificilmente podem ser observados ex ante, só surtirão efeito na reiteração dos contratos de seguro, pois, a repetição das relações jurídicas entre as mesmas partes aplaina disparidades de informação e reduz custos de transação.

Moral hazard aumenta os custos do segurador, que os imputa no prêmio, computando a incerteza que o acompanha, gerando menos bem-estar social, pois não só o risco é socializado por meio do seguro, mas o prejuízo causado por segurados oportunistas também. É o custo da desonestidade referido por Akerlof. É fácil ver que não se trata aqui apenas de eficiência, que é preocupação típica da Economia ${ }^{155}$, mas de justiça, foco precípuo do Direito. O oportunismo do segurado, nesses casos, aumenta custos de transação, revela falta de cooperação, contrariando os objetivos do sistema jurídico contratual.

Os efeitos nocivos dessa dinâmica perversa podem ser reduzidos e eventualmente eliminados por meio de soluções de mercado, ou quando inviável a auto-regulação, por soluções impostas por lei. Portanto, adotando um ou outro desses recursos, o ambiente institucional determinará maior ou menor eficiência do mercado.

\footnotetext{
${ }^{153}$ Spence e Zeckhauser concluem que se o segurador puder monitorar diretamente as ações dos segurados antes do sinistro, poderá evitar os incentivos adversos. Mas geralmente o segurador, embora ciente desses incentivos não consegue superar limitada capacidade de informação e monitoramento, nunca alcançará o nível ótimo, mas só a 'second best solution'. SPENCE, Michael; ZECKHAUSER, Richard. op. cit., p. 380387.

${ }^{154}$ SHAVELL, Steven. op. cit., p. 541-562.

${ }^{155}$ Muito embora devesse ser também do Direito.
} 


\section{Soluções de mercado para redução dos efeitos da assimetria informacional}

Antevendo efeitos eventualmente prejudiciais da disparidade de informações, os agentes concebem estratégias para evitar ou mitigar as distorções daí decorrentes. Estas instituições compensadoras da imperfeição informacional se aplicam geralmente às relações contratuais de execução diferida ou continuada.

É fundamental o papel das instituições nesse processo de disseminação de informações dos agentes mais informados para os menos informados, e de extração de informações dos agentes mais bem informados. Essa função de viabilizar a transmissão de informações no âmbito contratual, reduzindo custos de transação, também incumbe ao Direito, com a imposição do dever de informar e de cooperar, que são feições essenciais do instituto da boa-fé.

\section{Signaling: A sinalização promovida pela parte mais informada}

Uma das soluções instituídas pelo mercado é a sinalização dos produtos ou serviços com a finalidade de aplainar ou compensar a assimetria informacional: fornecedores de produtos ou serviços de boa qualidade têm interesse em que os compradores possam identificá-la, distinguindo-os dos demais.

Michael Spence ${ }^{156}$ demonstrou que agentes econômicos bem informados tenderão a sinalizar a boa qualidade de seus produtos ou serviços de forma tão crível quanto possível para obter melhor retorno do mercado.

Das instituições que têm o objetivo de neutralizar os efeitos da incerteza com relação à qualidade do produto ou serviço, a garantia é uma das mais recorrentes, e tende a convencer sobre a qualidade do produto, ao inverter o ônus do risco, que passa do comprador para o vendedor. ${ }^{157}$ Marcas de boa reputação, denominações de origem, classificação ou recomendação de especialistas, também são instituições que neutralizam

\footnotetext{
156“Sinalização" é um conceito introduzido por Spence, e funciona como um tipo de garantia implícita, porque coloca à prova a reputação do vendedor, que eventualmente também assume o risco da qualidade do produto. SPENCE, Michael. Job market signaling, cit., p. 355-374. SPENCE, Michael. Signaling in retrospect and the informational structure of markets. American Economic Review, n. 92, p. 434-459, 2002. (Este texto, que faz um retrospecto de sua teoria, foi baseado na palestra do autor na data em que recebeu o Nobel de Economia). Vide também LÖFGREN, K.G., PERSSON, T. e WEIBULL, J., que analisaram as contribuições de Akerlof, Spence e Stiglitz ao estudo das imperfeições de mercado, no artigo Markets with Asymmetric information: the contributions of George Akerlof, Michael Spence and Joseph Stiglitz. The Scandinavian Journal of Economics, v. 104, n. 2, p. 192-211, Jun. 2002.

${ }^{157}$ As marcas não apenas indicam qualidade, mas também permitem ao consumidor um meio de retaliação, se a qualidade não for a esperada, pois o consumidor reduzirá as compras futuras. Frequentemente também novos produtos são associados às marcas antigas. Isso garante ao consumidor prospectivo a qualidade do produto. Todas estas instituições são também referidas em AKERLOF, George. op. cit., p. 499-500.
} 
os efeitos da incerteza, distinguindo a qualidade que não se revela à simples inspeção do produto. Licenças, certificados de proficiência também reduzem a incerteza relacionada aos atributos do objeto da contratação ${ }^{158}$.

A publicidade, apesar de frequentemente destinada a instigar desejos antes nem cogitados pelos consumidores de modo a criar demanda, também transmite sinal $^{159}$ do fornecedor para o mercado, quando tem caráter informativo, distinguindo o produto, e revelando-lhe as qualidades, com argumentos fáticos constatáveis ${ }^{160}$. A propaganda é um processo de transferência de informação ${ }^{161}$, identificando os vendedores e sinalizando ${ }^{162}$ qualidade e preço de produtos ${ }^{163}$.

Mas a sinalização tem custos e os agentes tenderão a investir recursos até o limite do benefício esperado de tal investimento ${ }^{164}$, sob pena de incidirem em desperdício, gerando ineficiência. Por isso, o custo da sinalização deve ser recuperável, sob pena de torná-la inviável.

\footnotetext{
${ }^{158}$ Spence aponta um equilíbrio na sinalização: com a chegada de novos candidatos a emprego ao mercado, os ciclos se repetem. A percepção e a informação obtida pelos empregadores se altera, reajustando os salários oferecidos, o comportamento do candidato em relação aos sinais também se modifica, e após a admissão, novos dados estarão disponíveis ao empregador. Cada ciclo, assim, alimenta o seguinte, e pode ser interrompido em qualquer ponto. Um equilíbrio é um conjunto de elementos de um ciclo que se autoalimenta. SPENCE, Michael. Job market signaling, cit., p. 355-374.

${ }^{159}$ Sinais só são válidos na medida da informação que transmitem. Sinal que não informa, não cumpre sua função. HOLMSTROM, Bengt. Moral hazard and observability. The Bell Journal of Economics, v. 10, n. 1, p. 74-91, Spring, 1979.

${ }^{160}$ Comentando o trabalho revolucionário de George Stigler, que tratou da natureza e extensão da pesquisa e do comportamento da propaganda, Hirshleifer pondera que pesquisa e propaganda são processos informacionais complementares. O pesquisador localiza ofertas específicas, e o publicitário propaga informações sobre o produto, o que o autor denomina pulling e pushing na sua classificação de atividades dirigidas à informação. HIRSHLEIFER, Jack. Where are we in the theory of information?, cit., p. 35. Stigler também tratou da propaganda como instituição compensadora da assimetria informacional. STIGLER, George J. The economics of information, cit., p. 213-225.

${ }^{161}$ HIRSHLEIFER, Jack. Where are we in the theory of information?, cit., p. 38.

${ }^{162}$ Spence focalizou as instituições compensadoras que tendem a surgir para identificar produtos e serviços, que resumiu como sinalização, que traduz uma garantia implícita e remete à marca ou sinal a responsabilidade pela informação. SPENCE, Michael. Job market signaling, cit., p. 355-374. SPENCE, Michael. Signaling in retrospect and the informational structure of markets, cit., p. 434-459. Estes processos de transmissão de informação serão analisados com as soluções de mercado para combater os efeitos da assimetria informacional.

${ }^{163} \mathrm{Nelson}$ apontou a possibilidade dos consumidores monitorarem o conteúdo informativo da propaganda, principalmente em relação aos bens de inspeção. Mostrou que as principais características comportamentais da propaganda podem ser explicadas com base na função informativa da publicidade, como um sinal da qualidade do produto ou serviço, no mesmo sentido usado por Spence. NELSON, Phillip. Advertising as information. Journal of Political Economy, v. 82, n. 4, p. 729-754, Jul./Aug. 1974. A classificação de bens, proposta por Nelson, de acordo com a aptidão de serem conhecidos previamente ou posteriormente à compra, será analisada no tópico referente aos meios concebidos pelo mercado para combater ou minimizar os efeitos da assimetria informacional. NELSON, Philip. Information and consumer behavior, cit., p. 311-329.

${ }^{164}$ MACKAAY, Ejan; ROUSSEAU, Stéphane. op. cit., p. 128.
} 
Como o moral hazard afeta a relação risco-prêmio e o monitoramento do segurado apresenta extrema dificuldade operacional ${ }^{165}$, ao segurador resta dividir o custo do moral hazard, fazendo com que os segurados assumam parte das perdas, como forma de lhes incutir algum grau de responsabilidade pelo agravamento do risco ${ }^{166}$. Por isso, os seguros geralmente contemplam uma franquia, pela qual responde o próprio segurado, e, nesta medida, sua eventual imprudência ou negligência também se voltará contra ele próprio. A franquia geralmente é fixada até um limite, a partir do qual responde o segurador. Essa delimitação objetiva da cobertura é um recurso do próprio mercado para incentivar o zelo e a prudência do segurado, na tentativa de alinhar seus interesses com os da contraparte. A variação do montante da franquia, segundo Mackaay e Rousseau, permite modelar o sistema e identificar melhor o risco, operando como um recurso a favor do segurador, porque a aceitação de uma franquia alta sinaliza a prudência do segurado ${ }^{167}$. O seguro com descoberto obrigatório é outra instituição neutralizadora do moral hazard. Consiste na cobertura apenas parcial do risco, que é repartido com o segurado.

\section{Screening: Escrutínio promovido pela parte menos informada}

Esta é outro tipo de estratégia criada pelo mercado para combater efeitos nocivos da discrepância na distribuição da informação, que afeta a tomada de decisões dos agentes e acarreta distorções.

Se o contratante desinformado não receber sinalização, ou se os sinais transmitidos não forem confiáveis, resta-lhe recorrer ao screening, denominação atribuída por Spence $^{168}$, ao exame prévio promovido pelo contratante menos informado para conhecer melhor as qualidades do produto ou serviço ou os atributos da contraparte.

Signaling e Screening são estratégias de combate à assimetria informacional. A diferença fundamental entre elas, é que a primeira é iniciativa do contratante mais informado que tem interesse na identificação da boa qualidade de seu produto e serviço, para destacá-lo dos demais no mercado, e a segunda, incumbe ao contratante menos informado, que adota providências para descobrir as informações relevantes a respeito do contrato que se dispõe a celebrar. O exemplo de screening sempre lembrado é o contrato

\footnotetext{
${ }^{165}$ SHAVELL, Steven. op. cit., p. 541-562.

${ }^{166}$ Relação ótima de seguros de danos apresenta sempre uma tabela de descontos que associados ao moral hazard, para coibir o oportunismo. HOLMSTROM, Bengt. op. cit., p. 74-91.

${ }^{167}$ MACKAAY, Ejan; ROUSSEAU, Stéphane. op. cit., p. 127.

${ }^{168}$ SPENCE, Michael. Job market signaling, cit., p. 35-374.
} 
de experiência, de caráter temporário, em que o empregador pode oferecer ao candidato ao emprego um salário mais baixo, eventualmente incompatível com as propaladas qualidades deste, e durante o período de experiência, conferir o desempenho do empregado, a um custo mais baixo.

Mas esta estratégia é adotada também em vários outros setores da economia. Os bancos, por exemplo, precisam avaliar previamente o risco de inadimplemento, analisando a ficha cadastral dos tomadores de recursos, examinando seu patrimônio, possíveis garantias, renda mensal e sua origem, a finalidade do empréstimo pretendido, e todas as informações que lhes permitam aquilatar a disposição e a disponibilidade dos potenciais contratantes de restituir o empréstimo no prazo e condições avençadas ${ }^{169}$.

No mercado de seguros, além das formas de repartição de riscos com os segurados (como franquia e descoberta obrigatória), as seguradoras formulam questionários com o objetivo de obter informações fidedignas a respeito do risco ${ }^{170}$.

\section{Considerações finais}

Todas as instituições aqui analisadas se reportam a situações em que a confiança é fundamental, como advertiu Akerlof, no seu estudo pioneiro do modelo econômico

\footnotetext{
${ }^{169} \mathrm{O}$ Poder Público e alguns setores da sociedade às vezes dificultam o legítimo exercício do direito do contratante de obter informações a respeito das contrapartes, como ocorreu em relação ao cadastro positivo, que levou anos para ser aprovado. Esta demora não se deveu somente ao trâmite de aprovação do projeto de lei, mas também aos movimentos de entidades supostamente protetivas dos direitos dos consumidores, que alegavam, além da invasão de privacidade, a eventual discriminação de tomadores de empréstimo, e outras razões que, na verdade, desviam a propalada proteção do foco que deveria ter. O cadastro positivo é um indicador útil, porque, quem tem restrições bancárias não usa cheques nem cartões de crédito, e, portanto, não apresentaria ocorrências negativas, de modo que o cadastro negativo não seria apto a indicar sua real situação no mercado de crédito. A alegada discriminação do mau pagador não passa de consequência direta de sua própria conduta, e não lhe conceder crédito nada mais é do que o regular exercício do direito da instituição financeira, além de ser um eficiente redutor dos custos de transação representados pela dificuldade de recuperação do crédito a ele concedido e o maior risco de inadimplemento. E a dita proteção do consumidor não protege de fato a coletividade dos consumidores, pois prestigiar o mau pagador equivale a punir todos os bons pagadores, que arcarão com os custos gerados pelos inadimplentes, com a manutenção de elevadas taxas de juros, que provocam o fenômeno da seleção adversa. Esta é apenas mais uma amostra da exacerbação distorcida e equivocada dos direitos subjetivos induzida pelo cacoete ideológico do nosso ambiente institucional.

${ }^{170}$ Esse exercício de busca de informações (screening) que são extraídas da contraparte exige investimento de recursos, (tempo, trabalho, dinheiro), e representa custos de transação. A compreensão da finalidade e da utilidade desses processos de screening, no contexto do seguro, serve para mostrar que respostas omissas ou distorcidas ao questionário da seguradora, por exemplo, deveriam ser objetivamente punidas como violação da boa-fé, que é padrão supostamente objetivo de conduta. Mas, ironicamente, para caracterizar quebra do dever de boa-fé, impõe-se à seguradora o ônus de provar a má-fé do segurado, anulando a utilidade do questionário, esse importante instrumento de mensuração de riscos, providência inerente e indispensável à atividade securitária.
} 
caracterizado pela assimetria informacional. E informação é o substrato da confiança e da lealdade contratual, que são feições da boa-fé.

A par das soluções instituídas pelo mercado para resolver os problemas decorrentes da disparidade informacional e causadores de desequilíbrio no mercado, há instituições jurídicas, que, se bem elaboradas e aplicadas, criarão incentivos para induzir confiança, reduzir os custos de transação, e cumprir os demais objetivos do Direito. 


\section{CAPÍTULO 3. ASSIMETRIA INFORMACIONAL E AS INSTITUIÇÕES: REGIME DA INFORMAÇÃO NOS CONTRATOS}

\section{Regras básicas de distribuição do ônus da informação entre os contratantes}

As partes celebram contratos na expectativa de auferir benefícios recíprocos. Como o contrato é um instrumento que garante a livre e regular circulação de riqueza, atribui obrigações e reparte riscos, é indispensável que os contratantes tenham informações relevantes a respeito da operação econômica subjacente para poderem avaliar os riscos do negócio, e as reais possibilidades de ganho que o contrato lhes oferecerá. Daí cogitar-se do dever de informar ainda na fase de formação do contrato.

Duas regras fundamentais orientam o regime de distribuição da informação em matéria contratual. A prevalência de uma sobre a outra depende de circunstâncias inerentes ao ambiente institucional ao qual se aplicam, ou das situações a que concernem.

A primeira, segundo a qual cada um deve arcar com os ônus da obtenção das informações que lhe interessam, corresponde ao dever de informar-se, ${ }^{171}$ que se traduz pelo aforismo caveat emptor, que desloca do vendedor para o comprador o risco da informação relativa ao negócio. Até meados do século XV, época em que a sociedade sofria forte influência religiosa, o comércio era socialmente aceito apenas na medida em que servia ao bem da coletividade ${ }^{172}$, submetendo-se a estrita regulação, que impunha ao vendedor zelar pelos direitos do comprador (caveat venditor). ${ }^{173}$ Com o declínio do feudalismo e o florescimento do comércio, então liberto da filosofia vigente na sociedade medieval, e o crescente prestígio da classe comerciante na Idade Moderna, cedeu-se mais liberdade à atividade comercial, transferindo-se ao comprador a responsabilidade que antes recaía exclusivamente no vendedor.

A máxima caveat emptor, que resume a regra de que ao comprador incumbe verificar, avaliar e julgar, por seus próprios meios, o bem objeto da aquisição, estendeu sua

\footnotetext{
${ }^{171}$ Leia-se ônus de informar-se, pois implica a tomada de providência em benefício próprio, sob pena de não auferi-lo. É diferente de dever, porque em relação ao ônus, o beneficiário é o próprio agente, e o descumprimento só o priva da vantagem que o cumprimento lhe propiciaria.

${ }^{172}$ LEVINESS, Charles T. Caveat emptor versus caveat venditor. Maryland Law Review, v. 7, n. 3, p. 179, Apr. 1943.

${ }^{173}$ HAMILTON, Walton, H. The ancient maxim caveat emptor. Yale Law Journal, v. 15. n. 8. June, 1931. p. 1136.
} 
aplicação a outros tipos contratuais, se presentes as condições que a autorizassem. Conhecida no direito anglo-saxônico pela tradução let the buyer be aware, se ampliou abrangendo outros agentes (let the actor be aware).

A segunda regra, que impõe o dever de informar, se aplica às hipóteses em que a assimetria de informação aumenta desproporcionalmente os custos de transação e comporta correção. Essa regra se baseia principalmente em dois critérios para distribuir entre as partes o dever de informar. Partindo da premissa de que geralmente o contratante mais bem informado é o que melhor pode evitar a transmissão errônea da informação e eventualmente até o erro proveniente da percepção distorcida da realidade pela contraparte contratual (cheapest cost avoider), encarrega-o do dever de informar, ou, dependendo das circunstâncias, desloca o ônus ao contratante presumivelmente apto a suportá-lo ao menor custo (cheapest cost bearer). Esta distribuição nem sempre é boa, pois poderá representar um estímulo à distorção ou ocultação da informação por aquele que teria mais condições de evitá-la (cheapest cost avoider), quando ele não é o cheapest cost bearer. O problema surgirá sempre que, na aplicação da lei, esse ônus for atribuído, sem cogitar de que incentivos a lei deve gerar, àquele que supostamente teria mais recursos (deepest pocket) para arcar com os custos da desinformação ${ }^{174}$.

Existe uma relação de tensa bipolaridade entre a proteção do direito da parte mais bem informada se prevalecer da apropriação da informação, e a imposição do dever de informar. A dificuldade de escolha entre as duas opções reside não só no custo da informação, mas também no benefício que ela poderá representar a cada um dos contratantes, e qual deles faria jus ao benefício e a qual deve ser imputado o custo.

A distribuição dos ônus da informação, na aplicação da lei ao caso concreto, afetará não apenas as partes do contrato ao qual concerne o provimento jurisdicional, mas indiretamente, a todas as relações jurídicas futuras, pois, este efeito de segunda ordem das decisões judiciais influenciará a conduta dos contratantes, incentivando, ou não, a lealdade, a confiança recíproca, a cooperação e o comprometimento das partes. Este fator, concernente às externalidades ${ }^{175}$ geradas por decisões judiciais, exacerba a importância da

\footnotetext{
${ }^{174}$ Os equívocos nessa distribuição dos ônus da informação, que serão analisados oportunamente, são muito comuns na aplicação da lei aos contratos de seguro, em que a jurisprudência não distingue as situações em que se aplica uma ou outra regra, e frequentemente opta pela solução simplista, escolhendo a seguradora, por presumi-la como o cheapest cost bearer, a partir da premissa do deep pocket.

${ }^{175}$ Externalidades são efeitos projetados a terceiros, que não são partes na relação que os produziu, no caso, nem na relação processual, nem na material a ela subjacente. Em se tratando da atividade jurisdicional, esses efeitos são os incentivos negativos gerados, à sociedade toda, por decisões equivocadas.
} 
escolha dos critérios que devem nortear a elaboração e a aplicação da lei à informação que permeia a contratação.

As regras aqui abordadas constituem fundamentos subjacentes ao regime jurídico da informação no âmbito do direito contratual, que serão examinados em relação a alguns dos principais institutos atinentes à matéria, como vícios de declaração que maculam o negócio jurídico, o vício redibitório, e a boa-fé, especialmente sob os aspectos relacionados ao dever de informar, que está no foco deste trabalho.

A abordagem dos referidos institutos jurídicos se justifica, neste contexto, porque as situações fáticas a eles subjacentes guardam muita similaridade com as situações criadas pela assimetria informacional na formação dos contratos de seguro, em função de eventuais omissões e falsidades das declarações dos proponentes. Embora as peculiaridades do contrato de seguro e o mecanismo da operação subjacente, que exigem a máxima boa-fé e absoluta veracidade, recomendem tratamento mais severo da disparidade de informação, a análise do regime daqueles institutos revela os critérios adotados, permitindo inferir algumas ilações sobre a disciplina da assimetria informacional no âmbito contratual, úteis para a posterior análise da matéria nas relações de seguro privado.

\section{Linhas gerais da disciplina da informação relativa aos contratos}

A abrangência deste tópico, que examinará o erro, o dolo, os vícios redibitórios, a boa-fé, a teoria da aparência e o dever de informar, foi circunscrita aqui apenas aos institutos diretamente relacionados à questão da informação, cujo estudo possa, de alguma forma, contribuir para a abordagem da assimetria informacional nos contratos e, especialmente nas relações de seguro privado. Por isso, a despeito do aspecto multifacetado da boa-fé, serão analisadas apenas suas versões diretamente relacionadas com a questão da informação, a fim de manter o foco direcionado ao tema do trabalho. Portanto, a discussão ora encetada não analisará as acepções da boa fé relacionadas ao abuso de direito, e à ruptura injustificada das negociações pré-contratuais, e a outros institutos que apenas incidentalmente poderiam ser conectados ao tema da informação. 


\section{Erro}

A disparidade de informação pode decorrer de falta de percepção ou de apreensão distorcida da realidade pelo próprio contratante mal informado. Dependendo do caso, configurará o que a lei brasileira designa erro ou ignorância ${ }^{176}$. O Código Civil os equipara, embora tenham significados distintos. Mas a equiparação legal afasta o interesse jurídico da distinção. ${ }^{177}$

Erro de fato é vício do consentimento apto a invalidar o contrato, se concernente à natureza do negócio, à identidade do objeto principal da declaração, ou a alguma das qualidades a ele essenciais; ou à identidade ou qualidade essencial da pessoa a quem se refira a declaração de vontade. Mas o defeito só será apto a afetar a validade do negócio jurídico, se tiver influído no consentimento de modo relevante, ou seja, se ficar evidenciado que a parte não se teria obrigado se não tivesse incorrido em erro.

Erro de direito, ou seja, ignorância ou percepção distorcida da norma jurídica ${ }^{178}$, também é vício apto a invalidar o contrato, se for seu único ou principal móvel, e desde que não implique recusa à aplicação da lei. Por isso, em tese, não desafia o princípio de que ninguém se desobriga por desconhecimento da lei, mas o pressupõe.

Analisando o regime jurídico do erro no direito italiano, Roppo afirma que a tutela do erro se deve à observância do princípio da autonomia privada, pois se o contrato vincula as partes que voluntariamente se obrigam, não se pode considerar voluntária e consciente a assunção do vínculo, se o processo de avaliação e decisão for viciado por uma percepção errônea. ${ }^{179}$

Como são funções precípuas do Direito incentivar a circulação de riquezas por meio das operações econômicas e garantir a segurança jurídica, assegurando o cumprimento dos contratos, a tutela do erro deve ser restritiva, como exceção, sob pena de

\footnotetext{
${ }^{176}$ Arts. 138 a 144 CC.

${ }^{177} \mathrm{~A}$ ignorância se caracteriza pela ausência de qualquer ideia a respeito de pessoa ou objeto, e erro corresponde à substituição de uma ideia por outra falsa acerca de pessoa ou coisa WINDSCHEID, Bernardo. Diritto delle Pandette, p. 313, § 78, nota 1. Segundo Caio Mário, erro consiste na "deformação do conhecimento relativamente às circunstâncias que revestem a manifestação de vontade" e "ignorância importa o desconhecimento do que determina a declaração". (PEREIRA, Caio Mário da Silva. Instituições de direito civil. Atualização de Maria Celina Bodin de Moraes. 20. ed. Rio de Janeiro:Forense, 2004. v. 1, p. 517).

${ }^{178}$ Carvalho Santos, invocando a orientação de Pontes de Miranda, aponta a dificuldade de distinção entre o erro de fato e o de direito, asseverando que "a certos fatos correspondem certas relações jurídicas: se o erro recair nestes fatos, é de fato; se são conhecidos os fatos, e o que se ignora é a eficácia que a lei lhes atribui, é de direito o erro." CARVALHO SANTOS, J. M. Código Civil brasileiro interpretado: parte geral. 13. ed. Rio de Janeiro: Freitas Bastos, 1933. v. 2, p. 296.

${ }^{179}$ ROPPO, Vincenzo. Il contratto, cit., p. 780-781.
} 
estimular a imprudência e a negligência na condução dos negócios e instaurar insegurança jurídica.

Por isso, para que comporte proteção e justifique a sanção legal, é necessário que se trate de erro substancial sobre aspecto essencial do contrato, e que tenha influído no consentimento. A lei não exige a escusabilidade do erro como requisito para sua caracterização. ${ }^{180}$ Inspirada na fonte italiana, a legislação brasileira exige que o erro substancial seja reconhecível mediante normal diligência. ${ }^{181} \mathrm{O}$ erro se considera reconhecível, quando, em relação ao conteúdo, às circunstâncias do contrato ou mesmo à qualidade dos contraentes, uma pessoa de ordinária diligência teria podido notá-lo (art. 1431 do Código Civil italiano). A dispensa do requisito da escusabilidade e a exigência do requisito da recognoscibilidade, se inspiram "alla duplice considerazione del comportamento del dichiarante e di quello del destinatario" ${ }^{182}$. Distribuir o risco decorrente de falha de percepção tanto ao declarante que incidiu no equívoco, como ao destinatário, em vez de impô-lo exclusivamente àquele, teria o objetivo de estimular a confiança e a cooperação entre as partes.

\footnotetext{
${ }^{180}$ Diante da controvérsia instalada na doutrina em relação ao pressuposto da escusabilidade do erro, que, embora não fosse expressamente exigido por lei, era aceito pela doutrina estrangeira, e também pela brasileira na vigência do Código anterior, Pontes tece críticas percucientes, sustentando a irrelevância da escusabilidade do erro. PONTES DE MIRANDA, Francisco Cavalcanti. Tratado do direito privado: parte geral. 4. ed. São Paulo: Ed. Revista dos Tribunais, 1984. t. 4, p. 309-316. A jurisprudência ainda oscila em relação a esta questão, que, a nosso ver, ficou superada pela exigência da recognoscibilidade. Mas apesar de se terem firmado enunciados a respeito da irrelevância da escusabilidade do erro, como os do Centro de Estudos Judiciários do Conselho da Justiça Federal e do Superior Tribunal de Justiça, ainda há decisões equivocadas, como STJ, 4 ${ }^{\text {a }}$ Turma, R. Esp. 744.311, Rel. Min. Luís Felipe, j. 19.8.2010, DJ 09.9.2010.

${ }^{181}$ No direito italiano os requisitos do erro apto a anular o contrato também são a essencialidade e reconhecibilidade (art. 1428).

${ }^{182}$ Rodolfo Sacco explica a escolha da legislação italiana, que se supõe comum ao legislador brasileiro: "Il problema dell'errore inescusabile riconoscibile è quindi il problema del rilievo comparativo dell'assunzione di rischio da parte del dichiarante, della colpa del dichiarante, e di quella del destinatario. Se il legislatore avesse reputato prevalente la colpa del dichiarante, per coerenza avrebbe spogliato l'errore di ogni rilevbanza finché non sussista la mala fede (la riconosciutezza concreta dell'errore medesimo); oppure, avrebbe dovuto graduare la valutazioe delle colpe in um modo più articolato, distinguendo le colpe lievi da quelle gravi; avrebbe ciò̀ fatto soccombere l'errante in colpa grave rispetto alla contraparte in colpa lieve, e avrebbe mantenuto la soccombenza del destinatario della dichiarazione quando le colpe abbiano pari intensità. Il legislatore há invece deciso di considerare il dichiarante sempre responsabile e sempre esposto al rischio della dichiarazione imprudente; e di flettere questa sua responsabilità quando il destinatario non meriti protezione”. SACCO, Rodolfo; DE NOVA, Giorgio. Il contratto. 3. ed. Torino: UTET, 2004. v. 1, p. 502. (Collana: Trattato di diritto civile). ROPPO argumenta que "Ratio della riconoscibilità è la tutela dell'affidamento di chi riceve la dichiarazione basata sull'errore: non si vede perché accordare siffatta tutela a chi essendo consapevole del vizio, per definizione non può esibire il proprio affidamento; e, omettendo di avvertire controparte, ha violato il principio di buona fede precontrattuale (art. 1337). Del resto, un siffatto atteggiamento della parte si situa ai confini col dolo, nela variante di dolo omissivo o reticenza.” ROPPO, Vincenzo. Il contratto, cit., p. 804.
} 
Dolo $^{183}$

Outra hipótese de falha informacional prevista pela legislação brasileira é a da ocultação ou distorção intencional de informação pela contraparte, sem a qual o contrato não teria sido celebrado.

Não cogita a lei do chamado dolus bonus, consistente na exacerbação das qualidades do bem objeto da troca ou das condições do negócio, na medida em que é inerente a toda negociação e é insuscetível de ludibriar uma pessoa medianamente sagaz.

A proteção legal tem em mira o ato que, por meio de ardil, distorção ou ocultação maliciosa da verdade, induz a contraparte a celebrar um contrato com uma percepção errada da realidade. Aqui o erro não é espontâneo como na figura anterior, mas é induzido por outrem, em geral, o outro contratante ${ }^{184}$.

Para ser apto a invalidar o negócio jurídico, o vício deve decorrer da distorção ou da omissão de informações essenciais e ser determinante da declaração de vontade. $O$ dolo acidental, que não influi diretamente na realização do negócio, que se teria realizado por outro modo, dá ensejo apenas à reparação de perdas e danos, porque dolo também constitui um ilícito.

O silêncio a respeito de informação concernente a fato relevante que a outra parte ignore, embora tivesse o direito de saber, ${ }^{185}$ constitui omissão dolosa, sempre que, se não fosse por esta, o negócio não teria sido celebrado, ou teria sido concluído em bases diversas. Se o silêncio não configurar omissão apta a invalidar o contrato por dolo, poderá dar ensejo à anulação por erro, se preenchidos os requisitos legais pertinentes, ou, ainda, à eventual indenização.

A prova do dolo, por comissão ou omissão, incumbe ao prejudicado. Mas, conquanto a má fé, em princípio, não se presuma, pode ser provada até mesmo por

\footnotetext{
${ }^{183}$ Arts. 145 a $150 \mathrm{CC}$.

${ }^{184}$ A lei brasileira prevê também o dolo de terceiro, que autorizaria a anulação do contrato, se a parte a quem aproveite dele tivesse ou devesse ter conhecimento. Ainda que subsista o negócio, o terceiro estará sujeito a indenizar o prejudicado, em razão da prática do ilícito.

${ }^{185}$ Os critérios para que a ignorância da parte credora da informação seja considerada justificada, e os limites de seu direito de recebê-la da contraparte, bem como os correspondentes limites do dever de informar serão abordados ao longo deste capítulo, e oportunamente, quando se apresentarem os critérios da análise econômica e sua crítica.
} 
presunções, desde que associadas a indícios, além dos outros meios legalmente previstos. $^{186}$

Analisando a tensão entre a imposição do dever de informar e a proteção do direito da parte mais bem informada se prevalecer do sigilo, Roppo aborda o problema de uma perspectiva convergente com a análise econômica, mostrando que existe um trade-off $f^{87}$ entre as duas soluções jurídicas, pois o benefício de uma corresponde ao custo da outra e vice-versa, o que recomendaria a ponderação dessas soluções conflitantes.

Vale a pena resumir aqui seu raciocínio. ${ }^{188}$ Ele observa que as orientações normativas das quais partem os intérpretes, referindo-se à lei e à jurisprudência italianas, não são unívocas.

Argumenta que não se pode considerar a norma que prescreve a anulação do contrato de seguro por omissão de informação do segurado ${ }^{189}$, como expressão de um princípio geral, dado seu caráter de norma ditada exclusiva e excepcionalmente para um específico tipo contratual. Mas a multiplicação de regras especiais, como esta, que impõem deveres de informação à contraparte em um determinado tipo contratual, além de sua aplicação específica, deixa entrever uma tendência geral do sistema jurídico, que também serve de orientação para o intérprete.

Assevera que a norma de alcance geral concernente à reticência ${ }^{190}$ responsabiliza aquele que omite à contraparte informação que constitua causa da invalidade do contrato, mas essa regra diz respeito à responsabilidade do contraente e não à invalidade do negócio jurídico.

A jurisprudência italiana também não serve de orientação, segundo Roppo, porque oscila entre a adoção da relevância do dolo omissivo como princípio, e o aumento do rigor na análise dos requisitos de admissibilidade, em cada caso concreto ${ }^{191}$, sem indicar com precisão quais seriam tais exigências.

\footnotetext{
${ }^{186}$ PONTES DE MIRANDA, Francisco Cavalcanti. Tratado do direito privado: parte geral, cit., t. 4, p. 343. CARVALHO SANTOS, J. M. op. cit., p. 335-336.

${ }^{187}$ Essa expressão emprestada da Microeconomia corresponde às implicações entre eventuais perdas e ganhos envolvidos no processo de escolha.

${ }^{188}$ ROPPO, Vincenzo. Il contratto, cit., p. 816-817.

${ }^{189}$ Art. 1892 CC italiano.

${ }^{190}$ Art. 1338 CC italiano.

${ }^{191}$ Aqui me parece lógico este movimento da jurisprudência italiana, porque existe relação de causa e efeito entre a adoção de regra mais severa e a exigência de requisitos mais rigorosos para sua aplicação. Não se trata, a nosso ver, de tendências conflitantes da jurisprudência, mas de relação causa-consequência. Com efeito, quanto mais severa a sanção, mais rigorosa é a apreciação dos requisitos para a subsunção do caso
} 
Roppo observa que a fórmula corrente pela qual a reticência configura dolo quando constitui violação de um dever de informação, não resolve o problema, porque suscita outra questão logicamente antecedente à apreciação da violação de um dever, que é quando ele deve ser imposto.

Para Roppo a resposta implica a busca do justo equilíbrio entre interesses contrapostos, que ele pondera analisando os prós e os contras, numa análise consequencialista, de cada uma dessas escolhas que o regulador enfrenta.

De um lado, reconhece que é justo tutelar a parte lesada por um contrato que não teria sido celebrado, se a contraparte, em vez de silenciar, a tivesse informado: condição que induz a ampliar e intensificar os deveres de informação, admitindo que esta parece ser a linha da evolução do ordenamento jurídico ao equacionar o fator interpretativo e o legislativo. $O$ primeiro corresponde à crescente valorização na doutrina e na jurisprudência, do princípio da boa-fé, contratual e pré-contratual, vista como criadora de deveres, em situações que, no passado, se concebiam como terreno da liberdade e da imunidade, como fonte da obrigação de divulgar a informação, nos casos em que antes se reconhecia a faculdade de silenciar. $O$ fator legislativo é a multiplicação de normas inspiradas na transparência, que impõem deveres de informação verdadeira e clara à contraparte. Essas normas legais têm, em si mesmas, o valor sistemático de indicar, além dos específicos casos a que se aplicam, uma tendência geral do sistema jurídico.

Por outro lado, Roppo também percebe a necessidade de promover, por meio da aplicação da lei, uma eficiente e racional alocação de recursos e de riscos, demonstrando que a análise tradicional do direito também pode e deve focalizar a eficiência na disciplina dos institutos jurídicos. Nesta perspectiva, ele adverte que se deve evitar premiar a ignorância e a indolência de quem espera passivamente as informações da contraparte, as

concreto à hipótese legal, ainda que tais requisitos sejam os mesmos exigidos no caso da sanção mais branda. Por isso é que cominar a possibilidade de anulação do contrato por omissão de informação, por exemplo, pode se revelar contraproducente, pois a exigência de requisitos mais rigorosos para o enquadramento do caso concreto na moldura legal acabará restringindo as hipóteses de aplicação da lei. Esta tendência de aumentar o rigor na apreciação dos requisitos de admissibilidade da reticência como fundamento de invalidade do contrato tem duas outras consequências: $1^{\circ}$ ) descaracterizado o dolo se não demonstrada a omissão da informação, ainda resta a possibilidade de configuração de erro espontâneo da contraparte, que, em tese, também seria fundamento para a invalidade de negócio jurídico; e $2^{\circ}$ ) inviabilizada a caracterização da omissão dolosa como vício apto a anular o contrato, em razão da maior exigência quanto aos seus requisitos de admissibilidade, resta a possibilidade de punir o dolo como acidental, operando como ato ilícito. Mas nenhuma das duas situações resolve o problema da disciplina do dever de informar, que implica em delimitar as situações em que seria exigível, cominando-lhe sanções compatíveis com as consequências da omissão da informação e com a relevância desta em relação à natureza e ao objeto do contrato. 
quais poderia e deveria buscar por si mesmo. É preciso também defender a parte detentora da informação da exigência informativa exagerada e injusta da contraparte: especialmente quando aquela tenha tido que arcar com custos econômicos ou investimento de empenho pessoal (estudo, pesquisa) ${ }^{192}$. Conclui que aquele que pagou ou trabalhou para obter a informação não deveria ser compelido a presenteá-la à contraparte. No limite, questiona até em que medida seria justo obrigar alguém a compartilhar com outros a informação obtida por puro acaso, contestando, nessa medida, a teoria de Kronman ${ }^{193}$.

Constata, então, duas tendências contrapostas: uma a impelir à ampliação dos deveres de informação e, em consequência, a uma mais extensiva assimilação da reticência ao dolo, e a outra a pressionar na direção contrária. Incumbe ao intérprete encontrar, caso a caso, o justo equilíbrio entre elas. ${ }^{194}$

Para tanto, conclui que se devem sopesar as circunstâncias de cada caso concreto: os deveres de informação serão mais ou menos intensos, invocando-se ou não a omissão como fundamento da anulação do negócio jurídico, conforme o contrato seja padronizado ou individualizado, impessoal ou intuitu personae, previamente negociado ou não, entre pessoas estranhas ou já relacionadas entre si, entre partes com conhecimento e capacidade equivalentes em relação à matéria do contrato ou com diverso grau de conhecimento e competência, que entende como assimetria informacional.

Embora seu método seja o da análise tradicional, a preocupação de Roppo com a eficiência da alocação de recursos e sua percepção da função das normas como indutoras de comportamento revelam afinidade com a análise econômica do direito. A orientação do jurista italiano corrobora a ideia de que a perspectiva dessa escola constitui mais uma visão do sistema jurídico, a qual não prescinde da análise tradicional, como esta não deveria prescindir da abordagem econômica, pois ambas se complementam e são, por isso, reciprocamente dependentes.

Roppo focaliza algumas hipóteses em que a lei deve adotar como regra o dever de informação, todas elas convergindo para o contrato por adesão, técnica de contratação pela qual uma das partes predispõe as cláusulas gerais e uniformes que pautarão o contrato, e a

\footnotetext{
${ }^{192}$ Esta é, como se verá, uma apreciação típica da análise econômica.

${ }^{193}$ Os critérios propostos por Kronman para a disciplina da informação serão abordados no capítulo 5.

${ }^{194}$ Neste aspecto, cabe uma ressalva. Embora o critério de distribuição do ônus da informação seja, em última análise, decidido casuisticamente, a lei deve fornecer orientação tão segura quanto possível para que sua aplicação não dê margem a estapafúrdias e até antagônicas interpretações, contribuindo para aumentar a imprevisibilidade das decisões judiciais e, consequentemente a insegurança jurídica. Isto representa uma inversão da função do Direito, que acaba incentivando paradoxalmente o efeito que deveria coibir.
} 
outra adere a elas sem poder discuti-las. Com efeito, a padronização, a impessoalidade, a falta de negociação prévia, e a diferença de conhecimento em relação ao conteúdo do contrato são todas características do contrato por adesão. Embora Roppo se tenha referido a elas como hipóteses não cumulativas, dificilmente elas aparecerão isoladamente em contratos diferentes. E, de um modo geral, o Direito já cuidou dessas hipóteses ao dispensar especial proteção aos casos em que uma das partes é juridicamente mais vulnerável, o que se traduz pelo reduzido poder de barganha e pela assimetria informacional, embora esta não atinja apenas o consumidor ou o aderente.

A análise de Roppo não é abrangente, e nem se propôs a sê-lo. Mas foi aqui destacada porque, com sua acuidade habitual, aponta um caminho sintonizado com a perspectiva econômica, embora comporte complementação. Esta questão será retomada em outro capítulo, em que se sugerirão critérios aplicáveis à distribuição dos ônus e riscos da informação, e se abordará a necessidade de proteção do agente que não tem acesso à informação de que dependem a eficiência e o equilíbrio do contrato.

\section{Vício Redibitório ${ }^{195}$}

É o defeito oculto da coisa objeto da prestação em um contrato comutativo, e que autoriza sua devolução ou o abatimento no preço, se a tornar imprópria ao uso a que se destina, ou lhe diminuir o valor.

Decorre do princípio de que o vendedor deve fazer boa a coisa vendida e funciona como garantia, independente da prévia ciência do defeito pelo alienante. Se o vício não era de seu conhecimento, a redibição do contrato acarretará apenas a devolução do preço, mas se o alienante o conhecia, também responderá por perdas e danos.

Poderá ocorrer, na prática, uma sobreposição de situações entre os vícios do consentimento (erro e dolo) e o redibitório: ${ }^{196}$ quando o alienante conhecia o vício e omitiu essa informação, o instituto pode se confundir com a omissão dolosa, e quando o alienante não o conhecia, pode caracterizar erro do adquirente. Porém, esses institutos se distinguem entre $\mathrm{si}^{197}$, não só por caracterizar-se o vício redibitório somente nos contratos

\footnotetext{
${ }^{195}$ Arts. 441 a 446 CC.

${ }^{196}$ SACCO, Rodolfo; DE NOVA, Giorgio. op. cit., v. 1, p. 540.

${ }^{197}$ CUNHA GONÇALVES invoca a diferença entre vício e defeito, sustentando a distinção entre os defeitos do negócio jurídico e os vícios redibitórios. Define vício como uma alteração no estado ou modo de ser da coisa, que lhe tira a normalidade de sua condição, e defeito é a falta de um elemento ou fator da coisa que a impede de existir no estado normal. GONÇALVES, Luiz da Cunha. Da compra e venda no direito
} 
comutativos, mas também porque este não afeta a essência da coisa objeto da prestação ${ }^{198}$, embora a torne inapta ao uso a que se destina ou diminua seu valor, por isso comporta medidas corretivas diversas do erro e do dolo.

O instituto também serve ao propósito de assegurar o equilíbrio das prestações e a efetiva voluntariedade das trocas econômicas, porque a escolha racional demanda conhecimento dos trade-offs envolvidos.

Como o contrato é meio de atribuição de obrigações e direitos entre as partes e de distribuição dos ônus decorrentes de eventuais riscos, sua eficiência depende da utilidade para ambos os contratantes. Nos contratos comutativos, o equilíbrio está na equivalência das prestações recíprocas, o que traduz para o direito a eficiência paretiana, como observa Mackaay ${ }^{199}$. Isto justifica a disciplina jurídica dos vícios redibitórios.

Mas a aplicação da lei ao caso concreto deverá levar em conta a necessidade de promover incentivos à cooperação e ao comprometimento das partes em relação ao cumprimento dos contratos, e evitar o eventual oportunismo das alegações de vícios que fundamentam ações declaratórias de indébito que atulham os tribunais e, na verdade, constituem meros pretextos para o inadimplemento das obrigações. Apesar de eventualmente identificáveis ictu occuli como falaciosas, tais alegações têm servido frequentemente de fundamento para concessão de liminares de sustação de protesto, o que, além de obviamente prejudicar o credor, por premiar o oportunismo do devedor, gera externalidades, repercutindo, em toda a sociedade, seus efeitos de segunda ordem, que disseminam a ideia de que o oportunismo compensa. As decisões judiciais que, por imperícia ou negligência, falham na percepção da realidade subjacente às alegações das partes, além de atribuírem injusta e ineficientemente o direito no caso concreto, estimulam tentativas de obtenção de vantagem indevida por meio dos processos judiciais, e, com isso, incentivam a seleção adversa dos jurisdicionados, que transformam o Poder Judiciário no guardião involuntário de interesses oportunistas. Para evitar esses efeitos de segunda ordem da distribuição de justiça é preciso apenas que o aplicador da lei se disponha a

comercial brasileiro. São Paulo: Max Limonad, 1950. n. 129. Defende a teoria da pressuposição como fundamento da responsabilidade do vendedor pela garantia da coisa vendida sob pena de redibição ou de abatimento de preço, afirmando que a pressuposição é uma condição não manifestada, e que o contratante pressupõe, com base na finalidade natural da coisa, sua aptidão para aquela destinação, o que afasta a hipótese de erro e dolo. Id. Ibid., n. 382.

${ }^{198}$ VIVANTE, Cesare. Trattato de diritto commerciale. Torino: Fratelli Bocca, 1905. v. 4, n. 1.647.

${ }^{199}$ MACKAAY, Ejan; ROUSSEAU, Stéphane. op. cit., p. 373. 
enxergar o eventual oportunismo do agente alegadamente mal informado, ou dos supostos vícios ocultos.

\section{Boa-fé}

Este trabalho dedica especial atenção à boa-fé, devido à sua estreita conexão com a informação no âmbito contratual.

A noção de boa fé tem raízes no direito romano. Desde a origem, assumiu diversas acepções dependendo do campo de sua aplicação. Menezes Cordeiro aponta os três prismas semânticos da boa fé: fides-sacra, de natureza religiosa, mas de conteúdo indefinido, pois suas manifestações, como a Lei das XII Tábuas e o culto à deusa Fides não permitem identificá-lo. A fides-facto, sem qualquer conotação moral ou religiosa, remete, segundo o autor, à noção de garantia, traduzida por confiança, lealdade, credibilidade. A fides-ética atribui à garantia uma conotação moral, implicando sentido de dever. ${ }^{200}$ Essa ideia de garantia se referia à lealdade e à adesão ao compromisso firmado, assegurando fidelidade à palavra empenhada.

A conotação de garantia foi atribuída à fidei inicialmente no âmbito dos negócios bilaterais consensuais, que, desprovidos da proteção processual do Estado, precisavam assegurar a reciprocidade das obrigações e o comprometimento das partes, como no comércio internacional. ${ }^{201}$ Assim nasceu a bona fides, como norma social, com função de assegurar a responsabilidade dos contraentes e vinculá-los ao leal adimplemento do contrato. $^{202}$

Anota-se aqui sua origem, na medida em que revela seu aspecto multifacetado, e também a função que lhe é atribuída até hoje, de garantia do comprometimento das partes, da vinculação destas às obrigações assumidas, que representa uma das mais relevantes

\footnotetext{
${ }^{200}$ MENEZES CORDEIRO, António Manuel da Rocha e. Da boa fé no direito civil. 3. reimpr. Coimbra: Almedina, 2007. p. 53-57.

${ }^{201}$ MARTINS-COSTA, Judith. A boa-fé no direito privado: sistema e tópica no processo obrigacional. 1. ed. 2. tir. São Paulo: Ed. Revista dos Tribunais, 2000. p. 114-117, passim.

${ }^{202}$ Esta feição da boa fé como indutor de confiança recíproca, independente da tutela jurídica do negócio, foi apontada por Betti: "Ora, o direito, quando se decide a elevar os contratos sob palavra, ao nível de negócios jurídicos, não faz mais do que reconhecer, em vista da sua função socialmente relevante, aquele vínculo que, segundo a consciência social, os próprios particulares já anteriormente admitiam existir nas relações entre eles. Não faz mais que reforçar e tornar mais sólido esse vínculo, acrescentando-lhe a sua sanção." BETTI, Emilio. Teoria geral do negócio jurídico. Trad. Fernando de Miranda. Coimbra: Coimbra Ed., 1969. t. 1, p. 90-91. Dependendo do grupo a que pertençam os agentes, as normas sociais podem ser mais eficientes do que a das regras jurídicas, impondo sanções eventualmente mais severas, como a exclusão daquele grupo ou mercado.
} 
expressões da boa-fé em matéria contratual, pois, antes de mais nada, agir de boa-fé é cumprir as obrigações pactuadas.

Ao longo do processo de expansão, a expressão fides, radicalmente associada a fidelidade, confiança e fé, foi conectada à ideia de justiça e muito usada como instrumento de retórica. $^{203}$

A boa-fé passou, então, a ser aplicada como recurso técnico da atividade pretoriana, e foi ganhando outros contornos virtualmente contraditórios, pois, de um lado, o instituto servia para assegurar a vinculação das partes ao pacto celebrado, e de outro, era invocado para excepcionar a obrigatoriedade do vínculo, quando se considerasse a exigência da contraparte contrária à boa-fé (exceptio doli).

A crescente diluição do significado da boa-fé, com a ampliação de seus limites denotativos e conotativos, propiciou sua utilização como instrumento de governos totalitários, como o fascismo e o nazismo, fundados no corporativismo, cuja proposta era submeter a iniciativa privada à consecução da justiça social, concentrando muito poder nas mãos do Estado. ${ }^{204}$ Embora a ideia de boa-fé não esteja indissoluvelmente associada aos dois regimes, ${ }^{205}$ o fato de ter servido a tal função, já evidencia que, pela extensão de sua imprecisão, se presta a interpretações antagônicas, que lhe podem trair a essência, revelando seu aspecto paradoxal.

Esse sintético traço evolutivo do instituto serve para demonstrar que a deturpação inicial de seu conteúdo se perpetuou ao longo da história. O uso impreciso e ambíguo do

\footnotetext{
${ }^{203} \mathrm{O}$ "alicerce da justiça é a boa fé, ou seja, a sinceridade nas palavras e a lealdade nas convenções" (...) CICERO, Marco Túlio. Dos Deveres. Trad. Alex Martins. São Paulo: Martin Claret, 2005. p. 37.

204 "Good faith implies a developed sense of community and a high level of awareness of personal responsibilities toward society. But despite these worthy moral qualities, the principle of good faith is very often viewed by legal scholars with suspicion. The expansion of the principle of good faith, the claim is repeatedly made, would open the door to social control, in particular that of a Fascist nature. If this fear seems exaggerated and irrational, it is owing to the association in many people's mind between the expanded good faith notion and the corporative political philosophy. (...) And while obviously good faith notions do not automatically lead to corporativism (...), studying the legal and ideological basis for good faith in the corporative state and in Fascism in general is essential for any discussion of the possibility of applying expanded notions of good faith in the modern world. (...) Both the Fascist regime in Italy and the Nazi dictatorship in Germany incorporated elements of corporativist ideal into their political philosophy. (...) While the Nazi legal system accepted the theory of good faith because of the ideological tenet of the community of the nation, it was the Italian Fascist corporative state that went the furthest along the road of incorporating this theory into its practical legal framework. (...) The official purpose of the corporative structure was the attainment of social justice. (...) The fetish of private initiative without social duties [has] definitely fallen. (...) One of the major (and to a degree understandable) objections to the corporative reestructuring of society and law it that it places an inordinate amount of power in the hands of the state". COLOMBO, Sylviane. Fascism, community, and the paradox of good faith. The South African Law Journal, v. 111, n. 3, p. 482-496, 1984.

${ }^{205}$ Id. Ibid., p. 484.
} 
princípio esvaziou seu significado, acarretando crescente fragilidade de contornos, e permitiu que fosse carregada de implicações emotivas, o que acabou redundando na mitificação da boa-fé. ${ }^{206}$

Não se pretende, com isso, sustentar a imprestabilidade desse princípio, que irriga todo o direito privado ${ }^{207}$, e é elemento basilar do contrato, pois a confiança que ele visa proteger é a pedra angular do sistema jurídico contratual ${ }^{208}$. Mas, com a argumentação a seguir desenvolvida, pretende-se circunscrevê-lo a um campo mais restrito, com a função residual de disciplinar situações que não se enquadrem nas regras coordenadas pelo princípio da boa-fé. Isto conferiria mais operacionalidade ao princípio, e mais objetividade à disciplina da informação, cuja autonomia permitiria distribuir melhor o ônus da informação nos contratos, e, especialmente nas relações de seguro privado.

A doutrina vislumbra na boa-fé um princípio geral, definindo-o como norma ${ }^{209}$ de caráter genérico e impreciso, que compreende e coordena regras mais objetivas, que são suas aplicações concretas. ${ }^{210}$ Também delineia padrões de conduta ${ }^{211}$, ditando modelo de atuação conforme a boa-fé e estabelece critérios de integração e interpretação dos contratos. Jaluzot conclui que a boa-fé é um recurso à disposição dos juízes, cuja missão é atribuir-lhe coerência, mas que, na França, tem sido invocado como fundamento de toda e

\footnotetext{
${ }^{206}$ MENEZES CORDEIRO, António Manuel da Rocha e. op. cit., p. 68-70 e p. 41.

${ }^{207}$ MACKAAY, Ejan; ROUSSEAU, Stéphane. op. cit., p. 382.

${ }^{208}$ SACCO, Rodolfo; DE NOVA, Giorgio. op. cit., v. 1, p. 238.

${ }^{209}$ Considera-se norma gênero do qual princípio e regra são espécies. Alexy explica que a diferença entre princípio e regra não é o grau de abrangência e generalidade daquele. Este não seria um traço distintivo, até porque há regras mais ou menos abrangentes, e, por isso, a diferença entre as duas categorias não seria apenas relativa à maior ou menor abrangência. O diferencial não é quantitativo, mas qualitativo, pois princípios são normas "que ordenam que algo seja realizado na maior medida possível dentro das possibilidades jurídicas e fáticas existentes. São, pois, mandamentos de otimização em face das possibilidades jurídicas e fáticas .(...) Já as regras são normas que são sempre ou satisfeitas ou não satisfeitas. Se uma regra vale, então deve se fazer exatamente aquilo que ela exige; nem mais nem menos." $\mathrm{O}$ autor esclarece que "regras, se válidas, devem ser aplicadas de forma tudo-ou-nada, enquanto os princípios apenas contêm razões que indicam uma direção, mas não têm como consequência necessária uma determinada decisão". Observa o autor que a colisão entre princípios se resolve pela lei do sopesamento, ou seja, da ponderação entre eles, e o conflito entre regras só se resolve pela exceção ou pela exclusão, porque se uma for válida, a que com esta colide será inválida. ALEXY, Robert. Teoria dos direitos fundamentais. Trad. Virgílio Afonso da Silva. São Paulo: Malheiros Ed., 2008. p. 92-93, p. 117 e p. 153. Essa diferença entre princípios e regras mostra que, como a objetividade das regras não comporta meio-termo, tendem a ser mais incisivas e abrir menos espaço a considerações valorativas na sua apreciação, o que contribui para a posição defendida ao longo deste capítulo a respeito da conveniência da instituição de regras de distribuição de informação autônomas em relação ao princípio da boa-fé, o que, com mais razão, se aplica ao contrato de seguro, pois sua característica de máxima boa-fé enfatiza o dever de transparência e veracidade, que nada mais é do que o dever de informar.

${ }^{210}$ JALUZOT, Béatrice. La bonne foi dans les contrats: étude comparative de droit français, allemand e japonais, Paris: Dalloz, 2001. p. 187.

${ }^{211}$ Para distinção entre princípio e padrão, v. JALUZOT, Béatrice. op. cit., p. 74-75.
} 
qualquer norma de direito contratual e extracontratual, o que contribui para indevida confusão de regras num amálgama abusivo. ${ }^{212}$

A tradução de boa-fé no Uniform Commercial Code, como "honesty in fact in the conduct or transaction concerned" também não permite decifrá-la ${ }^{213}$, porque, como a matriz, honestidade pertence à categoria moral, o que só contribui para arrastar a discussão para o domínio moral e ideológico ${ }^{214}$. E esse terreno da ideologia se tornaria solo fértil para críticas impregnadas da tradição individualista e liberal anglo-americana ${ }^{215}$.

A plurivocidade conceitual da boa-fé, agravada pelo fato de ser traduzida pela doutrina por termos tão vagos quanto seu próprio conceito, amplia demais o âmbito da discricionariedade judicial, criando incerteza jurídica. Uma das críticas que se faz ao princípio da boa-fé é justamente que aumenta muito o grau de discricionariedade na aplicação da lei, permitindo que o juiz o invoque nas mais diversas situações, com múltiplos e até antagônicos significados, sempre de acordo com seus próprios valores morais e ideológicos ${ }^{216}$. Embora se argumente que o julgamento baseado no princípio da boa fé se atém aos valores adotados pela sociedade, e não aos valores individuais de cada julgador, para preencher-lhe o sentido ${ }^{217}$, não é bem assim que funciona o processo de escolha dos agentes. Como vimos no capítulo anterior, a racionalidade humana é

\footnotetext{
${ }^{212}$ JALUZOT, Béatrice. op. cit., p. 537, § 1839.

${ }^{213}$ No direito anglo-americano, boa-fé se traduz por termos tão genéricos como honesty, fairness, fair conduct, fair dealing, decency, decent behavior, reasonableness, reasonable standards, ethical sense, spirit of solidarity, o que não contribui para delimitar o conceito de boa-fé, e muito menos operacionalizá-lo.

${ }^{214}$ COLOMBO, Sylviane. Good faith: the law and morality. The Denning Law Journal, v. 8, n. 1, p. 23-59, 1993.

${ }^{215}$ Id. Ibid., p. 24.

${ }^{216}$ Alexy assevera que princípio e valor não se confundem, embora apresentem muitas semelhanças entre si. Aponta a diferença entre eles, argumentando que, como mandamentos que são, princípios pertencem ao âmbito deontológico (do dever-ser), e valores, ao campo axiológico. (...) O modelo de princípios e o modelo de valores mostraram-se, na essência, estruturalmente iguais, diferenciando-se apenas em relação à sua pertinência a níveis distintos. ALEXY, Robert. op. cit., p. 153. Mas, assim como valores, princípios se regem pela lei do sopesamento, comportando ponderação no caso de conflito entre eles, para decidir pela prevalência de um deles. Isso se faz por meio de um processo de hierarquização e de ponderação, atribuindo-se valor aos princípios colidentes, classificando-os de acordo com o peso que lhes foi atribuído, para poder escolher entre eles. Uma das críticas que nos parece acertada em relação ao processo de decisão com base em princípios é da mesma ordem da objeção metodológica à ordenação de valores e sua ponderação em caso de colidência: "o sopesamento ficaria sujeito ao arbítrio de quem sopesa”. Alexy reconhece que "essas objeções são procedentes se com elas se quiser dizer que o sopesamento não é um procedimento que conduza, em todo e qualquer caso, a um resultado único e inequívoco. Mas elas não são procedentes quando daí se conclui que o sopesamento é um procedimento não-racional ou irracional." ALEXY, Robert. op. cit., p. 163. Embora o sopesamento seja um procedimento racional, também é certo que essa racionalidade é condicionada pelos valores incorporados pelo agente que faz a ponderação, e como se trata de juízo de valor, está mais sujeito à visão subjetiva do agente. Ao sopesar princípios, pessoas diferentes atribuirão pesos diferentes a cada princípio, de acordo com seus condicionamentos. $\mathrm{O}$ fato de fundamentar a decisão não parece mudar essa realidade, porque a relatividade do valor dos princípios permite, pelo menos em tese, que a fundamentação se lastreie em argumentos diversos e até antagônicos.

${ }^{217}$ MARTINS-COSTA, Judith. op. cit., p. 114-117, passim.
} 
condicionada por fatores endógenos e exógenos, que abrangem desde a aptidão intelectiva e as condições psicoemocionais, até os valores culturais, éticos, religiosos e ideológicos, os quais também condicionam a tomada de decisão. Se todos os agentes são influenciados por esse condicionamento, com os juízes não seria diferente. Portanto, afigura-se insustentável o argumento de que os tribunais interpretariam a boa-fé de acordo com os valores sociais, e não com valores individuais de intérprete e aplicador da lei. Ainda que por dever de ofício, ninguém se despoja da ideologia e demais valores assimilados a vida toda, durante longa sedimentação, como se eles não tivessem sido incorporados nesse processo de percepção e assimilação da realidade, que se resume no conhecimento. Por isso, é incontestável que a aplicação do princípio da boa-fé sempre implicará dose extraordinária de subjetividade, que tornará a decisão imprevisível, porque sujeita à apreciação de caráter mais pessoal do que técnico. Corroborando esta asserção, Zimmerman e Whitaker afirmam que, na prática, o reconhecimento de um princípio da amplitude da boa-fé por um sistema jurídico mais do que autoriza o juiz a decidir de acordo com a própria percepção da visão adequada do caso, instiga-o a fazê-lo. ${ }^{218}$

Portanto, ao conceder a cada juiz o direito de preencher o conteúdo do princípio da boa-fé de acordo com seus próprios valores morais e ideológicos, o sistema jurídico mina ainda mais a previsibilidade das decisões judiciais, contribuindo para a insegurança jurídica, que é justamente a antítese da função jurisdicional. Embora reconheça que a boafé, se usada parcimoniosamente, é uma categoria residual importante para limitar a liberdade contratual, no interesse de sua própria preservação, Farnsworth pondera que a dificuldade de definir até que ponto e em que medida se aplicaria o princípio da boa-fé, criaria incerteza, nada contribuindo para a evolução do regime jurídico contratual. ${ }^{219}$

Enfrenta-se aqui o confronto entre dois princípios, o da justiça contratual a que, primordialmente, serviria a boa-fé, e o da segurança jurídica. A prevalência de um sobre o outro não depende apenas das circunstâncias do caso concreto, mas principalmente da perspectiva ideológica pela qual se focalize essa questão, pois, na ponderação desses princípios, a atribuição de pesos a um e a outro decorre da maior valoração conferida a

\footnotetext{
${ }^{218}$ For in practice, the recognition of a principle of the breadth of good faith by a legal system does rather more than merely allow court to decide according to its perception of the proper view of the case; it invites court to do so. (grifos do original) ZIMMERMAN, Reinhard; WHITTAKER, Simon (Eds.). Good faith in European contract law. Cambridge: Cambridge University Press, 2000. p. 688.

${ }^{219}$ FARNSWORTH, E. Allan. Precontractual liability and preliminary agreements: fair dealing and failed negotiations. Columbia Law Review, n. 87, p. 217-294, Mar. 1987.
} 
cada um deles, de acordo com sua tabela de valores. Por isso é que se afirma que $o$ sopesamento fica sujeito ao arbítrio de quem sopesa. ${ }^{220}$

Além disso, atribuir mais poder discricionário aos juízes equivale a conferir mais poder ao Estado, e como distribuição de $\operatorname{poder}^{221}$ é jogo de soma zero, ou seja, um ganha na proporção em que o outro perde, quem sai perdendo são os próprios agentes econômicos e, por consequência, a autonomia privada. ${ }^{222}$ Aqui também transparece a ideologia dessa discussão: vale a pena conferir mais poder ao Estado? E até que medida a aplicação indiscriminada do princípio não afrontaria outro princípio moral básico, o da responsabilidade pelos próprios atos? A resposta oscilará de acordo com os valores incorporados e assimilados à racionalidade de cada um. ${ }^{223}$

A crítica de que a incerteza decorrente da imprecisão do conceito de boa-fé aumentaria os custos de transação, tem sido rebatida sob o argumento de que a amplitude e ambiguidade seriam aspectos positivos, e não negativos, porque serviriam como freios mais eficientes em relação às condutas maliciosas, reduzindo os custos de aplicação do princípio $^{224}$. Mas aqui parece haver um equívoco: as normas ambíguas não incitam mais respeito aos seus preceitos, justamente por lhes faltar a incisividade da certeza e, consequentemente, operacionalidade, o que é facilmente intuído pelos agentes, que também percebem as muitas brechas inerentes às fórmulas jurídicas ambíguas e elásticas. ${ }^{25}$ Se um princípio serve tanto para fundamentar a exigência de lealdade contratual e comprometimento com as obrigações assumidas, como também se presta a

\footnotetext{
${ }^{220}$ Vide nota 216.

${ }^{221}$ Poder é, em tese, indivisível, mas aqui é usado como metonímia do exercício do poder, que, como tal, pode ser objeto de divisão e de distribuição.

${ }^{222}$ Tratando da sobreposição entre os poderes de aplicação e os de elaboração da lei, Zimmermann e Whitaker cogitam da possível resistência de alguns tribunais que respeitam os limites de seu poder criativo, à adoção de princípios que, como a boa-fé, incitam o exercício da atividade legislativa pelo Judiciário, diante da inadequação de promover reformas legislativas por meio de decisões judiciais. ZIMMERMAN, Reinhard; WHITTAKER, Simon (Eds.). op. cit., p. 689.

${ }^{223}$ Kessler e Fine exprimem essa preocupação, relacionada à aplicação indiscriminada e exagerada do princípio da boa-fé: "Of course, there are real dangers in any overenthusiastic and indiscriminate embracing of good faith notions. Judicial intervention in the name of fairness must find its limit when it impinges too greatly on private autonomy. And a deterioration of the law of contract into "well-meaning sloppiness of thought" must be avoided so as not to disregard the fundamental moral principle of responsibility for one's own action. Nevertheless, good faith and culpa in contrahendo, used with restraint, are "residual" categories whose existence is vital to an open system of contract justice and to a restriction of contractual freedom in the interest of its own preservation. The law confronts the task, in the interest of certainty, of identifying and categorizing these amorphous 'residual' concepts, only to be faced with the realization that this process is never-ending." KESSLER, Friedrich; FINE, Edith. Culpa in contrahendo, bargaining in good faith, and freedom of contract: a comparative study. Harvard Law Review, n. 77, p. 401449, Jan. 1964.

${ }^{224}$ COLOMBO, Sylviane. Good faith: the law and morality, cit., p. 26.

${ }^{225} \mathrm{O}$ princípio geral daria ensejo a uma larga margem de discrição aos juízes e criaria uma grande incerteza para os contratantes. MENEZES CORDEIRO, António Manuel da Rocha e. op. cit., p. 240 e ss.
} 
justificar a ignorância inocente do agente em relação a determinado elemento ou circunstância relevante do contrato, não permitirá prever a decisão judicial na apreciação do caso. Como os contratos não cumpridos geralmente acabam no Judiciário, é imprescindível que haja possibilidade de prever o resultado da apreciação judicial, pois, os agentes tendem a observar regras ou padrões de comportamento legalmente prescritos ou a cumprir o pactuado, sob duas condições alternativas: ou porque lhes convém, ou porque a lei representa uma ameaça crível $^{226}$, compelindo-os a isso. Mas a ambiguidade do direito aplicável ao caso e a imprevisibilidade das decisões judiciais minam a eficiência e a autoridade da lei, pois se o descumprimento da obrigação não permitir antever claramente a probabilidade de punição, seu cumprimento passará a depender exclusivamente da conveniência ou do senso moral do devedor da obrigação. Esse efeito perverso compromete a função sancionadora e, por via reflexa, a função promocional do Direito. Isso gera desconfiança, contamina o mercado e reduz bem-estar social. Também por isso tantos autores têm tentado delimitar melhor o alcance e o significado da boa-fé aplicada ao Direito, na expectativa de torná-la mais operante.

Na tentativa de formular o sentido material da boa-fé, Menezes Cordeiro começa pela delimitação negativa do instituto, excluindo de sua abrangência a equidade, os bons costumes e a ordem pública, a culpa, a diligência e a função social e econômica dos direitos, como se desbastasse a construção dogmática para atingir-lhe o núcleo ${ }^{227}$. E conclui que a confiança ${ }^{228}$ resume a essência do conteúdo do princípio, e constitui uma ponte entre a boa-fé objetiva e a subjetiva ${ }^{229}$. Mas, segundo o autor, a proteção da confiança não esgota os vetores que informam a boa-fé. O outro princípio que a instrui é o da materialidade da regulação jurídica ${ }^{230}$. Neste papel, a boa-fé reforça a aplicação das

\footnotetext{
${ }^{226}$ Em Direito, ameaça remete a mal injusto, mas aqui esta expressão é usada na acepção que lhe dá a Teoria dos Jogos, que não identifica o elemento normativo injusto. A norma legal geralmente comina sanção a ser aplicada em caso de descumprimento, exatamente para surtir o efeito de modelar a interação humana. Quanto mais remota parecer a punição prevista para o comportamento que desvia da lei, menos eficiente será a norma.

${ }^{227}$ MENEZES CORDEIRO, António Manuel da Rocha e. op. cit., p. 1197. Nessa operação de redução dogmática da boa fé, o autor traça as feições de cada instituto indevidamente abrangido pelo dogma, e aponta as razões pelas quais não se justificam as aproximações feitas pela doutrina e pela jurisprudência entre aqueles institutos e a boa fé. Id. Ibid., p. 1197-1233, passim.

228، "Confiança exprime a situação em que uma pessoa adere, em termos de atividade ou crença, a certas representações passadas, presentes ou futuras, que tenha por efetivas". (...) "O princípio da confiança explicitaria o reconhecimento desta situação e a sua tutela". MENEZES CORDEIRO, António Manuel da Rocha e. op. cit., p. 1234.

${ }^{229}$ Id. Ibid., p. 1238.

${ }^{230}$ Id. Ibid., p. 1197 e p. 1252.
} 
normas constitutivas da situação fática, consubstanciando-as, ou complementando-as mediante a cominação de deveres de cuidado ou de lealdade. ${ }^{231}$

Whittaker e Zimmerman apontam algumas das principais aplicações da boa-fé no sistema contratual romano-germânico, que incluem culpa in contrahendo, dever de informar, lesão, abuso de direito, obrigação de lealdade na execução dos contratos, erro e dolo, comportamento contraditório, teoria da aparência, deveres fiduciários do administrador societário, e como critério de interpretação do comportamento dos contratantes e dos termos do contrato. ${ }^{232}$

Argumentando que a boa-fé assume muitos sentidos no discurso jurídico, de ignorância do vício que macula o título aquisitivo aliado ao cuidado tomado na sua análise, no direito das coisas, à lealdade no processo de contratação, Mackaay e Rousseau propõem que se busque, no regime de todos os conceitos que a boa-fé compreende, um mínimo denominador comum para caracterizar o instituto. À noção de boa-fé seria reservada função residual, que não seria invocada, senão excepcionalmente e como último recurso, para tratamento de iniqüidade que nenhuma outra instituição permitiria corrigir. ${ }^{233}$ Observando que a função precípua da boa-fé, seja como padrão de conduta, cláusula geral, ou princípio orientador da integração e da interpretação dos contratos, é o combate ao oportunismo, este seria o traço comum às diversas fórmulas de boa-fé, que se resumiriam, então, na ausência de oportunismo. ${ }^{234}$ Reduzir o princípio da boa-fé à sua aplicação residual, para disciplinar somente os casos não alcançados pelas demais regras em que se decompõe, contribuirá para sua preservação, por manter a integridade de seu conteúdo.

Lembrando que o objetivo primordial do direito contratual, reconhecido desde o tempo de Hobbes, é impedir que os contratantes ajam de maneira oportunista, para encorajar a atividade negocial e evitar gastos com medidas de auto-proteção, Posner também considera que o padrão de boa-fé se resume em não tirar proveito das vulnerabilidades da contraparte, ${ }^{235}$ ou seja, não agir oportunisticamente. As vulnerabilidades aqui referidas concernem tanto à assimetria informacional quanto à

\footnotetext{
${ }^{231}$ MENEZES CORDEIRO, António Manuel da Rocha e. op. cit., p. 1252-1253.

${ }^{232}$ As aplicações concernem aos sistemas do Civil Law. ZIMMERMAN, Reinhard; WHITTAKER, Simon (Eds.). op. cit., p. 676.

${ }^{233}$ MACKAAY, Ejan; ROUSSEAU, Stéphane. op. cit., p. 382.

${ }^{234}$ Id. Ibid., p. 384.

235 "Good-faith performance - which means in this context refraining from taking advantage of the vulnerabilities created by the sequential character of contractual performance - is an implied term in every contract. No one would voluntarily place himself at the mercy of the other party, so it is reasonable to assume that had the parties thought about the possibility of bad faith they would have forbidden it expressly." POSNER, Richard A. Economic analysis of law. $7^{\text {th }}$ ed. New York: Aspen Publishers, 2007. p. 94-95.
} 
disparidade do poder de barganha, e podem afetar qualquer um dos contratantes, dependendo das circunstâncias. E é com este sentido que a boa-fé também serve como critério para a integração e interpretação dos contratos, pois a proibição de explorar as vulnerabilidades da contraparte está implícita nos termos do contrato, já que nenhum contratante se colocaria voluntariamente à mercê do outro, razão pela qual se presume que, se cogitassem de oportunismo, as partes o vedariam. ${ }^{236}$

Outra crítica que se pode traçar à aplicação indevidamente extensiva do princípio da boa-fé no âmbito contratual se baseia na crescente objetivação do contrato. A teoria e a disciplina dos contratos têm revelado "progressiva tendência à redução do papel e da importância da vontade dos contraentes", resumida como objetivação do contrato $^{237}$. Roppo aponta como paradigma dessa transição da concepção subjetiva para a concepção objetiva do contrato, a substituição da teoria da vontade, fundada no dogma da vontade, pela teoria da declaração, baseada no valor da confiança, que propicia uma dimensão de maior certeza nas relações ${ }^{238}$, as quais, em razão do desenvolvimento econômico demandam maior celeridade na contratação, exigindo mais segurança e estabilidade ${ }^{239}$.

Essa tendência de objetivação do contrato recomenda redimensionar a influência que a vontade exerce, não só em relação ao conceito do instituto, como também no tratamento jurídico de cada relação. A mudança não é, pois, apenas conceitual e pontual, mas funcional e sistêmica, porque se reflete no regime jurídico do contrato, e na interpretação dos negócios jurídicos, que devem levar em conta mais a manifestação do que a vontade. $\mathrm{O}$ fundamento subjacente à adoção desse critério de prevalência do aspecto objetivo sobre o subjetivo, ou seja, da declaração sobre a vontade, é a tutela dos interesses do destinatário da declaração, que teria confiado no teor objetivo e perceptível desta, o que redunda na proteção dos interesses de toda a coletividade ${ }^{240}$. Em suma, o fundamento da objetivação do contrato é a tutela da confiança. Conceitualmente, confiança é mais condizente com a objetivação do que a boa-fé, porque retrata reciprocidade e

\footnotetext{
${ }^{236}$ Mackaay e Rousseau ponderam, porém, que nem todas as formas de oportunismo justificam intervenção estatal e sugerem a aplicação do teste proposto por WITTMAN: a economia decorrente da redução do nível de auto-proteção que as partes contratantes escolham, confiando na norma legal que permite sancionar a falta de boa-fé, deve compensar o custo de formulação da regra. MACKAAY, Ejan; ROUSSEAU, Stéphane. op. cit., p. 390.

${ }^{237}$ ROPPO, Enzo. $O$ contrato, cit., p. 297, em que o autor é mais enfático a respeito dessa transição e mais específico em relação aos seus efeitos em relação à disciplina contratual. Mas também é mencionada na edição de Il contratto, cit., p. 38-39.

${ }^{238}$ ROPPO, Vincenzo. Il contratto, cit., p. 38-39.

${ }^{239}$ ROPPO, Enzo. O contrato, cit., p. 298.

${ }^{240}$ Id. Ibid., p. 299.
} 
transitividade, enquanto a boa-fé sugere a unilateralidade própria das intenções, mesmo quando quer significar lealdade contratual, na sua feição objetiva.

O direito brasileiro disciplina o comportamento dos contratantes, exigindo boa-fé e probidade desde a fase pré-contratual, com o objetivo, aqui pressuposto, de elidir o oportunismo, para prestigiar a confiança, assegurar a cooperação e o comprometimento das partes e conferir maior eficiência aos contratos. Tal como na matriz italiana, a norma do art. 422, do Código Civil, estabelece a responsabilidade pré-contratual, embora não trate do dano decorrente da violação do padrão de comportamento ali prescrito, nem das suas consequências. $^{241}$ Mas, a par de instituir um padrão de conduta, a norma legal também opera como cláusula geral, funcionando como parâmetro de interpretação e integração dos contratos.

Tem, portanto, dupla finalidade o instituto da boa-fé inscrito no art. 422 do Código Civil. A boa-fé aí referida é a objetiva, traduzida por correção, como diz Roppo, que a explica como o dever "di evitare durante la trattativa comportamenti che implichino intenzione o consapevolezza d'infliggere a contraparte danni ingiusti”,242. O autor descreve a boa fé objetiva, usando dados subjetivos, como a intenção e a consciência do agente, o que se explica, porque intenção, consciência e fé (boa ou má, objetiva ou subjetiva) são ideias associadas à psique, e, por isso, indissociáveis da subjetividade. Esta íntima conexão entre aspectos objetivos e subjetivos revela que a boa fé nunca será tão objetiva assim, a despeito do esforço da doutrina em retratá-la como tal. A falta de objetividade da boa fé induz a investigação da intenção, o que leva a confundi-la com a boa-fé subjetiva, contrariando a lógica da violação do padrão por culpa, que não é intencional. Porém, como a boa fé objetiva também inclui a diligência, não se refere apenas aos comportamentos intencionais, mas também aos culposos, decorrentes de negligência (disattenzione), imperícia (incompetenza), imprudência ou leviandade (superficialità), como observa Roppo. ${ }^{243}$

Rodolfo Sacco também sustenta que a violação dos deveres compreendidos pela boa-fé, inclusive o de informar, acarreta a responsabilidade por simples culpa. ${ }^{244}$ Essa

\footnotetext{
${ }^{241}$ Invoca-se aqui o direito italiano, devido à similitude dos dois regimes jurídicos. ROPPO, Vincenzo. Il contratto, cit., p. 175.

${ }^{242}$ Grifos nossos. Id. Ibid., p. 176.

${ }^{243} \mathrm{O}$ autor explica que "la violazione della buona fede (oggettiva) non è esclusa dallo stato di buona fede (soggettiva) in cui versi l’ agente.” Id. Ibid., p. 176.

${ }^{244}$ SACCO, Rodolfo. La buona fede nella fase precontratualle. In: SACCO, Rodolfo; DE NOVA, Giorgio. op. cit., v. 2, p. 247-248.
} 
abrangência de condutas culposas pelo conceito da boa fé objetiva é mais uma demonstração de que a intenção do agente não deveria ser relevante para a caracterização de violação da boa-fé objetiva. Mas a dificuldade de aplicar o princípio da boa-fé, mesmo na sua acepção objetiva, sem considerar a intenção do contratante, acaba tornando inoperante o dever de informar.

Como padrão de conduta ou como cláusula geral, o alcance da boa-fé realmente permite abranger comportamentos que não se enquadrariam em nenhum outro instituto jurídico, o que lhe asseguraria relevante função balizadora da interação humana. Mas sua extensão e elasticidade semântica a transformam num recipiente vago a ser preenchido de acordo com os valores morais, sociais, culturais e ideológicos do intérprete, abrindo vastíssimas possibilidades de interpretação. Por isso, a utilidade da abrangência do princípio é ofuscada pela incerteza que propicia.

Dada a elasticidade exagerada do princípio da boa-fé, é comum combiná-lo com as regras nele compreendidas. A combinação de um padrão, ou de um princípio, com regras de conduta poderia ser eficiente, porque a objetividade e a incisividade destas complementam e compensam o efeito mais abrangente e genérico daquele ${ }^{245}$. Comparando regras e padrões, Cohen aponta as vantagens e desvantagens daquelas em contraposição a estes. Regras evitam que os tribunais usem discricionariedade e aceleram o processo judicial. Mas sua aplicação ao caso concreto poderá ser inadequada. Padrões servem para corrigir a eventual inadequação decorrente da inflexibilidade das regras, mas podem acarretar incerteza jurídica. Discricionariedade tem o potencial de permitir abuso, ou certa desigualdade na aplicação dos padrões, decorrente da dificuldade de descobrir e determinar precedentes devido à aplicação de normas fluidas aos casos concretos. Seu uso aumenta a zona cinzenta e pode incentivar a desobediência, pois, assim como a regra cria expectativas em relação à sua aplicação, também o desvio dela provoca estímulo contrário. ${ }^{246}$

\footnotetext{
${ }^{245}$ Ao tratar de estratégias regulatórias, Hansmann e Kraakman apontam a distinção entre standards e rules e sua aplicação. Embora o texto se refira especificamente aos problemas de agência no direito societário, tem relação com o tema aqui examinado, porque tais conflitos também implicam oportunismo dos agentes. Além disso, o enfoque de regras e padrões é genérico, aplicando-se também à distinção entre princípios e regras e entre estas e a cláusula geral. HANSMANN, Henry; KRAAKMAN, Reinier. The anatomy of corporate law, a comparative and functional approach. Oxford: Oxford University Press, 2004. p. 23-24.

${ }^{246}$ Relata Cohen que a experiência do direito israelense demonstra que a adoção do padrão de comportamento moral impõe preço alto que se dispõe a pagar quem pretende elevar o padrão da conduta moral no domínio contratual. Mas esta observação traz ínsita uma contradição, pois, se a adoção legal do padrão alarga a zona cinzenta de sua aplicação e incita o descumprimento da lei, além de aumentar a imprevisibilidade das decisões judiciais e a insegurança jurídica, não nos parece que isso contribua para elevar o nível moral, por assim dizer, das relações contratuais. Não se pretende com essa crítica, extirpar todos os princípios positivados na lei, mas, em se constatando tais restrições à sua adoção para aplicação direta, não se
} 
Em conhecido $\operatorname{artigo~}^{247}$ no qual discute diferenças entre regras e padrões, Kaplow pondera que regras sempre tendem a ser mais eficientes do que os padrões. Primeiro, porque acarretam menos custos do que estes para orientar os agentes sobre condutas passíveis de sanção, e para guiar intérpretes na aplicação da norma, cujo conteúdo não precisa ser preenchido ex post. Segundo, porque, quando indivíduos podem prever antecipadamente como certa regra será aplicada, tenderão a pautar sua conduta estritamente por ela, pois é mais fácil observar uma norma de conteúdo determinado ex ante, do que obedecer a padrões cujo conteúdo será determinado ex post, em juízo. ${ }^{248}$

Em suma, princípios e modelos muito abertos de padrão de conduta ou de cláusula geral desnorteiam o intérprete em vez de orientá-lo. A ambiguidade do modelo prejudica sua aplicação, pois a boa-fé remete à ideia do elemento subjetivo nela implícita, induzindo a perquirir a intenção do agente, ainda quando esta for irrelevante. Daí a conveniência de reduzi-la à sua função residual e instituir o dever de informar, como disciplina contratual autônoma.

vislumbra razão alguma de ordem lógica, filosófica ou jurídica, para que não se combinem princípios e regras. Daí a conveniência e a necessidade de se destacarem do padrão de boa-fé os deveres objetivos que dele emanam, formulando seus respectivos modelos, para aplicá-los diretamente. COHEN, Nili. Precontractual duties: two freedoms and the contract to negotiate. In: BEATSON, Jack; FRIEDMANN, Daniel (Eds.). Good faith and fault in contract law. 1995, rep. 2002. Oxford: Claredon Press, 2002. p. 53.

${ }^{247}$ KAPLOW, Louis. Rules versus standards: an economic analysis. Duke Law Journal, v. 42, n. 3, p. 557629, Dec. 1992.

${ }^{248}$ Observa o autor que o principal fator que afeta a adequabilidade de regras ou de padrões é a frequência com que a lei regerá a conduta. Se frequente, os custos adicionais de formular a regra, em que só se incorre uma vez, tenderão a ser excedidos pelas economias obtidas na aplicação das regras. KAPLOW, Louis. op. cit., p. 621. E conclui: "Thus, rules involve a wholesale approach to an information problem, that of determining the laws appropriate content. Standards instead require adjudicators to undertake this effort, which may have to be done repeatedly (unless the standard is transformed into a rule through precedent). And, regardless of whether adjudication will be frequent, many individuals contemplating behavior that may be subject to the law will find it more costly to comply with standards, because it generally is more difficult to predict the outcome of a future inquiry (by the adjudicator, into the law's content) than to examine the result of a past inquiry. They must either spend more to be guided properly or act without as much guidance as under rules. Thus, when behavior subject to the relevant law is frequent, standards tend to be more costly and result in behavior that conforms less well to underlying norms. Some implications of this analysis run contrary to prevailing wisdom or suggest problems with common practices. Thus, it is usually said that standards result in more precise application of underlying norms because they can be applied to the particular facts of a case, in contrast to rules, which apply to the generality of cases. But if the cases are anticipated to arise frequently and have important recurring characteristics, rules will not only be preferable, but might be expected to be more precise.19' In such instances, it is worth investing substantial effort to fine-tune a rule system. But, with standards, it may not be worth spending much effort to get precise results, because such efforts will be useful in resolving only a single case rather than many. Moreover, even in instances where standards would produce more accurate results in adjudication, rules may nevertheless produce behavior more in accord with underlying norms. The reason is simply that the rules, announced in advance, are more likely to influence actual behavior, whereas individuals may find it infeasible or too costly to predict how an adjudicator will apply a standard to their behavior." KAPLOW, Louis. op. cit., p. 621-622. 


\section{Boa-fé e teoria da aparência}

A teoria da aparência é uma das expressões da proteção jurídica da confiança, subjacente tanto à boa-fé subjetiva como à objetiva. A tutela da confiança ou a proteção da aparência de direito nas suas variadas formas prestigia a circulação de riquezas e o dinamismo econômico. ${ }^{249}$

Cabe a qualquer ordem jurídica a missão indeclinável de garantir a confiança dos sujeitos, que constitui pressuposto fundamental da interação humana e da cooperação jurídica $^{250}$. A confiança é um instrumento de redução da complexidade social, na sintética e precisa definição de Luhmann, ${ }^{251}$ que parte da função para o conceito. O sistema jurídico também deve funcionar como redutor da complexidade social, ${ }^{252}$ no sentido de que deve

${ }^{249}$ MENEZES CORDEIRO, António Manuel da Rocha e. op. cit., p. 1247. O autor afirma que a confiança é o substrato material da boa-fé: “A aproximação entre confiança e boa fé constitui um passo da Ciência Jurídica que não mais se pode perder. Mas ele só se torna produtivo quando à confiança, se empreste um alcance material que ela, por seu turno, comunique à boa fé”. Id. Ibid., p. 1241.

${ }^{250}$ FRADA, Manuel António de C. P. Carneiro da. Teoria da confiança e responsabilidade civil. Reimpr. da ed. de 2004. Coimbra: Almedina, 2007. p. 19.

${ }^{251}$ LUHMANN, Niklas. Vertrauen - Ein Mechanismus der Reduktion sozialer Komplexität, Sttutgart: Lucius und Lucius, 2000. p. 42-43.

${ }^{252}$ Luhmann traça uma comparação entre a função da confiança e a do Direito, aduzindo que, nos sistemas sociais simples e pequenos, com poucos problemas estruturais, e em que todos são conhecidos entre si, a quebra da confiança é uma afronta às regras da vida conjunta (normas sociais) e, concomitantemente, ao direito vigente. Portanto, nesses casos, a confiança exerce função sancionadora dos comportamentos e mantenedora da ordem social, coincidente com o papel do Direito. Ressalva que, somente nestas hipóteses (de sistemas sociais simples) pode haver congruência, ou uma sobreposição, entre Direito e confiança. Mas nos sistemas sociais complexos, em que as relações são impessoais e os riscos são maiores, e a confiança não está sob controle social, e a expectativa de confiança é mais difusa, é necessário instituir mecanismos para redução da complexidade, especificá-los melhor e aplicá-los mais eficientemente. Neste caso, o Direito supre o papel que a confiança desempenharia nos grupos sociais pequenos. Daí se entrevê a afinidade de funções exercidas pelo Direito e pela confiança, o que induz a conclusão de que, para exercer o papel balizador e sancionador nos grandes grupos sociais, a previsibilidade das regras e de sua aplicação deve ser tão perfeita quanto possível para permitir que o Direito cumpra eficientemente o papel que a confiança desempenha nos pequenos grupos. E também se entrevê certa correspondência entre as constatações de Luhmann e as de North, em relação ao papel das instituições formais e informais, embora eles focalizem a realidade de perspectivas diferentes. Id. Ibid., p. 41-42. FRADA, embora não faça referência a Luhmann nessa passagem, endossa a concepção do sociólogo em relação ao papel da confiança e do Direito: “(...) sobretudo na sociedade altamente diferenciada e complexa como a atual, impõe-se, afinal, uma discriminação entre o Direito e a confiança: o primeiro intervém para assegurar níveis de interação social precisamente aí onde o processo de coordenação interindividual das condutas humanas através da confiança se torna, por dificuldade ou ineficiência, impraticável. (...) quanto maior for, por via da referida complexidade e diferenciação, a despersonalização e o anonimato na vida social, mais aguda se torna a acuidade da substituição do processo informal de coordenação dos comportamentos através da confiança pela institucionalização de regras jurídicas formais. FRADA, Manuel António de C. P. Carneiro da. op. cit., p. 18. Menezes Cordeiro assevera que a importância sociológica assumida pela confiança não deve levar, no seu alcance, como na sua construção, a uma transposição mecânica para o Direito. Argumenta que as reduções permitidas pela confiança num contrato celebrado não advêm tanto das expectativas de comportamento regular da outra parte, como da confiança inculcada pela inserção do pacto em canais jurídicos, cujo percurso se encontra pré-determinado. MENEZES CORDEIRO, António Manuel da Rocha e. op. cit., p. 1242. Se a confiança advém da pré-determinação das normas jurídicas, que conferem 
assegurar a confiança na interação dos agentes, permitindo maior previsibilidade de resultados, e, com isso, a simplificação do processo decisório, e a redução dos custos de transação. Estas correspondem a algumas das principais funções das instituições no domínio dos contratos. E quanto mais impessoais forem os contratos, e diferida no tempo sua execução, quanto mais complexa a organização social, mais importante será o papel da confiança e a função do Direito de promovê-la e preservá-la. ${ }^{253}$

Confiança é, pois, um elemento essencial nas relações jurídicas, especialmente no contrato, e, como lembra Jaluzot, remete ao princípio consubstanciado no brocardo Treu und Glauben, que empresta à boa-fé uma conotação de fidelidade e confiança. ${ }^{254} \mathrm{O}$ princípio da confiança, elemento basilar da boa-fé e que também informa o direito contratual, não se pauta pela subjetividade da intenção do agente, mas pela transitividade e reciprocidade inerentes à confiança, justificando a sanção do comportamento que a desmerece, independentemente da intenção do agente ${ }^{255}$.

A teoria da aparência atribui validade e eficácia a negócios jurídicos inexistentes ou inválidos, com o objetivo de proteger o contratante que ignora os vícios que os inquinavam, apesar de ter agido de boa-fé e com ordinária diligência. Porém, ao equiparar situação de aparência a uma situação jurídica legítima, o direito trata de problemas de informação nos contratos, não só com o intuito de proteger a parte desinformada, mas de evitar gastos com auto-proteção, pois assegurar a confiança reduz custos de transação e garante a segurança jurídica. Sendo justificável a desinformação da parte enganada, ou, seja, revelando-se muito custosa ou difícil a obtenção da informação, a lei reverte os riscos derivados da assimetria informacional à parte que a propiciou. A análise econômica da

previsibilidade às relações entre os agentes, a indeterminação inerente à boa fé se opõe a esta ideia, o que implica que a boa fé não pode ser eficiente nem como baliza de comportamentos nem como instrumento de orientação jurisprudencial. MENEZES CORDEIRO, António Manuel da Rocha e. op. cit., p. 1242.

${ }^{253}$ Luhmann aponta a relação entre confiança e tempo ("Wer Vertrauen erweist, nimmt Zukunft vorweg."), mostrando que a confiança permite antecipar o tempo (tradução livre). Num expressivo jogo de palavras, o autor explica o papel da confiança, apontando a distinção entre "gegenwärtiger Zukunft und künftigen Gegenwaten", indicando que a confiança é que faz a diferença entre trazer o futuro para o presente ou empurrar o presente para o futuro. LUHMANN, Niklas. op. cit., p. 14. É justamente por isso que a imprevisibilidade e a insegurança jurídicas, ao gerarem desconfiança, representam o atraso dos países que não sabem cultivá-la por meio das normas sociais ou formais, e que nos remete à lição de Akerlof, cujo trabalho abordou o problema da falta de confiança nas relações comerciais e apontou seus efeitos perversos.

${ }^{254}$ JALUZOT, Béatrice. op. cit., p. 86.

${ }^{255} \mathrm{O}$ conceito de confiança também se afigura indeterminado pela pluralidade de empregos comuns que alberga, dificultando a investigação jurídica de seus limites, e por sua ambiguidade poder referir-se tanto à causa como aos efeitos de uma regulação jurídica. FRADA, Manuel António de C. P. Carneiro da. op. cit., p. 17. Porém, a despeito dessa indeterminação, retrata mais a objetividade do princípio do que a subjetividade da boa-fé. 
proteção da boa-fé se resume, segundo Schäfer e Ott, em avaliar as condições de criação de incentivos para a produção de informações socialmente produtivas ao menor custo. ${ }^{256}$

Conforme a regra de que cabe ao contratante informar-se a respeito dos elementos do negócio jurídico, em princípio, cada um arca com o ônus de obtenção das informações que lhe interessam, e, consequentemente, com os riscos da própria desinformação. Por isso, nem toda assimetria informacional deve ensejar proteção do agente desinformado. ${ }^{257}$ Nos contratos onerosos, o direito prestigiará a situação de aparência, se esta for objetivamente apta a ludibriar a boa-fé do iludido, desde que ele não tenha agido com culpa, e a dificuldade ou o custo de aquisição da informação justificar a sua proteção.

São hipóteses da aplicação da teoria a aquisição a non domino (arts. 879, CC e 1201, § único, CC), e a herdeiro aparente (arts. 1817 e 1827, § único, CC), o pagamento a credor aparente (art. 309, CC) e a aparência de representação (arts. 686 e 689, CC).

Distingue-se, segundo Frada, a responsabilidade pela confiança da decorrente da violação de deveres de agir, porque nesta os requisitos são os da culpa in contrahendo, enquanto "os requisitos da proteção legal da confiança são a razoabilidade da convicção do confiante e o investimento de confiança". 258

\section{Boa-fé e Dever de Informar}

A informação ainda não recebeu tratamento jurídico adequado, apesar da importância do papel por ela exercido, especialmente no direito contratual, que, no entanto, não lhe confere autonomia, mas a trata como desdobramento da boa-fé, ou como fator subjacente aos vícios de consentimento e ao redibitório. Embora o dever de informar possa ser considerado corolário desse princípio, não deveria ser reduzido a isso, em razão das idiossincrasias inerentes à interpretação da boa-fé, já discutidas nos tópicos anteriores, e da melhor aplicação do dever como regra autônoma.

\footnotetext{
${ }^{256}$ SCHÄFER, Hans-Bernd; OTT, Claus. op. cit., p. 375. Asseveram os autores que, se a confiança economiza custos de informação, então sua proteção legal implica que uma das partes contratantes é dispensada desses custos enquanto a outra é onerada por eles. Esta regra impõe a uma parte o ônus de informar, para não ser responsabilizada por má-fé (quebra de confiança), se o custo do fornecimento da informação for menor que o custo de sua eventual responsabilidade. Por isso, a proteção legal à boa-fé facilita as relações jurídicas. Id. Ibid., p. 381-382.

${ }^{257}$ Já observamos, em capítulo anterior, que nem todo problema de assimetria informacional comporta regulação, mas os critérios da Análise Econômica do Direito só serão abordados no capítulo 5.

${ }^{258}$ FRADA, Manuel António de C. P. Carneiro da. op. cit., p. 902-903.
} 
A lei italiana também associa a quebra do dever de informar, caracterizada pela omissão e falsidade de declaração, à violação do princípio da boa-fé, mas a interpretação doutrinária mais estrita contribui para evitar sua elasticidade exagerada. ${ }^{259}$ Como a boa-fé implica lealdade contratual, que pressupõe o dever de informar, a imposição desse dever legal se aplicaria, segundo Roppo, aos casos em que "a parte que conhece (ou deveria conhecer) dados relevantes para a valoração do contrato do ponto de vista da contraparte, e sabe (ou deveria saber) que esta os desconhece". ${ }^{260}$ Como se depreende das expressões aqui destacadas, a parte a quem é atribuído o ônus da informação no contrato, não se desincumbe do dever legal, com a mera alegação de ignorância. Somente o desconhecimento justificável e, portanto, não culposo, da informação a ser transmitida e da desinformação da contraparte é apto a desonerar o contratante a quem o dever incumbe. À parte desinformada cabe demonstrar que a contraparte conhecia ou deveria conhecer a informação. E ao contratante supostamente informado incumbiria demonstrar que, mesmo tendo agido com prudência e diligência, não a conhecia, ou não achou que devia transmitila ao outro contratante. Isso equivale à presunção de culpa, porque incumbe ao culposo afastá-la, demonstrando sua diligência e prudência. De acordo com esta leitura, o dever de informar ensejaria responsabilidade extracontratual por dolo ou culpa, podendo esta ser presumida, o que implica inversão do ônus da prova. A possibilidade de violação da boa-fé por simples culpa é corroborada pela doutrina predominante. ${ }^{261}$ Ademais, como informar pressupõe revelar a verdade, Roppo ressalta que agrava a ocultação se esta resulta de pergunta ou requisição de informação da contraparte. ${ }^{262}$ Portanto, além de a culpa configurar violação do princípio da boa-fé, por quebra do dever de informar, a má-fé constituirá agravante. Esta concepção mais exigente do princípio da boa-fé e dos deveres de informação contribui para assegurar a confiança nas relações entre os agentes, promovendo o desenvolvimento da atividade econômica.

No Brasil, intérpretes desavisados tendem a considerar que a boa-fé só é afastada pela má-fé, como sugere a antonímia. Isso parece lógico e coerente, mas só se poderia aplicar à boa-fé subjetiva, porque, em se tratando da chamada boa-fé objetiva, que abrange,

\footnotetext{
${ }^{259}$ Invoca-se aqui o modelo italiano, que serviu de inspiração para o nosso Código Civil, para efeito de comparação dos enfoques doutrinários dos dois países.

${ }^{260}$ ROPPO, Vincenzo. Il contratto, cit., p. 177.

${ }^{261}$ SACCO, Rodolfo. La buona fede nella fase precontratualle, cit., v. 2, p. 247-248; ROPPO, Vincenzo. Il contratto, cit., p. 176; MACKAAY, Ejan; ROUSSEAU, Stéphane. op. cit., p. 384-385; SUMMERS, Robert. Good faith in general contract law and the sales provisions of the Uniform Commercial Code. Virginia Law Review, n. 54, p. 216, Mar. 1968.

${ }^{262}$ SACCO, Rodolfo; DE NOVA, Giorgio. op. cit., v. 1, p. 178.
} 
além da boa intenção, a diligência e a prudência, não faz sentido considerar que apenas a má-fé a exclui, porque, para ser coerente com essa abrangência, a negligência e a imprudência também a excluiriam. Mas daí resulta que se pode violar a boa-fé sem ter agido de má-fé. Esse aparente contrassenso contribui para gerar interpretações equivocadas. E é aparente porque, neste caso, a antonímia entre boa-fé e má-fé não existe, pois sendo uma objetiva e a outra subjetiva, são falsos opostos. Significa que se pode violar a boa-fé objetiva sem ter agido de má-fé subjetiva. Embora pareça contraditório, não é, porque mesmo não agindo de má-fé é possível afrontar a boa-fé objetiva, quando a quebra do dever de informar, contido na cláusula geral de lealdade contratual, for decorrente de conduta culposa.

A impropriedade exegética se deve, em parte, à confusão semântica derivada da justaposição do adjetivo objetiva para qualificar o substantivo boa-fé, a despeito da congênita incompatibilidade entre os dois termos. A atecnia dessa justaposição terminológica torna equívoca a relação entre significado e significante, como se já não bastassem a amplitude e elasticidade do termo boa-fé. São filigranas linguísticas, mas, como a palavra é a ferramenta do Direito, podem dar margem a interpretações disparatadas, porque adstritas à literalidade da contraposição entre boa e má fé, além das dificuldades criadas pela plurivocidade do princípio da boa-fé. Se, em quaisquer circunstâncias não se deve restringir o exercício exegético à interpretação literal, com mais razão neste caso em que a impropriedade terminológica pode induzir traduções disparatadas do espírito da lei.

Considerando a equivocidade do instituto da boa-fé e as divergências exegéticas que suscita, quanto mais se reduzir sua aplicação, tanto mais técnico e objetivo será o resultado obtido em relação aos deveres nele compreendidos.

A boa-fé se cristaliza num leque de instituições mais específicas, adequadas aos seus respectivos regimes ${ }^{263}$. Decompõe-se em uma série de deveres, como lealdade, correção, cooperação, diligência, transparência e veracidade, e estes dois últimos se resumem no dever de informar, embora os demais também estejam, em certa medida, aí contidos. Mas esta decomposição do princípio da boa-fé em institutos específicos não será apta a conferir objetividade à apreciação de cada um deles no caso concreto, se for preservada, na aplicação desses institutos, a relação de acessoriedade e dependência traçada pela doutrina entre eles e o princípio matriz.

${ }^{263}$ MACKAAY, Ejan; ROUSSEAU, Stéphane. op. cit., p. 382. 
A disciplina do dever de informar produziria resultado mais eficiente se fosse delineado como instituto correlato à boa-fé, mas não como mero acessório desta. Isto já foi aplicado à legislação especial, como no direito societário e mercado de capitais, em que o dever de informar é tratado de forma objetiva, não se cogitando da intenção do agente para a caracterização de sua violação.

A tendência de objetivação do contrato, reconhecida pela doutrina desde a crise do dogma da vontade, alcança a disciplina da boa fé: no âmbito dos contratos, a boa-fé está para a teoria da vontade, assim como o dever de informar está para a teoria da declaração. Não há, portanto, razão lógica ou jurídica para que não se adote o dever de informar como instituto autônomo, independente da boa-fé, permitindo uma abordagem muito mais objetiva do regime da informação nos contratos.

O fundamento filosófico do dever de informar se coaduna melhor com a confiança no sentido conferido à boa-fé pelo direito alemão, que a traduz como Treu und Glauben, significando confiabilidade e confiança, ou, em outras palavras, confiar no que é confiável. $^{264}$ Esse binômio confiança-confiabilidade não carrega as incongruências intrínsecas da boa-fé, é mais objetivo, porque despojado de fatores psicoemotivos.

Confiança pressupõe informação. Mackaay e Rousseau afirmam que a confiança nada tem de irracional, pois é a utilização racional da informação. ${ }^{265}$ É atributo essencial e indispensável às trocas econômicas. Incentivar a confiança e a confiabilidade das condutas dos contratantes é um dos objetivos a serem cumpridos pelo direito contratual, pois quanto maior a confiança, maior o volume de negócios, mais ganhos recíprocos, o que tende a propiciar mais bem-estar social.

A desconfiança recíproca tem o efeito claramente perverso de reduzir os negócios aos contratos de execução instantânea, que dependem menos da confiabilidade dos agentes, circunscrevendo as relações a um estreito círculo de conhecidos, e, consequentemente, encolhendo o mercado. ${ }^{266}$

Como a confiança tem por pressuposto a informação e a confiabilidade dos dados informados, o que traduz transparência e veracidade, incentivá-la implica facilitar a

\footnotetext{
${ }^{264}$ Treu und Glauben significa literalmente fidelidade e crença, mas a tradução livre proposta no texto traduz melhor, a nosso ver, o sentido de transitividade e reciprocidade contido na expressão.

${ }^{265}$ MACKAAY, Ejan; ROUSSEAU, Stéphane. op. cit., p. 385.

${ }^{266}$ COOTER Robert; SCHÄFER, Hans-Bernd. Desconfiança recíproca. Trad. Luciano B. Timm. In: SALAMA, Bruno Meyerhof (Org.). Direito e economia: textos escolhidos. Salama. São Paulo: Saraiva, 2010. p. 305-323.
} 
obtenção de informação e prestigiar o dever de prestá-la, impondo-o ao contratante que tiver melhores condições de arcar com ela ao menor custo, o que contribuirá para a redução dos gastos com auto-proteção.

A informação disponível aos contratantes estabelece o nível de confiança das partes em relação ao contrato entabulado e é um dos fatores determinantes de sua conclusão. Mas imperfeições informacionais somente serão danosas, se propiciarem condutas oportunistas, ex ante ou ex post, permitindo a indevida apropriação pelo agente mais informado da parte da renda gerada pelo contrato, à qual faria jus a contraparte. Portanto, somente se um contratante puder auferir vantagem indevida da assimetria informacional desfavorável à contraparte, apropriando-se de ganhos que, em situação paritária, seriam divididos entre as partes, será o caso de impor o dever de informar. ${ }^{267}$

Também não se pode olvidar que as relações diferidas no tempo implicam incertezas e riscos que representam obstáculos à cooperação, que será tanto mais incentivada quanto mais o sistema jurídico estimular o cumprimento dos contratos. Por isso, as causas de anulação, redibição, revisão, rescisão ou resolução do contrato devem ser bem delineadas e interpretadas restritivamente, em razão de seu caráter excepcional, para preservar o comprometimento das partes em relação à regular execução das obrigações pactuadas.

A natureza do dever de informar é extracontratual, pois a contratual não se coaduna com a fase das negociações preliminares à contratação. ${ }^{268}$ Como reconhece Junqueira de Azevedo, a responsabilidade contratual não é adequada às tratativas prévias, mas daria direito à reparação independente de culpa, porque se fundamenta na fides (princípio da palavra dada), enquanto a aquiliana tem o inconveniente de exigir prova da culpa, o que é difícil. $^{269}$ É certo que a responsabilidade contratual se lastreia no próprio vínculo estabelecido entre as partes, ${ }^{270}$ admitindo, pois, a responsabilidade objetiva, que dispensa culpa. Mas a responsabilidade extracontratual, no âmbito do dever de informar, não nos

\footnotetext{
${ }^{267}$ Trataremos dos critérios propostos pela Análise Econômica para o dever de informar no capítulo 5.

${ }^{268}$ No Brasil, é a opinião doutrinária predominante. Na doutrina italiana, mais uma vez invocada em razão da afinidade com o nosso regime jurídico contratual: BIANCA, C. Massimo. op. cit., p. 157-159, GALGANO, Francesco. Obbligazioni in generalli. Padova: CEDAM, 2007. p. 552; ROPPO, Vincenzo. Il contratto, cit., p. 184; SACCO, Rodolfo. Natura e misura della responsabilità. In SACCO, Rodolfo e DE NOVA, Giorgio. op. cit., t. 2, p. 260-261.

${ }^{269}$ JUNQUEIRA DE AZEVEDO, Antonio. A boa-fé na formação dos contratos. In: NERY JR., Nelson; NERY, Rosa Maria de Andrade (Orgs.). Doutrinas essenciais: responsabilidade civil: direito das obrigações e direito negocial. 2. tir. São Paulo: Ed. Revista dos Tribunais, 2010. v. 2, p. 415-423.

${ }^{270}$ Porque a autonomia privada implica submissão voluntária às regras estabelecidas pelas partes, e consequentemente a auto-responsabilização.
} 
parece exigir prova da culpa do contratante mais informado, porque, uma vez imposto um dever legal, incumbe ao agente, ao qual foi atribuído, o ônus de provar que não o descumpriu ou que não seria o caso de cumpri-lo. ${ }^{271}$ Parece-nos que é esse o estreito âmbito probatório em relação aos deveres legais. ${ }^{272}$ É o que ocorre, por exemplo, em relação ao dever de informação no domínio das sociedades anônimas.

Em resumo, o que se propõe aqui, em relação ao regime jurídico da informação, é a instituição de regras próprias e autônomas que disciplinem de forma objetiva o dever de informar nos contratos, reservando à boa-fé a aplicação residual aos casos não alcançados pelo dever legal.

\footnotetext{
${ }^{271}$ Isso se equipara à presunção de culpa, que comporta prova em contrário, mas onera o suposto culpado.

${ }^{272} \mathrm{E}$ a razão disso é análoga à da autonomia privada, porque fundamento remoto aqui é o contrato social, que implica a submissão voluntária às regras estabelecidas na sociedade.
} 


\section{CAPÍTULO 4. BOA-FÉ E DEVER DE INFORMAR NO DIREITO COMPARADO}

A abordagem conjunta dos dois institutos se deve à correlação que doutrina e jurisprudência estabelecem entre eles, justificada pelo estreito nexo existente entre informação e boa-fé, e ao fato de que, embora de forma complementar e de perspectivas diferentes, ambos se destinam à proteção da confiança recíproca no âmbito contratual. A boa-fé objetiva representa padrão genérico de conduta para os contratantes, e, concomitantemente, cláusula geral que orienta a interpretação dos contratos de acordo com aquele comportamento previsto. ${ }^{273}$ De outro lado, o dever de informar, considerado corolário do princípio da boa-fé, estabelece regra de conduta, permitindo a identificação imediata e objetiva da inobservância da lei, e fornecendo parâmetros para a avaliação antecipada de seu conteúdo pelos agentes. ${ }^{274}$

Como os contratos de execução diferida são sempre incompletos, dada a impossibilidade de previsão de todas as contingências intrínsecas ou extrínsecas que podem afetar seu cumprimento, a cláusula geral de boa-fé é usada na sua interpretação e integração. À luz da teoria da declaração, em geral, interessa mais a perspectiva do destinatário do que a do declarante, mas sua confiança só merece proteção na medida de sua boa-fé e diligência. Portanto, a boa-fé opera em dupla direção. ${ }^{275}$

\footnotetext{
${ }^{273}$ Zimmerman e Whittaker sustentam que a adoção da boa-fé como padrão de conduta contratual e critério de interpretação deve decorrer de um raciocínio de duas etapas: só depois de se constatar que não há outros meios legais aptos a substituí-la adequadamente, e, só então, verifica-se que motivos haveria para que se aplique a cláusula de boa-fé, deixando entrever que, assim como Mackaay e Rousseau, também a classificam como categoria residual. ZIMMERMAN, Reinhard; WHITTAKER, Simon (Eds.). op. cit., p. 135.

${ }^{274}$ SEFTON-GREEN aponta três fontes do dever de informar: a teoria dos vícios de consentimento (erro e dolo), embora seja mais amplo que estes; a interpretação jurisprudencial da cláusula geral de boa-fé; e a legislação especial dirigida a determinadas categorias de agentes econômicos. SEFTON-GREEN, Ruth (Ed.). Mistake, fraud and duties to inform in European contract law. Cambridge: Cambridge University Press, 2005. p. 387.

${ }^{275}$ (...) Therefore, it is consequent to take the addressee's perspective as the relevant point of view because the contract is an act of communication with this party only and it concerns only his or her interests. To define this perspective more precisely, one has to assume that the addressee seeks to grasp the understanding of the declaring party in a reasonable way and in good faith. Under the postulate of individual responsibility, on the one hand, it is not expecting too much of the declaring party to be bound by a reasonable and fair understanding and, on the other hand, only reliance in such an understanding deserves protection by the law. Therefore, this view has two sides. The declaring party as well as the addressee is held to an understanding which the latter party was able to have and ought to have had when a standard of reasonableness and good faith is applied. The test works equally for and against both parties: As little as the declaring party can allege his understanding if it is unreasonable or contrary to the requirements of good faith, he cannot be held to an unreasonable or unfaithful understanding the addressee might have had. CANARIS, Claus-Wilhelm; GRIGOLEIT, Hans Christoph. Interpretation of contracts. p. 4. Social Science Research Network. Disponível em: <http://ssrn.com/abstract=1537169>.
} 
Segundo Canaris, a teoria objetiva do contrato não prescinde da boa-fé e da culpa in contrahendo, porque normas objetivas carecem da elasticidade necessária para alcançar certos comportamentos que não se enquadrem perfeitamente na tipicidade inflexível da regra. Kessler e Fine comentam que, se por um lado, a certeza jurídica é ilusória e eventualmente só pode ser mantida a um custo elevado, e as noções flexíveis de justiça podem afastar a necessidade de contornar a inflexível aplicação de regras mecânicas, por outro lado, é arriscado aplicar indiscriminada e entusiasticamente o princípio da boa-fé. Ponderam, então, os autores que a boa-fé e a culpa in contrahendo usadas com parcimônia, são categorias residuais cuja existência é vital para abrir o sistema jurídico, restringindo a liberdade contratual, no interesse de sua própria preservação. ${ }^{276} \mathrm{E}$, em prol da certeza jurídica, o direito confronta a tarefa de identificar e categorizar esses amorfos conceitos residuais, num processo infindável. ${ }^{277}$

Restringimos a análise do direito comparado aos mais representativos exemplos do sistema de Common e de Civil Law: de um lado, Inglaterra e Estados Unidos, e de outro, Alemanha, França, Itália, observando que outros, como Irlanda, Escócia, e Portugal, Espanha, Holanda e Suíça, acompanham o seu respectivo bloco, com pequenas variações, não alterando o resultado final da comparação. Além disso, abordamos os aspectos pertinentes da uniformização normativa europeia.

\section{Direito Alemão}

Na Alemanha, o princípio da boa-fé se traduziu no conceito Treu und Glauben (fidelidade e fé), expressão que, segundo Zimmerman e Whittaker é encontrada em diversas fontes medievais, e foi utilizada, no contexto das relações comerciais, como sinônimo de bona fides. Adotada pelo BGB (Bürgerliches Gesetzbuch), sua aplicação gerou muita controvérsia nas primeiras décadas do século XX. ${ }^{278}$ Considerada por uns a 'rainha das regras', e vista por outros como 'fonte da peste funesta', capaz de destruir a

\footnotetext{
${ }^{276}$ Como os outros autores comparatistas referidos neste tópico, estes também consideram a boa-fé uma categoria residual e amorfa, que exige constante trabalho de identificação e classificação, e cuja utilização deve ser muito criteriosa. KESSLER, Friedrich; FINE, Edith. Culpa in contrahendo, bargaining in good faith, and freedom of contract: a comparative study. Faculty Scholarship Serie. Paper 2724, p. 448-449. Disponível em: <http://digitalcommons.law.yale.edu/fss_papers/2724>.

${ }^{277}$ Id. Ibid., p. 449.

${ }^{278}$ ZIMMERMAN, Reinhard; WHITTAKER, Simon (Eds.). op. cit., p. 19.
} 
essência da cultura legal germânica, a adoção do princípio despertou reações contraditórias. $^{279}$

No direito alemão, é mais fácil dissociar os conceitos de boa-fé objetiva (Treu und Glauben) e subjetiva (guter Glaube), não só por serem expressas em termos distintos, mas também pelo sentido de transitividade e reciprocidade, que traduz melhor a objetividade da primeira. Guter glaube retrata o desconhecimento do agente, a despeito de ter agido com ordinária diligência, como o caso do adquirente de boa-fé na aquisição a non domino. Treu und Glauben é um padrão legal que serve de baliza à atuação dos contratantes, e funciona como critério de apreciação de sua conduta antes da celebração do contrato e durante sua execução. Como tal, é norma aberta, cujo conteúdo se amolda a cada caso concreto, o que explicaria a necessidade de desenvolvimento teórico e prático de um guia para a aplicação do princípio, como, segundo Zimmerman e Whittaker, teria sido feito pela jurisprudência alemã. ${ }^{280}$

Segundo Ebke e Steinhauer a doutrina da boa-fé cumpre três funções básicas no direito contratual alemão: serve como base legal para a elaboração intersticial da lei pelo Judiciário, compõe fundamento jurídico das defesas em juízo, e provê embasamento legal para a realocação de riscos nos contratos. ${ }^{281}$

A origem remota da responsabilidade pré-contratual, segundo SCHERMAIER, está na noção de dolus in contrahendo, que estendeu o padrão de boa-fé às negociações preliminares ao contrato. ${ }^{282}$ Mas foi Jhering que sistematizou estes rudimentos na teoria da culpa in contrahendo. Embora inspirado no Código Civil francês de 1804, o princípio da boa-fé encontrou melhores condições para se desenvolver no direito alemão, pois a doutrina de Jhering ${ }^{283}$ já focalizara a responsabilidade pré-contratual da parte que age culposamente durante as negociações preliminares à conclusão do contrato. Segundo a

\footnotetext{
${ }^{279}$ ZIMMERMAN, Reinhard; WHITTAKER, Simon (Eds.). op. cit., p. 20.

${ }^{280}$ Id. Ibid., p. 30.

${ }^{281}$ EBKE, Werner F.; STEINHAUER, Betina M. The doctrine of good faith in german contract law. In: BEATSON, Jack; FRIEDMANN, Daniel (Eds.). Good faith and fault in contract law. 1995, rep. 2002. Oxford: Claredon Press, 2002. p. 171.

${ }^{282}$ SCHERMAIER, Martin Joseph. Mistake, misrepresentation and precontractual duties to inform: the civil law tradition. In: SEFTON-GREEN, Ruth (Ed.). op. cit., p. 62.

${ }^{283}$ Uma vez invalidado o contrato, em razão de vício de consentimento, a parte prejudicada tinha que contentar-se com a recuperação do status quo ante. Não se cogitava, portanto, de nenhuma obrigação em relação ao causador do dano na fase pré-contratual, porque contrato inválido não gera efeitos. Nesse contexto, assevera Jhering que o causador da anulação do contrato ou da ruptura das negociações, embora desobrigado da prestação entabulada ou convencionada, em face da anulação ou da ruptura prévia, é responsável pela reparação dos danos. Essa pretensão indenizatória da parte prejudicada não pode, pois, fundar-se no interesse positivo representado pelo cumprimento do contrato, mas no interesse negativo de não concluí-lo, e, por isso mesmo, reparar os prejuízos causados. JHERING, Rudolf von. Culpa in contrahendo ou indemnização em contratos nulos ou não chegados à perfeição. Trad. Paulo Mota Pinto. Coimbra: Almedina, 2008. p. 15-17 passim.
} 
teoria, caracterizada a culpa in contrahendo, e constatados os prejuízos daí decorrentes para a contraparte, o causador do dano será responsável pela respectiva indenização, independentemente de não interessar à parte contrária o cumprimento das obrigações pactuadas, seja porque ainda não aperfeiçoado o contrato, seja em razão de sua anulação (interesses negativos).

Na Alemanha, como na Áustria, Suíça, Itália e França, a doutrina da culpa in contrahendo conquistou um campo novo e amplo, diverso da teoria do erro, pois este só permite a invalidação do negócio jurídico, e não a reparação do dano causado pela infração do dever legal. ${ }^{284}$

A despeito da limitação da literalidade do $\S 242$, do $B G B$, que, tratando da prestação da obrigação, dispõe que o devedor está obrigado a executá-la como exige a boafé, levando em consideração os usos e costumes, ${ }^{285}$ seu significado foi estendido muito além de seus limites semânticos, e acabou representando uma ameaça à segurança jurídica e servindo de pretenso fundamento para ideias totalitárias. ${ }^{286}$ A aplicação da regra do $§ 242$ é frequentemente combinada com a norma do $\S 157$, do $B G B$, que trata da interpretação: $o s$

\footnotetext{
${ }^{284}$ SCHERMAIER, Martin Joseph. op. cit., p. 63.

${ }^{285} \$ 242$. Performance in good faith: An obligor has a duty to perform according to the requirements of good faith, taking customary practice into consideration.

${ }^{286}$ ZIMMERMAN e WHITTAKER comentam a adoção do princípio da boa-fé como fundamento de uma decisão do Tribunal Imperial, em 1923, que estendeu indevidamente o conteúdo do § 242 BGB, para afastar a possibilidade de extinção de dívida em moeda alemã, devido à elevadíssima taxa de inflação. Para impedir que um devedor se liberasse do pagamento da dívida contraída antes da Primeira Guerra Mundial mediante pagamento em moeda nacional, que não mais detinha poder aquisitivo algum (1 marco de ouro era trocado por DM 522 bilhões) o Tribunal teve que afastar a aplicação do princípio do valor nominal da moeda, e estabeleceu uma nova taxa de câmbio, diante da inação do Legislativo, invocando, para tanto, § 242 BGB, como uma estaca positivista. Argumentou-se que a desvalorização imprevisível do marco havia dado origem a um conflito entre o princípio do valor nominal, consubstanciado na lei, e o que poderia ser esperado, em boa fé, do devedor em relação à quitação de suas obrigações. Diante do conflito, o Tribunal estabeleceu a prevalência do $\S 242$ BGB que, afinal de contas, afastou a legislação relativa à circulação monetária que não mais podiam ser conciliadas com os preceitos da boa-fé. Essa decisão abalou o mundo jurídico, pois, além de a fixação de taxas de câmbio certamente não ser de competência do Poder Judiciário, era inconciliável com a exceptio doli generalis, mesmo em sua versão mais estendida. Se as provisões legais gerais pudessem ser usadas para justificar este tipo de intervencionismo, estava aberta a possibilidade para uma perigosa utilização desautorizada boa-fé. Esse receio foi confirmado pelo que aconteceu após 1933. As provisões gerais constituíram um ponto de partida para impregnar o sistema legal com o espírito da nova, e 'nacional' ideologia nazista, embora atualmente o sistema jurídico alemão se tenha livrado da influência daquela ideologia, à custa, principalmente, do incremento dos direitos fundamentais que impuseram o respeito à dignidade humana e à liberdade individual, valores que impregnam todo o sistema legal. Mas o fato de o princípio da boa-fé se ter prestado a fundamentar o ideário nazista já confirma a inconveniente extensão que lhe foi indevidamente atribuída. ZIMMERMAN, Reinhard; WHITTAKER, Simon (Eds.). op. cit., p. 20-21.
} 
contratos devem ser interpretados segundo a exigência da boa-fé, levando-se em consideração os usos e costumes. ${ }^{287}$

O $\S 313, B G B$, se refere à cláusula rebus sic stantibus, prevendo a possibilidade de resolução do negócio por onerosidade excessiva causada por circunstâncias imprevistas, que provocam a ruptura da base do negócio; o $§ 320$, do $B G B$, trata da exceção do contrato não cumprido, invocando a boa-fé como critério de apreciação da recusa no cumprimento da obrigação ou de parte dela.

A frequência com que os tribunais recorriam ao princípio da boa-fé e a abrangência excessiva que lhe emprestaram provocaram sua hipertrofia. Mas, com o tempo, a jurisprudência do Supremo Tribunal Federal (BGH - Bundesgerichtshof) levou a uma concretização mais racional e ordenada do princípio da boa-fé. Atualmente, o $\S 242$ BGB tem efeito supletivo da lei, estabelecendo um padrão para o desempenho dos contratantes e albergando deveres complementares, que se aplicam antes e depois da conclusão do contrato. $^{288}$

A relevância dos preceitos da boa-fé está associada à determinação do alcance das infrações de deveres auxiliares que levam à responsabilidade pelos danos. A responsabilidade por culpa in contrahendo pode ser vista como uma emanação do $§ 242$ $B G B$, que opera como fundamento dos deveres especiais.

Muitas instituições jurídicas baseadas no $§ 242$ BGB ganharam autonomia e passaram a ser consideradas independentemente da boa-fé, que se limita atualmente a servir-lhes de fundamento. Porém, como o princípio também é invocado para limitar o exercício de direitos, quando não usado com parcimônia, pode abrir espaço para interferências indevidas nas relações contratuais. ${ }^{289} \mathrm{O} \S 122^{290}$ BGB responsabiliza o contratante por declarações na fase pré-contratual. Com a alteração legislativa do direito obrigacional, foram incluídos outros dispositivos que prescrevem deveres de informação (§

\footnotetext{
${ }^{287} \$$ 157. Interpretation of contracts: Contracts are to be interpreted as required by good faith, taking customary practice into consideration.

${ }^{288}$ ZIMMERMAN, Reinhard; WHITTAKER, Simon (Eds.). op. cit., p. 23-24.

${ }^{289}$ Id. Ibid., p. 24-26.

${ }^{290} \$$ 122. Liability in damages of the person declaring avoidance. (1)If a declaration of intent is void under section 118, or avoided under sections 119 and 120, the person declaring must, if the declaration was to be made to another person, pay damages to this person, or failing this to any third party, for the damage that the other or the third party suffers as a result of his relying on the validity of the declaration; but not in excess of the total amount of the interest which the other or the third party has in the validity of the declaration. (2)A duty to pay damages does not arise if the injured person knew the reason for the voidness or the voidability or did not know it as a result of his negligence (ought to have known it).
} 
$241(2)^{291}$ e $\S 311^{292}$ BGB). Também foram impostos deveres específicos de informação nas relações de consumo, tratando de contratos celebrados à distância (§ 312c), ${ }^{293}$ disposição sobre conteúdo, duração, eficácia da garantia e inteligibilidade dos termos do certificado $(\S 477)^{294}$, disposições específicas sobre contratos de time sharing $(\S 482)^{295}$, e sobre informações e condições em contratos de crédito $(\S 502){ }^{296}$

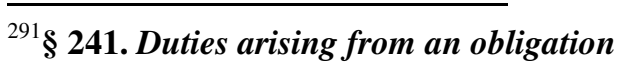

(1)By virtue of an obligation an obligee is entitled to claim performance from the obligor. The performance may also consist in forbearance.

(2)An obligation may also, depending on its contents, oblige each party to take account of the rights, legal interests and other interests of the other party.

${ }^{292} \$ 311$. Obligations created by legal transaction and obligations similar to legal transactions

(1)In order to create an obligation by legal transaction and to alter the contents of an obligation, a contract between the parties is necessary, unless otherwise provided by statute.

(2)An obligation with duties under section 241 (2) also comes into existence by

1. the commencement of contract negotiations

2. the initiation of a contract where one party, with regard to a potential contractual relationship, gives the other party the possibility of affecting his rights, legal interests and other interests, or entrusts these to him, or

3. similar business contacts.

(3)An obligation with duties under section 241 (2) may also come into existence in relation to persons who are not themselves intended to be parties to the contract. Such an obligation comes into existence in particular if the third party, by laying claim to being given a particularly high degree of trust, substantially influences the pre-contract negotiations or the entering into of the contract.

${ }^{293}$ (1)The entrepreneur must give information to the consumer with distance contracts under Article 246 sections (1) and (2) of the Introductory Act to the German Civil Code [Einführungsgesetz zum Bürgerlichen Gesetzbuch]. (2) In telephone calls arranged by himself, the entrepreneur must at the beginning of every conversation expressly disclose his identity and the business purpose of the contact. (3)In the case of financial services, the consumer may demand at any time in the duration of the contract that the entrepreneur provides him with the terms of the contract, including the standard business terms, in a document. (4)More extensive restrictions in the use of means of distance communication and more extensive duties to provide information under other provisions are unaffected.

${ }^{294}$ (1)A declaration of guarantee (section 443) must be expressed simply and comprehensibly. It must contain 1. a reference to the statutory rights of the consumer and a statement that they are not restricted by the guarantee, and 2. the contents of the guarantee and all essential information required for asserting rights under the guarantee, including, without limitation, the duration and the area of territorial application of the guarantee protection as well as the name and address of the guarantor. (2)The consumer may demand that the declaration of guarantee is given to him in text form. (3)The effectiveness of the duty under the guarantee is not affected by the fact that one of the above requirements is not satisfied.

${ }^{295}$ (1) The entrepreneur must provide to the consumer in good time prior to the submission of his contract declaration on the conclusion of a time-share agreement, of a contract relating to a long-term holiday product, of a brokerage contract or of an exchange system contract preliminary contract information under Article 242 section 1 of the of the Introductory Act to the Civil Code [Einführungsgesetz zum Bürgerlichen Gesetzbuche] in text form. These must be clear and comprehensible. (2) Any advertising for such contracts must state that preliminary contract information is available and where this can be requested. When inviting to advertising or sales events, the entrepreneur must clearly indicate the commercial nature of the event. The consumer must be provided at such events with the preliminary contract information at any time. (3) A time-share agreement or a right from a contract relating to a long-term holiday product may not be advertised or sold as an investment.

${ }^{296}$ (1) The lender may in the case of early repayment require suitable compensation for early termination for the damage directly related to early repayment if the borrower at the time of repayment owes interest at a pegged lending rate agreed on conclusion of the contract. The compensation for early termination may not exceed the following amounts in each case: 1.1 percent or, if the period between the early and the agreed repayment is not more than one year, 0.5 percent of the amount repaid early, 2. the amount of the interest which the borrower would have paid in the period between early and agreed repayment. (2) The right to compensation for early termination is ruled out if 1 . the repayment is effected from funds from an insurance 
Atribui-se ao tratamento jurisprudencial do princípio da boa-fé a origem do controle judicial das cláusulas contratuais gerais, ${ }^{297}$ que resultou nas provisões do $A G B$ Gezetz. ${ }^{298}$ A disciplina das predisposições dos contratos padronizados, estabelece entre outras provisões concebidas anteriormente pela jurisprudência, a invalidade da cláusula que viola os preceitos da boa-fé, colocando a contraparte em situação desvantajosa.

Constatam Zimmerman e Whittaker que, tendo despertado tanta controvérsia, a boa-fé não é, como se alardeava na Inglaterra, nem a rainha das normas, nem a praga funesta. Se usada criteriosamente, sua flexibilidade e adaptabilidade a transformam num instrumento muito útil à missão dos tribunais de especificar, complementar e modificar a lei, adequando-a às necessidades de seu tempo. ${ }^{299}$

Resumindo a orientação jurisprudencial alemã, Kötz anota que, em princípio, subsiste o dever de informar à contraparte fatos que frustrariam seu objetivo de contratar e que são, portanto, de vital importância, na medida em que ela esperaria ser informada de acordo com as boas práticas negociais. Kötz cita um processo paradigmático julgado em 1994, em que o réu tinha cedido aos autores uma licença de direito de transmissão de uma série da TV americana, reservando-se o equivalente a $50 \%$ do produto de qualquer sublicença que os autores conseguissem em relação às televisões alemãs. Depois o réu renunciou a este direito, cedendo-o aos autores por U\$10.000. Em seguida, tentou voltar atrás, sob o fundamento de que os autores tinham omitido, durante as negociações, que já tinham recebido oferta de DM 8.3 milhões pela sublicença. As instâncias inferiores entenderam que os autores não tinham dever de informar e que o réu não tinha o direito de anular o negócio com base na alegada omissão dolosa. Porém, o Supremo Tribunal Federal (Bundesgerichtshof) reverteu a decisão para favorecer o réu, sob o fundamento de que as partes tinham uma relação negocial duradoura e próxima, que, por isso, comportaria o dever de informar a contraparte. Kötz critica a posição adotada no julgamento definitivo, argumentando que, sendo o réu um profissional do ramo, e o negócio, proposto por ele próprio, claramente especulativo, seria ônus dele descobrir que o mercado era melhor do que ele supunha. ${ }^{300}$ Justificada, a nosso ver, a crítica de Kötz, porque a decisão discutida

policy concluded on the basis of a corresponding obligation in the loan contract in order to ensure repayment, or 2. the information contained in the contract on the term of the contract, the right of termination of the borrower or the calculation of the compensation for early termination is inadequate.

${ }^{297}$ Arts. 305 a 310, especialmente os artigos 307 e 309.

${ }^{298}$ Allgemeinen Geschäftsbedingungen (AGB-Gesetz)

${ }^{299}$ ZIMMERMAN, Reinhard; WHITTAKER, Simon (Eds.). op. cit., p. 32.

${ }^{300}$ KÖTZ, Hein. Precontractual duties of disclosure: a comparative and economic perspective. European Journal of Law and Economics, n. 9, p. 3-4, 2000. 
desconsidera a natural contraposição de interesses entre contratantes, que não estão obrigados manter a solidariedade fiduciária, típica das relações de agência, em que o agent tem dever de absoluta fidelidade em relação ao principal, como na parceria, na sociedade, no mandato, no contrato de trabalho, nem se trata de contrato uberrimae fidei, como o de seguro. Ressalvadas essas exceções e algumas situações excepcionais detectadas no caso concreto, deveria prevalecer a regra de que a cada um incumbe o ônus de informar-se, assumindo o risco da desinformação.

\section{Direito Italiano}

O Código Civil de 1865 já previa a boa-fé como padrão de conduta para os contratantes (art. 1124). Embora seus intérpretes, seguindo a abordagem francesa, fossem inicialmente hostis à exceptio doli generalis, a partir da virada do século, começaram a se interessar pela doutrina legal alemã. ${ }^{301}$

O Código Civil de 1942 incorporou essa guinada doutrinária, submetendo as negociações pré-contratuais, a formação (art. $1337^{302}$ e art. $1338^{303}$ ), a interpretação (art. $1366^{304}$ ) e a execução do contrato (art. $1375^{305}$ ) ao padrão de boa fé. O art. 1337 impõe dever de lealdade na formação do contrato, desvendando à contraparte informação relevante e verdadeira e apontando-lhe eventual erro reconhecível, pois os deveres précontratuais abrangem do erro à reticência dolosa. ${ }^{306} \mathrm{O}$ artigo 1.338 constitui um desenvolvimento do dever de lealdade previsto no art. 1337. Tratando especificamente da disparidade de informação entre as partes, e tutelando a confiança, estabelece a responsabilidade da parte que sabe de causa de invalidade do contrato e a omite da outra. $\mathrm{O}$ principio da boa-fé, expressamente estendido para alcançar as relações pré-contratuais (art. 1337 CC), abrange evidentemente o dever de informação. Comentam Schäfer e Ott que a

\footnotetext{
${ }^{301}$ ZIMMERMAN, Reinhard; WHITTAKER, Simon (Eds.). op. cit., p. 52.

${ }^{302}$ Art. 1337. Trattative e responsabilità precontrattuale: Le parti, nello svolgimento delle trattative e nella formazione del contratto, devono comportarsi secondo buona fede (1366,1375, 2208).

${ }^{303}$ Art. 1338 Conoscenza delle cause d'invalidità: La parte che, conoscendo o dovendo conoscere l'esistenza di una causa d'invalidità del contratto (1418 e seguenti), non ne ha dato notizia all'altra parte è tenuta a risarcire il danno da questa risentito per avere confidato, senza sua colpa, nella validità del contratto (1308).

${ }^{304}$ Art. 1366. Interpretazione di buona fede: Il contratto deve essere interpretato secondo buona fede (1337,1371,1375).

${ }^{305}$ Art. 1375. Esecuzione di buona fede: Il contratto deve essere eseguito secondo buona fede (1337,1358,1366, 1460).

${ }^{306}$ BETTI, Emilio. Teoria generale delle obbligazioni: prolegomeni, funzione economico-soziale dei rapporti d'obbligazione. Milano: Giuffrè. 1953. v. 1, p. 82.
} 
rescisão, como remédio para a omissão, é restrita aos casos de dolo. ${ }^{307} \mathrm{O}$ art. 1366 concerne à cláusula geral de interpretação e integração dos contratos. E o art. 1375 estende o princípio da boa-fé, que, na fase da execução implica cooperação entre as partes.

A lei italiana também contém provisão específica sobre a teoria da imprevisibilidade voltada à noção de onerosidade excessiva (art. $1467^{308}$ ), que Zimmerman e Whittaker consideram confirmação do princípio de boa fé, que também está arraigado em outros dispositivos do código. E os acadêmicos italianos, sob inspiração da doutrina alemã, se encarregaram de estender a aplicação da boa-fé aos casos não cobertos especificamente pela legislação. Mas o legado positivista contribuiu para a relutância da doutrina italiana de adotar, integralmente, o papel criativo e corretivo da boa fé, limitando-se a acolhê-la em um nível mais abstrato. ${ }^{309}$

Depois do advento do Código de 1942, a doutrina contratual italiana passou a substituir a ideia da conjunção de vontades para a formação do contrato, pela teoria da declaração, focada na proteção da expectativa da parte que confiou na promessa declarada pela contraparte, como sustenta Rodolfo $\mathrm{SACCO}^{310}$. De acordo com esta abordagem, o princípio da boa-fé passou a ser interpretado pelos juristas como sinônimo de Treu und Glauben, apesar de a jurisprudência ser mais refratária ao princípio, por conferir muita importância à liberdade contratual. ${ }^{311}$

Levou tempo para que a ideia de boa-fé, impregnada que fora pelo ideário fascista se livrasse do ranço ideológico e da fama pejorativa que a maculavam.

Até o começo dos anos setenta a orientação jurisprudencial predominante da Suprema Corte não acolhia o princípio da boa-fé como fundamento autônomo para ação

\footnotetext{
${ }^{307}$ SCHÄFER, Hans-Bernd; OTT, Claus. The economic analysis of civil law, cit., p. 390.

${ }^{308}$ Art. 1467. Contratto con prestazioni corrispettive.

Nei contratti a esecuzione continuata o periodica ovvero a esecuzione differita, se la prestazione di una delle parti è divenuta eccessivamente onerosa per il verificarsi di avvenimenti straordinari e imprevedibili, la parte che deve tale prestazione può domandare la risoluzione del contratto, con gli effetti stabiliti dall'art. 1458 (att. 168).

La risoluzione non può essere domandata se la sopravvenuta onerosità rientra nell'alea normale del contratto.

La parte contro la quale è domandata la risoluzione pù̀ evitarla offrendo di modificare equamente le condizioni del contratto $(962,1623,1664,1923)$.

${ }^{309}$ ZIMMERMAN, Reinhard; WHITTAKER, Simon (Eds.). op. cit., p. 53.

${ }^{310}$ SACCO, Rodolfo; DE NOVA, Giorgio. op. cit., v. 1, p. 167.

${ }^{311}$ MUSY, Alberto M. The Good faith principle in contract law and the precontractual duty to disclose: comparative analysis of new differences in legal cultures. Global Jurist Advances, v. 1, n. 1, p. 5, 2000. Disponível em: < http://www.bepress.com/gj/advances/vol1/iss1/art1>.
} 
judicial, linha que, segundo o autor, ainda subsiste, e os dispositivos atinentes ao princípio eram usados pelos tribunais mais para enfatizar a proteção dos direitos subjetivos. ${ }^{312}$

A partir do final da década de setenta, a jurisprudência passou a reconhecer o princípio da boa-fé como base para fundamentar pretensões judiciais relativas aos deveres de informação e de proteção dos interesses da parte contrária. ${ }^{313}$

Musy constata que atualmente os juristas italianos são céticos em relação ao uso jurisprudencial do princípio da boa-fé, na medida em que pode ser usado para finalidade redistributiva e que, se transforma em instrumento de aplicação indiscriminada de equidade, conferindo exagerada discricionariedade aos juízes. E pondera que a doutrina italiana não ofereceu aos tribunais quadro claro e sistemático do padrão de boa-fé. ${ }^{314}$

\section{Direito Francês}

A norma programática ${ }^{315}$ do art. $1134^{316}$, do Código Civil, obrigou a doutrina francesa a buscar formas criativas para viabilizar a aplicação do princípio da boa-fé e os deveres contratuais a ela associados. Até o final do século XIX, não se aplicava nem a equidade nem a boa-fé às relações contratuais, pois prevalecia a ideia da autonomia da vontade, que não deixava espaço para que boa fé exercesse papel relevante no domínio dos contratos. $^{317}$

$\mathrm{O}$ art. $1135^{318}$ dispôs que as convenções obrigam não só em relação ao que nelas está expresso, mas também em relação a tudo aquilo que a equidade, os usos e costumes e a lei atribuem à obrigação, de acordo com a sua natureza. ${ }^{319}$ Este dispositivo legal serviu de fundamento para a interpretação das obrigações de segurança implícitas nos contratos, nas relações de trabalho, tal como invocado pela doutrina, como para contratos de transporte, por criação jurisprudencial. Essa interpretação baseada em equidade permitiu

\footnotetext{
${ }^{312}$ MUSY, Alberto M. op. cit., p. 5-6.

${ }^{313}$ Id. Ibid.

${ }^{314}$ Id. Ibid., p. 6.

${ }^{315}$ SACCO, Rodolfo. Legal formants: a dynamic approach to comparative law. American Journal of Comparative Law, v. 39, n. 1, 1991, MUSY, Alberto M. op. cit., p. 2.

${ }^{316}$ Article 1134. Les conventions légalement formées tiennent lieu de loi à ceux qui les ont faites.

Elles ne peuvent être révoquées que de leur consentement mutuel, ou pour les causes que la loi autorise.

Elles doivent être exécutées de bonne foi.

${ }^{317}$ ZIMMERMAN, Reinhard; WHITTAKER, Simon (Eds.). op. cit., p. 33.

${ }^{318}$ Article 1135. Les conventions obligent non seulement à ce qui y est exprimé, mais encore à toutes les suites que l'équité, l'usage ou la loi donnent à l'obligation d'après sa nature.

${ }^{319}$ ZIMMERMAN, Reinhard; WHITTAKER, Simon (Eds.). op. cit., p. 33.
} 
aos tribunais uma interação flexível entre contrato e delito, representando a aplicação pioneira da equidade na execução contratual. ${ }^{320}$

Mas a análise jurídica do contrato focalizava o acordo com o objetivo de detectar eventuais vícios de consentimento, que eram interpretados extensivamente. Neste contexto, a boa-fé nos contratos era interpretada como estrita adesão das partes ao pactuado, no qual valiam mais as intenções do que as declarações. Boa-fé e equidade não eram vistas como qualificadoras do contrato, ${ }^{321}$ porque, segundo conhecido aforismo da época, o que é contratado, é justo. ${ }^{322}$

No início do século XX, por influência do código alemão e do suíço, o direito francês começou a cogitar de uma teoria do abuso de direito, que se caracterizava se o direito fosse exercido com intenção de prejudicar outrem ou de forma a contrariar seu objetivo econômico ou social. Esta concepção foi bem aceita na França, apesar de reconhecidamente afetar o cerne da concepção liberal dos direitos subjetivos, e aumentar demais a margem de discricionariedade judicial, gerando incerteza jurídica. O instituto do abuso de direito, no âmbito contratual foi considerado um desenvolvimento do art. 1134, e se entrelaçou ao princípio da boa-fé. Na fase pré-contratual, abuso e má-fé são vistos pelo prisma da responsabilidade extracontratual. ${ }^{323}$

Até o final da década de setenta, a trajetória do direito francês era paralela à do direito inglês, que prestigiava o modelo econômico liberal, e sustentava que, como o contrato envolvia interesses geralmente conflitantes, cada parte zelaria pelos seus e arcaria com o ônus de informar-se, e com os riscos daí decorrentes. ${ }^{324}$ Esse era o principal fundamento da resistência doutrinária e jurisprudencial francesa à adoção da boa-fé como padrão de conduta ou como cláusula geral. Assim como no direito inglês, à regra básica de que a cada contratante incumbia informar-se, se excepcionavam poucas hipóteses de imposição do dever de informação, como, por exemplo, nos contratos de compra-e-venda,

\footnotetext{
${ }^{320}$ ZIMMERMAN, Reinhard; WHITTAKER, Simon (Eds.). op. cit., p. 35-36.

${ }^{321} \mathrm{O}$ Código Civil francês prestigiou a auto-responsabilidade, derivada da autonomia privada, e tratou com objetividade da inexecução da obrigação, excepcionando somente o inadimplemento por força maior. E não permitiu que o desequilíbrio das prestações, original ou superveniente, pudesse afetar a força vinculante do contrato. Id. Ibid., p. 35-36.

${ }^{322}$ Tradução livre do aforismo qui dit contractuel dit juste, o qual equivale ao nosso conhecido ditado popular - o que é trato não é caro, que confirma a ideia de que o cumprimento dos contratos é um relevante objetivo social e deve ser incentivado.

${ }^{323}$ Id. Ibid., p. 34-35.

${ }^{324}$ Como dizia Ripert, "chacun est le gardien de ses propres intérêts e doit par conséquent se renseigner luimême”. RIPERT, Georges. La règle morale dans les obligations civiles. 4. ed. Paris: LGDJ, 1949. p. 89.
} 
em que se previa, desde a promulgação do Código de Napoleão (1804), a responsabilidade do vendedor em relação à evicção e aos vícios redibitórios (arts. 1626 e 1641). ${ }^{325}$

A partir do final da década de setenta, com o declínio da ideologia liberal e a ascensão do postulado da solidariedade contratual, expandiu-se o dogma da boa-fé estendendo-se sua aplicação à formação dos contratos, e estabelecendo um padrão contraposto ao princípio da autonomia dos contratantes, impondo-lhe limites. Os adeptos desse 'solidarismo' emergente concebiam o contrato como cooperação e não como uma articulação de interesses antagônicos. Com isso, o dever de informação, baseado na boa-fé (art. 1134 CC), passou a ser exigido também nas negociações pré-contratuais. Porém, a jurisprudência desviava do fundamento da boa-fé, recorrendo às regras clássicas da responsabilidade civil (art.1382 $2^{326}$ ) e dos vícios de consentimento (arts. $1110^{327}$ e $\left.1116^{328}\right)^{329}$

Mas o avanço tecnológico dividiu os contratantes em profissionais e leigos, e, dada a assimetria informacional entre essas categorias, os leigos são compelidos a depender dos profissionais e confiar na sua expertise. Por isso, segundo Legrand $\mathrm{Jr}$, a omissão de informações prejudica não só o contratante negligente ou imprudente, mas toda a massa de consumidores sem conhecimento técnico. ${ }^{330} \mathrm{O}$ autor lista os pressupostos para a aplicação do dever de informar: i) assimetria informacional derivada do status das partes, uma sendo profissional e a outra leiga; ii) legítima dependência ou confiança do leigo no profissional; iii) fato relevante concernente ao objeto do contrato que o profissional conhece ou deveria conhecer, e que pode afetar a decisão de contratar do leigo. ${ }^{331}$ Entretanto, o autor restringe seus critérios ao status dos contratantes, sempre contrapondo o contratante profissional ao

\footnotetext{
${ }^{325}$ Article 1626. Quoique lors de la vente il n'ait été fait aucune stipulation sur la garantie, le vendeur est obligé de droit à garantir l'acquéreur de l'éviction qu'il souffre dans la totalité ou partie de l'objet vendu, ou des charges prétendues sur cet objet, et non déclarées lors de la vente.

Article 1641. Le vendeur est tenu de la garantie à raison des défauts cachés de la chose vendue qui la rendent impropre à l'usage auquel on la destine, ou qui diminuent tellement cet usage que l'acheteur ne l'aurait pas acquise, ou n'en aurait donné qu'un moindre prix, s'il les avait connus.

${ }^{326}$ Article 1382. Tout fait quelconque de l'homme, qui cause à autrui un dommage, oblige celui par la faute duquel il est arrivé à le réparer.

${ }^{327}$ Article 1110. L'erreur n'est une cause de nullité de la convention que lorsqu'elle tombe sur la substance même de la chose qui en est l'objet.

Elle n'est point une cause de nullité lorsqu'elle ne tombe que sur la personne avec laquelle on a intention de contracter, à moins que la considération de cette personne ne soit la cause principale de la convention.

${ }^{328}$ Article 1116. Le dol est une cause de nullité de la convention lorsque les manoeuvres pratiquées par l'une des parties sont telles, qu'il est évident que, sans ces manoeuvres, l'autre partie n'aurait pas contracté.

Il ne se présume pas et doit être prouvé.

${ }^{329}$ MUSY, Alberto M. op. cit., p. 3.

${ }^{330}$ LEGRAND JR, Pierre. Pre-contractual disclosure and information: english and french law Compared. Oxford Journal of Legal Studies, v. 6, n. 3, p. 322-352, 1986.

${ }^{331}$ Id. Ibid., p. 338.
} 
leigo. Embora admita, em tese, a eventual inversão de papéis entre os dois, mesmo assim não reconhece o dever de informar do leigo, porque só cogita da informação que classifica como 'tecnológica', e sustenta que o status dos contratantes prevalece sobre a natureza do contrato. Limitando seu argumento estritamente ao status das partes, numa contraposição um tanto maniqueísta, reduziu indevidamente o âmbito de aplicação do dever de informar, desconsiderando que a assimetria informacional alcança fatos relevantes concernentes não só aos aspectos técnicos, mas aos aspectos fáticos do objeto do contrato e às qualidades da contraparte contratante, seja ela leiga ou profissional, consumidor ou fornecedor.

O dever de informar se aplica aos contratos em que se exige solidariedade fiduciária dos contratantes, típica das mencionadas relações de agência, como nos contratos de sociedade e de parceria, nos contratos de uberrima fides, como o de seguro, ${ }^{332}$ nas relações trabalhistas, e nas de consumo, ${ }^{333}$ devido às peculiaridades dessas relações contratuais.

Em matéria de responsabilidade civil, a omissão pode também acarretar indenização por perdas e danos nos casos de negligência (art. 1382 CC), embora, segundo Schäfer e Ott, a jurisprudência geralmente relute em punir a omissão pré-contratual com base em responsabilidade civil. Só a omissão dolosa pode acarretar a invalidade do contrato. $^{334}$

A despeito da apontada obsessão francesa mais com a moralidade do que com a eficiência da lei, Fabre-Magnan ${ }^{335}$ comenta que desenvolvimentos recentes do dever de informar ${ }^{336}$ tendem a mudar o panorama do direito francês em relação à análise econômica do problema da informação.

\footnotetext{
${ }^{332}$ Nas relações de seguro privado, a lei impôs ao segurado especial dever de transparência e veracidade, tanto na fase pré-contratual, como durante a execução do contrato, devido à natureza deste. Code des Assurances, art. L $113-2$.

${ }^{333}$ SCHÄFER, Hans-Bernd; OTT, Claus. The economic analysis of civil law, cit., p. 390. Apesar da concepção francesa da força vinculante dos contratos, as cláusulas abusivas, especialmente a de isenção de responsabilidade, foram tratadas com rigor, instituindo-se várias formas de invalidá-las. E a emenda de 1975 ao Código Civil permitiu a redução ou aumento da cláusula penal, se a convencionada fosse manifestamente excessiva ou irrisória. Em 1978 foi autorizada a edição normas para banir cláusulas abusivas em contextos específicos, como nas relações de consumo. Mas diante da inação do legislativo, os tribunais decretavam a anulação das cláusulas consideradas abusivas. Só com a implementação, em 1996, da Diretiva n. 13 de 1993, concernente às relações de consumo, foi estabelecida a base legal para o controle judicial das cláusulas abusivas. ZIMMERMAN, Reinhard; WHITTAKER, Simon (Eds.). op. cit., p. 37.

${ }^{334}$ SCHÄFER, Hans-Bernd; OTT, Claus. The economic analysis of civil law, cit., p. 390.

${ }^{335}$ FABRE-MAGNAN, Muriel. Duties of disclosure and french contract law: contribution for an economic analysis. In: BEATSON, Jack; FRIEDMANN, Daniel (Eds.). Good faith and fault in contract law. 1995, rep. 2002. Oxford: Claredon Press, 2002. p. 108.

${ }^{336}$ RUDDEN, Bernard. Le juste et le inefficace pour un non-devoir de renseignements. Revue Trimestrielle de Droit Civil, Paris, n. 84, p. 91-103, 1985.
} 
Recentemente, a teoria da informação atingiu certo grau de independência e unicidade, que a emancipou da boa-fé ${ }^{337}$, e foi enfatizada pela disciplina dos contratos de consumo. $^{338}$

Legrand Jr. aponta a tendência do direito francês de reconhecer a autonomia do dever de informar, e de tentar formular novo modelo detalhado para o instituto. ${ }^{339}$

Apesar do esforço da doutrina francesa no sentido de torná-lo mais consistente, o princípio da boa-fé ainda é afetado pela suspeita do risco de alargar a discricionariedade judicial em relação à tradicional abordagem do direito positivo. Ademais, tanto a doutrina como a jurisprudência não têm feito distinção clara entre a boa-fé subjetiva e a objetiva, especialmente nos casos de omissão dolosa e erro essencial. ${ }^{340}$ A doutrina francesa está dividida em relação ao impacto da boa fé no direito contratual, embora reconheça sua importância como base legal para a construção jurisprudencial dos deveres contratuais de lealdade e cooperação. Até os juristas adeptos do princípio da boa-fé concordam em que sua aplicação não deve conduzir à imposição de altruísmo absoluto, que seria a negação dos interesses individuais. ${ }^{341}$

Endossando a conclusão de Patrice Jourdain, Zimmerman e Whittaker asseveram que a boa fé continua sendo uma noção nebulosa, que só é efetivamente compreendida

\footnotetext{
${ }^{337}$ Segundo Legrand Jr, mesmo tendo reconhecido um dever autônomo de informar, cuja violação acarreta responsabilidade extracontratual, esta abordagem ainda é exceção. Por isso, os tribunais ainda recorrem tanto aos vícios de consentimento, contentando-se com a voluntariedade do ato (dolo), em vez de exigir prova da manifesta intenção de enganar. LEGRAND JR, Pierre. op. cit., p. 338. Mas o fato de os tribunais se contentarem com a prova da voluntariedade do ato também pode ser atribuida ao fato de que voluntariedade de um ato se demonstra mais facilmente, até por presunção, enquanto intenção (manifesta) de enganar é muito mais difícil de comprovar, até porque má-fé tradicionalmente não se presume.

${ }^{338}$ ZIMMERMAN, Reinhard; WHITTAKER, Simon (Eds.). op. cit., p. 36. A legislação referida pelos autores é a Lei n. 60/92 (art. 2), derrogada pelo Código do Consumidor, e alterada pela 1. 853/2010, referente ao regime da informação na relação de consumo:

Article L111-1 C. Cons. (Modifié par LOI n²010-853 du 23 juillet 2010 - art. 35 I.)

I - Tout professionnel vendeur de biens doit, avant la conclusion du contrat, mettre le consommateur en mesure de connaître les caractéristiques essentielles du bien.

II - Le fabricant ou l'importateur de biens meubles doit informer le vendeur professionnel de la période pendant laquelle les pièces indispensables à l'utilisation des biens seront disponibles sur le marché. Cette information est obligatoirement délivrée au consommateur par le vendeur, avant la conclusion du contrat.

III. - En cas de litige portant sur l'application des I et II, il appartient au vendeur de prouver qu'il a exécuté ses obligations.

${ }^{339}$ LEGRAND JR, Pierre. op. cit., p. 349. Reporta decisões jurisprudenciais da década de oitenta, em que os tribunais extrapolaram a tradição clássica e impuseram o dever de informar, sem qualquer referência aos vícios de consentimento, o autor pondera que esta evolução da forma indireta para o reconhecimento direto do instituto é conveniente, pois implicitamente admite que a nulidade do contrato nem sempre é a solução mais adequada, porque nem sempre é possível a restituição integral ao estado anterior. Id. Ibid., p. 335.

${ }^{340}$ MUSY, Alberto M. op. cit., p. 3.

${ }^{341}$ Zimmerman e Whittaker reproduzem uma crítica jocosa de Carbonnier a Demogue, entusiasta do princípio boafé, aduzindo que, numa época em que o casamento já se transformou em contrato, tem gente sonhando em transformar o contrato em casamento. ZIMMERMAN, Reinhard; WHITTAKER, Simon (Eds.). op. cit., p. 38.
} 
quando combinada com conceitos de conteúdo mais preciso. Esta fraqueza congênita tem origem na natureza imprecisa da noção que, na prática, se mantém essencialmente moral, e que foi transformada em uma norma de comportamento para reger relações contratuais. ${ }^{342}$

\section{Direito Inglês}

$\mathrm{O}$ direito inglês não adota o princípio da boa-fé como padrão de conduta dos contratantes em geral, nem reconhece, como regra, deveres pré-contratuais, inclusive o de prover informação à contraparte. Ressalvadas as exceções que serão destacadas, vale o princípio consubstanciado no brocardo caveat emptor. Uma decisão judicial sempre citada como paradigmática da óptica inglesa é o caso Walford v. Miles ${ }^{343}$, em que os juízes rejeitaram, por unanimidade, os deveres pré-contratuais aplicados às tratativas e fundados no princípio da boa-fé, argumentando ser incompatível com a natural contraposição dos interesses das partes envolvidas em negociações preliminares ao contrato. Neste caso, relativamente recente (1992), foi considerada impraticável a aplicação do princípio de boafé à fase pré-contratual, em relação à qual é inerente a busca da satisfação dos próprios interesses pelas partes.

A teoria do abuso de direito, criada e aplicada com sucesso na França, não foi adotada pelos ingleses, cuja abordagem liberal se reflete também no exercício dos direitos e na execução dos contratos. Mas Whittaker e Zimmerman asseveram que essa generalização a respeito da irrelevância da boa-fé no direito inglês é um tanto caricaturesca, advertindo que tais descrições não correspondem precisamente à concepção da boa-fé no direito contratual inglês ao longo da história. ${ }^{344}$ Referem os autores que o direito inglês aceitou a noção ampla de boa-fé e a proteção da confiança em relação às expectativas dos comerciantes, na vigência da lex mercatoria, cujos ditames, baseados nos usos e costumes do comércio, foram assimilados pelo direito contratual, que também foi influenciado pela noção canônica de boa-fé, e por preceitos do Civil Law. Durante o período que Atayiah classificou como de declínio da liberdade contratual (1870 - 1980), ${ }^{345}$ o direito inglês enfatizou os deveres pré-contratuais e acolheu teorias derivadas do princípio da boa-fé.

\footnotetext{
${ }^{342}$ ZIMMERMAN, Reinhard; WHITTAKER, Simon (Eds.). op. cit., p. 38.

${ }^{343}$ Martin Walford v. Charles Miles [1992]. A.D.R.L.R. p. 01/23.

${ }^{344}$ ZIMMERMAN, Reinhard; WHITTAKER, Simon (Eds.). op. cit., p. 41.

${ }^{345}$ ATIYAH, Patrick S. An introduction to the law of contract. $5^{\text {th }}$ ed. Oxford: Oxford University Press, 1995. p.15.
} 
A famosa decisão de Lord Mansfield no caso Carter v. Boehm, que reconheceu o contrato de seguro como uberrimae fidei, foi apontada por Whittaker e Zimmerman como reflexão de um elemento então presente nas fontes do direito comercial inglês, embora tenha sido proferida nesse específico contexto. ${ }^{346}$

Para ilustrar seu argumento de que a postura liberal do direito inglês moderno não representa um desenvolvimento contínuo da sua sequência histórica, Zimmerman e Whittaker asseveram que, no início do século XIX, a má-fé na formação do contrato era fundamento para sua anulação. Invocam um caso de compra-e-venda em que um dos contratantes incorrera em omissão dolosa, e mencionam outros casos de anulação baseada em manifesto desequilíbrio da base do negócio. ${ }^{347}$ Conquanto esta aplicação incipiente e fragmentada do princípio da boa-fé possa não ser suficiente para demonstrar que os tribunais ingleses recorreram regularmente ao princípio para contornar eventuais desequilíbrios contratuais, não se pode negar que realmente "não há diferença significativa entre exigência objetiva de boa fé e proteção das expectativas justificadas das partes".348 $\mathrm{Na}$ verdade, a diferença estaria na interpretação dada à boa-fé pelos ingleses: a obrigatoriedade dos contratos resumida na máxima pacta sunt servanda sempre foi o princípio mais prestigiado no direito inglês e a proteção da justificável confiança dos contratantes não contraria esta regra, mas a enfatiza.

A intervenção judicial na autonomia privada é mínima e só quando justificada por circunstâncias excepcionais. Assim, os contratos de regime especial comportam aplicações do princípio da boa-fé, como as relações de emprego, parceria, fiança, e seguro, e todos os contratos que envolvem deveres fiduciários inerentes à relação principal-agent, pela qual uma das partes está adstrita a zelar pelos interesses da outra, inclusive em detrimento dos seus próprios. Foi o direito inglês que sublinhou as peculiaridades do contrato de seguro,

\footnotetext{
${ }^{346}$ ZIMMERMAN, Reinhard; WHITTAKER, Simon (Eds.). op. cit., p. 42. Analisaremos os reflexos dessa decisão ao tratarmos da informação no contrato de seguro.

${ }^{347}$ Id. Ibid., p. 42-44. Os autores citam o trabalho pioneiro de Joseph Chitty, A Treatise of Commercial Law, publicado em 1824.

${ }^{348}$ A expressão é de Lord Steyn, em Contract law: fulfilling the reasonable expectations of honest men. Law Quarterly Review, n. 113, p. 433-439, 1997, que sustenta a operacionalidade da noção de boa-fé, mas a considera desnecessária, diante da postura usual dos tribunais ingleses. "As long as our courts always respect the reasonable expectations of parties our contract law can be left to develop in accordance with its own pragmatic traditions. And where in specific contexts duties of good faith are imposed on parties our legal system can readily accommodate such a well tried notion. After all, there is not a world of difference between the objective requirement of good faith and the reasonable expectations of parties." (grifo nosso).
} 
classificando-o como uberrimae fidei, salientando a importância da informação nesta relação em que a inerente assimetria informacional pode tornar-se extremamente nociva. ${ }^{349}$

Em consonância com a relevância atribuída pelo direito inglês à autonomia privada e à força vinculante dos contratos, ressalvadas as exceções, a regra básica da informação (caveat emptor) é seguida mais estritamente do que no direito continental, como evidencia o caso do desenho de Degas, discutido por Zimmerman e Whittaker. ${ }^{350}$ No seu estudo comparativo, eles analisaram o caso de um professor de física aposentado que pede a uma negociante de obras de arte que verifique se, na casa dele, havia algo de valor para venda. Deparando com um desenho de Degas, a negociante perguntou ao proprietário quanto ele achava que valia, ao que ele respondeu não ter a mínima ideia do valor. A marchand pagou 1,200 libras pela obra, vendendo-a, depois, por 85,000 libras. Perante o direito alemão, o negócio jurídico comportaria anulação com base no $§ 138$, II, BGB,${ }^{351}$ ou indenização com fundamento na culpa in contrahendo.

Os autores comparam as soluções dos diferentes sistemas jurídicos estudados em relação a este caso por eles examinado. E concluem que todos, menos o inglês e o irlandês, permitem a anulação do contrato em favor do vendedor. Na França, Espanha, Itália, Bélgica e Alemanha, o contrato poderia ser anulado com fundamento na omissão dolosa da compradora. No direito escocês, em face das peculiares circunstâncias do caso, também caberia anulação, mas por influência indevida, e não com base em omissão dolosa. No direito belga e no holandês, o foco se deslocaria da conduta da compradora, para o erro do vendedor, assim como no inglês, com a ressalva de que, neste, a solução não seria favorável ao vendedor mal informado. A legislação austríaca daria ensejo à subsunção do fato ao instituto lesão enorme, como ocorreria no sistema suíço, mas não com base na lei, e sim, na criação doutrinária e jurisprudencial desenvolvida a partir do princípio da boa-fé. Eventualmente, poderia caber indenização por danos com base na culpa in contrahendo, seja invocando normas de responsabilidade contratual, como na Alemanha, seja com base na responsabilidade aquiliana, como na França. ${ }^{352}$ Este quadro comparativo do tratamento

\footnotetext{
${ }^{349}$ Detalharemos esta questão com a abordagem específica da informação no contexto dos seguros privados.

${ }^{350}$ ZIMMERMAN, Reinhard; WHITTAKER, Simon (Eds.). op. cit., Case 2: Degas Drawing. p. 208-235.

${ }^{351} \$ 138$. Legal transaction contrary to public policy; usury.

(1) A legal transaction which is contrary to public policy is void.

(2) In particular, a legal transaction is void by which a person, by exploiting the predicament, inexperience, lack of sound judgement or considerable weakness of will of another, causes himself or a third party, in exchange for an act of performance, to be promised or granted pecuniary advantages which are clearly disproportionate to the performance.

${ }^{352}$ ZIMMERMAN, Reinhard; WHITTAKER, Simon (Eds.). op. cit., p. 233-235.
} 
do dever de informação nos diversos países, deixa entrever um pouco da ideologia políticofilosófica subjacente à cultura jurídica de cada povo.

No direito brasileiro, o caso discutido poderia caracterizar erro, pois preenche os requisitos legais para tanto (art.138 CC): a disparidade do preço em relação ao efetivo valor da obra é elemento substancial do negócio jurídico e seria facilmente percebido pela especialista (compradora). Tratando-se de erro substancial e reconhecível, o contrato comportaria, em tese, anulação, se proposta dentro do prazo decadencial (art. 178, II, CC). Pode-se, alternativamente, cogitar de pretensão indenizatória com base em responsabilidade pré-contratual por afronta ao padrão de boa-fé insculpido no art. 422, do Código Civil.

Mas o caso analisado comporta reflexão. Ressalvada a caracterização do erro, cujos requisitos, embora permitam alguma apreciação valorativa, são mais objetivos, ${ }^{353}$ a responsabilização por omissão dolosa com base em violação do princípio de boa-fé, só é admissível devido às peculiares características do caso. Ao que indica a narrativa, estaria implícito naquele contexto que a avaliação de eventuais bens de valor teria sido confiada à especialista. Tendo sido a negociante de arte instada pelo professor a avaliar bens para venda, a avaliação seria uma obrigação instrumental do contrato, a qual exige especial confiança entre as partes, pois a avaliação de bens implica o dever de informar a verdade. Examinado dessa perspectiva, a marchande teria a obrigação contratual de informar à contraparte o valor da peça de arte, a nosso ver, não porque fosse especialista, mas porque a avaliação lhe fora confiada e era parte do negócio jurídico.

Porém, não fossem as nuances peculiares do caso, ou seja, se não estivesse implícita a obrigação de avaliar, não caberia a imposição do dever de informar. Primeiro, porque a cada um incumbe conhecer os próprios bens, o que implica na identificação de sua qualidade e valor, e, segundo, porque especialidade tem preço, e deve render ganhos ao especialista, que não estaria adstrito a renunciá-los em benefício do vendedor que desconhece o valor de seus próprios bens. ${ }^{354}$ Isto retrata o movimento natural da economia,

\footnotetext{
${ }^{353} \mathrm{~A}$ essencialidade do erro do vendedor, no caso, seria incontestável, porque concerne à essência do objeto da venda, que não é um desenho qualquer, mas uma obra de arte; e a recognoscibilidade também é evidente, pois a compradora é uma especialista, e não lhe poderia ter passado despercebida a qualidade do objeto da compra.

${ }^{354}$ Como seria o caso do antiquário que viaja pelo interior do país, e encontra verdadeiras relíquias sacras desprezadas pelos proprietários, que as vendem como coisas velhas e não antiguidades, seja por desconhecimento de seu valor, seja pelo avanço da catequese evangélica. Este movimento natural da economia faz com que a propriedade dos bens se transfira de quem os valoriza menos para quem os valoriza mais. Isto deve ser incentivado desde que não premie a má-fé retratada no conhecido ardil de
} 
em que a propriedade dos bens se transfere de quem os valoriza menos para quem os valoriza mais, e reflete o substrato liberal dos direitos inglês e irlandês, independentemente das circunstâncias do caso.

Entretanto, seja por influência de Civil Law, seja pela crescente convergência dos dois sistemas jurídicos a partir da década de sessenta, instituíram-se medidas protetivas, como o Misrepresentation Act, de 1967, que trata das distorções da informação nos contratos, o controle legal dos contratos-padrão (Unfair Contract Terms Act) e das relações de consumo (The Unfair Terms in Consumer Contracts Regulations). ${ }^{355}$ Estas são consideradas aplicações do princípio da boa-fé, mas protegem a confiança do destinatário da declaração, o que sempre esteve no foco de atuação do direito inglês, e seus pressupostos são a disparidade de informação e/ou de poder de barganha, o que justificaria, em tese, o controle.

A entrada do Reino Unido na União Europeia, a instituição das diretivas no âmbito das relações jurídicas e o avanço dos estudos para criação de um direito contratual europeu, tendem a aproximar mais Common e Civil Law. Portanto, ainda que os juristas britânicos não considerem o dever geral de boa-fé necessário ou desejável, o princípio vem sendo imposto ao direito inglês, embora por uma fresta da porta de entrada, devido à implementação das diretivas europeias, compelindo-o a acomodar o conceito. ${ }^{356}$

O descumprimento do dever de informação pode acarretar rescisão do contrato e indenização por perdas e danos nos casos específicos em que se exige adstrição de uma parte à boa-fé e aos interesses da contraparte. Excluídas as exceções apontadas, os casos de erro ou simples omissão de informação não recebem proteção jurídica.

Em matéria de responsabilidade civil também não existe um princípio geral que prescreva o dever de informar, como não há regra alguma sobre vícios pré-contratuais. Eventual pretensão de reparação de danos por falhas de informação não pode ser fundada

\footnotetext{
corretores de imóveis oportunistas, que, instados a avaliar imóveis contra pagamento do serviço pelo cliente, ou para intermediar a venda do bem, apresentam avaliações muito inferiores ao valor de mercado do imóvel, e, em seguida, apresentam uma interposta pessoa para comprá-lo. São, pois, casos só aparentemente iguais.

${ }^{355}$ Logo depois da promulgação do UCTA em 1977, foi disciplinada a informação nos contratos de compra-evenda por meio do Sale of Goods Act, de 1979. A criação dos controles especificamente incidentes sobre diversos tipos de contratos, que foram destacados pela legislação especial, provocou certa fragmentação do direito contratual, segundo BEATSON, Jack; FRIEDMANN, Daniel. Introduction: from 'classical' to modern contract law. In: BEATSON, Jack; FRIEDMANN, Daniel (Eds.). Good faith and fault in contract law. 1995, rep. 2002. Oxford: Claredon Press, 2002. p. 16.

${ }^{356}$ TETLEY, William. Good faith in contract - particularly in the contracts of arbitration and chartering. Journal of Maritime Law and Commerce, v. 35, n. 3, p. 561-616, 2004.
} 
em boa-fé, mas em negligência, e a responsabilidade só poderá ser imposta ao negligente, se justificada a confiança da contraparte. ${ }^{357}$

\section{Direito Privado Europeu}

A União Europeia, formalmente instituída em 1993 (tratado de Maastricht), opera segundo a competência conferida pelos países-membros. ${ }^{358}$ A implementação desse projeto de unificação incluiu a criação de normas comuns aos países signatários, de modo a permitir a harmonização legislativa em nível comunitário, visando a facilitar o comércio, aumentar o fluxo de investimentos e garantir a segurança jurídica das relações entre os membros.

\section{Princípios de Direito Europeu dos Contratos}

A uniformização tem sido objeto de estudos da Comissão de Direito Contratual Europeu (Comissão Lando), que editou os Princípios de Direito Contratual Europeu (PECL), cujo objetivo é formular a base comum do regime jurídico europeu dos contratos. Esses princípios guardam muita semelhança com os emanados do Instituto International para a Unificação do Direito Privado (UNIDROIT), organização intergovernamental independente encarregada de coordenar os estudos de harmonização e uniformização do direito contratual internacional.

Conquanto não tenham eficácia vinculante, já que sua aplicação depende ou da convenção entre partes, ou de não ter sido indicado o regime jurídico que disciplina o contrato (art. 1:101 PECL), os Princípios de Direito Contratual Europeu orientam a interpretação dos contratos celebrados no âmbito da União Europeia e sinalizam para a convergência dos diversos regimes jurídicos contratuais dos países filiados.

Dentre os principais temas abordados por esses princípios estão, além da liberdade de contratar e da força vinculante dos contratos, a boa-fé contratual como padrão de conduta dos contratantes, e como cláusula geral para interpretação e integração dos

\footnotetext{
${ }^{357}$ SCHÄFER, Hans-Bernd; OTT, Claus. The economic analysis of civil law, cit., p. 390.

${ }^{358} \mathrm{~A}$ ideia da união surgiu após a segunda guerra mundial, visando à integração dos países europeus de forma a evitar extremismos nacionalistas, cuja experiência tinha sido devastadora para o continente. Assinados tratados que reuniram alguns países em torno de objetivos mais restritos, a ideia de união evoluiu para a formação de um bloco econômico mais consistente unido por políticas comuns e instituições reconhecidas pelos países membros.
} 
contratos, embora os usos e costumes também tenham sido expressamente indicados como fontes do direito contratual.

A boa-fé é invocada em grande parte dos dispositivos, a começar pelos critérios interpretativos e supletivos dos próprios princípios (art. 1:106). ${ }^{359}$ As circunstâncias relevantes que devem ser consideradas na interpretação contratual incluem as exigências da boa-fé (art. 5:102). ${ }^{360} \mathrm{O}$ princípio da boa-fé também serve de critério nos casos de revisão e adaptação do contrato (art. 4:109). Opera também como padrão de comportamento dos contratantes (art. 1:201) ${ }^{361}$, como dever de cooperação (art. 1:202), ${ }^{362}$ e como parâmetro para estabelecer o critério de razoabilidade do artigo $1.302 .^{363}$

No capítulo da formação dos contratos, os princípios prevêem a responsabilidade pelas negociações contrárias à boa-fé no art. 2:301. ${ }^{364} \mathrm{O}$ art. 2:302 responsabiliza o contratante por quebra de confidencialidade, se divulgar informação confidencial ou usá-la em proveito próprio, mesmo que não tenha sido celebrado o contrato. ${ }^{365}$

\footnotetext{
${ }^{359}$ Art. 1:106. Interpretação e complementação.

(1) Estes princípios devem ser interpretados e desenvolvidos de acordo com seus objetivos. Em especial, deve ser focalizada a necessidade de promover a boa-fé e a lealdade nos negócios, a segurança jurídica nas relações contratuais e a uniformidade de sua aplicação.

${ }^{360}$ Art. 5:102: Circunstâncias Relevantes.

$\mathrm{Na}$ interpretação do contrato, deverão ser especialmente levadas em consideração:

(a) as circunstâncias em que foi concluído, inclusive as negociações preliminares;

(b) a conduta das partes, mesmo subsequente à conclusão do contrato;

(c) a natureza e o objetivo do contrato;

(d) a interpretação que já tenha sido dada a cláusulas similares pelas partes e as práticas estabelecidas entre elas;

(e) o significado comumente atribuído aos termos e expressões no ramo de atividade pertinente e a interpretação já dada a cláusulas semelhantes;

(f) usos e costumes; e

(g) boa-fé e lealdade negocial.
}

${ }^{361}$ Art. 1:201. Boa-fé contratual. Cada parte deve atuar de acordo com as exigências da boa-fé e lealdade. As partes não podem excluir nem limitar este dever.

${ }^{362}$ Art. 1:202. Dever de cooperação. Cada parte tem o dever de cooperar com a outra para que o contrato produza integralmente seus efeitos.

${ }^{363}$ Art. 1:302: Razoabilidade.

Segundo estes Princípios, razoabilidade deve ser julgada conforme pessoas de boa-fé e na mesma situação das partes considerariam ser razoável. Deverá ser levada em conta a natureza e o objetivo do contrato, as circunstâncias do caso, e os usos e costumes pertinentes.

${ }^{364}$ Art. 2:301: Negociações Contrárias à Boa-fé.

(1) As partes têm liberdade de negociar e não serão responsabilizadas por não se concluir o contrato.

(2) Entretanto, a parte que contrariar a boa-fé nas negociações ou na sua ruptura, será responsável pelas perdas causadas à outra parte.

(3) É contrário à boa-fé manter negociações ou prosseguir com elas sem intenção de chegar a um acordo com a contraparte.

${ }^{365}$ Art. 2:302: Quebra de confidencialidade. Se informações confidenciais providas, por uma das partes durante as negociações, a contraparte não poderá divulgá-las ou usá-las em seu próprio benefício, seja ou não o contrato concluído. A sanção para a quebra desse dever poderá incluir reparação da perda sofrida pela contraparte e restituição do benefício auferido pela parte. 
Especificamente em relação à informação nos contratos, os PECL abordam o dever de informar no capítulo da validade dos contratos, associado aos vícios de consentimento.

$\mathrm{O}$ art. $4: 103^{366}$ trata do erro essencial de fato ou de direito, exigindo os requisitos de essencialidade e recognoscibilidade, mas excepcionando os casos de erros inescusáveis.

Tratando de informação incorreta, o art. 4:106 ${ }^{367}$ estabelece a responsabilidade do contratante que a prestar à contraparte, ainda que esta não tenha incidido em erro essencial ao celebrar o contrato. Portanto, mesmo que a informação errada não dê causa à anulação do contrato, a parte enganada será protegida com o direito à indenização pelas perdas e danos daí decorrentes.

$\mathrm{O}$ art. $4: 107^{368}$ concerne ao dolo e especialmente à distorção ou omissão de informação, estabelecendo critérios para a exigência do dever de informar e cominando a anulação do contrato. Caso não exerça ou decaia desse direito, a parte enganada poderá exigir indenização pelos danos causados pela conduta dolosa, omissiva ou comissiva, nos termos do art. 4:117. As medidas cabíveis em decorrência de erro ou dolo só poderão ser excluídas ou restringidas por convenção das partes, se tal exclusão ou restrição não for contrária à boa-fé (art. 4:118).

${ }^{366}$ Art. 4:103: Erro Essencial de Fato ou de Direito.

(1) O contratante poderá anular o contrato por erro essencial de fato ou de direito, se:

(a) (i) o erro foi causado por informação fornecida pela parte contrária; ou

(ii) a parte contrária sabia ou deveria saber do erro e deixar a contraparte incidir no erro seria contrário à boa-fé;

(iii) a parte contrária incidiu no mesmo erro, $\mathrm{e}$

(b) a parte sabia ou deveria saber que, se a contraparte soubesse a verdade, não teria celebrado o contrato ou o teria feito em termos fundamentalmente diferentes.

(2) Entretanto, o contratante poderá anular o contrato se:

(a) o erro, naquelas circunstâncias era inescusável, ou

(b) o contratante [que incidiu em erro] assumiu risco do erro ou, nas circunstâncias, deveria ter assumido.

${ }^{367}$ Art. 4:106: Informação Incorreta.

A parte que tiver celebrado o contrato baseando-se em informação incorreta fornecida pela contraparte poderá exigir indenização de acordo com o Art. 4:117(2) e (3), mesmo que a informação não tenha dado causa a erro essencial nos termos do art. 4:103, a menos que a parte que tiver fornecido a informação tenha razão para acreditar que era correta.

${ }^{368}$ Art. 4:107: Dolo.

(1) A parte poderá anular o contrato quando seu consentimento tiver sido induzido por dolo da contraparte, seja por meio de palavras ou atos, ou omissão fraudulenta de informação, cuja divulgação fosse exigida de acordo com a boa-fé e a lealdade.

(2) A conduta da parte ou sua omissão são fraudulentas quando têm o objetivo de enganar.

(3) Para estabelecer se a parte teria a obrigação de fornecer determinada informação, devem-se levar em conta todas as circunstâncias, inclusive:

(a) se a parte tinha conhecimentos técnicos;

(b) o custo da obtenção da informação;

(c) se a outra parte poderia razoavelmente obter a informação por si própria; e

(d) a aparente importância da informação para a outra parte. 
O artigo 6:101 dispõe sobre o efeito vinculante das declarações feitas pela parte antes ou durante a conclusão do contrato, ${ }^{369}$ desestimulando especialmente a propaganda enganosa.

São muitos dispositivos que tratam da boa-fé e da proteção da confiança, inclusive abordando aspectos da teoria da aparência (arts. 3:201 e 3:204), mas os mais relevantes são os já apontados.

\section{Projeto do Código Europeu dos Contratos}

Trata-se de uma construção jurídica resultante da ação conjunta de um grupo de renomados civilistas e comparatistas que, sob os auspícios da Accademia dei Giusprivatisti Europei, e sob coordenação de Giuseppe Gandolfi, objetiva homogeneizar o direito contratual na Europa, como instrumento de integração econômica e jurídica dos Estados europeus. $^{370}$

O Livro I foi concluído em 1999, e as edições subsequentes, de 2002 e 2004, foram acompanhadas de notas de apresentação redigidas pelo coordenador do projeto.

Apesar de contar com a colaboração de juristas ingleses, pouco se nota da influência de Common Law nas disposições do código, que parece impregnado da concepção civilista dos demais países europeus.

Embora muitas disposições do Código tratem da boa-fé em geral, tanto no sentido subjetivo como no objetivo, aqui a análise se restringirá aos dispositivos em que ela se relaciona à informação.

\footnotetext{
${ }^{369}$ Art. 6:101: Declarações que são fontes de obrigação contratual.

(1) A declaração feita por uma parte antes ou durante a conclusão do contrato, deve ser considerada fonte de obrigação contratual, se assim a contraparte razoavelmente tiver entendido, levando em conta:

(a) a aparente importância da declaração;

(b) se a parte fez a declaração no curso do negócio; e

(c) a relativa especialidade técnica das partes.

(2) Se uma das partes for fornecedor profissional, que dá informação sobre a qualidade de produtos e serviços por qualquer meio de propaganda e marketing, antes da conclusão do contrato, a declaração deve ser tratada como fonte de obrigação contratual, a menos que se comprove que a contraparte sabia ou deveria saber que a declaração era incorreta.

(3) A informação e outras promessas apresentadas na propaganda de bens e serviços por fornecedores profissionais ou por pessoa ligada à rede de negócios devem ser tratadas como fonte de obrigação contratual, a menos que se comprove que a contraparte sabia ou deveria saber que a declaração ou a promessa era incorreta.

${ }^{370}$ POSENATO, Naiara. In: POSENATO, Naiara; NALIN, Paulo (Orgs.). Código Europeu dos Contratos Projeto Preliminar - Livro I. Curitiba: Juruá, 2008.
} 
$\mathrm{O}$ art. $7^{\circ}$ estabelece o dever geral de informação nas negociações contratuais, determinando que a parte deve informar à outra todas as circunstâncias fáticas ou jurídicas de que tenha ou deva ter conhecimento, e que permitam à contraparte avaliar o contrato e a conveniência de concluí-lo. ${ }^{371}$ No caso de omissão ou distorção de informação, não tendo sido concluído o contrato, caberá indenização em favor do mal informado; e, se já tiver sido concluído, o descumprimento do dever de informar acarretará a responsabilidade pela restituição da soma recebida ou o pagamento de indenização arbitrada judicialmente, ressalvada a possibilidade de anulação por erro. A menção, no parágrafo $2^{\circ}$, ao comportamento contrário à boa-fé, como se fosse condição para impor a penalidade pela quebra do dever de informar, afigura-se desnecessária, porque este dever é objetivo e a sua caracterização no $\S 1^{\circ}$ seria perfeitamente adequada para enquadrar os casos de falha de informação. A par disso, a inserção desse elemento normativo aberto induz a interpretação, a nosso ver, equivocada de dever legal, que prescindiria da análise da intenção do agente. E, na aplicação da lei, conduta contrária à boa-fé será entendida como conduta de má-fé, ou seja, de intenção maliciosa. Como a prova da intenção é difícil, quando não impossível, e estará a cargo do prejudicado, a quebra do dever legal de informar acabará no limbo das boas intenções.

$\mathrm{O}$ art. 39 determina, em linhas gerais, que, se estiver clara a intenção das partes, a interpretação do contrato deve ser literal e sistemática, levando em conta todo o contexto, desde que o resultado não contrarie a boa-fé e a razoabilidade. ${ }^{372}$

\footnotetext{
${ }^{371}$ Art. 7. Dever de informação.

1. Durante as negociações, cada uma das partes tem o dever de informar a outra sobre todas as circunstâncias de fato ou de direito da quais tem ou deveria ter conhecimento, e que possibilitem à outra avaliar a validade ou a conveniência do contrato.

2. Em caso de omissão de informação ou de declaração falsa ou reticente, se o contrato não tiver sido concluído ou for nulo, a parte que agiu contrariamente à boa-fé é considerada responsável com relação à outra, na medida prevista no art. $6, \S 4^{\circ}$. Se o contrato tiver sido concluído, tem o dever de restituir a soma recebida ou de pagar a indenização considerada pelo juiz conforme à equidade, salvo o direito da outra parte de anular o contrato por erro.

${ }^{372}$ Art. 39. Análise do texto contratual e avaliação dos elementos extrínsecos ao ato.

1. Quando as declarações contratuais revelarem de forma clara e unívoca a intenção dos contratantes, o conteúdo do contrato deverá ser deduzido do seu sentido literal, tendo em consideração o texto contratual no seu complexo e coordenando as diferentes cláusulas umas com as outras.

2. Prevalecerá, sobre o significado comum dos termos utilizados, aquele que os contratantes tiverem expressamente declarado atribuir-lhes ou, na sua falta, a acepção técnica ou presente nos usos comerciais que for conforme à natureza do contrato.

3. Quando o exame do texto contratual suscitar dúvidas não superáveis através da sua avaliação global, que também digam respeito às declarações ou ao comportamento das partes, mesmo posteriores à conclusão do contrato, mas, de certa forma, compatíveis com o texto contratual, este deverá ser interpretado de acordo com a intenção comum dos contratantes, conforme resultar dos elementos extrínsecos referentes às partes.

4. Em todos os casos, a interpretação do contato não deve conduzir a um resultado contrário à boa-fé ou à razoabilidade.
} 
São consideradas implícitas no contrato as cláusulas impostas pelo Código, ou por normas comunitárias ou nacionais, mesmo em substituição às dispostas pelas partes; as que derivam do dever de boa-fé, as tacitamente consentidas pelas partes, com base em relações comerciais anteriores, nas negociações, e nos usos e costumes locais; e as que sejam necessárias para que o contrato produza os efeitos pretendidos (art. 32). ${ }^{373}$

$\mathrm{O}$ art. 75 estende o dever de boa-fé também à execução dos contratos, consagrando o princípio pacta sunt servanda. ${ }^{374}$ Mas, ao tratar da exceptio non adimpleti contractus, segundo a qual uma parte poderá recusar-se a cumprir sua obrigação num contrato sinalagmático, se a contraparte descumprir a dela, o art. 108 ressalva eventual recusa contrária à boa-fé, caracterizando-a como: (i) a que acarreta consequências excessivamente onerosas; ou (ii) que causa a extinção da obrigação do credor quando o inadimplemento, já ocorrido, for insignificante; e (iii) que prejudique um direito fundamental da pessoa. ${ }^{375}$

\footnotetext{
${ }^{373}$ Art. 32. Cláusulas implícitas.
}

1. Além das cláusulas expressas, fazem parte do conteúdo do contrato as cláusulas que:

a) são impostas pelo presente Código ou por normas comunitárias ou nacionais, mesmo em substituição a cláusulas diversas introduzidas pelas partes;

b) derivam do dever de boa-fé;

c) deverm ser consideradas tacitamente concordadas entre as partes com base nas relações comerciais anteriores, nas negociações, nas circunstâncias e nos usos gerais e locais;

d) são consideradas necessárias para que o contrato possa produzir os efeitos perseguidos pelas partes.

2. Salvo as disposições relativas à forma, produzem efeitos entre os contratantes, na medida em que correspondam em algum modo ao texto do contrato, as declarações que cada uma das partes fez à outra durante as negociações ou no momento da conclusão do contrato sobre uma situação ou uma expectativa de fato ou de direito, relativa aos sujeitos, ao conteúdo ou às finalidades do contrato, se tais declarações podem ter determinado o acordo entre as partes; ressalva-se a faculdade de utilizar os recursos previstos nos artigos 151 e 157.

3. Nos contratos internacionais-intercontinentais presume-se, salvo estipulação em contrário, que as partes consideraram implicitamente aplicáveis os usos geralmente observados para os contratos do mesmo tipo e do mesmo setor comercial, dos quais elas tinham ou deveriam ter conhecimento.

${ }^{374}$ Art. 75. Modalidades de execução.

1. Cada uma das partes deve adimplir exatamente e integralmente todas as obrigações derivadas do contrato que lhe couberem, sem que seja necessária uma solicitação de quem tem direito às mesmas. Ao executar as prestações devidas, o devedor deve agir em conformidade com o que foi estabelecido pelas partes, a boa-fé e a diligência exigida pelo caso específico, com base nos acordos, nas circunstâncias e na praxe corrente.

2. Com relação à obrigação executada durante o exercício de uma atividade profissional ou empresarial, o grau de diligência exigido também depende da natureza da prestação devida.

3. Se o contrato prevê uma obrigação de fazer de natureza profissional, a mesma se considera cumprida somente quando o devedor realizar, com a diligência exigida, todos os atos necessários para que o resultado previsto seja obtido, salvo se, com base em um acordo das partes, nas circunstâncias ou nos usos, a mesma se considera cumprida somente quando o resultado final tiver sido plenamente realizado.

4. As despesas de execução e de quitação são a cargo do devedor.

${ }^{375}$ Art. 108. Direito do credor de suspender a execução nos contratos sinalagmáticos.

1. Nos contratos sinalagmáticos, se uma das partes não executar ou não oferecer a execução da própria obrigação, independentemente da gravidade do inadimplemento, o credor tem a faculdade de suspender a própria prestação devida contemporânea ou sucessivamente, a menos que tal recusa de sua parte seja contrária à boa-fé.

2. Considera-se contrária à boa-fé a recusa:

a) que cause à outra parte consequências excessivamente onerosas; 
Pode-se imaginar o efeito deletério dessas exceções na aplicação da lei aos casos concretos.

$\mathrm{O}$ art. 151 trata do erro e do dolo, e prescreve as soluções adequadas a cada caso e suas circunstâncias. ${ }^{376}$ Considera essencial o erro relativo a elemento ou aspecto, jurídico ou econômico, fundamental do contrato, que tenha sido decisivo para o consentimento e que seja reconhecível pela contraparte mediante ordinária diligência. $\mathrm{O}$ dolo abrange, além da declaração enganosa, a omissão ou reticência de um contratante, apta a induzir o outro em equívoco.

É digna de nota a importância que o Código parece atribuir aos elementos ou aspectos econômicos do contrato, como se constata em alguns dos dispositivos analisados, deixando entrever a preocupação dos juristas que o elaboraram com a operação econômica subjacente ao contrato.

b) que cause a extinção da obrigação do credor quando o inadimplemento, que já ocorreu, seja de pouca importância;

c) que prejudique um direito fundamental da pessoa.

${ }^{376}$ Art. 151. Contrato viciado por erro.

1. Erro unilateral torna anulável o contrato se concorrem as seguintes circunstâncias:

a) se for relativo a um elemento ou a um aspecto, econômico ou jurídico, fundamental do contrato e a sua presença teve importância decisiva para o consentimento;

b) se, além disso, for provocado por um declaração enganosa ou pelo comportamento injustificadamente reticente da outra parte, ou se esta última percebeu o erro e a sua importância ou deveria ter percebido mediante normal diligência.

2. Se a declaração enganosa provém de um terceiro, o contrato é anulável, quando o engano era do conhecimento da parte que dele obteve vantagem.

3. Ausentes as circunstâncias previstas no $\S 2^{\circ}$ do presente artigo, o erro que não depende de uma grave negligência da parte vítima permite-lhe anular o contrato somente se o mesmo for privado de interesse para ela e se indenizar a outra parte pelo prejuízo que teve por acreditar na validade e no adimplemento tempestivo do contrato.

4. Se estiverem presentes as circunstâncias previstas no $\S 1^{\circ}$, letra ' $b$ ' do presente artigo, o erro não torna anulável o contrato, mas permite que a parte vítima do mesmo pretenda uma retificação da importância da prestação devida ou a reparação do prejuízo, se:

a) trata-se de um erro de cálculo, a menos que seja de tal gravidade que possa ser considerado decisivo para o consentimento;

b) o erro foi relativo a um elemento secundário ou não foi decisivo para o consentimento, ou seja, se o mesmo contrato teria sido igualmente concluído, mas sob condições diversas.

5. A parte em erro não pode anular o contrato se isto se revelar contrário à boa-fé; se, não obstante a réplica fundada da outra parte, persiste com a própria pretensão, pode ser condenada, consideradas as circunstâncias, a fornecer à outra parte uma indenização justa.

6. As disposições contidas nos parágrafos antecedentes aplicam-se mesmo quando o erro for relativo à declaração ou esta for transmitida de forma inexata à outra parte pela pessoa ou pelo escritório encarregados de fazê-lo

7. $O$ erro comum relativo a circunstâncias decisivas, ainda que não tenham sido expressamente mencionadas, que na convicção das partes acompanharam a conclusão do contrato, ou relativo à impossibilidade objetiva da sua execução, ou ainda à previsão errônea concernente à realização de um acontecimento que reveste uma importância decisiva para a economia do contrato, ainda que não tenha sido expressamente mencionado, torna anulável o contrato por iniciativa de qualquer das partes. 


\section{Direito norte-americano $^{377}$}

Como se trata de país composto por unidades federadas, com autonomia inclusive para escolha do sistema jurisdicional, em relação aos Estados Unidos só é possível analisar o todo mediante a dedução de um mínimo denominador comum, que, no caso, se resume às fontes legais do princípio da boa-fé, por ter sido a principal via de acesso da teoria ao direito norte-americano.

Apesar da adoção do sistema de Common Law, por quase todos os estados,378 o padrão de boa-fé entrou no sistema jurídico norte-americano por via de lei, embora a jurisprudência já reconhecesse o aspecto subjetivo do conceito. Mas como era aplicado somente aos casos de aquisição de boa-fé, acabou levando a interpretações errôneas: uma sustentando que o conceito só se aplicava à compra e venda; e outra, defendendo que o critério de boa-fé era sempre subjetivo. ${ }^{379} \mathrm{Na}$ jurisprudência anterior à vigência do código (Uniform Commercial Code), relatam-se casos esparsos de reconhecimento do dever de boa-fé, mas muito escassos em relação às negociações no âmbito contratual, e não se estabeleceu, entre todos os casos, uma linha de critérios orientadores da imposição de tal dever. ${ }^{380}$

Créditos pelo reconhecimento da teoria da boa-fé nos Estados Unidos são atribuídos, em grande parte, à sua inclusão na legislação. A inserção do padrão de conduta na lei se deveu à influência de Karl Llewellyn, redator do Uniform Commercial Code, que se inspirou na provisão Treu und Glauben do $B G B$, com a qual ele teria muita familiaridade, segundo Farnsworth. ${ }^{381}$

As fontes legais da boa-fé nos Estados Unidos são, além do UCC, o Restatement 2nd of Contracts, e o United Nations Convention on Contracts for the International Sale of Goods.

\section{Uniform Commercial Code Con $^{382}$}

O UCC contém mais de cinquenta menções à boa-fé, inclusive uma definição do instituto, que, a rigor, não o define no sentido próprio, que seria traçar-lhe os limites para orientar

\footnotetext{
${ }^{377}$ Para evitar a artificialidade do qualificativo estadunidense, vale sacrificar a clareza: daí a opção pelo adjetivo norte-americano para identificar os Estados Unidos da América.

${ }^{378} \mathrm{Com}$ exceção da Louisiana, filiada ao sistema codificado (civil law) e cuja legislação é inspirada na francesa, não adotou as normas inscritas no $U C C$, com exceção das seções $2^{\mathrm{a}}$ e $6^{\mathrm{a}}$.

${ }^{379}$ FARNSWORTH, Allan E. Good faith performance and commercial reasonableness under the Uniform Commercial Code. University of Chicago Law Review, n. 30, p. 670, 1962-1963.

${ }^{380}$ SUMMERS, Robert. op. cit., p. 216.

${ }^{381}$ FARNSWORTH, E. Allan. Good faith in contract performance. In: BEATSON, Jack; FRIEDMANN, Daniel (Eds.). Good faith and fault in contract law. 1995, rep. 2002. Oxford: Claredon Press, 2002. p. 154-155.

${ }^{382} \mathrm{O} U C C$ é uma espécie legislativa que disciplinou as principais atividades comerciais nos Estados Unidos, no intuito de harmonizar seu regime, e foi adotada pelos estados da federação.
} 
sua aplicação. A seção $\$ 1-201(20)^{383}$ conceitua boa-fé como honestidade de fato e observância de padrões comerciais razoáveis de negociação leal. Honestidade efetiva e razoabilidade são, pois, os parâmetros pelos quais o código traduz o significado de boa-fé. ${ }^{384}$

As disposições fundamentais são as das seções $\$ 1-304$ e $\$ 1-302(b)$. A primeira ${ }^{385}$ impõe o dever geral de boa-fé aos contratos disciplinados pelo Código, embora não alcance a fase pré-contratual. Entretanto, a quebra desse dever legal não serve como fundamento autônomo de ação judicial, mas seu descumprimento no desempenho de determinada obrigação configura inadimplemento contratual. ${ }^{386}$ A norma da seção $\$ 1-302(b)^{387}$ destaca o aspecto vinculante do padrão prescrito, o qual inclui, além da boa-fé, diligência, razoabilidade e cuidado, e que as partes só podem dispor sobre os critérios pelos quais o

\footnotetext{
${ }^{383}$ \$ 1-201(20)."Good faith," except as otherwise provided in Article 5, means honesty in fact and the observance of reasonable commercial standards of fair dealing. Este artigo resulta da alteração introduzida pela revisão do UCC pelo American Law Institute, cujo comentário oficial aduz: (...) 20. "Good faith." Former Section 1-201(19) defined "good faith" simply as honesty in fact; the definition contained no element of commercial reasonableness. (...) Over time, however, amendments to the Uniform Commercial Code brought the Article 2 merchant concept of good faith (subjective honesty and objective commercial reasonableness) into other Articles.

${ }^{384} \mathrm{E}$ na seção \$1-201(9), define o comprador de boa-fé no curso regular dos negócios: "Buyer in ordinary course of business" means a person that buys goods in good faith, without knowledge that the sale violates the rights of another person in the goods, and in the ordinary course from a person, other than a pawnbroker, in the business of selling goods of that kind. A person buys goods in the ordinary course if the sale to the person comports with the usual or customary practices in the kind of business in which the seller is engaged or with the seller's own usual or customary practices. A person that sells oil, gas, or other minerals at the wellhead or minehead is a person in the business of selling goods of that kind. A buyer in ordinary course of business may buy for cash, by exchange of other property, or on secured or unsecured credit, and may acquire goods or documents of title under a preexisting contract for sale. Only a buyer that takes possession of the goods or has a right to recover the goods from the seller under Article 2 may be a buyer in ordinary course of business. "Buyer in ordinary course of business" does not include a person that acquires goods in a transfer in bulk or as security for or in total or partial satisfaction of a money debt.

${ }^{385}$ \& 1-304. Obligation of Good Faith. Every contract or duty within [the Uniform Commercial Code] imposes an obligation of good faith in its performance and enforcement. Esta seção era a antiga 1-203, renumerada após a revisão do UCC.

${ }^{386}$ Comentário oficial do American Law Institute (1994) à SECTION 1-304 UCC. OBLIGATION OF GOOD FAITH:
}

1. This section sets forth a basic principle running throughout the Uniform Commercial Code. The principle is that in commercial transactions good faith is required in the performance and enforcement of all agreements or duties. While this duty is explicitly stated in some provisions of the Uniform Commercial Code, the applicability of the duty is broader than merely these situations and applies generally, as stated in this section, to the performance or enforcement of every contract or duty within this Act. It is further implemented by Section 1-303 on course of dealing, course of performance, and usage of trade. This section does not support an independent cause of action for failure to perform or enforce in good faith. Rather, this section means that a failure to perform or enforce, in good faith, a specific duty or obligation under the contract, constitutes a breach of that contract or makes unavailable, under the particular circumstances, a remedial right or power. This distinction makes it clear that the doctrine of good faith merely directs a court towards interpreting contracts within the commercial context in which they are created, performed, and enforced, and does not create a separate duty of fairness and reasonableness which can be independently breached.

${ }^{387}$ \& 1-302 (b). Variation by Agreement. (b) The obligations of good faith, diligence, reasonableness, and care prescribed by [the Uniform Commercial Code] may not be disclaimed by agreement. The parties, by agreement, may determine the standards by which the performance of those obligations is to be measured if those standards are not manifestly unreasonable. Whenever [the Uniform Commercial Code] requires an action to be taken within a reasonable time, a time that is not manifestly unreasonable may be fixed by agreement. 
cumprimento das obrigações deve ser medido, desde que observada a razoabilidade. Mas o $U C C$ não adota a boa-fé como princípio orientador da pré-contratação.

A seção $\S 2 a-103(2)^{388}$ estabelece que, em se tratando de comerciante, boa-fé não é só honestidade efetiva, mas também observância dos padrões razoáveis de comércio justo.

\section{Restatement 2nd of Contracts ${ }^{389}$}

A seção $\S 205^{390}$ dispõe que todo contrato impõe às partes o dever de boa-fé e lealdade nas negociações, em sua realização e execução, estendendo, assim, o padrão legal a todos os contratos. ${ }^{391}$ Este dispositivo foi incluído posteriormente, e os comentários refletem a influência de Robert Summers, ${ }^{392}$ que abordou a boa-fé como conceito excludente, de forma que ela fosse mais bem compreendida, considerando que a expressão não tem sentido próprio, mas serve para excluir muitas formas heterogêneas de má-fé. ${ }^{393} \mathrm{O}$ comentário constante do Restatement admite que, sendo impossível catalogar os tipos de má-fé, limita-se a destacar os que têm sido reconhecidos pela doutrina e jurisprudência, dentre os quais aponta a consciente falta de diligência, donde se depreende que a negligência consciente é modalidade de má-fé admitida pelo direito norte-americano. ${ }^{394}$

Apontando a notável versatilidade da doutrina da boa-fé nos Estados Unidos, Summers arrolara uma série aberta de aplicações do conceito, que poderiam servir de fundamento à pretensão de exoneração de obrigação, ou nos casos de abuso de direito,

\footnotetext{
${ }^{388} \S 2$ 2-103. Definitions and Index of Definitions. (...) (b) "Good faith" in the case of a merchant means honesty in fact and the observance of reasonable commercial standards of fair dealing in the trade.

${ }^{389}$ Restatement é uma espécie normativa, elaborada pelo American Law Institute, e cujos artigos traduzem a consolidação do entendimento dos pontos abordados, e trazem comentários a respeito de sua aplicação, cf. Black's Law Dictionary, Brian A. Garner (ed) 9th. ed. West, 2009. O Restatement of Contract data de 1932 e o Restatement $2^{\text {nd }}$, do qual tratamos aqui, foi instituído em 1979 e publicado em 1981. As provisões atinentes à boa-fé foram sendo paulatinamente incorporadas ao código, na medida em que eram desenvolvidas pela jurisprudência.

${ }^{390} \$ 205$. Duty of Good Faith and Fair Dealing. Every contract imposes upon each party a duty of good faith and fair dealing in its performance and its enforcement.

${ }^{391}$ A boa-fé aparece em muitas outras seções do Restatement (Second) of Contracts, como: §§ 34, 74, 157, 172, 176, 188, 228, 241, 248, 251, 257, 259, 264, 265, 277 (1979).

${ }^{392}$ Como expressamente reconheceu Robert Braucher, relator responsável pela inclusão do dispositivo. BRAUCHER, R. Interpretation and legal effect in the second restatement of contracts. Columbia Law Review, n. 81, p. 15, 1981.

${ }^{393}$ SUMMERS, Robert. op. cit., p. 195-267 "It will be argued that good faith, as used in the case law, is best understood as an "excluder" - it is a phrase which has no general meaning or meanings of its own, but which serves to exclude many heterogeneous forms of bad faith. It will also be suggested that if the Code draftsmen had perceived this, they would not have given the term the general, invariant meaning: "honesty in fact in the conduct or transaction concerned." Id. Ibid., p. 196.

${ }^{394} \mathrm{E}$ isso faz sentido porque, tanto na Inglaterra como nos Estados Unidos, a interpretação da boa-fé se resumiria, em última instância, como todo comportamento que frustra o que o outro contratante pode razoavelmente esperar do contrato.
} 
omissão de defeitos do objeto da prestação de venda, abuso do poder de barganha, falta de diligência, entre outras funções. ${ }^{395}$ Acrescenta que os tribunais nem sempre abordaram as variadas formas de má-fé, com base no dever de boa-fé, mas em outros fundamentos, como a honestidade, a cooperação, a violação de obrigações implícitas no contrato. ${ }^{396}$

A conceituação da boa-fé rendeu muitos debates nos Estados Unidos. Com razão, Michael Bridge criticou Summers, apontando a desvantagem de sua abordagem casuística, que equivaleria a afirmar que o dever de boa-fé será considerado violado quando o juiz bem entendesse, o que não soluciona a questão nem fornece guia algum para os casos futuros. $^{397}$

Steven Burton retomou a análise do significado da boa-fé, aduzindo que Summers elaborou lista de condutas de má-fé, mas não estabeleceu critério unificador de tais categorias, que explicasse o que elas têm em comum. Conclui que nem a jurisprudência nem a doutrina tinham formulado padrão operacional apto a distinguir o desempenho contratual de boa-fé e de má-fé. ${ }^{398} \mathrm{Na}$ sua concepção, a boa-fé limita o exercício da discricionariedade conferida a cada parte pelo contrato, e o modelo por ele proposto se baseia nas expectativas das partes. Nos dois artigos que escreveu, no início da década de oitenta, sustentou que a má-fé se caracteriza pelo exercício indevido da discricionariedade pelo contratante que tenta captar oportunidades que não mais estão disponíveis com base no contrato e pela recusa, sem razão legítima, em pagar o custo esperado do cumprimento contratual. $^{399}$

Com propriedade Bridge apontou, entre outras, a deficiência do raciocínio circular em que se lastreia a teoria de Burton, ${ }^{400}$ que também não atribui mais precisão ao

\footnotetext{
${ }^{395}$ SUMMERS, Robert. op. cit., p. 216-217.

${ }^{396}$ Id. Ibid., p. 203.

${ }^{397}$ BRIDGE, Michael. Does anglo-canadian contract law need a doctrine of good faith? Canadian Business Law Journal / Revue Canadienne de Droit des Affaires, n. 9, p. 385-426, 1984 Now, the drawback of such an approach is that it seems tantamount to saying that the good faith duty is breached whenever a judge decides that it has been breached. This hardly advances the cause of intellectual inquiry and it provides absolutely no guide to the disposition of future cases, except to the extent that they may be on all fours with a decided case. (p. 398)

${ }^{398}$ BURTON, Steven J. Breach of contract and the common law duty to perform in good faith. Harvard Law Review, n. 94, p. 369-370, 1980-1981.

${ }^{399}$ Id. Ibid., p. 373. BURTON, Steven J. Good faith performance of a contract within Article 2 of the Uniform Commercial Code. Iowa Law Review, n. 67, p. 11-16, passim, 1981-1982.

${ }^{400}$ The first criticism of the Burton model that suggests itself is that it amounts to little more than the proposition that bad faith is a breach of contract and a breach of contract is bad faith: indeed, the author himself has suggested much the same thing elsewhere. BRIDGE, Michael. op. cit., p. 402.
} 
significado do padrão contratual de boa-fé, no mesmo tom da posterior crítica de Summers. $^{401}$

Pouco depois da edição do $U C C$, Farnsworth vaticinava que talvez fosse demais esperar que um sistema de Common Law raciocinasse por analogia aos princípios gerais de seus estatutos, aguardando ansiosamente por desenvolvimentos do conceito de boa-fé por advogados engenhosos e juízes criativos. ${ }^{402}$ É interessante notar que, mais de três décadas depois, o autor descreve a dificuldade dos juristas norte-americanos em distinguir entre tantos significados atribuídos à boa-fé, espelhando a sua própria perplexidade diante do aspecto negativo da decantada versatilidade do conceito. ${ }^{403}$

Segundo Farnsworth, se o problema dos ingleses é a dificuldade de atribuir algum significado à boa-fé, a dificuldade dos norte-americanos é distinguir entre tantos significados atribuídos ao mesmo significante. O conteúdo do princípio provocou debates, que se arrastaram sem solução. ${ }^{404} \mathrm{O}$ autor reporta o caso de um candidato ao exame $S A T$ para admissão ao ensino superior, que, diante da constatação de ter fraudado o exame, surpreendentemente, ganha a ação judicial, em que pretendia o reconhecimento da elevada nota obtida. ${ }^{405}$ Mostrando que a jurisprudência não consegue aplicar bem o princípio da boa-fé, Farnsworth pondera que os tribunais buscam subsídios nos trabalhos de Burton, Summers e no seu, provavelmente sem atinar com a diferença entre essas diversas concepções, o que não surpreende, porque a boa-fé toma formas tão diferentes e assume tantas funções, que se torna difícil distingui-las no contexto fático. Às vezes, a boa-fé é a base para a limitação da discricionariedade exercida por uma parte, como em Burton, ou o fundamento para sancionar comportamentos que violam padrões básicos de honestidade, como em Summers, e outras, é simplesmente a base de um termo implícito no contrato,

\footnotetext{
${ }^{401}$ SUMMERS, Robert. The general duty of good faith - its recognition and conceptualization. Cornell Law Review, n. 67, p. 831-832, 1982.

${ }^{402}$ FARNSWORTH, Allan E. Good faith performance and commercial reasonableness under the Uniform Commercial Code, cit., p. 679.

${ }^{403}$ FARNSWORTH, E. Allan. Good faith in contract performance, cit., p. 161.

${ }^{404}$ Id. Ibid., p. 161.

${ }^{405}$ Trata-se do caso de um estudante que fez o exame SAT (Scholastic Aptitude Text), usado para avaliar candidatos à admissão nas universidades americanas, e depois de uma nota muito baixa (620 pontos), passou por um curso preparatório e, tentando o exame novamente, obteve nota surpreendentemente alta (1030 pontos). Mas testes de segurança e de caligrafia constataram que os dois exames não teriam sido escritos pela mesma pessoa, razão pela qual o candidato deveria se submeter a outro teste para confirmar a validade do resultado. O estudante entrou em juízo e a decisão judicial, fundada em boa-fé, reconheceu a validade do resultado do segundo teste. Não se sabe exatamente, pelo relato do caso, quais as provas apresentadas por ele em juízo, mas isso parece irrelevante diante do fundamento, transcrito por Farnsworth, de que se atribuiu conduta de má-fé ao ETS (Educational Testing Service), organização que aplicou o teste, que não teria investigado o caso suficientemente, concluindo que o impostor era o próprio candidato, exclusivamente com base na prova da análise caligráfica. Id. Ibid., p. 153-154.
} 
como no seu artigo de 1962, que traz a mais restritiva das três concepções. ${ }^{406}$ O argumento de Farnsworth enfatiza a plurivocidade da boa-fé, que pode servir a soluções até antagônicas, com base no mesmo fundamento. E as conclusões que extrai da experiência com a aplicação do princípio, depois de quatro décadas, evidenciam seu desapontamento. $^{407}$

A exigência de boa-fé não se aplica, com base na legislação norte-americana, às negociações pré-contratuais. ${ }^{408}$ Mas o autor argumenta que as teorias desenvolvidas a partir do Uniform Commercial Code, se bem aplicadas, são suficientes para discipliná-las. ${ }^{409} \mathrm{O}$ autor sustenta que a imposição do dever de boa-fé e a responsabilidade por desistência na fase anterior à conclusão do contrato, deveriam ser regras dispositivas das partes, que poderiam prevê-las expressamente, se quisessem submeter-se a elas. ${ }^{410}$ Acrescenta que os tribunais têm-se afastado da doutrina tradicional e apresentado crescente tendência de aplicar a responsabilidade pré-contratual, cujos fundamentos recorrentes são: enriquecimento indevido resultante de negociações frustradas; distorção da verdade (misrepresentation) na fase antecedente à conclusão do contrato; promessa específica durante as tratativas. ${ }^{411}$

Embora não haja regra impositiva expressa do dever de informar na fase précontratual, existe preocupação com transparência, tanto no meio empresarial, em que é comum convencionar-se o dever de informação, como no processo judicial. Neste, a mentira no depoimento pessoal é punida como perjúrio, as partes são obrigadas à completa transparência (full disclosure) na fase instrutória, em que não só devem indicar as provas pretendidas, mas especificar-lhes exatamente a finalidade, e permitir que as testemunhas sejam examinadas pela contraparte (cross examination).

\footnotetext{
${ }^{406}$ FARNSWORTH, E. Allan. Good faith in contract performance, cit., p. 163. O artigo a que o autor se refere, publicado na Chicago Law Review, consta de nota anterior neste capítulo.

${ }^{407} \mathrm{O}$ autor conclui que (i) a boa-fé tem servido para prover serviços para muitos advogados norte-americanos, que produziram um emaranhado de casos, contribuindo para desnortear o curso da teoria; (ii) a discussão do conteúdo do conceito fez a alegria de acadêmicos, que descobriram um tema de congênita discordância; (iii) criou dificuldades aos tribunais, que se bateram sobre questões correntes. E, referindo-se ao caso do candidato que fraudou o exame do SAT, acrescenta que esta "forneceu fundamento para que um adolescente chamado Brian revogasse a decisão de uma das mais sólidas instituições dos Estados Unidos, a Educational Testing Services." FARNSWORTH, E. Allan. Good faith in contract performance, cit., p. 169. As três conclusões serão explicitadas na conclusão deste capítulo.

${ }^{408}$ SUMMERS, Robert. Conceptualisation of good faith in American contract law: a general account. In: BEATSON, Jack; FRIEDMANN, Daniel (Eds.). Good faith and fault in contract law. 1995, rep. 2002. Oxford: Claredon Press, 2002. p. 134.

${ }^{409}$ FARNSWORTH, E. Allan. Precontractual liability and preliminary agreements: fair dealing and failed negotiations, cit., p. 219.

${ }^{410}$ Id. Ibid., p. 286.

${ }^{411}$ Id. Ibid., p. 221-222.
} 
No mais, o direito à informação é resguardado pelo instituto da misrepresentation, ${ }^{412}$ cujas diretrizes constam do Restatement 2nd. of Contracts, ou pela aplicação das regras de responsabilidade civil (tort). Os dispositivos concernentes à misrepresentation especificam os requisitos para sua caracterização, esclarecendo quando é considerada fraudulenta ( $§ 161)$, e apta a induzir a contraparte em erro, e quando constitui causa indutiva do negócio jurídico (§167). Abrange desde o dolo, que pode ser omissivo ou comissivo (§161), e pode acarretar a anulação do contrato, se preenchidos os requisitos do § 164.

\section{Considerações conclusivas}

A análise comparativa do dever de informar é experiência gratificante porque desvenda o cerne da filosofia subjacente ao direito contratual ${ }^{413}$. Reflete não só a cultura jurídica de um povo, mas a ideologia, os valores morais e culturais gravados em sua trajetória histórica e inscritos nas suas escolhas políticas.

\footnotetext{
${ }^{412}$ \$ 161. When Non-Disclosure Is Equivalent to an Assertion. A person's non-disclosure of a fact known to him is equivalent to an assertion that the fact does not exist in the following cases only:

(a) where he knows that disclosure of the fact is necessary to prevent some previous assertion from being a misrepresentation or from being fraudulent or material.

(b) where he knows that disclosure of the fact would correct a mistake of the other party as to a basic assumption on which that party is making the contract and if non-disclosure of the fact amounts to a failure to act in good faith and in accordance with reasonable standards of fair dealing.

(c) where he knows that disclosure of the fact would correct a mistake of the other party as to the contents or effect of a writing, evidencing or embodying an agreement in whole or in part.

(d) where the other person is entitled to know the fact because of a relation of trust and confidence between them.
}

\$162. When a Misrepresentation Is Fraudulent or Material

(1) A misrepresentation is fraudulent if the maker intends his assertion to induce a party to manifest his assent and the maker

(a) knows or believes that the assertion is not in accord with the facts, or

(b) does not have the confidence that he states or implies in the truth of the assertion, or

(c) knows that he does not have the basis that he states or implies for the assertion.

(2) A misrepresentation is material if it would be likely to induce a reasonable person to manifest his assent, or if the maker knows that it would be likely to induce the recipient to do so.

$\$ 164$. When a Misrepresentation Makes a Contract Voidable

(1) If a party's manifestation of assent is induced by either a fraudulent or a material misrepresentation by the other party upon which the recipient is justified in relying, the contract is voidable by the recipient.

(2) If a party's manifestation of assent is induced by either a fraudulent or a material misrepresentation by one who is not a party to the transaction upon which the recipient is justified in relying, the contract is voidable by the recipient, unless the other party to the transaction in good faith and without reason to know of the misrepresentation either gives value or relies materially on the transaction.

\section{$\$ 167$. When a Misrepresentation Is an Inducing Cause}

A misrepresentation induces a party's manifestation of assent if it substantially contributes to his decision to manifest his assent.

${ }^{413}$ Como afirmaram KESSLER e FINE: "an investigation of the scope of the 'duty to disclosure' on a comparative basis is most rewarding; it leads us straight to the heart of the philosophy underlying the law of contracts." KESSLER, Friedrich; FINE, Edith. Culpa in contrahendo, bargaining in good faith, and freedom of contract: a comparative study. Harvard Law Review, cit., p. 438. 
O direito privado adquire gradativamente na Europa, caráter genuinamente europeu, apontando o movimento irreversível de uniformização das legislações dos paísesmembros, o que recomenda a análise dos fundamentos comuns e das discrepâncias entre seus sistemas jurídicos nacionais, e sinaliza a tendência à internacionalização do direito privado, consolidando uma lex mercatoria contemporânea. ${ }^{414}$

Como reconhecem Zimmerman e Whittaker, os juristas ingleses preferem normas de menor abrangência às de amplo espectro, como a boa-fé. Mas os sistemas jurídicos de Common Law que não acolhem esse princípio, têm outros instrumentos para lidar com as situações fáticas que ensejam a aplicação da boa-fé pelos sistemas de Civil Law. ${ }^{415}$

Como a adoção do padrão de boa-fé, entre os sistemas que a acolhem, não implica concordância em relação a seu conteúdo e aos requisitos para sua aplicação, o reconhecimento desse princípio não indica determinada solução a uma dada situação fática, mas apenas permite a possibilidade de tal solução, deixando ao tribunal a escolha de deduzi-la ou não. Diante dessa constatação, Zimmerman e Whittaker concluem que o conceito de boa-fé não provocaria mudança substancial no direito inglês ou escocês, porque cada sistema jurídico pode definir o conteúdo do princípio, não permitindo prever, com base nele, um determinado resultado jurídico. ${ }^{416}$ Isso leva os autores a questionarem o propósito de um princípio destituído de poder ou autoridade ${ }^{417}$, e a conveniência de sua adoção, se não for para trazer alguma mudança para o sistema jurídico, e ainda instigar o juiz a instilar seus valores subjetivos na decisão.

Mas Zimmerman e Whittaker ponderam, afinal, que não se pode negar a influência corretiva de conceitos como a boa-fé, a razoabilidade, a lealdade e a equidade no direito contratual. $^{418}$

Hesselink comenta, em artigo recente, que a boa-fé é considerada princípio, regra, máxima, dever, padrão de conduta, cláusula geral, o que deve parecer confuso demais

\footnotetext{
${ }^{414}$ ZIMMERMAN, Reinhard; WHITTAKER, Simon (Eds.). op. cit., p. 8-11.

${ }^{415}$ Id. Ibid., p. 687.

${ }^{416}$ Id. Ibid., p. 687-688.

${ }^{417}$ Os autores usam a enfática metáfora toothless principle. Id. Ibid., p. 688.

${ }^{418}$ Invocando a concepção aristotélica de equidade, traduzida pelos autores como o recurso que permite escapar à incidência da lei nas circunstâncias em que até o legislador sustentaria sua inobservância, concluem com a advertência de Baldo de que a boa-fé é mais exigida daqueles que mais comerciam. Id. Ibid., p. 701 e p. 108.
} 
para juristas ingleses. ${ }^{419}$ A impropriedade da boa-fé como conceito juridicamente útil, que, além de carregar tantos significados para um só significante, ainda exerce tantas funções concomitantes, representa, na verdade, confusão demais para qualquer jurista e isso se reflete na aplicação da lei. ${ }^{420}$ Complementando a conclusão de Hesselink, a boa-fé não é um conceito juridicamente adequado, porque, não tendo conteúdo minimamente determinável e servindo simultaneamente a tantas funções, incitará a criatividade dos juízes, e criatividade não é qualidade, mas defeito, quando se trata de aplicar o direito.

Porém, há quem sustente a conveniência e a utilidade da adoção do princípio de boa-fé no direito inglês, e do seu desenvolvimento, para que se cristalize num conjunto normativo suficientemente sólido para ser certo, e flexível bastante para ser justo, embora admita que seu reconhecimento acarretará incerteza jurídica. ${ }^{421}$ Vanessa Sims tem razão ao asseverar que, cedo ou tarde, os ingleses terão que acolher o princípio, consagrado na uniformização do direito contratual europeu. Mas, aqui vale a ressalva de Zimmermann e Whittaker ${ }^{422}$ no sentido de que a falta de conteúdo próprio subtrai a autoridade e a eficácia do princípio, porque pode ser preenchido de acordo com a percepção de quem o aplica, nada acrescentando ao sistema jurídico que o adota. ${ }^{423} \mathrm{~A}$ autora argumenta que as tentativas de definir o conceito de boa-fé falham, porque focalizam as aplicações em vez do conceito, ${ }^{424}$ e constroi metáfora interessante de círculos concêntricos para simbolizar a concepção abrangente e multidimensional de boa-fé. Explica que no ponto central está o cerne da boa-fé, a honestidade, que seria o requisito mínimo dos contratos. E, a partir deste ponto, se irradiam outros círculos centrífugos, significando padrões gradativamente mais exigentes de boa-fé. Assim, quanto mais distantes do cerne honestidade, mais honestidade requerem. $^{425}$ Isso parece desafiar a física e a lógica, porque círculos concêntricos em movimento centrífugo conteriam cada vez menos da força ou da substância do núcleo, pois

\footnotetext{
${ }^{419}$ HESSELINK, Martijn W. The concept of good faith. In: HARTKAMP, Arthur S.; HESSELINK, Martijn W. et al (Eds.). Towards a European Civil Code. $4^{\text {th }}$ ed. rev. expan. Alphen aan de Rijn: Kluwer Law International, 2010. p. 619-649.

${ }^{420} \mathrm{E}$ Hesselink conclui que "Good faith is not the highest norm of contract law or even of private law, but no norm at all, and is merely the mouthpiece through which new rules speak, or the cradle where new rules are born. What the judge really does when he applies to good faith is to create new rules.” Id. Ibid., p. 365.

${ }^{421}$ SIMS, Vanessa. Good faith in English contract law: of triggers and concentric circles. Ankara Law Review, v. 1, n. 2, p. 232, 2004.

${ }^{422} \mathrm{~V}$. notas $416-417$.

${ }^{423}$ Tanto isso é verdade que, nestes anos todos em que ele vem sendo aplicado na Alemanha, Itália, Espanha, Peru, Argentina, e Brasil, não consta que estes países tenham moralizado mais o direito contratual e os costumes negociais do que na Inglaterra.

${ }^{424}$ SIMS, Vanessa. op. cit., p. 216. Porém, partir da função para chegar ao conceito tem sido o caminho mais indicado pela metodologia jurídica.

${ }^{425}$ Id. Ibid., p. 213-232.
} 
o efeito do impacto centrifugador diminui à medida que se irradia para fora. Mas a afirmação de que os círculos concêntricos exigem mais boa-fé, à medida que se afastam dela, terá sentido se considerarmos que, quanto mais impessoais e distantes se tornam as relações, menos se submetem às normas sociais, típicas das relações mais próximas e pessoais, exigindo, assim, a imposição de padrão mais exigente de boa-fé para garantir a confiança recíproca. ${ }^{426} \mathrm{E}$ os critérios para determinar a que círculo um contrato pertence podem ser sua natureza e o status das partes, entre outros que a autora denomina gatilhos (triggers), numa referência aos elementos detonadores da força centrífuga dos círculos concêntricos, cujo acionamento aumentaria o grau de boa-fé contratual. ${ }^{427}$ Para identificar esses gatilhos, a autora aponta dois traços comuns subjacentes às hipóteses de proteção legal: desigualdade de poder de barganha e disparidade de informação, reiterando opiniões defendidas pela análise econômica do direito. Mas, alterando o foco de sua análise, acrescenta um terceiro traço comum, que seria o envolvimento pessoal da parte, como o empregado cujo emprego representa, além da renda, a dignidade e a satisfação pessoal, o que exigiria maior proteção contra a má-fé do empregador. ${ }^{428}$

Especificamente em relação ao dever de informar, o estudo coordenado por SeftonGreen, que, como Zimmermann e Whittaker, também parte indutivamente do exame de casos para verificar sua repercussão nos diversos sistemas jurídicos estudados, apresenta algumas conclusões que merecem destaque pela abrangência da análise e variedade das perspectivas nela envolvidas. Exceto os direitos inglês, escocês e irlandês, em que a imposição do dever de informar é excepcional, os demais sistemas jurídicos têm acompanhado a tendência da uniformização normativa europeia de exigir a divulgação de informação, tanto antes como depois da conclusão do contrato, generalizando o que, à luz da doutrina tradicional, era exceção. ${ }^{429} \mathrm{O}$ dever de informar exerce função protetiva e preventiva, e sua crescente exigência resultaria, dentre outras causas, da padronização dos contratos, como forma de assegurar que o conteúdo mínimo contratual seria de conhecimento de ambas as partes. ${ }^{430}$ Sefton-Green assevera que o status das partes não é requisito para a imposição do dever de informar. ${ }^{431}$ Pondera que a exigência de divulgação de informação entre contratantes implica o reconhecimento de que eles são desiguais, e a

\footnotetext{
${ }^{426}$ Esta interpretação emprestada da teoria da confiança de Luhman (v. nota 252) não é, entretanto, denotada ou conotada pelo texto ou contexto.

${ }^{427}$ SIMS, Vanessa. op. cit., p. 230.

${ }^{428}$ Id. Ibid., p. 231.

${ }^{429}$ SEFTON-GREEN, Ruth (Ed.). op. cit., p. 394-395.

${ }^{430}$ Id. Ibid., p. 387-388.

${ }^{431}$ Id. Ibid., p. 389.
} 
tentativa de aparar tal desigualdade é engendrada por duas ordens de razões: a moral e a econômica. A primeira concerne à justiça contratual que estabelece padrão mais elevado de comportamento entre os contratantes, e o dever de informar funcionaria como seu instrumento. ${ }^{432} \mathrm{O}$ argumento econômico se concentra não no comportamento ideal das partes, mas em como alocar, com mais eficiência, a assimetria informacional no mercado. $^{433}$

Kötz também faz análise comparativa dos deveres pré-contratuais de informação, buscando estabelecer denominadores comuns aos regimes jurídicos estudados. ${ }^{434}$ Conclui que é fundamento comum aos sistemas analisados que, se uma parte induz a outra a contratar mediante falsa declaração, ciente da falsidade ou por negligência ou indiferença, a contraparte poderá anular o contrato sob tal fundamento. ${ }^{435} \mathrm{O}$ simples silêncio sobre fatos que a parte sabe ou deveria saber serem importantes em relação à contratação, também é fundamento para anulação, desde que o agente mais informado tivesse o dever de informar a contraparte, ${ }^{436}$ e os códigos dos sistemas analisados não fornecem resposta ou orientação prestável do ponto de vista operacional. ${ }^{437}$

As conclusões de Farnsworth sobre a experiência com a aplicação do princípio, cujo reconhecimento promovera décadas antes, deixam entrever que sua adoção não contribuiu, como alguns acadêmicos propunham, para a consecução do objetivo precípuo do Uniform Commercial Code, que era harmonizar a jurisprudência atinente aos contratos. Isso induz a outra conclusão: eficiente o princípio da boa-fé não é.

No Brasil, a 'eticidade' e a socialidade, como indica Miguel Reale, são os princípios que presidiram a elaboração do novo Código Civil, e o distinguem do individualismo que caracterizava o anterior, inspirando a instituição do padrão de boa-fé e probidade nos contratos, a imposição dos limites da função social, e instituindo normas

\footnotetext{
${ }^{432}$ SEFTON-GREEN, Ruth (Ed.). op. cit., p. 392-393.

${ }^{433}$ Id. Ibid., p. 393-394. A autora comenta as contribuições da análise econômica do direito, mencionando os trabalhos de Kronman, Posner, Cooter e Ulen, e de Fabre-Magnan, que serão discutidos no próximo capítulo.

${ }^{434}$ KÖTZ, Hein. op. cit., p. 5-19.

${ }^{435}$ Id. Ibid., p. 7.

${ }^{436}$ Id., loc. cit. Como vimos, no direito inglês uma parte pode assistir, impunemente, a outra errar, desde que esta erre sozinha, sem o seu auxílio. E o silêncio, por si só, não pode ser considerado fundamento da anulação. O dever de informar só é a regra nos contratos uberrimae fidei, como o de seguro, e nas relações fiduciárias.

${ }^{437}$ Id., loc. cit. Aqui o autor faz um raciocínio circular, pois se o silêncio é fundamento para anulação se o agente mais informado tiver o dever de informar, volta-se à questão inicial que é saber quando incide o dever de informar. Mas, ao longo do texto, Kötz desenvolve os critérios para imposição do dever précontratual de informação, endossando os parâmetros dos analistas de Law \& Economics, cujas contribuições serão examinadas no capítulo subsequente.
} 
abertas para liberar a "imaginação criadora de advogados e juristas e a prudente e não menos instituidora, sentença dos juízes." ${ }^{438} \mathrm{O}$ mentor do Código Civil afirma que "a boa-fé não constitui um imperativo ético abstrato, mas sim uma norma que condiciona e legitima toda a experiência jurídica, desde a interpretação dos mandamentos legais e das cláusulas contratuais até suas últimas consequências." A despeito do reconhecido brilho que o consagrou, a interpretação de Reale não comporta comentários suplementares por não acrescentar nenhum dado novo aos já analisados em relação à adoção da boa-fé como padrão de conduta e cláusula geral.

No seu minucioso estudo, Judith Martins-Costa examinou as formas de atuação da boa-fé no processo obrigacional, e sua repercussão no sistema de direito privado. ${ }^{439}$ Aponta a interação entre a boa-fé e o sistema, ${ }^{440} \mathrm{e}$, descrevendo a trajetória histórica de ambos no âmbito jurídico, constata que "a experiência do direito comparado demonstra que a boa-fé objetiva provoca substanciais alterações no sistema, porque modifica a compreensão e a extensão das fontes de produção de direitos subjetivos e de deveres," flexibilizando ou afastando o princípio da autonomia privada. ${ }^{441}$ Assevera que a codificação do direito privado $^{442}$ e a adoção de preceitos abertos como a cláusula geral de boa-fé promoverá a segurança jurídica, afetada pela confluência de leis especiais e pela aplicação de princípios gerais inexpressos, que podem conduzir à assistematização do direito privado. ${ }^{443}$

Conquanto os preceitos abertos realmente sirvam à necessária flexibilização do sistema jurídico, esse reconhecimento não contraria os argumentos lançados neste e no capítulo anterior em relação às dificuldades e às consequências da aplicação da boa-fé.

Quanto à experiência do direito comparado, as conclusões de Martins-Costa não refletem as opiniões de comparatistas renomados como Zimmerman e Whittaker, Hessler e Fine, Kötz, Sefton-Green, que discutindo a mesma matéria, no mesmo contexto (o direito privado codificado), extraem conclusões diametralmente opostas às de Martins-Costa. A autora ressalva a discordância de Menezes Cordeiro em relação à assertiva de que "as cláusulas gerais não contêm delegação de discricionariedade, por remeterem para

\footnotetext{
${ }^{438}$ REALE, Miguel. Espírito da nova Lei Civil. Miguel Reale, 04 jan. 2003. Disponível em: $<w w w . m i g u e l r e a l e . c o m . b r>$ e Boa-fé no Código Civil. Miguel Reale, 16 ago. 2003. Disponível em: $<$ www.miguelreale.com.br>.

${ }^{439}$ MARTINS-COSTA, Judith. op. cit.

${ }^{440}$ Id. Ibid., p. 27-30 passim.

${ }^{441}$ Id. Ibid., p. 517.

${ }^{442} \mathrm{~A}$ autora explica o processo de codificação do direito privado e a transição da concepção de um sistema jurídico fechado e auto-suficiente para o reconhecimento da necessidade de abertura do sistema. Id. Ibid., p.268-270.

${ }^{443}$ Id. Ibid., p. $517-518$.
} 
valorações objetivamente válidas na ambiência social". Destaca que o jurista português aponta a larga margem de discricionariedade que a boa-fé atribui ao intérprete-aplicador, que redundaria num "verdadeiro arbítrio". 444

A dissidência diante dessa questão seria ainda mais evidente, se comparada com as constatações dos autores de Common Law, especialmente os ingleses. ${ }^{445}$ Isso tudo, sem falar nas conclusões dos adeptos da análise econômica do direito, cujas contribuições serão discutidas no próximo capítulo, mas que, em geral, não reconhecem todas as decantadas qualidades do padrão de boa-fé.

Afirmando que boa-fé significa agir corretamente, ou seja, impor o bom andamento das relações jurídicas mediante a inserção de deveres de informar e cooperar, que seriam as mais perfeitas expressões de lealdade, Tomasevicius pondera que "pensar em deveres de informar e cooperar dispensa qualquer invocação de conceitos morais para dar significado ao princípio de boa-fé. Estes conceitos morais, que se propõem a resolver todos os problemas jurídicos, são meros topoi, próprios para argumentações retóricas." 446 Não parece exagero concluir que essa observação traduz a inutilidade e a desnecessidade da boa-fé objetiva.

A antinomia das interpretações doutrinárias e jurisprudenciais da boa-fé é a prova mais eloquente da insuperável plurivocidade e ambiguidade do conceito. ${ }^{447}$

\footnotetext{
${ }^{444}$ MARTINS-COSTA, Judith. op. cit., p. 299.

${ }^{445}$ Já referidos neste capítulo.

${ }^{446}$ TOMASEVICIUS FILHO, Eduardo. Informação assimétrica, custos de transação, princípio da boa-fé. 2007. Tese (Doutorado) - Faculdade de Direito da USP, Universidade de São Paulo, São Paulo, 2007.

${ }^{447}$ A jurisprudência está carregada da discrepância entre interpretações diametralmente opostas de boa-fé, algumas vezes servindo de fundamento para opiniões divergentes em relação ao mesmo caso, ambas apoiadas no princípio ou na cláusula geral. Judith Martins-Costa traz um desses acórdãos em que o voto vencido recorre ao fundamento da boa-fé para prover o recurso do autor, que pretendia a nulidade de cláusula contratual cumulada com restituição imediata de crédito, contra a administradora do consórcio, em razão da impossibilidade de adimplemento das prestações, e o voto vencedor também aplica a boa-fé, mas para enfatizar a obrigatoriedade e imutabilidade do pactuado. MARTINS-COSTA, Judith. op. cit., p. 422423. A autora usa este exemplo para demonstrar que a aplicação da boa-fé como princípio não expresso, dá ensejo à análise tópica e assistemática, que redunda em decisões disparatadas e até antinômicas. E sustenta que a fundamentação com base na boa-fé objetiva permitiria maior sistematização na apreciação judicial, evitando decisões conflitantes e garantindo maior segurança jurídica. Id. Ibid., p. 424-425. Entretanto, a experiência de uma década de aplicação da boa-fé objetiva não parece ter surtido o efeito propugnado.
} 


\section{CAPÍTULO 5. PERSPECTIVA ECONÔMICA DO DEVER DE INFORMAR}

Do aspecto econômico, contratos são meios para transferir bens àqueles que mais os valorizam. A informação que os instrui é definida como conhecimento de natureza instrumental, que tem potencial produtivo, ${ }^{448}$ representa poder, e sua distribuição implica alocação de riscos e benefícios entre os contratantes.

Todo contrato pressupõe uma série de presunções fáticas concebidas pelas partes que, quando equivocadas, acarretam custos. Esses erros podem ser evitados por meio da disciplina da informação que permeia os contratos, pois esta é o antídoto do erro. ${ }^{449}$

A assimetria informacional pode afetar o comportamento dos indivíduos e as normas legais desempenham o importante papel de determinar como as partes compartilharão as informações. A análise econômica se propõe a avaliar os efeitos das normas que disciplinam a informação na interação entre os agentes. ${ }^{450}$

Buscando incentivar a melhor distribuição da informação nas relações contratuais, estudos da perspectiva de Law and Economics, discutiram critérios para disciplinar o dever de informar desde a fase da pré-contratação, e estabeleceram parâmetros orientadores da distribuição mais eficiente do ponto de vista sócio-econômico. Alguns trabalhos se concentraram no processo de aquisição da informação, outros na sua natureza, e na eficiência ou ineficiência dos efeitos da distribuição entre as partes.

\section{Discussão das teorias formuladas pela Análise Econômica do Direito}

Partindo do estudo da disciplina do erro, Kronman apresenta o fundamento econômico da aplicação dessa regra jurídica pelos tribunais ingleses. Ciente de que a produção de informação é custosa, e que um contratante pode adquiri-la a um custo mais baixo que o outro, a solução do problema implica atribuir o ônus de eventual erro à parte que melhor pode evitá-lo, ou seja, a quem tem acesso mais fácil às informações relevantes

\footnotetext{
${ }^{448}$ SCHÄFER, Hans-Bernd; OTT, Claus. The economic analysis of civil law, cit., p. 356.

${ }^{449}$ KRONMAN, Anthony T. Mistake, disclosure, information and the law of contracts. Journal of Legal Studies, v. 7, n. 1, p. 1-33, 1978. Mas o autor lembra que nem todas as falhas de previsão são erros no sentido jurídico, pois é possível não conseguir prever determinado resultado futuro, somente em função de informação incompleta sobre a realidade. Id. Ibid., p. 4.

${ }^{450}$ BAIRD, Douglas G., GERTNER, Robert H.; PICKER, Randal C. Game theory and the law. Harvard University Press, 1998. p.79.
} 
em relação ao contrato. Daí a tendência jurisprudencial, apontada pelo autor, de acolher sempre o fundamento do erro bilateral para anular o contrato, e de ser mais exigente em relação ao erro unilateral, porque, em princípio, quem melhor pode evitá-lo seria o próprio contratante equivocado, desde que a parte contrária não tenha contribuído para induzi-lo ao engano. ${ }^{451}$

Se as partes distribuíram o risco, explícita ou implicitamente, com base no costume comercial ou na sua própria tradição negocial, a alocação deve ser respeitada. Havendo lacuna no contrato em relação à distribuição do risco decorrente da desinformação, também deve ser considerada, na aplicação da lei, a eficiência econômica, atribuindo-se tal risco à parte que pode obter informação com menos gastos, de modo a reduzir os custos da contratação. ${ }^{452}$

Como a distribuição da informação é geralmente desigual entre os agentes, que nem sempre a obtêm com a mesma facilidade, e considerando que somente a produção de alguns tipos de informação deveria ser incentivada, Kronman concebeu um critério fundado na forma de aquisição pelos contratantes. Com base nisso o autor distingue os casos em que se exige a divulgação da informação daqueles que comportam apropriação e a obtenção da vantagem daí decorrente em detrimento da contraparte. Se a informação tiver sido adquirida fortuita e gratuitamente, deve ser divulgada, mas, se sua obtenção tiver demandado esforço, talento pessoal ou investimento de qualquer outro recurso, poderá ser apropriada, para que possa render o correspondente benefício ao contratante que a detém. Permitir a utilização rentável da informação apreendida pela parte que a obteve mediante investimento, é recurso disponível ao sistema jurídico para estabelecer um direito de propriedade sobre os dados informativos. O não reconhecimento deste direito desestimula a busca de informações produtivas. ${ }^{453}$

Se a obtenção tiver sido casual, sem investimento de recursos, inclusive tempo, a imposição do dever de informar não acarretará ineficiência, porque não se poderia desestimular a busca de informações nos casos em que a parte não as tenha buscado deliberadamente. ${ }^{454}$ Em síntese, segundo a teoria de Kronman, a exigência da divulgação da informação adquirida casual e gratuitamente se justifica porque erros representam custos, e a divulgação de informação pode evitá-los. Como o agente que a obtêm não o faz

\footnotetext{
${ }^{451}$ KRONMAN, Anthony T. op. cit., p. 4-5.

${ }^{452}$ Id. Ibid., p. 4-5.

${ }^{453}$ Id. Ibid., p. 15.

${ }^{454}$ Id. Ibid., p. 14.
} 
deliberadamente, a imposição do dever de informar não tenderá a reduzir a produção de informação útil. ${ }^{455}$

O critério formulado por Kronman foi criticado com base em dois fundamentos. ${ }^{456}$ Primeiro, por ser de difícil operacionalização, porque nem sempre será possível saber como determinado agente obteve a informação, podendo-se, quando muito, presumir o modo de aquisição ${ }^{457}$. O autor reconhece que, na prática, é difícil distinguir a obtenção casual e gratuita da deliberada e custosa. Segundo, porque, ainda que fosse facilmente verificável o modo de aquisição da informação, o critério referente ao processo aquisitivo deliberado seria amplo demais, como assevera Eisenberg, que considera a visão dicotômica de Kronman inadequada, pois, embora os conceitos de aquisição causal e deliberada sejam importantes, são afetados por outros critérios, que lhes alteram a aplicação, subvertendo os resultados. $^{458}$ Eisenberg considera mais adequado estabelecer parâmetros a partir de elementos substantivos, como a natureza da informação. ${ }^{459}$

Transferindo o foco da análise do processo de aquisição da informação para elemento substancial do objeto do estudo, Cooter e Ulen estabeleceram outro critério orientador da disciplina do dever de informar, distinguindo entre informação produtiva e meramente redistributiva. Esta só transfere benefícios de um para o outro contratante, que a detém, e pode afetar o equilíbrio do contrato ao permitir que uma das partes se aproprie

\footnotetext{
${ }^{455} \mathrm{O}$ autor ilustra seu critério de aplicação do dever de informar com alguns exemplos. No primeiro caso, uma parte solicitou propostas para a confecção de óculos refletores para certa atividade empresarial, e a outra se propôs a fabricar 1400 peças a $\$ 0,22$ cada. Acompanharam o pedido de compra todas as especificações do modelo encomendado. Informado de que os óculos entregues estariam em desacordo com as especificações, o fabricante avisou a contraparte que o negócio estaria 'cancelado'. Esta comprou os óculos de outro fornecedor, e acionou o primeiro para cobrar a diferença entre o preço total dos óculos pago ao segundo fabricante e o preço contratado com o primeiro. Em juízo, este alegou que se enganou quanto às características dos produtos. O tribunal decidiu a favor do autor da ação, sob o fundamento de que o erro do réu só se justificaria se fosse conhecido da contraparte. Kronman aponta o acerto da decisão, pois o réu estava em melhores condições de evitar o erro, lendo cuidadosamente as especificações dos produtos encomendados. E seria muito mais difícil e custoso para a parte contrária fiscalizar a produção dos óculos. KRONMAN, Anthony T. op. cit., p. 5-6. Atribuindo as consequências do erro à própria parte equivocada o direito reduz custos de transação, porque evita que mais recursos sejam desnecessariamente direcionados à produção de informação pela parte que teria menos acesso a ela. Em outro exemplo, o licitante que submete uma proposta contendo um erro evidente de cálculo, ou facilmente constatável pela discrepância com as demais propostas, seria normalmente liberado da obrigação pactuada, sem pagamento de indenização. Neste caso, uma parte sabia ou deveria saber que a outra estava errada a respeito de elemento essencial do contrato, e poderia tê-la corrigido. Mas se o erro não fosse facilmente reconhecível pela contraparte, não se justificaria impor-lhe o ônus respectivo, como se ela fosse o contratante que melhor poderia evitá-lo. Id. Ibid., p. 6-7.

${ }^{456}$ Especialmente EISENBERG, Melvin. Disclosure in contract law. California Law Review, n. 91. p. 16451692, 2003; e FABRE-MAGNAN, Muriel. op. cit., p. 99-120.

${ }^{457} \mathrm{O}$ autor reconhece que, na prática, é difícil distinguir a obtenção casual e gratuita da deliberada e custosa. KRONMAN, Anthony T. op. cit., p. 13.

${ }^{458}$ EISENBERG argumenta que há hipóteses em que se deveria impor o dever de divulgar informação adquirida deliberadamente, em função de outros critérios. EISENBERG, Melvin. op. cit., p. 1663.

${ }^{459}$ Id. Ibid., p. 1663-1664.
} 
indevidamente dos ganhos a que a outra faria jus. A produtiva gera riqueza, um ganho líquido em bem-estar social, propiciando destinação mais eficiente dos recursos, o que interessa ao desenvolvimento econômico. Por isso, caberia ao poder público incentivar a criação e descoberta de informação geradora de riqueza, subsidiando pesquisas, atribuindo direito de propriedade de forma a facilitar a apropriação dos resultados. Concluem, pois, que o dever de informar, em princípio, não deve ser imposto se a informação for produtiva, permitindo que esta seja apropriada pela parte que a descobriu ou adquiriu. ${ }^{460}$

Cooter e Ulen asseveram que, para autorizar a apropriação da informação e afastar a imposição do dever de transmiti-la à contraparte contratual, é necessário combinar a natureza produtiva da informação, com a forma de aquisição, que deve resultar de investimento de recurso, como tempo, estudo, pesquisa, dinheiro. Nesse caso, o Estado deve reconhecer ao detentor o direito de guardá-la da contraparte, e apropriar-se do benefício dela decorrente na distribuição de ganhos provindos do contrato. ${ }^{461}$ Os dois requisitos cumulativos do dever de informar seriam, portanto, a natureza redistributiva da informação e sua aquisição casual ou gratuita.

Os autores observam, contudo, que a maioria das informações que entremeiam os contratos apresenta concomitantemente aspectos produtivos e redistributivos. Exemplificam com o caso do comprador informado, que adquire um carro antigo pelo preço de um carro velho, porque o vendedor era mal informado a respeito do produto ofertado. A informação seria produtiva, nesse caso, porque o comprador informado sabe que o carro merecia tratamento especial e, com a compra, o bem foi destinado àquele agente que o valoriza mais. Mas, nesse caso, a informação também tem aspecto redistributivo, porque o ganho do comprador informado em decorrência da compra provavelmente excede o valor das despesas com o cuidado especial com o carro. ${ }^{462}$

Porém, a nosso ver, os fundamentos que permitem, nesse caso, a apropriação e a obtenção das vantagens dela decorrentes, seriam: primeiro, porque o especialista investe recursos para a descoberta de raridades a baixo preço, e só isso já bastaria para permitir-lhe a obtenção do respectivo benefício em detrimento da contraparte; segundo, por unificar conhecimento e controle, o que gera eficiência econômica. Os próprios autores sustentam que a eficiência recomenda a reunião do conhecimento e do controle sobre os recursos a custo baixo, incluindo os custos de transação concernentes à transmissão da informação e à

\footnotetext{
${ }^{460}$ COOTER, R.; ULEN, T. op. cit., p. 279-286.

${ }^{461}$ Id. Ibid., p. 283.

${ }^{462}$ Id. Ibid., p. 283.
} 
venda dos produtos. ${ }^{463}$ Mas não incluem este fator como requisito da fórmula por eles proposta.

A teoria formulada por Cooter e Ulen se compõe de quatro princípios que orientam a distribuição da informação entre os contratantes:

(i) fazer valer ${ }^{464}$ contratos baseados em diferentes níveis de informação produtiva especialmente se obtida com investimento de tempo e recursos;

(ii) assegurar a validade da maioria dos contratos baseados em diferentes níveis de informação de natureza mista (produtiva + redistributiva);

(iii) invalidar contratos baseados em diferenças de informação puramente redistributiva ou obtida casualmente sem esforço ou investimento; e

(iv) obrigar a divulgação de informações atinentes à segurança.

O primeiro princípio considera, como vimos, a natureza da informação, classificando-a em redistributiva ou produtiva, e justificando o incentivo institucional a esta.

O segundo princípio carece de objetividade, o que lhe subtrai a utilidade prática, pois remete à mesma dúvida inicial: quando exigir o dever de informar, ou quando a omissão vicia o negócio jurídico. A regra formulada pelos autores não define qual seria o critério distintivo, porque a expressão maioria não soluciona o problema, dificulta a aplicação deste princípio, e fragiliza o primeiro, dada a reconhecida existência de informação de natureza mista (que não é exclusivamente produtiva e nem redistributiva). Melhor seria que se excluísse o segundo princípio, e se alterasse o primeiro para abranger as informações predominantemente produtivas.

Exemplo sempre citado de assimetria informacional, em que se justificaria a apropriação da informação, é o do comprador especializado que adquire antiguidades ou livros raros, cujos atributos seus proprietários desconhecem, e, por isso, não valorizam. Um exemplo bem atual em relação ao mercado imobiliário no Brasil é o do especialista cuja atribuição é detectar o imóvel-chave para aquisição de área destinada à construção de empreendimentos. Esse imóvel é aquele sem o qual não se viabilizaria o empreendimento,

\footnotetext{
${ }^{463}$ COOTER, R.; ULEN, T. op. cit., p. 280-283, passim.

${ }^{464}$ Fazer valer e assegurar a validade são expressões usadas como traduções aproximadas do verbo to enforce.
} 
e que, se adquirido antes dos demais, será vendido sem que o proprietário se dê conta de seu real valor, decorrente da sua extraordinária utilidade para a finalidade pretendida pelo comprador. ${ }^{465}$ Neste caso, deve ser reconhecido o direito de apropriação dos benefícios da informação pelo contratante, porque, apesar do aspecto redistributivo, ela também é produtiva e proveniente de investimento de tempo ou outros recursos, e, reunindo conhecimento e controle, gera eficiência econômica.

Para ilustrar o critério do terceiro princípio, concernente à informação redistributiva que não comporta proteção legal, Cooter e Ulen discutem o caso do comprador que toma antecipadamente conhecimento da construção de uma rodovia e adquire área contígua a ela por preço muito inferior ao que valeria se a informação fosse pública. ${ }^{466}$ Argumentam os autores que investimento em informação redistributiva desperdiça recursos e impõe gastos extras para que os contratantes menos informados evitem perder renda para os mais informados. Por isso, não se deveria incentivar a busca deste tipo de informação, punindo os agentes públicos que as deixam vazar, para não atrair recursos à obtenção de informações privilegiadas ${ }^{467}$. Porém, neste caso, a informação não merece proteção da lei, não por ser redistributiva ou gratuita, mas exclusivamente por ser privilegiada. Se não fosse pela ilicitude da origem, essa informação poderia ser protegida, porque é tão eficiente quanto a do imóvel-chave, por exemplo, pois transfere a propriedade de quem a valoriza menos para quem a valoriza mais. Mas, como Cooter e Ulen não prevêem este critério da ilicitude da origem da informação (insider information), precisam forçar seu enquadramento em outra categoria. A nosso ver, seria mais adequado prever um critério especialmente dedicado à sanção das informações privilegiadas, em vez de tentar inseri-las em outros, menos adequados. ${ }^{468}$

O quarto critério de Cooter e Ulen distingue ainda as informações produtivas ou redistributivas das concernentes à segurança, apontando o dever de divulgá-las. Invocam o caso Obde v. Schlemeyer ${ }^{469}$, em que o vendedor oculta do comprador de um imóvel a infestação de cupins. Embora o vendedor não tenha exatamente mentido, pois o comprador

\footnotetext{
${ }^{465} \mathrm{O}$ valor do bem em questão não resulta exclusivamente da sua utilidade para o comprador, o que não deveria ser objeto de divulgação, qualquer que fosse o critério adotado, mas decorre das implicações do mercado de construção civil, relacionadas às possibilidades e restrições à construção de edifícios, que exigem o equacionamento do espaço de forma a atender às normas específicas.

${ }^{466}$ COOTER, R.; ULEN, T. op. cit., p. 282.

${ }^{467}$ Id. Ibid., p. 282.

${ }^{468}$ Esta crítica será retomada no último tópico deste capítulo.

${ }^{469}$ Obde v. Schlemeyer, 56 Wash. 2d 449, 353 P.2d 672 (1960), apud COOTER, R.; ULEN, T. op. cit., p. 287.
} 
nunca o inquirira a respeito, ele omitiu o fato ${ }^{470}$. Algum tempo depois, foi acionado pelo adquirente, que não pretendeu a rescisão do contrato, mas a indenização pelo valor gasto com a desinfestação. A ação foi julgada procedente, quebrando a tradição da jurisprudência americana $^{471}$, que, até então, não exigia a divulgação de informação ao contratante menos informado, fosse ele alienante ou adquirente. Os autores afirmam que, impondo o dever de informar, a decisão judicial evita futuros danos causados por falha de informação atinente a defeito de segurança, e reduz a necessidade de futuros adquirentes terem que investir recursos em providências defensivas em relação a este tipo de conduta omissiva dos alienantes. Salientam que, se o vendedor sabia da infestação e o comprador não, a venda separou conhecimento do controle, minando uma das finalidades do Direito Contratual ${ }^{472}$.

Essa regra se baseia na ideia de que a informação concernente à utilidade esperada do bem e à sua utilização conforme a função deve ser sempre transmitida à contraparte, se esta for o adquirente, pois, para restituir ao bem a utilidade esperada e recompensar o vendedor pelo preço, o adquirente terá que despender mais recursos. Mas esta regra só se aplica aos contratos comutativos e, por isso, deve considerar o sinalagma equivalente, no direito, à eficiência paretiana. Em função disso, eventual pretensão indenizatória do adquirente comportaria a apreciação da compatibilidade entre o preço de venda do imóvel e seu estado. Se o bem tiver sido vendido a preço abaixo do mercado, não caberia indenização pelo vício da infestação.

A solução baseada na utilidade e função do bem objeto da obrigação contratada coincide com a ditada pela regra da unificação do controle com a detenção da informação, e ambas justificam o regime jurídico do vício redibitório, o qual, para comportar proteção, não precisa estar relacionado à segurança do objeto da obrigação contratada. ${ }^{473}$

Da argumentação aqui desenvolvida se dessume que o âmbito de incidência do quarto princípio de Cooter e Ulen é estreito demais, pois não abrange as hipóteses em que,

\footnotetext{
${ }^{470} \mathrm{Na}$ lei brasileira este caso é de vício redibitório, exclusivo dos contratos sinalagmáticos, e comporta rescisão do contrato com devolução ou abatimento do preço, e cumulado com indenização, se o vendedor soubesse do vício. Aqui a doutrina entende que o fato de o comprador não ter perguntado a respeito não descaracteriza o vício, desde que o adquirente tenha examinado a coisa com ordinária diligência e que o vício não seja aparente, de fácil constatação. Por todos, CARVALHO SANTOS, J. M. op. cit., p. 350.

${ }^{471}$ Até então, a antiga norma era caveat emptor, que impunha ao comprador todos os cuidados referentes à compra. Embora ao vendedor não fosse permitido mentir, a omissão não era punida.

${ }^{472}$ COOTER, R.; ULEN, T. op. cit., p. 284-285.

${ }^{473} \mathrm{~A}$ infestação de cupins provavelmente não teria, no Brasil, a dimensão que tem nos EUA, razão pela qual faz sentido os autores a relacionarem este fato à segurança do bem. Mas o que se pretendeu salientar é que seja ou não relacionado à segurança, o defeito oculto que afeta a utilidade da coisa ou lhe diminui o valor, é tratado como vício redibitório, cuja disciplina prestigia a cooperação e estimula a confiança entre as partes, ao impor o fornecimento de informações pelo vendedor ao adquirente do bem.
} 
a despeito de não se referirem à segurança, os defeitos da coisa lhe afetam a utilidade ou a função, comportando, por isso, proteção do Direito.

Finalmente, a fórmula de Cooter e Ulen não considerou outro princípio, que nos parece muito útil como fator distintivo das hipóteses de cabimento da proteção, que é o da unificação de conhecimento e controle, algumas vezes invocado pelos autores, mas injustificadamente excluído da fórmula.

Os critérios estabelecidos por Schäfer e Ott também se baseiam essencialmente na produtividade ou improdutividade da informação, apontando a inconveniência de incentivar a informação improdutiva, que só beneficia quem dela se apropria, e o ganho deste corresponde à perda de outros. ${ }^{474}$

Ilustram a improdutividade da informação com o exemplo de um corretor que descobre futura alteração da lei de zoneamento, e adquire terrenos a preço irrisório, que centuplica em curto lapso de tempo, pois esta informação estaria disponível ao público, inclusive aos antigos proprietários, um mês depois. A justificativa da imposição do dever de informar seria, segundo os autores, o desestímulo à obtenção fortuita de proveito associada à informação privilegiada. ${ }^{475}$ Tal qual ocorre no exemplo de Cooter e Ulen, ${ }^{476} \mathrm{o}$ cerne do problema está na ilicitude da origem da informação, porque o fato de sua obtenção ter sido gratuita ou fortuita é irrelevante, pois se tivesse sido onerosa, a situação seria igualmente inaceitável. Aqui a análise econômica parece adotar, tacitamente, como critério subjacente, a ilicitude, conceito próprio da teoria jurídica, que veda a informação de origem espúria, e aplica-lhe a teoria do incentivo, concluindo que não se deve estimular o investimento de recursos para obtenção de informações privilegiadas.

A mera antecipação no acesso à informação (foreknowledge), que posteriormente estará disponível ao público, independente da conduta do agente que se antecipou para obtê-la, tem sido considerada por vários analistas como hipótese de incidência do dever de informar. Tratando da economia relacionada a pesquisa e desenvolvimento, e buscando meios de incentivar a atividade inventiva, Hirshleifer traçou a distinção entre a descoberta e a mera antecipação da informação, como critério para identificar o que se pode classificar como invenção. O autor mostra que a atividade inventiva implica descoberta, ou seja, o reconhecimento de algo que possivelmente já existisse, embora não fosse conhecido, e só

\footnotetext{
${ }^{474}$ SCHÄFER, Hans-Bernd; OTT, Claus. The economic analysis of civil law, cit., p. 356.

${ }^{475}$ Id. Ibid., p. 356-357.

${ }^{476} \mathrm{~V}$. notas 466 e 467.
} 
veio a sê-lo, em razão da ação do descobridor. A mera antecipação da informação só envolve prioridade de acesso, pois consiste na apreensão privada de dados que já existem e que estarão disponíveis ao público em geral, independentemente do agente que a eles teve acesso antes. ${ }^{477}$ Embora seu trabalho não tenha abordado o dever de informar, a distinção estabelecida por Hirshleifer pode ser usada para estabelecer parâmetros para a aplicação desse dever no processo de contratação.

Essa questão do acesso antecipado à informação nos remete ao famoso caso Laidlaw v. Organ, em que se discutiu o dever de divulgar à contraparte notícia que beneficiava o comprador e que se tornaria pública em questão de horas, embora a decisão judicial não tivesse considerado esse aspecto (foreknowledge). À época da guerra de 1812, entre Inglaterra e Estados Unidos, houve um bloqueio naval a New Orleans, como parte da estratégia bélica. Em 18 de fevereiro de 1815, anunciado por jornais ingleses o fim da guerra, a notícia chegou a um comerciante de tabaco (Organ), que, ciente de que a informação ainda não se tornara pública, adquiriu de Peter Laidlaw \& Co. certa quantidade de tabaco, a preço muito baixo em decorrência do bloqueio imposto ao porto de New Orleans. Com a publicação da notícia horas mais tarde, Laidlaw se recusou a entregar a mercadoria, alegando que fora enganado, porque no momento da venda, ainda não sabia que a guerra havia acabado e que havia sido levantado o bloqueio. Ao que consta, o comprador omitiu a notícia do tratado de paz, sem praticar indução dolosa comissiva, e a Suprema Corte entendeu que ele não teria o dever de informar, desde que ele não tivesse contribuído para o erro do outro. ${ }^{478}$

O problema do acesso antecipado à informação também foi examinado por Steven Shavell, que concorda com a imposição do dever de divulgá-la, por não ser socialmente útil, e, por isso, não comportar incentivo. O autor discute o valor da informação e a conveniência

\footnotetext{
${ }^{477}$ HIRSHLEIFER, Jack. The Private and social value of information and the reward to inventive activity, cit., p. 561-574. O autor ilustra foreknowledge como previsão do tempo, porque a informação será disponível ao público a despeito de não ser divulgada antecipadamente pelo agente que a ela teve acesso antes.

${ }^{478}$ A decisão da Suprema Corte não pôs fim ao processo, devolvendo-o para julgamento pelo júri, mas a fundamentação expõe a visão do tribunal na época, de que a cada um cumpre zelar por seus interesses (caveat emptor), como se depreende do pronunciamento do relator. CHIEF JUSTICE MARSHALL: "The question in this case is whether the intelligence of extrinsic circumstances, which might influence the price of the commodity and which was exclusively within the knowledge of the vendee, ought to have been communicated by him to the vendor. The Court is of opinion that he was not bound to communicate it. It would be difficult to circumscribe the contrary doctrine within proper limits where the means of intelligence are equally accessible to both parties. But at the same time, each party must take care not to say or do anything tending to impose upon the other. The Court thinks that the absolute instruction of the judge was erroneous, and that the question, whether any imposition was practiced by the vendee upon the vendor ought to have been submitted to the jury. For these reasons, the judgment must be reversed and the cause remanded to the District Court of Louisiana with directions to award a venire facias de novo." JUSTIA. US SUPREME COURT CENTER. Disponível em: <http://supreme.justia.com/us/15/178/case.html>.
} 
da imposição do dever de informar, focalizando dois aspectos, um subjetivo e outro objetivo: (i) qual das partes detém a informação; e (ii) se a informação é socialmente útil. ${ }^{479}$

Analisando a natureza da informação, conclui que, se for socialmente útil, ou seja, produtiva, comportará apropriação, como medida de estímulo à sua aquisição. Caso contrário, deverá ser divulgada à parte contrária. ${ }^{480}$ Inclui nesta categoria as informações que apenas antecipam um fato, mas não representam acréscimo de valor.

Examinando o aspecto subjetivo da informação, Shavell observa que os vendedores tipicamente sabem mais a respeito daquilo que vendem, mas tendem a informar à contraparte dados que valorizam os bens e omitir aqueles que os depreciam. Já a conduta dos compradores é inversa. Mas geralmente são estes que descobrem dados socialmente mais úteis atinentes ao bem, os quais agregam valor ao objeto da operação. ${ }^{481} \mathrm{E}$ normalmente a busca de tais dados decorre de investimento. Por isso, via de regra, as informações obtidas pelos compradores comportam proteção legal, autorizando-se sua apropriação. $^{482}$

A abordagem de Eisenberg é francamente favorável à imposição do dever de informar, como regra, com base em três razões de eficiência: (i) o princípio da obrigatoriedade dos contratos se justifica melhor com base em informação completa; (ii) a exigência de divulgação de informações economiza gastos que seriam desperdiçados com buscas de dados já conhecidos da contraparte; (iii) erros de uma parte não retificados pela outra aumentam os recursos que devem ser investidos na destinação de bens à sua melhor utilização. E acrescenta o fator moral, que aponta para a lealdade nos negócios. ${ }^{483}$ Mas o autor reconhece a tensão existente entre a regra de transparência e várias categorias de casos em que a imposição do dever de informar acarretaria ineficiência, por desestimular a busca por informações produtivas. ${ }^{484} \mathrm{O}$ princípio da transparência se aplicaria em relação às informações relevantes adquiridas fortuitamente, ou seja, obtidas no curso de atividades não engajadas nesse propósito; e às informações relevantes às quais o agente teve acesso antecipado (foreknowledge), mesmo que adquiridas deliberadamente; às informações detidas por vendedores; às privilegiadas, ou seja, obtidas por vias ilícitas ou impróprias; e

\footnotetext{
${ }^{479}$ SHAVELL, Steven. Acquisition and disclosure of information prior to sale. The RAND Journal of Economics, v. 25, n. 1, p. 20-36, Spring, 1994.

${ }^{480}$ Id. Ibid., p. 21.

${ }^{481}$ SHAVELL, Steven. Foundations of economic analysis of law. MA: Harvard Univiversity Press, 2004. p. 333.

${ }^{482}$ SHAVELL, Steven. Acquisition and disclosure of information prior to sale, cit., p. 20-22.

${ }^{483}$ EISENBERG, Melvin. op. cit., p. 1647.

${ }^{484}$ Id. Ibid.
} 
nas relações de confiança e credibilidade. ${ }^{485}$ As exceções ao princípio, ou as hipóteses às quais ele não se aplica são: (a) se o risco da desinformação tiver sido alocado à parte mal informada; (ii) se a parte mal informada foi avisada, mas não tomou providências para se informar; (iii) se o contexto social é típico de jogo entre comprador e vendedor. ${ }^{486}$

A despeito das críticas da maioria dos analistas, excetuados Kronman e Trebilcock, a informação meramente antecipada (foreknowledge) merece, a nosso ver, proteção legal, permitindo-se a apropriação do respectivo benefício, desde que atenda aos demais critérios da imposição do dever de informar, especialmente o da licitude da origem da aquisição. No estágio tecnológico atual, em que as informações são instantaneamente difundidas para o mundo todo, o acesso antecipado a elas só pode decorrer de duas circunstâncias: ou se trata de insider information, que não deve ser protegida por ser ilícita, ou a parte desinformada não teria se desincumbido a tempo do ônus de se informar. Uma hipótese de antecipação de informação, que não se caracterize como informação privilegiada, será rara. E, se não for privilegiada, o acesso antecipado à informação será válido, desde que renda melhor utilização e valorização dos recursos. A prioridade de acesso à informação, se obtida licitamente, tem valor, e, por isso, deve render o respectivo benefício àquele que logrou acessá-la primeiro. O fato de Hirshleifer ter distinguido entre a prioridade de acesso e a invenção, significa apenas que obviamente só esta poderá ser patenteada e figurar como objeto de propriedade intelectual, mas não quer dizer que o acesso prioritário à informação não tenha valor instrumental.

Analisando também a disciplina da informação que instrui os contratos da óptica de Law and Economics, Fabre-Magnan ${ }^{487}$ focaliza especialmente o direito francês, mas suas considerações se aplicam ao regime jurídico contratual de qualquer país de Civil Law e até de Common Law, dada a crescente aproximação dos dois sistemas no domínio dos contratos.

Segundo a distinção estabelecida pela autora, a informação que deve ser comunicada à contraparte pode ser essencial, que afetaria a própria decisão de contratar, e

\footnotetext{
${ }^{485}$ EISENBERG, Melvin. op. cit., p. 1656-1682, passim.

${ }^{486}$ Id. Ibid., p. 1683.

${ }^{487}$ FABRE-MAGNAN, Muriel. op. cit., p. 99.
} 
cuja omissão é apta a invalidar o negócio jurídico; ou material, ${ }^{488}$ que afeta as condições contratadas, e pode dar ensejo a indenização. ${ }^{489}$

Criticando o critério de Kronman, Fabre-Magnan assevera que o modo de obtenção da informação não pode servir de parâmetro à imposição do dever de informar, que eventualmente se revelará mais eficiente do que deixar cada parte zelar pelos próprios interesses. Acrescenta que a regra de Kronman seria pouco aplicável, primeiro, devido à dificuldade de determinar qual o modo de aquisição, e, segundo, porque esta raramente é casual ou gratuita, já que se considera custo qualquer tipo de investimento destinado a essa finalidade. ${ }^{490}$ Assevera que o critério da aquisição deliberada e custosa da informação não soluciona a disciplina do dever de informar, observando que, em muitos casos, mesmo quando a informação é obtida deliberadamente, não se justificaria sua apropriação. Argumenta que, se no caso da venda da casa infestada por cupins, o proprietário tivesse providenciado uma análise técnica da situação do imóvel, ou fosse arquiteto, a aquisição da informação teria sido deliberada e onerosa, à luz da doutrina de Kronman, e, mesmo assim, não se justificaria isentá-lo do dever de informar. Acrescenta que, se a informação tiver sido adquirida deliberadamente por uma pessoa e fortuitamente por outra, ambas integrantes do mesmo polo contratual, seria absurdo decidir o caso de forma diferente para cada uma delas. $^{491}$

Desenvolveu, então, uma teoria que não se baseia nem no modo de aquisição, nem no tipo de informação a ser ou não divulgada, mas na relação de pertinência desta com a obrigação de cada uma das partes. A base de sua tese é a distinção entre a informação relacionada à prestação da própria parte que a tem, e à da contraparte, concluindo que o dever de informar deve ser sempre exigido da parte que detém a informação concernente à sua própria prestação. Assim, o vendedor será sempre incumbido de comunicar ao comprador todos os fatos relevantes atinentes ao objeto da venda. Isso não acarretaria efeito negativo, pois não o desestimularia de buscar informação a respeito do que vende, mas até o incentivaria, pois estará ciente de que o descumprimento do dever legal lhe trará consequências. Por outro lado, não representaria desestímulo ao comprador, que sempre

\footnotetext{
${ }^{488}$ Material é um qualificativo usado no direito inglês para significar que concerne a fatos e não opiniões, e que é relevante, pois tem nexo lógico com outros fatos consequentes.

${ }^{489}$ Mas os demais autores desconsideram essa distinção.

${ }^{490}$ FABRE-MAGNAN, Muriel. op. cit., p. 109.

${ }^{491}$ Id. Ibid., p. 110.
} 
buscará informações relacionadas ao que pretende comprar. O efeito positivo seria evitar a dupla produção de informação para a mesma finalidade e o desperdício de recursos. ${ }^{492}$

Em suma, as contribuições dos analistas econômicos têm sido fundamentais para o desenvolvimento de uma teoria jurídica da informação e como parâmetro para a identificação dos problemas contratuais relacionados à assimetria informacional, e avaliação das normas destinadas à sua disciplina. As fórmulas dos sistemas jurídicos, apoiadas principalmente no padrão de boa-fé, carecem de operacionalidade, por serem vagas demais, não servindo de orientação segura para a aplicação do dever de informar. Daí a utilidade dos instrumentos conceituais da Economia, cujos subsídios, segundo Kötz, o Direito não deveria descartar a priori, como se detivesse monopólio divino sobre os critérios relevantes da tomada de decisão. ${ }^{493}$

O trabalho de Hirshleifer, uma década depois do estudo pioneiro de Stigler, teve o mérito de tratar informação, apesar de sua natureza peculiar, como bem suscetível de apropriação, demonstrando que, por isso mesmo, dependendo das circunstâncias, comportaria proteção legal como direito de propriedade.

A doutrina de Kronman tratou de identificar em que circunstâncias a informação que permeia o contrato desde a formação, pode ser objeto de apropriação, conferindo o respectivo benefício à parte que a detém. Embora sua análise comporte ressalvas, seja pela dificuldade prática da distinção proposta com base no modo de aquisição da informação, seja pela insuficiência do critério sugerido, representou um avanço na formulação da teoria.

A análise de Cooter e Ulen trouxe nova perspectiva para a questão, por ter focalizado a natureza da informação, distinguindo-a entre produtiva e redistributiva, e aplicando tal distinção como critério para a proteção legal também com base na eficiência econômica. ${ }^{494}$ Embora comporte algumas críticas, como as já referidas, o modelo por eles apresentado concatenou o critério substancial da natureza da informação com o do processo de sua aquisição, representando um desenvolvimento da teoria de Kronman.

Fabre-Magnan critica o critério de Kronman, e adota outro, também dicotômico, baseado na distinção entre a informação relativa à prestação da contraparte e a da própria parte, para impor a esta o dever de informar.

\footnotetext{
${ }^{492}$ FABRE-MAGNAN, Muriel. op. cit., p. 113-117.

${ }^{493}$ KÖTZ, Hein. op. cit., p. 6 e 19.

${ }^{494}$ Posner e Shavell combinaram os critérios de Kronman e de Cooter e Ulen, distinguindo a aquisição deliberada e onerosa da fortuita e gratuita, e informação produtiva da meramente redistributiva, como fundamentos da disciplina do dever de informar.
} 
Ao definir a transparência como princípio geral, relegando as hipóteses de apropriação da informação às exceções, Eisenberg aponta uma tendência que já vem sendo notada por outros estudiosos.

Os comentários conclusivos a respeito das contribuições aqui apresentadas serão deduzidos no tópico final do capítulo, com a proposição dos critérios que entendemos adequados.

\section{A crescente preocupação com a lealdade contratual e a tutela da informação}

O trabalho de Eisenberg, que define a transparência como regra, embora comportando amplas exceções que protegem a propriedade da informação e os benefícios daí advindos, confirma a crescente exigência em relação à divulgação de informações no âmbito contratual, tendência que vem sendo constatada por vários analistas. Sefton-Green sublinha a progressiva importância do papel desempenhado pelo dever de informar no direito europeu, que também sinalizaria esse padrão mais exigente imposto às partes desde a fase pré-contratual. ${ }^{495}$ No direito americano também se tem constatado movimento cada vez mais perceptível direcionado à exigência de transparência nas relações contratuais e nas negociações preliminares. ${ }^{496}$ Fabre-Magnan aponta o que considera o traço mais marcante da evolução recente do direito francês, representado pela multiplicação de deveres pré-contratuais de informação, instituídos por meio de legislação especial. ${ }^{497}$ Este fenômeno também foi verificado, no direito italiano, por Roppo, que vislumbra, na proliferação de regras especiais que impõem deveres de informar, além da função precípua de disciplinar a informação em determinados contratos, a indicação de um movimento do sistema jurídico em direção à maior exigência de transparência. Essas normas, apesar do menor âmbito de sua aplicabilidade, têm o valor sistemático de apontar essa tendência, que deve funcionar como orientação para o intérprete. ${ }^{498}$

A crescente exigência de boa-fé e lealdade, tanto antes como depois da conclusão do contrato, não é propriamente consequência da uniformização da legislação europeia dos contratos, que estendeu tal padrão para além das relações de seguro e consumo, e que se reflete na aplicação do dever de informar, uma das regras instrumentais da padronização do

\footnotetext{
${ }^{495}$ SEFTON-GREEN, Ruth (Ed.). op. cit., p. 397-398.

${ }^{496}$ BAIRD, Douglas G., GERTNER, Robert H.; PICKER, Randal C. op. cit., p.79.

${ }^{497}$ FABRE-MAGNAN, Muriel. op. cit., p. 99-100, e notas 2 a 6.

${ }^{498}$ ROPPO, Vincenzo. Il contratto, cit., p. 816.
} 
comportamento dos agentes. A tendência, que vem rendendo culto idólatra à boa-fé, resulta da internacionalização do comércio, da massificação dos negócios, da impessoalidade dos meios eletrônicos, e da progressiva complexidade dos contratos, que se converteram em processos longos e intrincados, envolvendo outros participantes, além dos protagonistas. E, mesmo nos contratos de execução instantânea, a impessoalidade e a assimetria informacional entre as partes também reclamam melhor proteção da confiança. O dever de informar é um dos instrumentos que podem cumprir tal função de forma mais eficiente e objetiva do que o padrão de boa-fé, cujos atributos positivos estão associados à amplitude de seu alcance, e não à incisividade de sua aplicação.

A crescente exigência legal de transparência nos remete à teoria formulada por Luhmann. Vimos que ele concebe a confiança como um fator redutor da complexidade social, pois tem a função de disciplinar informalmente as relações humanas nos grupos sociais menores, embora tenha que ser substituída pelo Direito, nos sistemas maiores e mais sofisticados, em que se torna impraticável o exercício eficiente de sua função disciplinadora. $^{499}$ Devido à crescente impessoalidade e complexidade das relações comerciais, e contando cada vez menos com o poder moderador e sancionador das normas sociais, o sistema jurídico tende a exigir cada vez mais transparência e lealdade dos contratantes, com o objetivo de assegurar a confiança recíproca, como se compensasse a fragilidade das regras informais. ${ }^{500}$

Mas a complexidade dos negócios e a globalização do comércio não induzem à imposição indiscriminada ou absoluta do dever de informar, sob pena de se criarem outras ineficiências tão nocivas quanto as geradas pela assimetria informacional, como tipicamente decorre da regulação desmedida.

\section{Dever de informar. Pressupostos e Fundamentos}

São pressupostos da imposição do dever de informar a existência de assimetria informacional entre as partes, e a legitimidade da desinformação, que deve ser justificada, e não imputável exclusivamente à própria parte mal informada. Esta justificação concerne

\footnotetext{
${ }^{499}$ Já discutida no capítulo 3, LUHMANN, Niklas. op. cit.

${ }^{500}$ Como pondera Farnsworth, com a maior complexidade dos negócios, que envolvem mais interessados, e exigem longas tratativas e o acompanhamento de profissionais de diversas áreas, o regime pré-contratual não mais poderia restringir-se às regras de oferta e aceitação, como no século XIX. FARNSWORTH, E. Allan. Precontractual liability and preliminary agreements: fair dealing and failed negotiations, cit., p. 218219 e 285-286.
} 
à dificuldade ou ao custo de obtenção da informação. Mas o vínculo existente entre as partes, seja em razão de amizade, parentesco, ou histórico comercial, poderá caracterizar relação de confiança, justificando a desinformação de uma das partes, que se fia nas informações providas pela outra.

Os dados cuja divulgação a lei exige devem constituir fato material (e não opinião) relevante em relação aos próprios contratantes ou ao objeto do contrato, inclusive às obrigações convencionadas e respectivas prestações. Considera-se relevante a informação que afetaria a decisão de contratar ou que alteraria as condições contratadas ou as da contratação.

As duas regras básicas que orientam o regime da informação estão em permanente confronto: uma delas impõe a cada parte o ônus de se informar, e a outra protege o direito de ser informada da parte desfavorecida pela assimetria informacional. Na tentativa de resolver a tensão entre a imposição do dever de informar e a proteção do direito da parte mais informada se beneficiar da informação, há que se considerar o trade-off entre as duas soluções jurídicas, pois geralmente o benefício de uma corresponde ao custo da outra e vice-versa. Isso recomenda a ponderação das soluções conflitantes, que implica a análise dos efeitos positivos e negativos da adoção de cada uma delas, no contexto ao qual será aplicada.

O contrato geralmente articula interesses contrapostos, pois, embora as partes objetivem realizar a mesma operação, cada uma pretende auferir proveito para si, e, sempre que a vantagem de uma representar a desvantagem da outra, seus objetivos serão, em princípio, antagônicos.

Invocando a distinção feita por Isaiah Berlin entre a liberdade positiva e a negativa, Nili Cohen aplica esses dois conceitos ao contrato para explicar a autonomia contratual sob a óptica inglesa, segundo a qual as partes são livres não só para instituir regras às quais voluntariamente se submetem, mas igualmente livres para não se obrigarem antes da conclusão do contrato. ${ }^{501}$ Porém, existe uma dupla face da liberdade não mencionada no texto, e que bem retrata o contrato: a autonomia privada é a articulação de duas liberdades que se contrapõem e se contrastam até os seus respectivos limites, pois uma restringe a outra. Esse natural antagonismo entre os dois polos contratuais sugere que, com exceção dos casos excepcionais, como os contratos que envolvem relações fiduciárias, em que uma

${ }^{501}$ COHEN, Nili. op. cit., p. 25. 
das partes é contratada para zelar pelo interesse da outra, ou aqueles definidos como de máxima boa-fé, a cooperação pré-contratual é uma proposição um tanto utópica, por pretender transformar o auto-interesse em altruísmo.

Por isso, não é de se esperar zelo altruísta de uma parte em relação aos interesses da outra, sempre que a proteção destes implicar o sacrifício dos seus próprios. Daí decorre que os deveres de cooperação e de informação na fase de formação do contrato devem ser interpretados de acordo com esse contexto, a menos que se trate das hipóteses excepcionais mencionadas.

Assim, seria absurdo exigir a divulgação da informação detida pelo comprador que encontra, ainda que casualmente e sem custos, uma raridade a preço irrisório, como nos exemplos da compra da obra de arte ou do Stradivarius, não identificados como tais pelo vendedor, mas reconhecidos pelo comprador.

Porém, o contexto pré-contratual não é suficiente para justificar a apropriação da informação, porque, se assim fosse, o vendedor também não estaria sujeito ao dever de informar. E, via de regra, está. Tanto nos exemplos do quadro e do violino, como no da fazenda usada pelo proprietário para atividade agro-pecuária, e adquirida por alguém que sabia haver minério no solo, não se pode exigir dever de informar, porque foi a descoberta do comprador que agregou valor ao bem. De acordo com a utilidade aplicada aos bens pelos respectivos proprietários, só se poderia supor que o valor de mercado deles correspondia ao efetivo preço de venda. Foi a descoberta dos adquirentes que propiciou utilização diversa dos bens, aumentando-lhes o valor. Portanto, não haveria fundamento para anulação do contrato por erro, porque o valor acrescido ao bem pelo comprador deve render benefício a este e não ao vendedor. Descoberta é informação, e, como tal, pode e deve ser apropriada, rendendo frutos àquele que a faz. Portanto, não é apenas injusto, como classifica Fabre-Magnan, ${ }^{502}$ mas tecnicamente incorreto impor o dever de informar em tais circunstâncias. Se o comprador for obrigado a desvendar informações dessa natureza, ficará à mercê do vendedor, que se apropriará delas em seu próprio benefício, leiloando o bem pelo maior preço possível. ${ }^{503}$ A percepção de que a vantagem do alienante corresponderá à desvantagem do adquirente, cuja descoberta permitiu utilização mais valiosa do bem, enfatiza a evidência de que a proteção jurídica deve prestigiar o direito deste.

\footnotetext{
${ }^{502}$ FABRE-MAGNAN, Muriel. op. cit., p. 119.

${ }^{503}$ Id. Ibid., p. 110-112.
} 
Ainda que, numa dessas hipóteses, a descoberta tivesse sido fortuita e gratuita, não caberia o dever de informar, pois o proprietário tem acesso mais fácil, ou pelo menos igual, à informação, razão pela qual seria ônus seu informar-se sobre o próprio bem. Eventual assimetria informacional deveria ser debitada ao vendedor, fosse por mero desinteresse, negligência ou imperícia.

Como argumenta Michael Trebilcock, a imposição de dever de divulgar informação adquirida fortuitamente também pode levar à utilização ineficiente de recursos, que, se não descobertos pelo comprador, acabariam sendo subutilizados e menos valorizados. Em prol de seu argumento, invoca a hipótese da descoberta casual de petróleo por um pedestre que passava por acaso pela periferia de uma fazenda, cujo dono não suspeitava dos atributos de suas terras. Assevera que, neste caso, a imposição do dever de informar desestimulará as negociações e retardará ou inviabilizará o movimento eficiente dos recursos da menos para a mais valorizada utilização. ${ }^{504}$

A proteção do direito do comprador de apropriar-se da informação é eficiente do ponto de vista econômico, porque, além de incentivar a busca de informações por parte dos compradores, não desestimula os vendedores de buscá-las por estarem cientes da possibilidade de arcar com as consequências de sua decisão. Além disso, a proteção do direito do comprador de se apropriar da informação também se revela eficiente, por reunir conhecimento e controle. ${ }^{505}$

Segundo a teoria dos jogos, não faz sentido exigir que o eventual comprador informe o vendedor sobre o bem objeto da aquisição, porque, ainda que este não saiba de atributos do bem, conhecidos da outra parte, e lhe seja difícil descobri-los, o vendedor pode prever probabilidades e inferir informações do comportamento da contraparte, e geralmente o faz. ${ }^{506}$ Trata-se de jogo de informação incompleta, em que a parte desinformada coloca suas probabilidades inicialmente de acordo com sua própria impressão, mas depois as atualiza, segundo a regra de Bayes, inferindo dados sugeridos pela ação da parte informada. O perfeito equilíbrio bayesiano será alcançado desde que as crenças e as estratégias dos jogadores sejam consistentes com suas próprias ações, e com as da contraparte. ${ }^{507}$ Este jogo é intuitivo, como observam os autores, que o ilustram com

\footnotetext{
${ }^{504}$ TREBILCOCK, Michael J. The limits of freedom of contract. Harvard University Press, 1997. p. 113. ${ }^{505}$ COOTER, R.; ULEN, T. op. cit., p. 284-285.

${ }^{506}$ BAIRD, Douglas G., GERTNER, Robert H.; PICKER, Randal C. op. cit., p. 80.

${ }^{507}$ Id. Ibid., p. 83-84.
} 
uma história ficcional, mas sempre recorrente, sob várias formas, na vida real. ${ }^{508} \mathrm{O}$ exemplo transcrito demonstra que a ação de um jogador pode transmitir a outro informação que pretendia omitir e que, de fato, pensa ter omitido. E isso poderá ser suficiente para que o vendedor extraia inferências da conduta do comprador.

Em alguns casos, para inferir o interesse maior de um proponente, basta que o vendedor saiba algum dado pessoal dele, relevante com relação ao bem. Exemplo corriqueiro é o do imóvel contíguo: todo imóvel vale mais quando o interessado na compra é o seu vizinho. Como o vendedor tende a se aproveitar dessa situação, porque não há nada como o interesse de um vizinho para elevar o preço de um imóvel, qualquer estratégia omissiva do pretendente se justifica como defesa legítima.

O equilíbrio bayesiano conota a ideia de que jogadores desinformados avaliam determinadas situações, atribuindo-lhes certas probabilidades, e as atualizam, quando outros jogadores praticam ações aptas a transmitir informações que alteram a conjuntura dos fatos anteriormente avaliados. Embora esse modelo de jogo se aplique a quaisquer jogadores, desde que presentes as circunstâncias aludidas, restringimos a aplicação à hipótese em que o comprador é a parte mais informada, porque, além de todos os demais fundamentos anteriormente deduzidos, é pouco provável a possibilidade de um perfeito equilíbrio bayesiano na situação inversa. Tanto é que Baird, Gertner e Picker reconhecem que são mais complicados os casos em que a informação pode ser revelada, mas o outro jogador não tem como distinguir quem a possui e se cala, daquele que não a possui. Neste caso, é cabível instituir normas para disciplinar o dever de informar, mas estas só surtirão efeito se o Poder Judiciário puder distinguir entre os agentes que omitem informação e aqueles que efetivamente não a possuíam. ${ }^{509}$

Ao contrário do comprador, o vendedor não deve apropriar-se de informação relevante, concernente à sua própria obrigação, ou ao objeto desta, que é a prestação.

\footnotetext{
${ }^{508}$ Reconhecendo a utilidade de ilustrações para elucidar teorias, transcrevemos aqui o exemplo de equilíbrio bayesiano no filme The Maltese Falcon. O protagonista passa muitos anos tentando achar a estatueta de um falcão incrustada em pedra preciosa, que os cavaleiros de Malta tinham oferecido em tributo ao rei da Espanha. Finalmente, ele a encontra em Istambul nas mãos de um general russo. A estatueta estava coberta com um esmalte preto e parecia ser apenas uma curiosidade de pequeno valor. Ele tenta comprá-la, mas o general se recusa a vendê-la. Dois de seus aliados tentam, então, roubar a peça. No final, eles descobrem que a estatueta roubada era apenas uma imitação que o general russo havia colocado no lugar da original, depois da oferta de compra. É claro que o protagonista não havia contado para o general que a estátua era incrustada em pedra preciosa, e se depreende do contexto que, até então, o general não sabia dos atributos valiosos da estatueta, mas os inferiu com base na avidez do pretendente. O comprador cometeu o erro de oferecer demais. Por isso, seus aliados o culparam por ter estragado tudo com a inadvertida tentativa de compra. BAIRD, Douglas G., GERTNER, Robert H.; PICKER, Randal C. op. cit., p. 81-82.

${ }^{509}$ Id. Ibid., p.119.
} 
Ciente de que lhe incumbe o ônus de informar a respeito de seus bens e interesses, e de que eventual omissão ou distorção de informação possa acarretar-lhe responsabilidade perante o comprador, o vendedor será induzido a informar a verdade. ${ }^{510}$ Essa exigência legal, via de regra, será eficiente. Primeiro, porque a apropriação de informação pelo vendedor acarreta desperdício de gastos pela contraparte na pesquisa de informações, pois, tenderá a compelir o comprador a buscá-las por seus meios, que geralmente serão mais onerosos do que os do vendedor, que tem acesso direto à informação. E a maioria das informações será produzida em duplicidade, pois dificilmente o comprador descobre atributos do bem que o vendedor desconhece. Portanto, o dever de informar evitaria desperdício de recursos, funcionando como redutor de custos de transação. Segundo, porque a providência legal não desestimulará o comprador de buscar informações concernentes ao que ele pretende adquirir, pois naturalmente terá incentivo por conhecer o que pretende comprar.

Os princípios aplicáveis a compradores e vendedores se estendem aos contratantes, em geral, dependendo de se tratar de informação relativa à sua própria prestação ou à da contraparte.

Em suma, o ônus da informação e o respectivo risco da desinformação devem, em princípio, ser impostos àquele que teria acesso mais fácil à informação (cheapest cost bearer) e àquele que estaria mais apto a evitar as consequências da desinformação (best cost avoider). O agente que puder fazê-lo ao menor custo será, pois, incumbido do dever de informar.

Esta regra funciona tanto para a fase pré-contratual como para a posterior à conclusão do contrato, acentuando-se, a partir daí, o dever de cooperação, porque, uma vez celebrado o negócio jurídico, seu cumprimento deverá ser objetivo comum das partes, pois a articulação de posições antagônicas encontra o ponto de equilíbrio na conclusão do contrato.

\section{Proposição e Conclusão}

Usando subsídios da análise econômica e da tradicional, a disciplina da informação aplicada ao Direito Contratual poderia ser formulada com base nas seguintes regras:

1. Proteção da informação predominantemente produtiva e da apropriação da respectiva renda pelo contratante informado;

\footnotetext{
${ }^{510}$ Mas a lei só acarretará esse efeito, se a condenação em ação indenizatória representar uma ameaça crível.
} 
2. Proteção da informação adquirida licitamente mediante investimento de recursos, seja ela produtiva ou redistributiva;

3. Nos contratos comutativos, imposição do dever de divulgar ao adquirente as informações concernentes à estrutura e segurança, à utilidade e função do bem objeto do negócio jurídico;

4. Nos contratos de execução diferida ou continuada, imposição do dever de autorizar, no ato da contratação, a contraparte a consultar dados constantes de registros cadastrais, ou outros registros de informações concernentes ao objeto do contrato ou à capacidade e disponibilidade da parte em relação ao cumprimento do pactuado;

5. Nos contratos considerados de máxima boa-fé, e nas relações fiduciárias, o dever de informar é absoluto, cumprindo às partes informar-se reciprocamente a respeito dos fatos referentes a si próprias, ao objeto e às condições do contrato;

6. Imposição do dever de informar fatos ocorridos no curso da execução do contrato, aptos a alterar a repartição de riscos, afetar o equilíbrio dos ganhos contratuais, ou comprometer o futuro cumprimento do contrato.

As duas primeiras regras já foram comentadas. E apesar de terem sido criticadas por insuficiência ou falha de operacionalidade, funcionam bem quando combinadas entre si. Tanto que mesmo os que eventualmente as criticam, acabam invocando seus fundamentos para justificar a aplicação de outras regras. ${ }^{511}$

A segunda regra comporta ainda menção especial. A consideração da licitude, critério próprio da teoria jurídica, se justifica para impedir a proteção legal das informações privilegiadas. A combinação de critérios da ciência jurídica e da econômica enfatiza a relação de complementaridade e interdependência entre elas, cujos conceitos podem e, a nosso ver, devem ser utilizados conjuntamente, propiciando uma visão multifacetada da realidade. Como ela, de fato, é.

A terceira atende a dois princípios: um que diz respeito à reunião do conhecimento com o controle, e o outro que se resume na presunção de que cada um sabe (ou deve saber) mais do que é seu. Com base na regra de que é ônus de cada um se informar sobre seus

\footnotetext{
${ }^{511}$ Como FABRE-MAGNAN, Muriel. op. cit. e EISENBERG, Melvin. op. cit.
} 
próprios bens e interesses, não se exige que o comprador que detenha informação sobre um bem, a desvende àquele de quem pretende comprá-la, porque se presume que o conhecimento dos atributos dos próprios bens é ônus do proprietário e, por isso, essa ignorância não enseja proteção.

A quarta regra concerne ao processo de screening, em que o contratante mal informado busca informações da contraparte no intuito de evitar a seleção adversa, e o direito deve facilitar tal procedimento. De nada valerá impor o dever de informar se as informações não puderem ser conferidas, ${ }^{512}$ o que ocorrerá caso o acesso da contraparte à verificação das informações não seja garantido ou seja dificultado.

A quinta regra enfatiza o que já deveria ser evidente: se o contrato pertence à categoria da máxima boa-fé, este superlativo, por óbvio, não pode ser interpretado como um aparato linguístico ornamental. A partir do próximo capítulo examinaremos especificamente o dever de informar no seguro privado, que é o paradigma dos contratos uberrimae fidei. Nas relações fiduciárias em geral, e a fim de mitigar problemas de agência, a lei também deve impor o dever de informação, de lealdade e veracidade.

A última regra tem por finalidade limitar os efeitos do moral hazard, freqüente nos contratos de execução diferida, em que uma parte não pode monitorar as ações da outra em relação ao cumprimento da obrigação, ou o custo do monitoramento é alto.

A prescrição do dever de informar implica a cominação das respectivas sanções para o descumprimento. Se a omissão ou distorção configurar erro ou dolo, observados os critérios aqui considerados, será cabível a anulação, e, se caracterizar descumprimento do dever de informar, acarretará responsabilidade pela respectiva indenização.

Tratando-se de dever legal, o descumprimento enseja a aplicação da sanção independentemente de má-fé. Esta interpretação se coaduna com a de Roppo, já referida anteriormente: La parte che conosce (o dovrebbe conoscere) dati rilevanti per la valutazione del contratto dal punto di vista di controparte, e sa (o dovrebbe sapere) che questa invece li ignora, ha il dovere di informarne controparte. ${ }^{513}$ Portanto, à parte a quem foi legalmente atribuído o dever de informar não se desonera com a alegação de ignorância, exceto se escusável. Do mesmo modo, a negligência e demais formas culposas

\footnotetext{
${ }^{512}$ BAIRD, Douglas G., GERTNER, Robert H.; PICKER, Randal C. op. cit., p.79.

513، A parte que conhece (ou deveria conhecer) dados relevantes para a valoração do contrato do ponto de vista da contraparte, e sabe (ou deveria saber) que esta os desconhece, tem o dever de informá-la”. (grifos nossos) ROPPO, Vincenzo. Il contratto, cit., p. 177.
} 
também não são aptas a exonerá-la do cumprimento do dever. A possibilidade de violação da boa-fé por simples culpa é corroborada pela doutrina predominante. ${ }^{514}$ Como orientação para os aplicadores da lei, o Restatement 2 nd. of Contracts cataloga os tipos de condutas violadoras da boa-fé, incluindo a falta de diligência, que se traduz por negligência, o que faz sentido, porque, no direito americano como no inglês, a boa-fé se resume em todo comportamento que frustra o que o outro contratante pode razoavelmente esperar do contrato. Esta interpretação foi inspirada no famoso artigo de Robert Summers, citado anteriormente. ${ }^{515}$ George Cohen sustenta que o oportunismo e a negligência dão ensejo à quebra do padrão de boa-fé e aos deveres nele implícitos. ${ }^{516}$ Pondera que os analistas deveriam combinar os dois enfoques analíticos do direito contratual: um baseado na ideia do least cost avoider, que visa coibir comportamentos negligentes na contratação, punindo a parte que falha em tomar precauções justificadas com base no custo; e o outro objetiva impedir condutas oportunistas que violam disposições contratuais ou normas sociais. ${ }^{517}$

A instituição do dever de informar cujo descumprimento é punível também por culpa se refletirá na distribuição do ônus da prova.

À luz da regra da distribuição do ônus da prova insculpida no art. 333, do Código de Processo Civil, à parte que reclama a falta ou falha de informação, incumbe a produção da prova de todos os elementos constitutivos de seu direito. A ela cabe demonstrar que a informação é relevante em relação à decisão de contratar e às condições da contratação. ${ }^{518}$ A prova da inexigibilidade da divulgação da informação ou do cumprimento do dever ficaria a cargo do devedor da informação. ${ }^{519}$

Mas a produção de todas essas provas só será necessária se a divulgação da informação depender da observância do padrão de boa-fé ou se a pretensão indenizatória se basear na disposição legal relativa ao ato ilícito. ${ }^{520}$ Nestes casos, se aplicariam as aludidas regras de distribuição de ônus da prova.

\footnotetext{
${ }^{514}$ SACCO, Rodolfo. La buona fede nella fase precontratualle, cit., p. 247-248; ROPPO, Vincenzo. Il contratto, cit., p. 177; SCHÄFER, Hans-Bernd; OTT, Claus. The economic analysis of civil law, cit., p. 390; COHEN, George M. The negligence and opportunism tradeoff in contract law. Hofstra Law Review, v. 20, p. 941-1016, 1991-1992.

${ }^{515}$ SUMMERS, Robert. Good faith in general contract law and the sales provisions of the Uniform Commercial Code, cit., p. 216.

${ }^{516}$ COHEN, George M. op. cit., p. 941-1016.

${ }^{517}$ Id. Ibid., p. 942.

${ }^{518}$ SILVA, Eva Sónia Moreira. Da responsabilidade pré-contratual por violação dos deveres de informação. Coimbra: Almedina, 2006. p. 201.

${ }^{519}$ Id. Ibid., p. 203-204.

${ }^{520}$ Nestas duas hipóteses o ônus da prova sempre incumbirá ao credor da informação.
} 
Porém, a positivação do dever de informar implica a presunção da assimetria informacional desfavorável ao credor da informação, o que inverte o ônus da prova para a parte mais informada. Assim, só não sendo possível inferir a disparidade de informação pela mera subsunção do fato à norma, incumbirá à parte desinformada a prova de que a contraparte conhecia ou deveria conhecer a informação.

A responsabilização desta pode fundar-se em simples culpa, independente de má-fé, que agravaria a omissão ou a distorção. Mas a positivação do dever de informar aplicável a hipóteses específicas de incidência também induz à presunção da responsabilidade do devedor da informação, que comportaria prova em contrário. Ao contratante alegadamente informado cabe provar que não tinha a informação, ou que, apesar de ter agido com prudência e diligência, não achou que devia transmiti-la ao outro contratante. Isso equivale à presunção de culpa, porque incumbe ao culposo afastá-la, demonstrando sua diligência e prudência. Portanto, a prescrição legal do dever de informar ensejaria responsabilidade extracontratual por dolo ou culpa presumida, que facilita a prova para o credor da informação, porque implica inversão do ônus de sua produção. Se a violação da boa-fé por simples culpa é corroborada pela doutrina predominante, ${ }^{521}$ com mais razão se aplicaria tal interpretação ao dever de informar. Reitere-se, entretanto, que se o dever for expressamente previsto em lei, a culpa será presumida.

Esse sistema de presunções induzido pela prescrição de deveres legais é um dos fatores que torna a regra mais operacional do que o padrão, porque assegura melhor a eficiência da norma devido à maior facilidade procedimental.

Se a omissão de informação relevante atinente ao objeto do contrato ou da obrigação contratada pode, em tese, dar causa à anulação do contrato ou à indenização pelos prejuízos, com mais razão, a resposta falsa a uma pergunta relevante da contraparte. A razão econômica da regra é que a previsão de punição da falsidade induz as partes a confiarem na veracidade das informações prestadas durante as negociações preliminares, o

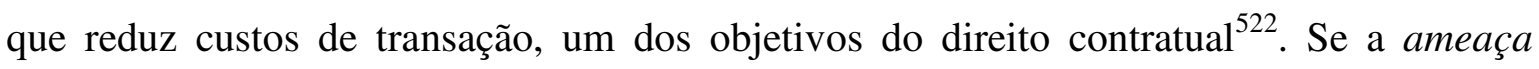
representada pela lei for crível, o que também exige eficiência em sua aplicação, as partes tenderão a cooperar, cumprindo esta outra função institucional do direito.

\footnotetext{
${ }^{521}$ SACCO, Rodolfo. La buona fede nella fase precontratualle, cit., p. 247-248; ROPPO, Vincenzo. Il contratto, cit.; MACKAAY, Ejan; ROUSSEAU, Stéphane. op. cit.; SUMMERS, Robert. Good faith in general contract law and the sales provisions of the Uniform Commercial Code, cit., p. 195-267.

${ }^{522}$ COOTER, R.; ULEN, T. op. cit., p. 286.
} 
O maior ou menor rigor na imposição do dever de informar decorre de escolhas públicas, que levam em conta fatores inerentes ao ambiente institucional, como circunstâncias históricas, contexto cultural, conjuntura sócio-econômica, convicções ideológicas, as quais influenciam as instituições sociais. No Brasil, ainda se constatam inúmeras evidências da complacência e da elasticidade exagerada das normas sociais, que desafiam sua eficiência como balizadoras das relações humanas, e tornam imprescindível a atuação mais objetiva e eficiente do Direito, para compensá-las, assegurando a confiança nas relações jurídicas. 


\section{CAPÍTULO 6. INFORMAÇÃO E OS SEGUROS PRIVADOS}

A informação que instrui os contratos funciona como guia orientador da escolha dos contratantes, indutor da atividade negocial e fator de incentivo ao comprometimento das partes. $^{523}$

Quando compartilhada, induz confiança recíproca, e, se assimétrica, tende a favorecer apenas a parte mais bem informada, que pode usufruir do benefício dela decorrente.

Porém, se a assimetria informacional der ensejo ao oportunismo, aumentar custos de transação, acarretando efeitos potencialmente lesivos, caberá às instituições aplainá-la. ${ }^{524} \mathrm{E}$ as normas jurídicas podem fazê-lo por intermédio dos institutos já examinados, especialmente o dever de informar. ${ }^{525}$

A análise do complexo mecanismo da operação de seguros, com suas idiossincrasias, demonstrará que, se a informação exerce relevante função no direito contratual em geral, mais acentuada é sua importância nos seguros privados.

As características sui generis da operação de seguros aliadas à multiplicidade e à relevância de suas funções justificam o tratamento especial do dever de informar no âmbito de tais relações jurídicas.

\section{A operação de seguro}

Se focalizado exclusivamente do aspecto jurídico, nas relações bilaterais entre segurador e segurado, o contrato de seguro não deixa entrever a complexa operação técnico-econômica subjacente, que viabiliza o cumprimento de sua função de garantia de riscos. Ele só pode ser compreendido em um contexto mais amplo ${ }^{526}$ do que o da simples

\footnotetext{
${ }^{523}$ Remete-se aqui à abordagem genérica do Cap. 1. A Incerteza e o Processo de Escolha

${ }^{524}$ Estes são os requisitos para disciplina da informação, segundo MACKAAY, Ejan; ROUSSEAU, Stéphane. op. cit., p. 390.

${ }^{525}$ Cap. 3. Assimetria Informacional e as Instituições: Regime da Informação nos Contratos.

${ }^{526}$ Comparato descreve o contrato de seguro como "unidade de um conjunto homogêneo de contratos do mesmo tipo". Argumenta que a operação na qual está inserido "implica a organização de uma mutualidade ou o agrupamento de um número mínimo de pessoas submetidas aos mesmos riscos, cuja ocorrência e intensidade são suscetíveis de tratamento atuarial, ou previsão estatística, segundo a lei dos grandes números, o que permite a repartição proporcional das perdas globais, resultantes dos sinistros, entre todos os seus componentes". COMPARATO, Fábio Konder. Comentário a acórdão - Seguro - Cláusula de rateio proporcional - Juridicidade. Revista de Direito Mercantil, Industrial, Econômico e Financeiro, São Paulo, ano 11, n. 7, p. 102-112, 1972.
} 
troca entre uma prestação a cargo de uma empresa (segurador) contra o pagamento de um prêmio a cargo do tomador, para a hipótese de efetivação de um risco. ${ }^{527}$

A operação de seguros observa uma série de regras técnicas que viabilizam a avaliação dos riscos, sua classificação e reunião de acordo com cada categoria e a formação da carteira entre os componentes desse agrupamento organizado pela atividade seguradora.

A natureza complexa da operação de seguros requer, pois, que ela seja focalizada sob três aspectos: o técnico-econômico, o jurídico, e o social. ${ }^{528}$ De nenhum destes ângulos que se examine o instituto se pode ter dele visão integral. O traço distintivo mais marcante que o caracteriza só se revela quando examinado do ponto de vista técnico. Focalizaremos, por isso, este ângulo primeiro, para depois abordar o aspecto social e as funções do seguro para, então, tratar do aspecto jurídico.

\section{Aspecto técnico-econômico da operação de seguros}

O aspecto técnico-econômico é a base de toda operação de seguros, ${ }^{529}$ cuja existência depende do agrupamento de grande quantidade de segurados, expostos a riscos com características comuns, e que compõem a mutualidade, fundo comum organizado pelo segurador de modo a permitir a compensação dos riscos ${ }^{530}$.

Do ponto de vista econômico a nota distintiva do seguro é a garantia recíproca entre inúmeras economias expostas a riscos homogêneos, que se compensam.

Foi o desenvolvimento das ciências estatística e atuarial que viabilizou a instituição do seguro, como instrumento apto a cumprir a função de garantir os efeitos da materialização dos riscos suportados pela mutualidade de segurados. ${ }^{531}$ Este procedimento só se tornou possível com a aplicação de cálculos matemáticos ao tratamento do risco.

\footnotetext{
${ }^{527}$ STIGLITZ, Rubén S. Derecho de seguros. 5. ed. actual. y ampl. Buenos Ayres: La Ley, 2008. t. 1, p. 8.

${ }^{528}$ MELLO FRANCO, Vera Helena de. Lições de direito securitário: seguros terrestres privados. São Paulo: Maltese, 1993. p. 18.

${ }^{529}$ PICARD, Maurice; BESSON, André. Les assurances terrestres en droit français. Paris: Librairie Générale de Droit et de Jurisprudence, 1964. p. 1-3.

${ }^{530}$ Muitos autores se referem à dispersão, diluição ou risk pooling como característica fundamental da operação de seguro. Lambert-Faivre afirma que a dispersão de riscos garantidos é a base e a condição essencial da operação securitária, que só se pode realizar por compensação. Daí a conclusão de que os riscos enfrentados pela seguradora não correspondem à soma dos que compõem sua carteira. Em primeiro lugar, porque tais riscos não lhe foram transferidos, apesar da noção corrente de que ela os assume. Em segundo lugar, porque o mecanismo da operação securitária os dispersa entre os próprios segurados.

${ }^{531}$ MELLO FRANCO, Vera Helena de. op. cit., p. 17.
} 
Por isso, certas operações descritas como embriões ${ }^{532}$ do instituto, na Antiguidade e na Idade Média, não correspondem, na essência, a operações de seguro, como adverte Gasperoni. ${ }^{533}$ Mas, como já eram formas rudimentares de controlar risco, seja por transferência ou por rateio, propiciavam confiança, induzindo investimentos de recursos em atividades empreendedoras. ${ }^{534}$

O histórico da origem do instituto revela que a operação complexa com base matemática só se desenvolveria no século XVII, com a descoberta da teoria das probabilidades e os avanços científicos que possibilitaram o tratamento do risco.

Analisando o papel do risco na sociedade, Peter Bernstein observa que a possibilidade de controlá-lo constitui um dos fatores distintivos da civilização moderna, que colocou o futuro a serviço do presente. A reflexão sobre a natureza do risco e a tentativa de dissipá-lo por meio da matemática e da estatística substituíram a impotência diante do destino pelo poder de escolha racional $^{535}$. O Renascimento criou ambiente

${ }^{532} \mathrm{O}$ denominador comum a todas as formas embrionárias de seguro se resumia na equação risco, previdência, mutualidade e garantia, e a evolução do instituto mostra que sua função primordial através da história foi a preservação patrimonial e o incentivo ao exercício do comércio e ao desenvolvimento econômico.

${ }^{533} \mathrm{~A}$ reunião de esforços para enfrentar necessidades de sobrevivência sempre foi preocupação natural do homem, como comprovam entidades como a família, a tribo, e formas rudimentares de associação para auxílio mútuo, que, entretanto, não guardam nenhuma semelhança com o seguro. Contratos de características diversas, eventualmente reportados como origem do seguro, também não justificam a apontada pertinência. O instituto do foenus nauticum também não pode ser considerado embrião do seguro, porque lhe faltam as características essenciais deste. As guildas medievais, associações de assistência mútua contra danos provenientes de incêndios, naufrágios, roubos, e outros sinistros, tampouco podem ser tidas como antecessoras do instituto, por não terem os traços essenciais do seguro. Mesmo os contratos concebidos para tentar contornar riscos marítimos, nos países banhados pelo Mediterrâneo, especialmente a Itália, durante o intenso tráfego comercial da era medieval, não podiam ser assimilados ao seguro, pois se tratava de mútuos ou outros tipos contratuais, com cláusula acessória ou condição atinente a eventual ocorrência de sinistro. $\mathrm{O}$ autor aponta a origem mais remota do seguro nos contratos autônomos destinados ao tratamento do risco, concebidos a partir do século XIV, pois, nestes, intervinha um terceiro, que assumia o risco entre mutuante e mutuário, comprador e vendedor, mediante a paga de um prêmio, embora ainda não se dispusesse de mecanismo apto a dissipar o risco. Por isso, estes contratos não preveniam o risco mediante dispersão, mas apenas o transferiam ao segurador. Só em meados do século XVII, surge a operação de seguro nos moldes em que é concebida atualmente, desencadeada pelo incêndio que destruiu parte de Londres em 1666. GASPERONI, Nicola. Assicurazioni private. Torino: Unione Tipografica Editrice Torinese, 1959. p. 13-20, passim. Halperin aponta as mesmas origens dos seguros marítimo e terrestre, respectivamente. HALPERIN, Isaac. Seguros. Buenos Aires: Depalma, 1976. p. 1-2.

${ }^{534}$ Schäfer e Ott comentam que, como o mercador do século XIV só tinha um navio com o qual ele exercia sua atividade comercial, ele arriscava todo o seu patrimônio a cada viagem marítima, e por isso evitava buscar outras rotas, embora lucrativas, como o norte da África, para não agravar o risco com a travessia. Foi a possibilidade de rateio dos eventuais prejuízos entre componentes das corporações de ofício que permitiu a busca de outras rotas comerciais lucrativas, que representavam um risco maior. Segundo os autores, historiadores econômicos argumentam que a ascensão de Veneza nos séculos XIII e XIV, se deveu à criação daquelas instituições destinadas a administrar riscos dos comerciantes, relacionados com comércio marítimo.

${ }^{535}$ BERNSTEIN, Peter. Desafio aos deuses, a fascinante história do risco, cit., p. 1-3. A aleatoriedade do futuro foi substituída pela probabilidade sistemática, permitindo que o risco se tornasse mensurável e, por isso, previsível e controlável. Esse avanço foi desencadeado pelo contexto renascentista em que o ser 
propício a novas incursões no âmbito das ciências, quando as pessoas, libertas das restrições do passado, desafiaram crenças até então consagradas. Foi nessa época, em 1654, que o matemático francês Blaise Pascal foi desafiado a decifrar o enigma de dividir apostas entre dois jogadores, num jogo de azar, interrompido quando um deles estava vencendo. Pascal, com a colaboração de Pierre Fermat, solucionou o enigma levando à descoberta da teoria das probabilidades, que permitiu às pessoas a tomada de decisões de modo racional, com base em previsões cientificamente calculadas. ${ }^{536} \mathrm{Com}$ o tempo, a teoria das probabilidades passou a representar mais do que simples recurso a serviço dos apostadores, tornando-se eficiente instrumento de organização, interpretação e aplicação de informações. ${ }^{537}$

Como demonstrou Pascal, o acaso obedece a certas leis ${ }^{538}$, que permitem a mensuração de riscos, com base na teoria das probabilidades, ramo da matemática dedicado à análise dos fenômenos aleatórios. Como base para a estatística, a teoria é essencial a todas as atividades que envolvem análise quantitativa de grande número de dados.

Estatística é o estudo da coleta, organização, análise e interpretação de dados. A diferença básica entre as duas ciências é que, enquanto a teoria das probabilidades parte de determinados parâmetros genéricos para deduzir as probabilidades de uma amostra, a estatística faz o caminho inverso, partindo indutivamente de amostras para extrair inferências em relação ao todo.

\footnotetext{
humano passou a ser visto como apto a dirigir o próprio destino. Atribuídos na Antiguidade exclusivamente aos caprichos dos deuses e só desvendados por profetas e adivinhos, os fatos futuros e eventuais eram temidos porque envoltos nas trevas da ignorância. Esse temor amarrava a tomada de decisões, e, com isso, travava o desenvolvimento científico e econômico. Só a capacidade de administrar os riscos fez com que o homem se dispusesse a enfrentá-los, tomando decisões orientadas para o futuro e guiadas por instrumentos confiáveis, com isso, impulsionando o crescimento econômico. Id. Ibid., p. 20.

${ }^{536}$ BERNSTEIN, Peter. op. cit., p. 3.

${ }^{537}$ Id. Ibid., p. 4.

${ }^{538}$ LAMBERT-FAIVRE, Yvonne. Droit des assurances. 3. ed, Paris: Dalloz, 1979. p. 33. A autora remete a um exemplo muito simples para explicar a aplicação da teoria da probabilidade: num jogo de dados, um dado de seis faces, se perfeitamente simétrico, tem uma chance em seis, ou seja, uma probabilidade de 1/6, de jogado, cair sobre uma das faces. Pode-se ainda dizer que, o dado com suas 3 faces pares e 3 ímpares, tem 3 chances em 6 , ou uma probabilidade de $3 / 6$ ou 1/2 de cair de um lado par. Esta experiência permite compreender a definição da probabilidade matemática: que é uma relação do número de chances de realização de um evento, sobre o número de casos possíveis. Entretanto, se retomarmos o exemplo do dado, a experiência comprova que se pode jogar o dado seis vezes e ele não cair nenhuma vez no número 1 . Mas se multiplicarmos o número de experiências por 10, 100 ou 1000, se constatará que o dado cairá um determinado número de vezes do mesmo lado: a relação do número de resultados obtidos sobre o número de experiências tentadas é a frequência. Porém, a frequência experimental é sempre ligeiramente diferente da probabilidade matemática (teórica): esta diferença é chamada desvio. Mas se constata que quanto maior o número de tentativas, menor será o desvio, porque a frequência experimental se aproxima da probabilidade teórica e esta observação conduz à lei dos grandes números. Id. Ibid., p. 33-34.
} 
Probabilidade refere-se à possibilidade de que dado resultado venha a ocorrer, e sua interpretação objetiva fundamenta-se na frequência e intensidade dessas ocorrências. ${ }^{539} \mathrm{E}$ usada no cálculo do valor esperado, que é a média ponderada probabilística dos valores associados a todos os resultados possíveis de um evento, e da variabilidade, que consiste no grau de diferença entre os resultados possíveis de um acontecimento incerto ${ }^{540}$. Calculase o valor esperado, multiplicando-se o montante de eventual perda ou ganho, pela probabilidade de sua ocorrência.

Essas considerações genéricas já seriam suficientes para indicar a importância da informação no contrato de seguro. A análise de seu mecanismo confirmará esta asserção.

A operação securitária se apoia em fundamentos técnicos.

Para prever com a maior exatidão possível número e valor exatos dos sinistros que deverá eventualmente garantir, a seguradora recorre ao método estatístico, calculando as probabilidades sobre os dados de frequência e de custo médio de eventos passados. ${ }^{541}$ Os atuários calculam as probabilidades tentando prever o número de sinistros que se materializam em relação aos riscos segurados, a partir de estatísticas determinadas com base em eventos passados ${ }^{542}$. Observando muitos eventos em dado período de tempo, monta-se a tabela de frequência em relação à ocorrência de cada possível resultado, e a probabilidade apurada para determinado evento é o índice médio correspondente à expectativa de sua ocorrência ${ }^{543}$. Reunidos os riscos e calculado o volume de sinistros prováveis naquele determinado grupo, estabelece-se o montante provável das indenizações, estimando-se, com base nisso, a soma dos prêmios a serem rateados entre os segurados. ${ }^{544}$

O levantamento estatístico deve considerar grande quantidade de casos, por meio da aplicação da lei dos grandes números ${ }^{545}$. Com base nos resultados dessa operação, é efetuado cálculo de probabilidades, que será tanto mais exato quanto maior o número de

\footnotetext{
${ }^{539}$ PINDYCK, Robert S.; RUBINFELD, Daniel L. op. cit., p. 132.

${ }^{540}$ Id., loc. cit.

${ }^{541}$ Para que esses dados reflitam as probabilidades cientificamente consideradas devem ser observados eventos passados cientificamente coletados, de acordo com regras que lhes garantam credibilidade e permitam exploração racional. LAMBERT-FAIVRE, Yvonne. op. cit., p. 34-35.

${ }^{542}$ Id. Ibid., p. 33.

${ }^{543}$ VAUGHAN, Emmett J.; VAUGHAN, Therese M. op. cit., p. 37.

${ }^{544}$ MELLO FRANCO, Vera Helena de. Contratos: direito civil e empresarial. São Paulo: Ed. Revista dos Tribunais, 2009. p. 271.

${ }^{545}$ Segundo Bernstein, a constatação de Gottfried Von Leibniz de que a natureza estabelece padrões que dão origem à repetição dos eventos, mas apenas na maior parte dos casos, levou Bernoulli a criar a Lei dos Grandes Números e os métodos de amostragem estatística. A advertência de Leibniz "apenas na maior parte dos casos" forneceu a chave para a mensuração do risco. BERNSTEIN, Peter. op. cit., p. 4. Os conceitos de distribuição normal e de desvio de padrão constituíram a Lei das Médias e são ingredientes essenciais das técnicas modernas de quantificação de risco. Id. Ibid., p. 5.
} 
experiências trazidas pela frequência apurada, ${ }^{546}$ aproximando-se, assim, da probabilidade matemática pretendida. ${ }^{547}$ Quanto maior a amostra, melhor a certeza da estimativa. ${ }^{548}$

Para a composição das carteiras da seguradora são organizadas planilhas de classificação, nas quais se inserem os riscos, de acordo com as probabilidades de sua ocorrência, detectadas a partir dos dados informados pelo proponente. A seguradora depende, portanto, em grande parte, da informação do proponente, pois somente ele conhece, de fato, o risco a que está sujeito o interesse que pretende garantir.

Como a carteira contempla diferentes graus de riscos, a técnica exige que se contrabalancem os mais severos com aqueles cuja probabilidade é mais baixa.

Eventuais erros nessa operação afetarão, em primeira instância, a mutualidade, obrigada a suportar carga superior à capacidade do fundo comum, e, no limite, poderão acarretar a insolvência da seguradora. Se tais erros decorrerem de falha técnica atuarial, constituirão risco inerente ao negócio, e se atribuem à responsabilidade da empresa, cuja atuação diligente e prudente pode evitá-los. Mas, se provocados por omissões e distorções de informações relativas às características do risco, a despeito da diligência e prudência da companhia, são imputáveis ao proponente ou segurado que tiver agido com oportunismo $^{549}$. Estes devem ser evitados mediante disciplina rigorosa da informação no contrato de seguro, pois o equilíbrio da carteira também depende da exatidão das declarações do proponente. A exigência de máxima boa-fé e veracidade está diretamente associada ao papel da informação neste tipo contratual.

Como essas planilhas de riscos devem ser atualizadas à medida que se apresentem novas informações sobre os riscos já classificados, a lei exige que o segurado informe à seguradora incidentes suscetíveis de agravar o risco, a fim de possibilitar a manutenção do

\footnotetext{
${ }^{546}$ Esta relação é a essência da lei dos grandes números, que Emmet J. Vaughan e Therese Vaughan assim resumem: "the observed frequency of an event more nearly approaches the underlying probability of the population as the number of trials approaches infinity." VAUGHAN, Emmett J.; VAUGHAN, Therese M. op. cit., p. 37.

${ }^{547}$ Esta é a razão pela qual as companhias de seguro francesas se reuniram em seis grupamentos técnicos de ramos, que exploram todas as suas estatísticas em uma estatística comum, tecnicamente mais confiável. LAMBERT-FAIVRE, Yvonne. op. cit., p. 35.

${ }^{548}$ VAUGHAN, Emmett J.; VAUGHAN, Therese M. op. cit., p. 40.

${ }^{549} \mathrm{O}$ mecanismo da operação securitária incita condutas oportunistas, pois envolve numeroso grupo de desconhecidos e os riscos a que estão expostos seus interesses compõem um fundo comum, de modo que o oportunismo de um sobrecarregará a poupança coletiva, e o beneficiado auferirá ganhos indevidos deste contrato usufruindo do efeito carona.
} 
equilíbrio das carteiras. ${ }^{550}$ Por isso, a exigência da mais estrita boa-fé e veracidade persiste durante a execução do contrato.

Para manter o equilíbrio na sua atividade, o segurador deve determinar o limite de riscos cuja cobertura pode assumir. Para tanto estabelece, com base no balanço semestral, seu limite operacional, ou seja, o máximo de responsabilidade que pode assumir por ramo, e, com base neste, o limite técnico, que corresponde ao máximo de responsabilidade que pode assumir por risco isolado. Se determinada operação de seguro ultrapassar o limite técnico, isto é, a capacidade de subscrição do segurador, ele deverá recorrer ao cosseguro $^{551}$ ou resseguro ${ }^{552}$, instrumentos distintos de repartição de riscos, para garantir a segurança de sua atividade.

Tanto os riscos recenseados como os interesses protegidos deverão ser $\operatorname{homogêneos}^{553}$, a fim de permitir um cálculo de probabilidades tão exato quanto possível. ${ }^{554}$ As estatísticas devem agrupar riscos da mesma natureza, classificados por categorias e subcategorias que atendam ao imperativo da homogeneidade. ${ }^{555}$

\footnotetext{
${ }^{550}$ As declarações de risco serão discutidas na abordagem do dever de informar no contrato de seguro.

${ }^{551}$ Cosseguro é a divisão da garantia de determinado risco entre várias seguradoras, cada qual cobrindo uma cota-parte dele, em valor fixo ou percentual no limite da subscrição integral. A lei brasileira não estabelece solidariedade passiva das seguradoras, mas determina que a apólice indique uma delas para representar as demais em juízo, o que não as impede de ingressarem na lide. MELLO FRANCO, Vera Helena de. Breves reflexões sobre o contrato de seguro no novo Código Civil brasileiro. In: FÓRUM DE DIREITO DO SEGURO JOSÉ SOLLERO FILHO. ESTUDOS DE DIREITO DO SEGURO, São Paulo: IBDS-EMTS, 2002. p. 445-446.

${ }^{552}$ Resseguro é a operação pela qual o segurador, único responsável em relação a seus segurados pelos riscos que aceita, se garante, por sua vez, com um ressegurador em relação a uma parte da totalidade dos riscos a que ele próprio está sujeito. Mediante a transferência dessa parte dos riscos para o ressegurador, a seguradora poderá evitar que eventuais desvios que possam acarretar a insuficiência do fundo comum, formado pelo conjunto de prêmios. É, pois, o seguro do segurador. MELLO FRANCO, Vera Helena de. Lições de direito securitário: seguros terrestres privados, cit., p. 123-124. O objeto do contrato de resseguro não são aqueles riscos assumidos pelo segurador perante seus segurados, mas os inerentes ao desenvolvimento da própria atividade securitária. Como define Paulo L. Toledo Piza, resseguro é "instrumento empregado para a satisfação da necessidade da indústria securitária, contra os desequilíbrios atuariais que a podem afetar." PIZA, Paulo Luiz de Toledo. Contrato de resseguro: tipologia, formação e direito internacional. São Paulo: IBDS, 2002. p. 270.

${ }^{553}$ Adverte Lambert-Faivre, o imperativo de homogeneidade dos riscos se impõe ao segurador num plano especial, o do valor do risco garantido: se entre os riscos cobertos, um tem valor consideravelmente mais alto que os outros, e que é precisamente este risco elevado atingido por sinistro, o equilíbrio financeiro da mutualidade se rompe. LAMBERT-FAIVRE, Yvonne. op. cit., p. 37-38.

${ }^{554}$ Observa Lambert-Faivre que os riscos novos, recenseados em estatísticas insuficientes não permitem estabelecer com precisão um cálculo de probabilidade. Apesar disso, por razões comerciais, os seguradores garantem às vezes tais riscos, calculando, então, seus prêmios com larga margem de segurança, e atualizando constantemente suas estatísticas. Pode-se citar o seguro da responsabilidade por veículos terrestres motorizados no começo da expansão dos automóveis, ou atualmente o risco atômico pacífico, como exemplos desse dinamismo comercial do seguro. Id. Ibid., p. 36.

${ }^{555}$ LAMBERT-FAIVRE, Yvonne. op. cit., p. 36. A autora adverte que certos riscos não são tecnicamente suscetíveis de cobertura, porque sua realização maciça romperá o equilíbrio da mutualidade. Estes são os cataclismas naturais, tais como os maremotos, os terremotos que se repetem constantemente nas mesmas regiões, é também o risco de guerra provocando devastações generalizadas demais para serem garantidas. A
} 
Nem todo risco é suscetível de cobertura securitária. Via de regra, são seguráveis os riscos estáticos, individuais e puros. ${ }^{556}$ Estáticos são aqueles que implicam perdas não relacionadas a alterações macro-econômicas. Podem referir-se a perda ou perecimento de ativo patrimonial, em função de acidentes ou de ação intencional como furto ou roubo. Como ocorrem com alguma regularidade, podem ser estatisticamente processados. Para serem seguráveis, os riscos não devem afetar um número indeterminado de pessoas, mas devem ser individualizados. ${ }^{557}$ Puro é o risco que só envolve possibilidade de perda, e não de ganho.

A análise da base técnico-econômica da complexa operação de seguros, revela a imprescindibilidade da contratação de massa para viabilizá-la, o rigor de seus fundamentos científicos e o tratamento atuarial dos dados necessários à previsão de seus custos e do preço da garantia, indicando a necessidade de disciplinar a informação que permeia tais contratos e a aplicação intransigente do dever de informar em relação a ambas as partes. À seguradora, em razão de sua superioridade técnica no que concerne à matéria contratual, e ao segurado, em função das informações indispensáveis à organização da mutualidade que ele tem e que deve comunicar à contraparte.

cobertura de tais fragelos não incumbe às seguradoras, mas ao Estado ou à comunidade internacional (ajuda mútua internacional em caso de cataclismas excepcionais, danos decorrentes de guerra). Id. Ibid., p. 38-39.

${ }^{556}$ Classificações de riscos: Estáticos e Dinâmicos. Fundamentais e Individuais. Puros e Especulativos. (a) Estáticos são os riscos que implicam perdas dissociadas de mudanças na economia. Envolvem a destruição de um ativo patrimonial ou a alteração de sua titularidade resultante de ação humana intencional ou culposa. São suscetíveis de serem segurados por serem mais previsíveis e ocorrerem com certa regularidade. Dinâmicos são os riscos associados a mudanças econômicas, como, por exemplo, alterações nos preços ou mudanças nas preferências dos consumidores. Em geral, não são seguráveis, devido à sua maior imprevisibilidade e irregularidade. (b) Fundamentais são os riscos que envolvem perdas impessoais tanto na sua origem como nos seus efeitos. Afetam simultaneamente grande número de pessoas ou até toda a população. São causados por fenômenos econômicos, sociais e políticos, embora também possam resultar de eventos físicos. Desemprego, guerra, inflação, terremotos, enchentes pertencem a esta classe. Individuais são os riscos que envolvem perdas derivadas de eventos que afetam uma pessoa ou organização ou um ativo de seu patrimônio, como o incêndio de uma casa ou o roubo de um banco. Podem ser estáticos ou dinâmicos. A distinção entre estes dois tipos depende, em última instância, da opinião pública no que concerne à responsabilidade pelas causas e consequências dos riscos, como observam Emmet e Therese Vaughan. (c) Risco especulativo descreve uma situação em que existe tanto a possibilidade de perda como de ganho. Por isso, os riscos especulativos são voluntariamente criados ou, pelo menos, aceitos. O jogo é um bom exemplo de risco especulativo. No mercado de ações também se assumem riscos dessa natureza. Risco puro designa situações que envolvem a possibilidade de alguma ou nenhuma perda. A importância da distinção entre risco puro e especulativo é que geralmente só os riscos puros são seguráveis. O seguro não tem por objeto a proteção de interesses relacionados a riscos especulativos. VAUGHAN, Emmett J.; VAUGHAN, Therese M. op. cit., p. 5-7.

${ }^{557}$ Comentam os autores que, depois dos ataques terroristas de 11 de setembro 2001, as resseguradoras anunciaram a intenção de excluir riscos decorrentes de ataques terroristas da cobertura oferecida às seguradoras. Diante da anunciada perda da cobertura do resseguro, as seguradoras também desenvolveram políticas de exclusão de riscos decorrentes de terrorismo. Por isso, o Congresso americano instituiu um programa federal de resseguro contra terrorismo, em novembro de 2002. Este programa, contudo, estava previsto para expirar em 2007. Id. Ibid., p. 6. Os riscos fundamentais, quando comportarem cobertura, não devem ser impostos ao setor privado, pois são responsabilidade do Estado. 


\section{Aspecto social da operação de seguros}

Vista por este ângulo, destaca-se seu caráter previdenciário $e$ o cunho solidarístico $^{558}$. Na raiz do seguro está a ideia de previdência, que inspira as providências para prevenir ou mitigar os efeitos negativos dos riscos a que estamos expostos, e assistência mútua, pois se constatou que era mais fácil suportá-los coletivamente ${ }^{559}$. A união de indivíduos desconhecidos com finalidade de assistência recíproca, como meio de atenuar ou anular efeitos dos riscos que seriam individualmente insuportáveis, para tornálos coletivamente suportáveis, é a mais perfeita expressão de solidariedade. ${ }^{560}$ É fácil inferir desta assertiva a importância da disciplina da informação em relações jurídicas caracterizadas pela impessoalidade e solidariedade, que têm por objeto a prestação de garantias recíprocas.

Destacando a crescente importância social do seguro, Kenneth Abraham afirma que o instituto funciona como elemento equalizador, transferindo recursos dos que têm sorte para os que não têm ${ }^{561}$.

As funções social e econômica do seguro podem, todavia, ser consideradas faces da mesma moeda, porque, via de regra, fatores redutores de incerteza tendem a incentivar a economia, o que favorece o bem-estar coletivo. Daí a adequação de sua abordagem conjunta. Mas analisar o papel do seguro na sociedade implica discutir como as pessoas reagem ao risco para compreender todo o significado social e econômico da garantia propiciada pelo seguro.

\section{Reações à percepção do risco}

O risco afeta diferentemente as pessoas, de acordo com as circunstâncias de cada uma delas. E as reações às situações que o envolvem são diferentes não só de um indivíduo para outro, mas de uma situação para outra, mesmo se tratando da mesma pessoa.

Existem agentes neutros em relação ao risco, que o vêem como equivalente ao seu valor esperado, resultante da multiplicação do montante de eventual perda (ou ganho) pela

\footnotetext{
${ }^{558}$ MELLO FRANCO, Vera Helena de. Contratos: direito civil e empresarial, cit., p. 19.

${ }^{559}$ ALVIM, Pedro. O contrato de seguro. 3. ed. Rio de Janeiro: Forense, 1999. p. 1-2.

${ }^{560}$ Observe-se, porém, que o aspecto social é indissociável do econômico, pois a solidariedade de pouco adiantaria se não fosse a estrutura técnica do seguro, fundada em matemática atuarial e estatística, que evita que os riscos sejam simplesmente transferidos ao segurador, mas permite sua pulverização, assegurando melhor a garantia de cobertura.

${ }^{561}$ ABRAHAM, Kenneth. Insurance law and regulation. 4. ed. New York: Foundation Press, 2005. p. 4-5.
} 
probabilidade de sua ocorrência. Exemplo: perda possível (100.000) x probabilidade de ocorrência $(1 \%)=100$ (valor esperado)

A tendência mais comum, no entanto, é a aversão ao risco. Assim, pessoas geralmente preferem pagar uma quantia menor e certa no presente para não ter que dispor de outra maior e incerta no futuro. Essas pessoas não consideram apenas o valor esperado das perdas, mas levam em conta também a sua magnitude, como observa Steven Shavell, argumentando que, para tais indivíduos, o risco de 5\% de perda de $\$ 20.000$ é pior do que a possibilidade de $10 \%$ de perda de $\$ 10.000$, embora ambas as situações correspondam à mesma expectativa de perda de $\$ 1.000$.

Nas mesmas circunstâncias, agentes neutros em relação ao risco considerariam as duas situações equivalentes. E os que não se arriscam escolheriam uma terceira opção, que seria pagar antecipadamente a quantia certa de 1.000, para afastar qualquer possibilidade de perda futura. Dependendo do grau de aversão, eles aceitariam pagar mais do que o valor esperado $^{562}$ para aliviar a sensação provocada pelo risco, pois temem a incerteza pura e simples, e atentam para o montante da perda independentemente do grau de possibilidade de sua ocorrência. ${ }^{563}$

A aversão ao risco, segundo Shavell, é consequiência da diminuição da utilidade marginal da riqueza. ${ }^{564}$ Explicando tal constatação, Avery Katz argumenta que, como os agentes racionais observam uma ordem de preferência na satisfação de suas necessidades materiais, eles obtêm proporcionalmente menos valor dos incrementos adicionais de dinheiro. Por isso, a porção inferior do prospecto de risco, que ameaça com perda de necessidades relativas, tem mais peso do que a porção superior, que promete ganho de mais luxos relativos. ${ }^{565}$ Embora a utilidade do agente cresça na medida do aumento de sua riqueza, este aumento ocorre em grau decrescente. Presumindo que o agente avalia a prospecção de risco medindo seus efeitos sobre sua utilidade esperada, conclui que ele não se disporá a suportar o risco de grandes perdas, que representarão menor utilidade. A utilidade esperada resulta da multiplicação da utilidade de cada consequência possível por sua probabilidade.

\footnotetext{
${ }^{562}$ FRIEDMAN, David. Law's order: what economics has to do with law and why it matters. New Jersey: Princeton University Press, 2000. p. 63-64.

${ }^{563}$ SHAVELL, Steven. The allocation of risk and the theory of insurance. In: Economic analysis of accident law. Cambridge: Harvard University Press, 1987. p. 186-199.

${ }^{564}$ Id., loc. cit.

${ }^{565}$ KATZ, Avery W. Foundations of economic analysis of law. New York: Foundation Press, 1998. p. 208-209.
} 
Segundo Shavell, cálculos demonstram que a utilidade esperada será menor se a parte enfrentar 5\% de probabilidade de uma perda de $\$ 20.000$, do que se ele encarasse $10 \%$ de probabilidade de uma perda de $\$ 10.000$, porque um prejuízo de $\$ 20.000$ representará mais de duas vezes a diminuição de utilidade do que a decorrente de uma perda de $\$ 10.000 .^{566}$

Outro aspecto, salientado por Knight, concerne à crença inveterada das pessoas de confiarem na própria sorte, principalmente quando está em jogo a possibilidade de ganho, tanto que as pessoas estão geralmente dispostas a arriscar uma pequena quantia na esperança de ganhar outra maior, mesmo quando as probabilidades são quase todas contrárias, mas não trocarão pequena probabilidade de perder uma quantia grande por certeza virtual de ganhar uma pequena, mesmo que o valor atuarial da probabilidade esteja a seu favor ${ }^{567}$.

Como observamos, o grau de aversão ao risco dependerá não só da magnitude da perda em termos absolutos, mas da dimensão desta em relação ao patrimônio e das necessidades de cada indivíduo. Sua variação depende, portanto, da ponderação entre os possíveis resultados futuros e as circunstâncias presentes. David Friedman ilustra essa asserção, concluindo que tal aversão concerne mais a resultados do que a riscos. As pessoas adquirem seguro mesmo sabendo que, na média, a probabilidade é que elas ganhem menos do que gastam com os prêmios, pois os segurados avaliam essa aquisição com base em outros parâmetros, não mensurados pelo valor unitário do dinheiro, mas pelo valor que o dinheiro representaria na hipótese de concretização do risco. Ele concorda com Avery Katz que, neste caso, a base da escolha dos agentes é a diminuição da utilidade marginal. Assevera que a aversão a risco não concerne propriamente à maior ou menor atração das pessoas pelo risco, mas diz respeito à variação do valor do dinheiro dependendo do quanto o indivíduo tem. Por isso, a aversão não seria exatamente ao risco, mas à perda financeira ${ }^{568}$.

O impacto do risco sobre as pessoas é, portanto, representado pela possibilidade de perda. Essas perdas são a razão primordial pela qual os indivíduos tentam evitar riscos ou aliviar o peso de seus efeitos ${ }^{569}$.

\footnotetext{
${ }^{566}$ SHAVELL, Steven. The allocation of risk and the theory of insurance, cit., p. 186-199.

${ }^{567}$ KNIGHT, Frank Hyneman. op. cit., p. 235-236.

${ }^{568}$ Só isso explicaria a atitude do indivíduo que compra seguro quando viaja de avião, mas pratica paraquedismo por hobby. FRIEDMAN, David. op. cit., p. 64-65.

${ }^{569}$ VAUGHAN, Emmett J.; VAUGHAN, Therese M. op. cit., p. 8.
} 
Mas não é só a possibilidade de perda financeira que provoca reações ao risco. Outro efeito deletério que se tenta elidir ou, pelo menos, controlar é a sensação de insegurança que o acompanha e provoca inquietação, especialmente em se tratando de risco puro, em que não há expectativa de ganho ${ }^{570}$. Este efeito psicológico da incerteza sobre o indivíduo acaba se refletindo na sociedade, porque a falta de confiança do agente o compelirá a guardar recursos para contingências em vez de investi-los em atividades social e economicamente mais úteis. ${ }^{571}$ Aqui reside uma das mais importantes funções do seguro.

\section{Função sócio-econômica da operação de seguro}

As reações de aversão ao risco comprovam que sua distribuição afeta o bem-estar social, porque a redução da utilidade esperada em razão da assunção de riscos é maior em relação aos agentes que mais o temem. Por isso, o deslocamento dos efeitos patrimoniais do risco para os que lhe têm menos aversão representa um benefício à sociedade. ${ }^{572}$ Esta solução corresponde ao ideal de eficiência paretiana, pois se aqueles pagarem a estes pela assunção dos riscos ou de seus efeitos patrimoniais, todos ganham ${ }^{573}$.

O bem-estar social aumenta não só com a redistribuição dos riscos dos mais avessos aos mais neutros, como entre os avessos, pois compartilhar riscos reduz a magnitude da eventual perda que qualquer um deles pudesse sofrer. Por isso, Shavell observa que, mesmo a repartição desigual pode ser benéfica, se os envolvidos tiverem diferentes graus de aversão a risco. E conclui que, aumentar o número de participantes nessa distribuição melhora, em tese, o bem-estar social, porque tende a reduzir mais o volume de perdas individuais. ${ }^{574}$ Essa é, pois, outra contribuição do seguro para a sociedade.

A proteção dos agentes avessos a risco é socialmente benéfica por razões bem distintas daquelas que invocam a equidade na distribuição de riqueza, pois mesmo se tratando de dois indivíduos avessos a risco e com igual nível de riqueza, em relação aos

\footnotetext{
${ }^{570}$ VAUGHAN, Emmett J.; VAUGHAN, Therese M. op. cit., p. 8.

${ }^{571}$ A já referida observação de Luhman de que a confiança traz o futuro para o presente também tem esta conotação. Vide Cap. 3, nota 257.

${ }^{572}$ SHAVELL, Steven. The allocation of risk and the theory of insurance, cit., p. 186-199.

${ }^{573} \mathrm{O}$ modelo de eficiência de Vilfrido Pareto corresponde à situação que não comporta mais alteração sem que ninguém fique pior, ou seja, ninguém pode aumentar seu bem-estar sem reduzir o bem-estar de outrem. Esse é o equilíbrio que o seguro proporciona.

${ }^{574}$ SHAVELL, Steven. The allocation of risk and the theory of insurance, cit., p. 186-199.
} 
quais não se cogita de problemas de justiça distributiva, ambos ficarão em situação melhor, se partilharem riscos. ${ }^{575}$

O aumento do bem-estar social promovido pela adequada distribuição de riscos se deve não só à redução dos efeitos suportados pelos que mais o temem, mas também por reverter os recursos eventualmente destinados à assunção de riscos a outras atividades socialmente mais produtivas. 576577

É evidente a utilidade social do mercado para deslocamento de riscos e Arrow a explica de maneira muito simples: se um agente teme mais a incerteza e acha outro para quem o custo de assumir o risco é menor, ambos se beneficiam da troca pela qual este assume o risco contra o pagamento de um prêmio fixo. E aponta que, se o contrato beneficia as partes contratantes sem prejudicar terceiros, também beneficia a sociedade, que "é apenas um rótulo convencional para a totalidade de indivíduos". 578

Temendo eventuais sinistros, as pessoas contratam seguro a fim de não se exporem a circunstâncias que poderão torná-los dependentes da sociedade, e em relação a danos causados a terceiros, como forma de evitar prejuízos a seu patrimônio ${ }^{579}$. Os seguros de pessoas, como os de vida e de saúde, análogos aos da previdência social, atendem com mais eficiência à necessidade das pessoas, que optarão por eles se puderem arcar com os respectivos ônus. E, nos casos em que seguros privados não podem substituir integralmente o sistema estatal, operam como complementos deste.

O seguro representa papel relevante do ponto de vista social, não só associado à previdência pública, mas também como sistema privado de responsabilidade civil, assumindo funções originariamente do Estado, com o que acaba desonerando os cofres públicos. Por isso, é importante que a regulação não crie custos de transação adicionais.

É estreita a relação de dependência e complementaridade entre os institutos do seguro e da responsabilidade civil ${ }^{580}$, no ponto em que se interceptam, que é o referente ao ramo de danos e à responsabilidade civil. Porém, apesar de se complementarem, estão em permanente tensão principalmente em razão do fenômeno do moral hazard, já discutido

\footnotetext{
${ }^{575}$ SHAVELL, Steven. The allocation of risk and the theory of insurance, cit., p. 186-199.

${ }^{576}$ Id., loc. cit.

${ }^{577}$ ARROW, Kenneth. Insurance, risk and resource allocation. Reimpr. de Aspects of the theory of risk bearing. MA: Belknap Press Harvard University, 1984. p. 81. (Collected Papers of Kenneth Arrow, v. 4, Economics of Information).

${ }^{578}$ Id. Ibid., p. 80-81.

${ }^{579}$ PICARD, Maurice; BESSON, André. op. cit., p. 10-11.

${ }^{580}$ Embora também alcance a responsabilidade criminal, nos casos em que a conduta causadora do dano se subsume a tipo penal, pois são instrumentos de administração de riscos.
} 
anteriormente, e inerente às relações de seguro, caracterizadas pela assimetria informacional, que impede o segurador de monitorar as ações do segurado.

Os objetivos da responsabilidade civil não se restringem à reparação de danos, mas focalizam principalmente a prevenção. $\mathrm{O}$ estudo da responsabilidade civil, sistematizado por Calabresi ${ }^{581}$, constatou que os danos geram, além dos custos primários, atinentes ao valor total dos prejuízos sofridos pela vítima, dos danos materiais e morais aos lucros cessantes, outros que nem sempre são levados em consideração. São os custos secundários, correspondentes à dispersão dos riscos e demais implicações da operação securitária; e $o s$ custos terciários, relacionados à administração dos primários e secundários, como serviços de socorro, a investigação policial e a do seguro, os custos do eventual processo civil e penal. O objetivo das regras de responsabilidade civil é evitar ou reduzir tais custos, porque os recursos neles empenhados seriam mais eficientemente utilizados para outros fins, maximizando o bem-estar coletivo. Portanto, a função precípua das regras de responsabilidade civil estimular diligência e precaução na conduta dos agentes, além, obviamente, de prover reparação às vítimas de atos ilícitos.

Por outro lado, embora o seguro não provoque a transferência de risco, pois só seus efeitos são tratados pela seguradora, o fato é que, contratado o seguro, o segurado não percebe mais o risco como seu, e passa a cuidar do interesse protegido pelo seguro, como coisa alheia, ou seja, com menos zelo e diligência. Esta negligência consciente, tão comum, é conhecida como moral hazard. Eventualmente a conduta do segurado extrapola a culpa, quando ele age intencionalmente contra normas de precaução, como dirigir embriagado, por exemplo, caracterizando forma agravada de moral hazard. Em outras palavras, a externalização dos custos decorrentes da realização dos riscos incentiva a redução de precaução na prevenção de acidentes, desafiando o objetivo do instituto da responsabilidade civil, e fazendo com que o seguro paradoxalmente provoque efeito contrário a um de seus objetivos, que seria reduzir efeitos dos sinistros.

Funcionando como um sistema privado de responsabilidade civil, o seguro de danos aloca contratualmente o custo de acidentes, e estabelece regras próprias de segurança, privatizando a responsabilidade e disciplinando o grau de precaução dos agentes. ${ }^{582} \mathrm{Em}$ razão dessa estreita co-relação que o seguro de danos guarda com a responsabilidade civil, as regras do seguro afetam a eficiência da disciplina jurídica da responsabilidade. Para

\footnotetext{
${ }^{581}$ CALABRESI, Guido. The costs of accidents, a legal and economic analysis. New Haven: Yale University Press, 1970.

${ }^{582}$ COOTER, R.; ULEN, T. op. cit., p. 355.
} 
evitar esta externalidade gerada pelo seguro, é indispensável aplicar com mais rigor as normas destinadas a coibir o moral hazard, especialmente as referentes ao agravamento do risco, de forma a ilidir comportamentos mais que oportunistas, até predatórios. A condescendência com o agravamento do risco segurado acaba produzindo externalidades negativas, extrapolando as lindes das relações individuais, atingindo a coletividade de segurados e repercutindo no âmbito da responsabilidade civil. A avalanche de acidentes de trânsito com consequências graves decorre, em larga medida da falta de percepção desse problema e do tratamento rigoroso que ele merece do aplicador da lei. Isso tudo, de certa forma, está relacionado à disciplina da informação no contrato de seguro. ${ }^{583}$

É unânime na literatura especializada o consenso sobre a utilidade social do seguro, que, distribuindo e diluindo riscos na mutualidade, promove bem-estar social ${ }^{584}$. Alguns o vêem como meio de transferência de riscos ${ }^{585}$. Mas, transferência é expressão inadequada, porque "o seguro apenas garante que, ocorrendo o evento, o sinistro, as perdas serão compostas, total ou parcialmente, dependendo da garantia prestada." 586

O seguro promove a segurança por meio da solidariedade, porque implica a prestação de garantias recíprocas e responde a uma necessidade incontestável do

\footnotetext{
${ }^{583}$ A questão do agravamento do risco será examinada oportunamente.

${ }^{584}$ ARROW, Kenneth. Insurance, risk and resource allocation. Reimpr. de Aspects of the theory of risk bearing, cit., p. 79. Arrow cita o mercado acionário como outra instituição eficiente na repartição de riscos, porque também reduz o ônus social da sua assunção, embora não os processe da mesma forma que o seguro.

${ }^{585}$ Embora não se trate, a rigor, de transferência de risco, primeiro, porque este continua recaindo sobre o segurado, e segundo, porque o segurador não o assume, mas o dilui na mutualidade que organiza, autores norte-americanos invariavelmente fazem menção à transferência e deslocamento, ou à assunção de risco pela seguradora, e tais expressões têm sido assim traduzidas e transcritas por fidelidade ao original. Eles vislumbram transferência de riscos na contratação do seguro, o que não significa, porém, desconhecimento do mecanismo do instituto. Pelo teor de seus textos depreende-se que usam a figura da metonímia, tropo que consiste em designar um objeto por palavra designativa de outro que tem com o primeiro alguma relação, como, por exemplo, de causa e efeito, ou de continente e conteúdo, etc. E essa figura se aplica perfeitamente ao caso, porque se diz transferência de risco, referindo-se a seus efeitos patrimoniais. Além disso, autores como Emmet e Therese Vaughan discutem se a função do seguro é de transferência ou dispersão de riscos a partir de dois pontos de vista: o individual e o social. Do primeiro aspecto, sustentam que o seguro é um meio pelo qual o indivíduo substitui um pequeno e certo custo por uma grande e incerta perda, o que enfatiza a função de transferência do risco, ou melhor, de seus efeitos. Da perspectiva social, argumentam que o seguro é um instrumento econômico de redução e eliminação de risco por meio de um processo de combinação de um número suficiente de exposições homogêneas num grupo de segurados, de modo a tornar as perdas previsíveis, o que denota a função de dispersão. Estes autores argumentam que, a despeito da técnica de diluição de riscos na mutualidade, a função essencial do seguro é transferir riscos do indivíduo para o grupo. VAUGHAN, Emmett J.; VAUGHAN, Therese M. op. cit., p. 41-42. Explicando como funciona o seguro, Kenneth Abraham aponta a transferência de risco como a primeira etapa da operação securitária: o agente mais avesso a risco o transfere ao mais neutro, que o processa e dilui pelo mecanismo da operação técnica. ABRAHAM, Kenneth. op. cit., p. 3-4. Isso, porém, não nos parece convincente, porque o segurador só aceita prestar a garantia porque não assume o respectivo risco, mas ao calculá-lo já considera sua distribuição na mutualidade.

${ }^{586}$ SZTAJN, Rachel. Sistema financeiro, cit., p. 63.
} 
homem, ${ }^{587}$ que, isolado, se torna muito vulnerável aos golpes do destino, que o mantém num estado de sofrível insegurança moral e econômica. ${ }^{588}$ A possibilidade de externalizar eventuais danos patrimoniais provenientes da materialização de riscos, diluindo-os entre inúmeros outros agentes, e assegurando a cada um deles a recomposição patrimonial em caso de sinistro, faz com que todos busquem se garantir por meio do seguro, porque é evidente a vantagem de poder evitar um possível e imprevisível custo alto, mediante um baixo custo fixo. A garantia mútua, pela qual o grupo de segurados se compromete a arcar com as consequências danosas de evento contratualmente previsto, que afete qualquer um de seus integrantes, expressa solidariedade e previdência, e resulta na segurança patrimonial dos segurados, que assim poderão assumir mais compromissos e buscar novos empreendimentos.

Se, desde sua forma pré-embrionária de simples repartição de riscos, o seguro já funcionava como fator de proteção patrimonial e indutor da atividade mercantil e do desenvolvimento, com mais razão, na sua versão atual e diante do contexto global, que propicia crescente insegurança.

A abordagem das funções do seguro evidencia o amplo espectro de sua aplicação, abrangido por seus dois grandes ramos, de seguros pessoais e de danos. ${ }^{589}$

Em suma, o seguro é instrumento de grande utilidade social e econômica, e será tanto mais eficiente se, na aplicação da lei, forem observadas suas peculiaridades técnicas. Os aspectos sociais e econômicos do seguro são indissociáveis de seu arcabouço jurídico.

\section{Aspecto jurídico do seguro}

Na legislação brasileira, o contrato de seguro é aquele pelo qual o segurador se obriga, mediante o pagamento do prêmio, a garantir interesse legítimo do segurado, relativo a pessoa ou a coisa, contra riscos predeterminados ${ }^{590}$.

A definição legal apresenta com clareza os elementos essenciais do instituto, interesse exposto a risco, garantia e prêmio, não deixando, porém, entrever uma de suas

\footnotetext{
${ }^{587}$ PICARD, Maurice; BESSON, André. op. cit., p. 11.

${ }^{588}$ LAMBERT-FAIVRE, Yvonne. op. cit., p. 33.

${ }^{589}$ Não abordamos neste trabalho cada um dos ramos, em razão da impertinência, dada a especificidade do tema aqui tratado.

${ }^{590}$ Art. 757 CC.
} 
características principais, a reciprocidade da garantia, ou a mutualidade, sem a qual não se tem noção da operação subjacente e da verdadeira essência do instituto.

A doutrina nacional e a estrangeira não fazem menção ao aspecto econômico ao conceituarem o contrato de seguro.

Pontes de Miranda define o seguro como "o contrato com que um dos contraentes, o segurador, mediante prestação única ou periódica, que o outro contraente faz, se vincula a segurar, isto é, se o sinistro ocorrer, entregar ao outro contraente soma determinada ou determinável, que corresponde ao valor do que foi destruído, ou danificado, ou que se fixou para o caso do evento previsto". 591

Para Pedro Alvim o contrato de seguro é aquele "pelo qual o segurador, mediante o recebimento de um prêmio, obriga-se a pagar ao segurado uma prestação, se ocorrer o risco a que está exposto". 592

Vivante aponta a atividade empresarial do segurador, como elemento necessário do seguro, por ele definido como "contrato pelo qual uma empresa constituída para o exercício desta atividade assume risco alheio mediante pagamento de prêmio préfixado". 593

A definição de Rubén Stiglitz destaca o aspecto de adesão: contrato por adesão pelo qual uma das partes, o segurador, se obriga, mediante o pagamento ou promessa de pagamento do prêmio pelo segurado, a pagar a este ou a um terceiro a prestação convencionada, subordinada à eventual realização de um risco (sinistro), tal como tenha sido determinado, no curso de duração do contrato. ${ }^{594} \mathrm{O}$ autor sustenta que a definição jurídica deve excluir fundamentos técnicos do seguro. Mas não faz sentido excluí-los, se a doutrina é unânime em reconhecer que a mutualidade - aspecto técnico - é a essência da operação securitária. Se a utilidade da definição é identificar as características do instituto, traçando seus limites, para determinar o regime jurídico a que estaria sujeito, para que serviria uma definição que desconsidera os traços mais marcantes da operação econômica subjacente, diretamente ligados à função do instituto?

\footnotetext{
${ }^{591}$ PONTES DE MIRANDA, F. C. Tratado de direito privado: parte especial. 3. ed. São Paulo: Ed. Revista dos Tribunais, 1984. t. 45, p. 274-275.

${ }^{592}$ ALVIM, Pedro. op. cit., p. 113.

${ }^{593}$ VIVANTE, Cesare. Del contratto di assicurazione. Torino: Unione Tipografico - Editrice Torinese, 1936. p. 26.

${ }^{594}$ STIGLITZ, Rubén S. Derecho de seguros, cit., p. 31.
} 
Tratando do conceito econômico do seguro, Garrigues sublinha a importância de sua característica essencial, concluindo enfaticamente com a expressão de Stein: 'seguro es mutualidad o no es seguro, ${ }^{595}$. No entanto, conceitua o instituto como contrato substantivo e oneroso pelo qual uma pessoa, o segurador, assume o risco da ocorrência de evento incerto, pelo menos em relação ao tempo, obrigando-se a pagar ao segurado uma prestação pecuniária quando o risco se converter em sinistro. ${ }^{596}$

Picard e Besson resumem o seguro como a operação pela qual o segurador se compromete a pagar ao segurado, mediante remuneração (prêmio), uma prestação no caso da realização de um risco. ${ }^{597}$

Tem sido impossível à doutrina conciliar a perspectiva econômica e a jurídica num só conceito. Tanto que autores têm apresentado duas definições, ${ }^{598}$ como se descrevessem fenômenos diferentes. O problema é que a estrutura jurídica não corresponde à função econômica e seus aspectos técnicos. Fica, por isso, a impressão de que, embora o contrato seja a veste jurídica da operação econômica subjacente, não lhe serve bem, no caso do seguro.

Daí a perplexidade dos intérpretes e dos aplicadores da lei diante de algumas peculiaridades do seguro, que não transparecem se considerado apenas o aspecto jurídico do instituto. Algumas distorções decorrem da análise unifocal do seguro, que indica a bilateralidade da simples troca de um dado valor por uma garantia, não evidenciando a mutualidade.

Mas, ainda que a feição jurídica do seguro não permita visualizar a operação subjacente que reveste, a lei reconhece implicitamente algumas idiossincrasias do instituto, como a assimetria informacional e a necessidade de aplainá-la, estabelecendo o dever de máxima boa-fé e veracidade.

\footnotetext{
${ }^{595}$ GARRIGUES, Joaquín. Contrato de seguro terrestre. Madrid: La Ley, 1973. p. 35-36

${ }^{596}$ Id. Ibid., p. 39. O termo substantivo não faz sentido na definição, tanto que Ruben Stiglitz o atribui a um erro material, supondo, pelo contexto que Garrigues pretendera dizer substitutivo de prestações, significando bilateral. STIGLITZ, Rubén S. Derecho de seguros, cit., p. 31.

${ }^{597}$ Tradução livre de: «une opération par laquelle une partie, l'assuré, se fait promettre moyennant une rémunération, la prime, une prestation par une autre partie, l'assureur, en cas de réalisation d'un risque». PICARD, Maurice; BESSON, André. op. cit.

${ }^{598}$ LAMBERT-FAIVRE: Définition juridique: envisagée dans les relations bilatérales assurer-assuré, "l'assurance est le contrat par lequel une partie, l'assuré, se fait promettre par une autre partie, l'assureur, une prestation en cas de réalisation d'un risque, moyennant le paiement d'un prix, appelé prime ou cotisation». Définition technique: Sous son aspect technique que est fondamental, "l'assurance est l'opération par laquelle un assureur, organisant en mutualité une multitude d'assurés exposés à la réalisation de certains risques, indemnise ceux d'entre eux qui subissent un sinistre grâce à la masse commune des primes collectés». LAMBERT-FAIVRE, Yvonne. op. cit., p. 32.
} 
Em todo o mundo jurídico ocidental se destaca a uberrima fides como característica essencial ou princípio regente do contrato de seguro. Como já tratamos da estreita relação entre boa-fé e informação, basta apontar que a razão da imposição do princípio se prende ao aspecto técnico da operação securitária, que depende dos dados informados pelos segurados para processar o tratamento do risco, avaliando-o e classificando-o para, só então, fixar o prêmio.

Mas a imposição da máxima boa-fé também revela preocupação da lei com a mutualidade, pois a exigência de transparência e veracidade também funciona como proteção do fundo mútuo. As omissões e distorções dos segurados provocam efeitos negativos $^{599}$ que extrapolam a relação bilateral com o segurador, e atingem o fundo de recursos comuns.

\section{Características do contrato de seguro}

A aplicação do dever de informar ao contrato de seguro pressupõe o conhecimento de características deste. O interesse da classificação dos contratos serve, em tese, à sua subsunção a determinada disciplina jurídica, de acordo com a categoria a que pertencem. Da classificação dos institutos se deveria, pois, poder inferir sua regência.

A doutrina classifica o contrato de seguro como bilateral, oneroso, consensual, de adesão, e ainda há dissidência em relação à sua aleatoriedade ou comutatividade.

\section{Bilateralidade}

Como o contrato de seguro prevê obrigações para ambas as partes, é considerado bilateral. As obrigações principais dos contratantes são o pagamento do prêmio pelo segurado, e, em contrapartida, a prestação da garantia pelo segurador.

Entretanto, a bilateralidade do contrato de seguro só pode ser concebida como abstração, já que este tipo contratual não pode, a rigor, ser considerado isoladamente. Como os riscos só são tratados coletivamente, não pode existir um contrato de seguro, por força de sua própria natureza, que implica contratação em massa para constituição da garantia mútua, e exige um feixe de contratos, transcendendo, por isso, a bilateralidade.

\footnotetext{
${ }^{599}$ Estes efeitos que se refletem sobre terceiros são as já referidas externalidades.
} 
Assim, a concepção de um contrato de seguro isolado é meramente ficcional, como se examinássemos somente a moldura jurídica, sem seu substrato econômico. Essa classificação, em vez de propiciar visão consentânea com a operação subjacente, contribui para distorcer a interpretação do instituto, como se o seguro se resumisse na bilateralidade da relação seguradosegurador. Os efeitos desta inadequação se manifestam na aplicação distorcida da lei, quando não são considerados os traços peculiares à feição econômica do contrato ${ }^{600}$.

Se a mutualidade é a pedra angular do instituto, que se traduz por garantia recíproca, isto permanece arraigado no seguro, mesmo quando administrado por instituição financeira. Sua essência subsiste, pois, como ponderava Ovídio Baptista ${ }^{601}$, "a forma de gestão não interfere e muito menos modifica a natureza do contrato de seguro." 602

Considerando a operação econômica subjacente ao contrato de seguro, a definição mais adequada seria relação comunitária ${ }^{603}$ pela qual se adere a um grupo cujos recursos são administrados pelo segurador, instituição financeira autorizada, que, com base no fundo mútuo por ela organizado, se compromete a arcar com eventual realização de risco predeterminado, mediante pagamento de prêmio prefixado. Esta conceituação permitiria entrever a mutualidade sob a moldura jurídica bilateral do instituto.

\section{Onerosidade}

Considera-se oneroso o contrato de seguro, pois compete ao segurado o pagamento do prêmio para obtenção da garantia a ser prestada pelo segurador. Importante reiterar que

\footnotetext{
${ }^{600}$ Fundamentos de decisões judiciais equivocadas frequentemente deixam entrever essa visão unifocal do contrato de seguro, que o analisa somente da perspectiva jurídica, levando em conta apenas a bilateralidade, que não permite inferir a função da mutualidade nesse tipo contratual.

${ }^{601}$ SILVA, Ovídio Baptista da. Relações jurídicas comunitárias e direito subjetivo. In: FÓRUM DE DIREITO DO SEGURO JOSÉ SOLLERO FILHO. ESTUDOS DE DIREITO DO SEGURO, 1. Anais... São Paulo: Max Limonad, 2000. p. 21-23.

${ }^{602}$ Tanto na modalidade associativa, sem finalidade lucrativa, em que os segurados figuram também como seguradores, como na modalidade empresarial, o contrato de seguro tem na mutualidade sua característica essencial, porque é inerente à sua natureza. A atividade empresarial da seguradora é administrar os riscos no tempo, mensurando-os, agrupando-os de acordo com seus fatores comuns (freqüência, severidade, etc), e pulverizando-os, para viabilizar a reparação dos riscos que se transformarem em sinistros, mediante prêmios fixos que formarão esse fundo mútuo, que será gerido pelo segurador.

${ }^{603}$ Para usar a expressão de Ovídio Batista. (v. nota 601 retro) Calmon Passos sustenta que o contrato de seguro é um negócio jurídico coletivo, integrado pelos muitos atos individuais que aportam para o fundo comum os recursos tecnicamente exigidos para a segurança de todos em relação às incertezas do futuro. A massa comum dos recursos financeiros a ninguém pertence, em termos de propriedade individual, sendo algo em aberto e permanentemente disponível para atender às necessidades que surjam e para cuja satisfação foi constituída "A atividade securitária e sua fronteira com os interesses transindividuais responsabilidade da SUSEP e competência da Justiça Federal, cit.
} 
a obrigação principal do segurador é a segurança do interesse protegido e não o pagamento da indenização pelo sinistro, que tem caráter eventual.

\section{Comutatividade}

Perante a legislação brasileira, é aleatório o contrato concernente a coisas ou fatos futuros, cujo risco de não virem a existir é assumido por um dos contratantes, sem que isso afete o direito de a outra parte receber integralmente a sua prestação, desde que não tenha contribuído com dolo ou culpa, e ainda que nada do avençado venha a existir. ${ }^{604}$ Distinguese do contrato condicional porque, neste, a eficácia é que depende de acontecimento futuro e incerto, enquanto, naquele, a incerteza concerne à extensão das vantagens visadas pelas partes, o risco está na alternativa de ganho ou perda. ${ }^{605}$

Persiste a dissidência entre doutrinadores quanto à natureza aleatória ou comutativa do contrato de seguro. Os adeptos da primeira corrente justificam essa posição com o argumento de que, considerado isoladamente como relação segurado-segurador, não se pode afastar a álea, que é pressuposto da operação securitária ${ }^{606}$.

No Brasil, também há muitos adeptos da tese da aleatoriedade. Entendendo que a assunção da álea é uma contraprestação do segurador, Pontes de Miranda afirma "a aleatoriedade existe mesmo se o evento é inevitável, como a morte: a álea, aqui, é no tempo, refere-se a quando e não a se. (...) Basta considerar-se a diferença do valor e do

\footnotetext{
${ }^{604}$ Art. 458 CC.

${ }^{605}$ GOMES, Orlando. Contratos. 26. ed. Coord. Edvaldo Brito. Atualizadores Antonio Junqueira de Azevedo e Francisco Paulo De Crescenzo Marino, Rio de Janeiro: Forense, 2009. p. 89.

${ }^{606}$ PLANIOL, Marcel; RIPERT, Georges. Traité pratique de droit civile français: contrats civils, deuxième partie. Paris: Librairie Générale de Droit et de Jurisprudence, 1932. t. 11, p. 555. PLANIOL, Marcel; RIPERT, Georges. Traité pratique de droit civile français: obligations, premième partie. Paris: Librairie Générale de Droit et de Jurisprudence, 1930. t. 6, p. 49. VIVANTE, Cesare. Del contratto di assicurazione, cit., p. 26. DONATI, Antigono. Trattato del diritto delle assicurazione private. Milano: Multa Pacis, 1952. v. 2, p. 40-41. "Claro es que, por consecuencia de la explotación en masa del seguro por las empresas aseguradoras, se suprime el 'álea' en el sentido de ventaja o desventaja para el asegurador, considerados en conjunto todos los contratos celebrados, porque las desventajas de unos contratos se compensan con las ventajas de otros, y la explotación total se hace sobre cálculos precisos. Pero considerado aisladamente cada contrato, también es aleatorio para el asegurador.” GARRIGUES, Joaquín. op. cit., p. 55; STIGLITZ, Rubén S. Derecho de seguros, cit., p. 190; HALPERIN, Isaac. op. cit., p. 25-27. No texto da legislação comentada pela doutrina italiana e com anotações jurisprudenciais, sob coordenação de ( $a$ cura di) Stefano Benini, também se sustenta a aleatoriedade. Opõe-se à tese que define a prestação do segurador como prestação de garantia, para a qual a incerteza do resultado seria eliminada pelo exercício da atividade securitária, através da organização de uma compensação de riscos, e a exclusão de aleatoriedade, argumentando que não se pode confundir o risco empresarial com a aleatoriedade de cada contrato. Acrescenta que a caracterização desse contrato como uberrimae fidei é enfatizada pela natureza aleatória do contrato. BENINI, Stefano. In: LA TORRE, Antonio (a cura di). Le assicurazioni. 2. ed. ampl. e agg. Milano: Giuffrè, 2007. p. 8-9.
} 
objeto das prestações que incumbem aos contraentes para se verificar que de ambos os lados há álea: um quer eliminá-la; outro, assumindo-a, eliminou-a porque a isso se vincula." 607

A corrente que defende a comutatividade do contrato de seguro ${ }^{608}$ justifica sua posição, argumentando que a prestação do segurador não é a indenização, elemento eventual do contrato, mas a garantia prestada desde o início da vigência contrato, contra o pagamento de um prêmio prefixado. Mesmo considerada a operação da perspectiva do segurado, não se trata de contrato aleatório, pois proteção tem preço, independentemente da ocorrência de sinistro que comporte indenização. A álea também não existe para o segurador, porquanto as técnicas atuariais e pesquisas estatísticas permitem prever com precisão a probabilidade dos sinistros em cada grupo de interesses submetidos a riscos homogêneos.

Não há dúvida de que a principal obrigação do segurador é a garantia, prestada desde a conclusão do contrato, e que a indenização é obrigação eventual, quando se materializa o risco. Mas essa constatação não basta para que os adeptos da aleatoriedade do

\footnotetext{
${ }^{607}$ PONTES DE MIRANDA, F. C. Tratado de direito privado: parte especial, cit., t. 45, p. 275. Também sustentam a aleatoriedade PEREIRA, Caio Mário da Silva. Instituições de direito civil. Rio de Janeiro: Forense, 1999. v. 3, p. 453; CARVALHO SANTOS, J. M. Código Civil brasileiro interpretado. Rio de Janeiro: Freitas Bastos, 1988. v. 19, p. 205; ESPÍNOLA, Eduardo. Dos contratos nominados no direito civil brasileiro. Campinas: Bookseller, 2001. p. 658; WALD, Arnoldo. Direito civil: contratos em espécie. São Paulo: Saraiva, 2009. p. 286; ALVIM, Pedro. op. cit., p. 123-124.

${ }^{608}$ COMPARATO, Fábio Konder. O seguro de crédito: estudo jurídico. São Paulo: Ed. Revista dos Tribunais, 1968. p. 136. O autor também discute a natureza do seguro como contrato de garantia, daí se deduzindo a comutatividade dessa relação jurídica, nos Ensaios e pareceres de direito empresarial. Rio de Janeiro: Forense, 1978. p. 537-538; CALMON DE PASSOS, J. J. A atividade securitária e sua fronteira com os interesses transindividuais - responsabilidade da SUSEP e competência da Justiça Federal. Revista dos Tribunais, São Paulo, ano 88, v. 763, p. 95-102, maio 1999; MELLO FRANCO parte dos fundamentos técnicos da operação de seguro, para justificar a comutatividade, apontando que a exploração em massa do seguro pelas empresas seguradoras e as bases técnicas da sua exploração suprimiria a álea, compensando as vantagens de um contrato com as desvantagens de outro Lições de direito securitário: seguros terrestres privados, cit., p. 26; Acrescenta que a obrigação da seguradora de prestar garantia, tal como reconhecida pelo novo Código Civil, enfatiza a comutatividade do contrato. Contratos: direito civil e empresarial, cit., p. 277-278; Ovídio Batista vê no contrato de seguro relação jurídica comunitária, explicando que a seguradora é apenas gestora do monte, poupança coletiva dos segurados, e que cada um deles teria direito a eventual indenização rigorosamente proporcional ao valor atuarialmente determinado para sua contribuição. Argumenta que o papel do segurador se assemelha à figura do trustee no direito inglês, e o valor da indenização a que for condenado judicialmente o segurador será extraído do fundo comum formado pela poupança coletiva. Ao contrário dos negócios jurídicos bilaterais que se formam pela convergência de vontades de contratantes individuais, os contratos de seguro somente se constituem quando ocorre uma multidão de contratos análogos. (...) Para a existência do seguro, é necessária a formação de um grande número de contratos análogos, atuarialmente calculados de modo a formar o fundo de previdência, que transformará o contrato de aleatório em comutativo. Natureza jurídica do Monte Previdência. In: FÓRUM DE DIREITO DO SEGURO JOSÉ SOLLERO FILHO. ESTUDOS DE DIREITO DO SEGURO, São Paulo: IBDS-EMTS, 2002. p. 82; TZIRULNIK, Ernesto. Regulação de sinistro (ensaio jurídico). São Paulo: Max Limonad, 2001. p. 38-39; CAVALCANTI, Flávio de Queiroz B. O conteúdo da prestação securitária e o contrato aleatório. Revista Brasileira de Direito do Seguro e da Responsabilidade Civil, São Paulo, p. 95-112, jan. 2009.
} 
contrato de seguro considerem as obrigações das partes equivalentes, pois examinam cada contrato isoladamente. Se, somente agrupadas, as incertezas podem se transformar em risco mensurável, não seria possível afastar a álea de cada relação bilateral isolada.

Por outro lado, se considerada a operação subjacente, que pressupõe a organização da mutualidade, e reduz a álea à certeza atuarial, o contrato será comutativo. Sendo, em nossa opinião, mais adequado analisar um instituto considerando seu substrato econômico, deve prevalecer a comutatividade do contrato de seguro, que implica correspondência entre prêmio e garantia, sublinhando a importância da informação nesse contexto.

\section{Consensualidade}

O disposto no art. 758 do Código Civil ${ }^{609}$ induz à conclusão de que o contrato é consensual ao se referir à apólice como prova do contrato, pois se é mera prova, não é da substância do ato ${ }^{610}$. Mesmo na vigência do Código anterior, doutrinadores como Pontes de Miranda $^{611}$, Waldemar Ferreira ${ }^{612}$, e Orlando Gomes ${ }^{613}$, entre outros, já sustentavam a consensualidade, pois o art. 1433 considerava perfeito o contrato desde que o segurador remetesse a apólice ao segurado, ou lançasse nos livros a operação $o^{614}$.

Importa frisar que a proposta não vincula o segurador, no curso do prazo de aceitação. Ato unilateral do proponente nem poderia obrigar imediatamente a seguradora, sob pena de não lhe dar oportunidade de verificar a admissibilidade do risco. Como argumenta Vera H. M. Franco, tal interpretação é consentânea com o disposto no art. 427,

\footnotetext{
${ }^{609}$ Art. 758. O contrato de seguro prova-se com a exibição da apólice ou do bilhete do seguro, e, na falta deles, por documento comprobatório do pagamento do respectivo prêmio.

${ }^{610}$ Esta é a conclusão de Ernesto Tzirulnik et al., que consideram, além do teor do dispositivo referido, também a praxe negocial, que de tão comum, teria sido objeto de regulação pela Circular SUSEP 47/80), TZIRULNIK, Ernesto; CAVALCANTI, Flávio de Queiroz. B.; PIMENTEL, Ayrton. O contrato de seguro de acordo com o novo Código Civil brasileiro. 2. ed. São Paulo: Ed. Revista dos Tribunais, 2003.

${ }^{611}$ PONTES DE MIRANDA, F. C. Tratado de direito privado: parte especial, cit., t. 45, p. 298-299.

${ }^{612}$ FERREIRA, Waldemar. Tratado de direito comercial. São Paulo: Saraiva, 1963.v. 2, p. 539-540, § 2.623.

${ }^{613}$ GOMES, Orlando. op. cit., p. 505.

${ }^{614}$ As disposições infralegais também indicam a consensualidade do contrato de seguro. $\mathrm{O}$ art. $2^{\mathrm{o}}$, $\S 1^{\mathrm{o}}$, do Regulamento do DL 73/66, aprovado pelo Decreto 60.459, de 13.3.1967, prevê que a garantia é eficaz a partir da data da aceitação da proposta, e, no $\S 2^{\circ}$, concede o prazo de quinze dias para a emissão da apólice, evidenciando que a eficácia do contrato não depende da emissão deste documento, que pode ser posterior à aceitação. A SUSEP, por meio da Circular 47/80, de acordo com a competência normativa que lhe fora conferida pelo art. $3^{\circ}$ do Regulamento, estabelece prazo para aceitação da proposta, ao fim do qual é considerada tacitamente aceita. TZIRULNIK, Ernesto; CAVALCANTI, Flávio de Queiroz. B.; PIMENTEL, Ayrton. op. cit., p. 43-44.
} 
do Código Civil ${ }^{615}$, e, mais do que isso, só esta interpretação seria condizente com a natureza da operação de seguros ${ }^{616}$.

A lei exige que a emissão da apólice seja precedida de proposta escrita com a declaração dos elementos essenciais do interesse a ser garantido e do risco. ${ }^{617}$ A razão disso é a apontada função da informação como elemento essencial ao contrato de seguro, quando pertinente ao seu objeto, no caso do seguro, o interesse qualificado pelo risco.

\section{Modalidade por adesão}

Contrato de adesão é o negócio jurídico no qual a participação de um dos sujeitos sucede pela aceitação em bloco de uma série de cláusulas formuladas antecipadamente, de modo geral e abstrato, pela outra parte, para constituir o conteúdo normativo e obrigacional de futuras relações concretas ${ }^{618}$.

Caracteriza-se, quanto ao conteúdo, por cláusulas gerais e uniformes formuladas por uma das partes, e, quanto ao modo, pela manifestação do consentimento da contraparte por mera adesão ao bloco de cláusulas contratuais. Portanto, o contrato por adesão não é tipo contratual, mas forma de contratar, pela qual uma das partes predispõe as regras gerais e uniformes que pautarão o contrato, e a outra a elas adere.

$O$ fato de ser necessariamente contratado em massa, como exigência para a viabilização da operação securitária, define o caráter empresarial da atividade securitária e a modalidade de contratar por adesão.

Como contrato de adesão, o seguro se sujeitaria, em tese, ao disposto nos arts. $423^{619}$ e $424^{620}$ Código Civil, que funcionam como fonte suplementar e estabelecem critérios de interpretação e integração aplicáveis a tal modalidade contratual.

Mas suas peculiaridades não permitem a aplicação automática desses dispositivos legais, devido à sua incompatibilidade com a natureza e a função do instituto. Em primeiro

${ }^{615}$ Art. 427. A proposta do contrato obriga o proponente, se o contrário não resultar dos termos dela, da natureza do negócio, ou das circunstâncias do caso.

${ }^{616}$ MELLO FRANCO, Vera Helena de. Contratos: direito civil e empresarial, cit., p. 285.

${ }^{617}$ Art. 759. A emissão da apólice deve ser precedida de proposta escrita com a declaração dos elementos essenciais do interesse a ser garantido e do risco.

${ }^{618}$ GOMES, Orlando. O contrato de adesão: condições gerais dos contratos. São Paulo: Ed. Revista dos Tribunais, 1972.

${ }^{619} \mathrm{O}$ artigo 423 impõe a interpretação mais favorável ao aderente no caso de cláusulas ambíguas ou contraditórias.

${ }^{620} \mathrm{O}$ artigo 424 prevê a nulidade das cláusulas que estipulem renúncia antecipada do aderente a direito resultante da natureza do negócio. 
lugar, a interpretação contra proferentem não é, em geral, aplicável à interpretação do contrato de seguro, pois a estrita regulação ${ }^{621}$ a que está sujeito não permite que as cláusulas sejam elaboradas segundo o arbítrio do segurador, pois as condições gerais são preconizadas pela órgão regulador, ao qual é submetido o clausulado elaborado pelas seguradoras para aprovação prévia. Por sua vez, o agente regulador também tem sua atividade monitorada por setores da sociedade, não lhe sobrando muito espaço para parcialidade, por mais influência que os seguradores pudessem exercer. Por isso, o princípio do in dubio pro segurado nem sempre será aplicável, pois há que se levar em conta o substrato técnico-econômico do seguro, a fim de não desvirtuar sua natureza e função. ${ }^{622}$

A aplicabilidade da norma do art. 424, do Código Civil, que comina de nulidade a estipulação de renúncia antecipada do aderente a direito resultante da natureza do negócio também comporta restrições, para que não seja interpretada como permissão genérica para estender as garantias convencionadas, as quais, pelas razões técnicas já expostas, devem ser interpretadas restritivamente.

A relevância do substrato econômico do instituto não pode ser menosprezada pela lei nem por sua aplicação, sob pena de desfigurar o contrato, com consequências nefastas para toda a coletividade.

A imposição do dever de informar à seguradora se baseia mais na sua expertise do que no fato de se tratar de contrato de adesão, porque, em se tratando de relação jurídica sob estrito controle estatal, a posição de predisponente não lhe confere o mesmo poder de barganha que conferiria em outros contratos por adesão. Por outro lado, a razão da imposição do dever de informar ao segurado se prende ao fato de que a assimetria informacional tende a favorecê-lo, em detrimento não só da seguradora, mas também em relação ao grupo de segurados.

\footnotetext{
${ }^{621} \mathrm{O}$ mercado de seguros tem disciplina legal própria. O Código Civil estabelece as normas gerais do contrato de seguro no Cap. XV (arts. 757 a 802), do Título V, do Livro das Obrigações. O DL 73/66 foi um marco regulatório do setor, e estabelece a política de seguros privados e a organização do sistema e das instituições que o integram (Conselho Nacional de Seguros Privados, Superintendência de Seguros Privados e Institutos de Resseguros do Brasil, mais as sociedades autorizadas a operar seguros privados e corretores habilitados. A L. 6435/77 disciplina a previdência complementar, e a L. 9656/98 dispõe sobre planos e seguro de saúde suplementares, anteriormente regidos pelo DL 73/66. Segue parâmetros e critérios ditados pelo Conselho Nacional de Seguros Privados, ao qual a legislação atribui competência para formular diretrizes. Submete-se à fiscalização da Superintendência de Seguros Privados, órgão de execução da política traçada pelo CNSP, e à qual compete monitorar a constituição, organização e funcionamento das seguradoras e suas operações.

${ }^{622}$ Como pondera Pedro Alvim, a solução mais equitativa seria a interpretação sistemática da cláusula dúbia com as demais disposições contratuais. ALVIM, Pedro. op. cit., p. 175.
} 
Aqui se deu relevo ao que se considerou serem não só as principais características do contrato de seguro, mas as que, associadas às suas já referidas idiossincrasias, impõem ao instituto uma disciplina jurídica especial, e recomendam interpretação consentânea com sua natureza e função.

\section{Aplicabilidade da legislação de consumo}

Embora contratação em massa sugira consumo e o contrato por adesão seja o protótipo de tais relações, esta não é uma inferência necessária e automática, pois nem todo contrato por adesão é de consumo.

O Código de Defesa do Consumidor insere a relação securitária entre as de consumo $^{623}$, conquanto sua aplicação ao contrato de seguro comporte severas restrições. Em primeiro lugar, porque só se pode cogitar de relação de consumo se o segurado, pessoa física ou jurídica ${ }^{624}$, adquire o produto ou utilize o serviço como consumidor final. Mesmo que se admita a suscetibilidade de consumo desse tipo de serviço, ${ }^{625}$ só lhe serão aplicáveis as normas protetivas do consumidor, se e na medida em que sejam compatíveis com o mecanismo e a função da operação de seguro. Por isso, geralmente não será admissível interpretação mais favorável ao consumidor, como, por exemplo, em relação à exclusão contratual de riscos ${ }^{626}$.

No que tange à informação, independente da classificação da relação jurídica como consumo ou não, ambas as partes têm direitos e deveres recíprocos, sempre pautados pela veracidade e pela máxima boa-fé. Ao segurado se deve viabilizar a leitura do contrato com letras legíveis e texto inteligível, de forma que tenha informação adequada do conteúdo do contrato. E deve-se exigir dele o rigoroso cumprimento do dever de prestar declarações claras e verdadeiras a respeito de todo e qualquer fator que possa influenciar a avaliação do

\footnotetext{
${ }^{623}$ Art. $3^{o}$. Fornecedor é toda pessoa física ou jurídica, pública ou privada, nacional ou estrangeira, bem como os entes despersonalizados, que desenvolvem atividades de produção, montagem, criação, construção, transformação, importação, exportação, distribuição ou comercialização de produtos ou prestação de serviços.

$\S 1^{\circ}$. Produto é qualquer bem, móvel ou imóvel, material ou imaterial.

$\S 2^{\circ}$. Serviço é qualquer atividade fornecida ao mercado de consumo, mediante remuneração, inclusive as de natureza bancária, financeira, de crédito e securitária, salvo as decorrentes das relações de caráter trabalhista.

${ }^{624}$ Mais razoável e eficiente seria a solução da Diretiva nº 13, da União Européia, de 5 de abril de 1993, que adotou conceito restritivo de consumidor, como a pessoa física que, nos contratos abrangidos pela diretiva, atue com fins que não pertençam ao âmbito da sua atividade profissional, excluindo da proteção legal a pessoa jurídica, como o fizeram vários países da Europa ocidental.

${ }^{625}$ A abordagem desta matéria escapa ao âmbito deste trabalho.

${ }^{626}$ Esta questão será tratada no próximo capítulo.
} 
risco e a fixação do prêmio pela contraparte, como meio de elidir a assimetria informacional que desfavorece o segurador. ${ }^{627}$

\section{Considerações conclusivas}

As peculiaridades do contrato de seguro em função do mecanismo da operação técnico-econômica subjacente, que implica o tratamento estatístico e atuarial dos riscos agrupados e classificados, com base dados fornecidos pelo proponente, de forma de assegurar a prestação de garantias recíprocas aos segurados, sugere a importância da informação nesse tipo contratual.

${ }^{627} \mathrm{~A}$ discussão das declarações do segurado é matéria do capítulo 8. 


\section{CAPÍTULO 7: OS ELEMENTOS DO CONTRATO DE SEGURO}

A compreensão do papel da informação no contrato de seguro, como atributo de seu objeto, pressupõe a análise da estrutura do instituto e dos elementos que o constituem.

\section{Estrutura do Contrato de Seguro}

Os elementos essenciais do contrato de seguro são: risco, interesse, garantia e prêmio. Sinistro e indenização são elementos acidentais.

\section{Risco segurável}

O risco suscetível de cobertura securitária corresponde à probabilidade de ocorrência de evento futuro e incerto, independente da vontade humana, apto a acarretar perdas patrimoniais. "Risco é definido como variância, medida estatística de dispersão que afere a distância de valores diante de um valor esperado." 628

A incerteza se refere à possibilidade de ocorrência do evento futuro (absoluta) ou ao momento em que ocorrerá (relativa). Em geral, o risco não é necessariamente danoso, mas, no contexto do seguro, não envolve probabilidade de ganho, só de perda (risco puro), como já observado.

Não pode estar relacionado a fatores subjetivos, como dúvidas individuais, porque, para ser passível de cobertura, há que ser objetivamente verificável e mensurável, permitindo o cálculo das probabilidades estatísticas de sua ocorrência e a avaliação da frequência e intensidade de incidência, no agrupamento dos riscos homogêneos.

Daí decorre que o risco deve ser mensurável. Sendo medida indispensável à fixação do valor da prestação do segurado, porque de sua avaliação depende a formação da taxa que será aplicada no cálculo do prêmio, tem que ser objetivo, pois só assim comportará avaliação pelo mecanismo atuarial do seguro.

A precisa mensuração do risco e a consequente precificação do prêmio dependem, como já observado, da veracidade das informações fornecidas pelo proponente na fase pré-

${ }^{628}$ SZTAJN, Rachel. Sistema financeiro, cit., p. 56. 
contratual. Omissões e inverdades ${ }^{629}$ concernentes ao risco distorcerão as obrigações pactuadas e onerarão os recursos comuns em detrimento de todo o grupo.

Como o seguro visa ao tratamento do risco, é indispensável que este preexista à operação, e, como é a medida de precificação do negócio jurídico, é imprescindível que tenha sido predeterminado no contrato. Disso se depreende que, na aplicação da lei, o risco deve ser interpretado restritivamente, pois a interpretação extensiva o desnatura, alterando duas características inerentes à sua natureza: a objetividade e a prefixação. Por isso, na apreciação judicial de cada caso concreto, não se devem acrescentar ao contrato riscos não expressa e claramente previstos. ${ }^{630}$

A doutrina não é assente em relação à qualificação jurídica do risco. Uns o classificam como objeto formal do contrato de seguro, outros, apenas o apontam como elemento essencial ${ }^{631}$, sem definir precisamente sua função no contrato, e há os que o consideram pressuposto ${ }^{632}$.

A considerar, como Darcy Bessone, ${ }^{633}$ que o objeto do contrato é a operação jurídico-econômica pretendida pelas partes, o objeto do contrato seria a obrigação de garantia de um interesse contra um risco predeterminado, mediante pagamento do prêmio. Mas isso implicaria confundir o objeto com a própria operação, e incluir as obrigações de cada uma das partes: no caso do seguro, garantia como prestação do segurador e prêmio, prestação do segurado.

O objeto do contrato não pode ser a própria operação, como argumenta Toledo Piza, mas o que "está diante", tal como se infere da decomposição do termo ob jectum. ${ }^{634}$

\footnotetext{
${ }^{629}$ Omissões e inexatidões de informação nas declarações de risco serão abordadas com o dever de informar no contrato de seguro, no capítulo 8.

${ }^{630}$ Por isso, o dano moral decorrente de ato culposo do segurado contra terceiros, só será segurável, se seu valor for predeterminado na apólice. SZTAJN, Rachel. Seguro de dano moral resultante de acidente com veículo automotor. Revista de Direito Mercantil, Econômico e Financeiro, São Paulo, n. 106, p. 25-34, abr./jun. 1997.

${ }^{631}$ ALVIM, Pedro. op. cit., p. 214; OLIVEIRA, Ivan Marcelo de. Curso de direito do seguro. São Paulo: Saraiva, 2008, TZIRULNIK, Ernesto; CAVALCANTI, Flávio de Queiroz. B.; PIMENTEL, Ayrton. op. cit., p. 38; e ROSSETI, Marco. In: LA TORRE, Antonio (a cura di). Le assicurazioni, cit., p. 104. GASPERONI, Nicola. op. cit., p. 91.

${ }^{632}$ FRONTINI, Paulo Salvador. Seguro - contrato de adesão - cláusulas limitativas de direito, que não se mostram claras e em destaque - nulidade - ocorrência - cláusula de perfil - inoponibilidade - previsão de situações excludentes de indenização que não configuram, ontologicamente, agravamento de risco limitação do prêmio a percentual previamente estabelecido - admissibilidade - inteligência dos arts. 54 do CDC, 51 e 422 a 424 do CC de 2002. Revista de Direito Mercantil, Industrial, Econômico e Financeiro, São Paulo, n. 137, p. 285-294, jan./mar. 2005.

${ }^{633}$ BESSONE, Darci. Teoria geral do contrato. Rio de Janeiro: Forense, 1987, p. 112-113.

${ }^{634}$ PIZA, Paulo Luiz de Toledo. op. cit., p. 180.
} 
Objeto significa aquilo que complementa a operação de seguro, e, portanto, aquilo que se pretende segurar, ou seja, o interesse sujeito a risco. Daí a conclusão de que o interesse segurável é o objeto material do contrato, e o risco segurável, objeto formal, que definiria o "modo de ser do interesse", pois é sobre este que o risco incide. O objeto do contrato de seguro seria, pois, o interesse qualificado pelo risco ${ }^{635}$.

Parece-nos acertada esta concepção do interesse como objeto do contrato, pois é o que se pretende garantir ou segurar, e, como o risco realmente qualifica o interesse, ainda que preexista ao contrato, é assimilado por este como um atributo necessário do objeto, sem o qual é impossível avaliar sua admissibilidade e precificar a garantia pretendida.

Caracterizado o risco como objeto do contrato de seguro ou como seu atributo essencial, a informação que o qualifica também integra o objeto. E a reticência igualmente o compõe, na medida em que for apta a comunicar à contraparte dados relativos ao contrato.

Independente da intenção do proponente, as informações prestadas ou omitidas, relevantes em relação ao objeto do contrato, são aptas a afetá-lo, por ocultarem ou mascararem o verdadeiro risco incidente sobre o interesse segurável.

\section{Seleção de riscos pelo segurador}

O mecanismo da operação securitária não só permite, mas recomenda que o segurador selecione criteriosamente os riscos que admite em suas carteiras. Portanto, não é apenas um direito, mas um dever do segurador, e se justifica, primeiro, porque o segurador é um comerciante sui generis, que não está em oferta permanente, tanto que quem faz a proposta é o segurado, cabendo-lhe aceitar ou não. Sua aceitação deverá depender de fatores técnicos afetos à organização do fundo mútuo.

Ao analisar essa questão da seleção de riscos pelo segurador à luz da legislação de defesa do consumidor, Amadeu Ribeiro ${ }^{636}$, mesmo reconhecendo os efeitos da assimetria de informação, tece algumas considerações que incitam ao debate.

Primeiro, questiona critérios de constituição de grupos segurados, visando a atingir o grau máximo de homogeneidade, e levando ao provável agrupamento de segurados em

\footnotetext{
${ }^{635}$ COMPARATO, Fábio Konder. $O$ seguro de crédito: estudo jurídico, cit., p. 23; MELLO FRANCO, Vera Helena de. Contratos: direito civil e empresarial, cit., p. 294; PIZA, Paulo Luiz de Toledo. op. cit., p. 180.

${ }^{636}$ RIBEIRO, Amadeu Carvalhaes. Direito de seguros. São Paulo: Atlas, 2006. p. 98-100.
} 
função de idade, sexo e etnia. Isso acarretaria, no seguro de vida, a cobrança de prêmios mais altos dos homens, ainda que estes nada possam fazer para eliminar o fato natural de que sua expectativa de vida é menor do que a das mulheres. Abstraídas as eventuais razões da maior longevidade das mulheres, é de se questionar se seria relevante, considerando-se o substrato econômico do contrato de seguro, o fato de os homens nada poderem fazer em relação a tal circunstância. A regulação deveria perquirir antes, até que ponto a seguradora cumpre melhor ${ }^{637}$ sua função sócio-econômica de pulverizar os riscos, usando este ou aquele critério.

No mais, não se pode vislumbrar afronta ao direito do consumidor pelo simples fato de uns, seja pelo sexo, pela idade, ou qualquer outro fator, representarem riscos maiores do que outros. A equiparação dos gêneros para todo e qualquer efeito induziria a tratamento igual aos desiguais, o que nem sempre será justo e eficiente. O critério distintivo entre os sexos para efeito de seguro não deveria ser vedado, por não ser um mal em si mesmo, pois não representa discriminação indevida, mas necessária à mensuração e classificação de riscos inerente ao exercício regular da atividade securitária. A imposição de igualdade de tratamento a todos os segurados comprometeria a função do segurador privado, que não tem as mesmas características do sistema de seguros públicos. No limite, o critério da igualdade absoluta, a par de não ser realmente critério, transformaria os seguros privados em seguridade social.

$\mathrm{O}$ autor também questiona a seleção de riscos bons e exclusão dos ruins pelo segurador, e, apesar de admitir que ao segurador só resta uma solução técnica para evitálos, afirma que, sob a óptica do Direito, esta solução seria ilícita, porque não trata os segurados com igualdade, como se depreende do seguinte trecho: "a estratégia dos segurados detentores de riscos elevados teria um efeito nocivo sobre a carteira do segurador, qual seja, o de torná-la uma carteira repleta de riscos ruins", referindo-se à seleção adversa. E “isso forçaria o segurador a cobrar prêmios mais elevados, o que naturalmente afastaria cada vez mais os riscos bons de sua carteira, pois estes seriam atraídos por carteiras de seguradores que fizessem a seleção entre riscos bons e riscos ruins." E o autor conclui: "Só pode ser uma, portanto, a solução técnica dada pelo segurador: segregar riscos bons e riscos ruins, aceitando apenas os primeiros. Ainda que perfeitamente legítima do ponto de vista técnico, a solução é questionável do ponto de

${ }^{637}$ Tanto da perspectiva de justiça como de eficiência. 
vista jurídico. Afinal, é lícito que o segurador se recuse a prestar serviços a grupos detentores de riscos mais elevados?" (grifos nossos)

Em se reconhecendo que a técnica obriga o segurador a discriminar riscos, parecenos um contrassenso o Direito não aceitá-la, sob o argumento de que não seria lícita. E por que seria ilícita? Onde estaria a ilicitude em tratar desigualmente riscos desiguais? Porque é disso que se trata aqui. Não é de igualdade, é de isonomia. E tratamento isonômico é perfeitamente lícito. À luz do mecanismo da operação de seguros, seria ilógico e atécnico impor tratamento igual a riscos diferentes. Como também seria paradoxal o órgão regulador exigir do segurador a aceitação de todo e qualquer risco. Se a contratação do seguro se inicia com uma proposta do segurado, não por acaso assim denominada, ao Direito não repugna a eventual recusa da seguradora em aceitar o risco a ela proposto (e não imposto). E esta constatação decorre da letra e do espírito da lei, além de ser evidentemente compatível com o mecanismo de seleção de riscos, que assegura a integridade do fundo mútuo e, no limite, a solvência da empresa seguradora. Entendendo esse mecanismo da operação de seguros, como Amadeu Ribeiro explica com magistral clareza na sua obra, e que é da essência do instituto, como, então, concluir pela ilicitude da seleção de riscos, que o próprio autor reconhece como única solução técnica? Se a técnica é inerente e, portanto, indispensável a determinado instituto jurídico, não se pode impedila sem desnaturar o contrato, porque esta técnica corresponde ao seu substrato econômico. A regulação deve evidentemente monitorar a atividade securitária, levando em conta o interesse dos consumidores, se e quando aplicáveis as normas que regem as relações de consumo, mas sem perder de vista a natureza, a função e o mecanismo do instituto. $\mathrm{O}$ estudo dos efeitos da seleção adversa demonstra que, se estes não forem evitados, as seguradoras atrairão cada vez mais riscos ruins, numa espiral crescente e perigosa, conhecida como espiral da morte. Certamente não seria este o objetivo da regulação.

Ainda nesse contexto da seleção de riscos, o Tribunal de Justiça da União Europeia recentemente declarou inválido, a partir de 21.12.2012, o artigo 5.2 da Diretiva 2004/113 UE, que admitia o critério de gênero como fator atuarial em matéria de seguro, desde que cumpridos determinados requisitos. Trata-se de questão prejudicial, e, uma vez suspenso o processo para sua apreciação, foi remetida ao referido tribunal para que se pronunciasse sobre a validade do dispositivo que permitia aos Estados-membros derrogar a regra da igualdade absoluta em matéria de seguros, desde que a distinção tivesse base atuarial comprovada e que tivesse sido instituída até 21/12/2007. Cumpridos estes requisitos os 
Estados-membros estariam implicitamente autorizados a manter a vigência do critério de gênero como fator atuarial por tempo indeterminado. O cerne da questão prejudicial era este.

O Conselho de Ministros da Bélgica, contra o qual foi deduzida essa questão prejudicial, argumentou que as situações dos segurados dos sexos feminino e masculino, em relação a certos ramos dos seguros privados, não se podem considerar equivalentes, porque, do ponto de vista da técnica securitária, que classifica os riscos com base em estatísticas por categorias, os níveis de risco segurado são diferentes entre mulheres e homens. Sustentou que a opção prevista no artigo 5º , n. 2, da Diretiva 2004/113 só visa permitir que situações diferentes não sejam tratadas de modo igual. Invoca a jurisprudência do próprio Tribunal de Justiça, segundo a qual o princípio da igualdade exige que situações análogas não sejam tratadas de modo diferente e que situações diferentes não sejam tratadas de modo igual, exceto se esse tratamento for objetivamente justificado.

Rejeitados os fundamentos do Conselho, foi decretada a invalidade do dispositivo 5.2 da Diretiva 113. A decisão do Tribunal de Justiça da União Europeia foi muito criticada, tanto na área técnica ${ }^{638}$ como na acadêmica. As reações gravitam em torno da base técnica da operação de seguros e do binômio igualdade-isonomia. Argumentam que tratamento igual a desiguais não é igualdade, e que equiparar os sexos para efeito de seguro será discriminatório, porque imporá ônus mais pesados sobre os riscos mais leves, cruzando os subsídios de prêmios entre o gênero feminino e o masculino. Nos seguros de danos e responsabilidade civil, como, por exemplo, no seguro de veículos, a inaplicabilidade do critério de gênero incentivará comportamentos mais arriscados, já que a categoria de motoristas estatisticamente mais cuidadosos (sexo feminino) subsidiará os mais negligentes e imprudentes (sexo masculino). Outro argumento recorrente é a seleção adversa, porque o seguro tenderá a ficar mais caro, e afugentará os riscos bons. Além disso, há os custos de transação relativos à implementação da alteração ${ }^{639}$.

Criticando a decisão do tribunal europeu, que acendeu a controvérsia ao vedar a adoção do critério de gênero como fator de determinação do prêmio nos contratos de seguro, Veiga Copo e Graells afirmam que a interpretação 'maximalista' do direito à

\footnotetext{
${ }^{638}$ EU Gender Directive Eight MONTHS On, Association of Financial Mutuals Annual. Conference and AGM - $3-4 \quad$ Nov. 2011.2 Disponível em: $<$ http://www.financialmutuals.org/files/files/EU\%20Gender\%20Directive.pdf $>$.

${ }^{639}$ HM TREASURY UK response to the 1 March European Court of Justice ruling that insurance benefits and premiums after 21 December 2012 should be gender-neutral: a consultation. Dec. 2011. Disponível em: <http://www.hm-treasury.gov.uk/d/condoc_insurance_benefits_and_premiums.pdf >.

BRADLEY, Ger, CORRY, Dermot, BURNS, Keith. Impact of ECJ Judgement. Disponível em: <https://web.actuaries.ie/sites/default/files/event/2011/03/110315\%20Gender\%20Directive.pdf>.
} 
igualdade de tratamento entre homem e mulher representa um retrocesso em matéria de regulação de seguros, por desconsiderar o mecanismo da operação securitária. Invocando a orientação unânime dos expoentes da literatura europeia de seguros, os autores afirmam que a mensuração do risco é premissa iniludível ${ }^{640}$. De fato, é da essência do seguro discriminar e classificar riscos para tarifar prêmios, com base no princípio da proporcionalidade entre estes dois fatores. Desconsiderar essa propriedade inerente ao contrato de seguro implica desnaturar o instituto. Além disso, provoca externalidades negativas, pois os riscos bons subsidiarão os ruins, arcando com custos que não lhe deveriam ser impostos. ${ }^{641}$ A vedação da distinção entre sexos para fins de mensuração do risco nos contratos de seguro reflete a percepção distorcida da função social do contrato, que o desnatura, desvirtuando sua verdadeira finalidade, para, no limite, extingui-lo, transformando-o em seguro social, que é orientado por princípios diferentes, por ter natureza e função diversas. Seria função do Direito criar obstáculos técnicos à atividade securitária privada, como se dificultá-la ou desnaturá-la tivesse alguma utilidade social? ${ }^{642}$

Completamente equivocada a interpretação de igualdade do tribunal europeu, que desconsiderou a natureza e o mecanismo do contrato de seguros, como se a ignorasse ${ }^{643}$, e repercutiu muito mal não só no mercado securitário, mas nos meios acadêmicos.

\footnotetext{
${ }^{640}$ VEIGA COPO, Abel B.; SÁNCHEZ GRAELLS, Albert. Discriminación por razón de sexo y prima del contrato de seguro. Disponível em: <http://ssrn.com/abstract=1844492>.

${ }^{641}$ Rachel Sztajn analisa externalidades negativas geradas por decisões judiciais incompatíveis com a natureza e a função dos institutos a que se referem e divorciadas do contexto sócio-econômico, em SZTAJN, Rachel. Externalidades e custos de transação: a redistribuição de direitos no novo Código Civil. Revista de Direito Mercantil, Industrial, Econômico e Financeiro, São Paulo, n. 133, p. 7-31, jan./mar. 2004.

${ }^{642}$ Discutindo a função social prescrita como limite à liberdade de contratar no art. 421, do Código Civil, Sztajn argumenta que contrato é "instituição social que se destina a resolver problemas de coordenação na circulação de bens e na distribuição de riscos entre contratantes" (p. 313). Esta é a sua inerente função social. Acrescenta que "a função social do contrato tem de conviver com a dinâmica dos mercados; objetivo das normas de direito positivo, e também das sociais, seria diminuir os riscos e estimular o cumprimento das promessas como forma de facilitar a continuidade da atividade econômica." (p. 315) SZTAJN, Rachel. Função social do contrato e direito de empresa. In: TIMM, Luciano Benetti; MACHADO, Rafael Bicca (Coord.). Função social do direito. São Paulo: Quartier Latin, 2009.

Timm e Machado, analisando a função social do Direito, concluem que "a opção por um modelo que respeite o mercado (e os institutos a si tão caros, como a propriedade, os contratos, etc) é a mais eficiente socialmente, e a que melhor atende a função social do Direito." "TIMM, Luciano Benetti; MACHADO, Rafael Bicca. Direito, mercado e função social. __________. (Coords.). Função social do direito, cit., p. 272-273.

${ }^{643}$ Isso remete à famosa advertência de Vivante: "Non si avventurino mai ad alcuna trattazione giuridica se non conoscono a fondo la struttura tecnica e la funzione economica dell'instituto che é oggetto dei loro studi. Raccolgano nelle Borse, nelle banche, nelle agenzie, nelle società commerciale, nelle cancellerie giudiziarie, il materiale necessario per intendere quella strututtura e quelle funzione. È una slealtà scientifica, è un difetto di probitá parlare di un istituto per fissarle la disciplina giuridica senza conoscerlo a fondo nella sua realtà. Se il diritto ha per iscopo di regolare gli effeti di un istituto, è evidente che lo studio pratico della sua natura deve precedere quello del diritto." VIVANTE, Cesare Vivante. Tratatto de diritto commerciale. Torino: Fratelli Bocca, 1905. v. 1, p. VIII.
} 


\section{Exclusão legal de riscos}

Ao tratar da classificação dos riscos na abordagem do mecanismo da operação de seguro, já foi mencionado que os riscos seguráveis devem ser puros, estáticos, e individualizados, o que exclui riscos especulativos, dinâmicos e aqueles que podem afetar número indeterminado de pessoas.

Além disso, as exclusões legais são definidas pela natureza do interesse sobre o qual recai o risco. Assim, estariam excluídos por lei os riscos incidentes sobre interesses ilícitos ou ilegítimos.

Também não são seguráveis riscos provocados intencionalmente pelo próprio segurado. Neste contexto, surge a discussão da segurabilidade do suicídio no seguro de vida $^{644}$.

${ }^{644} \mathrm{O}$ Código Civil anterior só admitia o seguro de vida para morte involuntária (art. 1440, § único), e considerava o suicídio como morte voluntária, se premeditado por pessoa mentalmente saudável. O fundamento para a exclusão do suicídio era que, se o sinistro pudesse ser provocado pelo próprio segurado, não se trataria de risco, o que desnaturaria o seguro, como ponderava Bevilaqua. BEVILÁQUA, Clóvis. Código Civil comentado. Rio de Janeiro: Francisco Alves, 1953. v. 5, p. 201.

A lógica seria considerar todo suicídio como ato voluntário, já que, em tese, e ainda que movido por desespero, ninguém se mataria se não o quisesse. Mas a legislação anterior, considerando morte involuntária o suicídio premeditado, autorizava a exegese que lhe davam os tribunais, garantindo a indenização ao beneficiário sempre que não se provasse a premeditação do suicídio.

Considerações de ordem psicológica desafiavam a distinção entre voluntariedade e involuntariedade em matéria de suicídio. Pedro Alvim, louvando-se em Nelson Tafuri, afirma que o comprometimento da vontade do suicida encontra fundamentos na psiquiatria, que considera o suicídio anomalia psíquica, temporária ou permanente, e também na psicanálise, segundo a qual o suicídio seria o homicídio invertido, resultante do masoquismo do ego ou do sadismo do superego; e na sociologia, para a qual o suicídio é provocado por fatores sociais ou econômicos, agravados pela inadaptação do suicida à vida social. ALVIM, Pedro. op. cit., p. 236-237.

Refletindo essa ordem de considerações, a jurisprudência passou presumir a involuntariedade do suicídio, até prova em contrário, o que implica a inversão do ônus probatório para impor ao segurador a demonstração da premeditação, já que não bastava a voluntariedade, apesar de nem todo ato voluntário ser premeditado. A dificuldade de produção dessa prova acabou permitindo a cobertura irrestrita dos suicídios, mesmo ocorridos poucos meses ou até dias depois da celebração do contrato de seguro.

Tudo indica que isso levou o novo Código Civil, no art. 798, a tentar harmonizar o aspecto social da questão com os aspectos técnicos da operação de seguro, fixando um prazo de carência de dois anos para admitir o suicídio como risco, de forma a excluir todos os suicídios - voluntários ou não - praticados antes desse prazo. É exatamente isto que diz a clareza solar da lei. A regra do art. 798 estabelece presunção absoluta de que o suicídio praticado no prazo ali fixado seria voluntário, não comportando prova em contrário. Com isso, a lei, por um lado, admite os fundamentos psiquiátricos, psicológicos e sociológicos da possível involuntariedade do suicídio, mas, de outro, reconhece a incompatibilidade do mecanismo do seguro com a assunção de riscos provocados pelo próprio segurado, excluídos os casos de culpa, que não se confundem com o suicídio, porque, se decorrente de negligência ou imprudência, será morte acidental. Com a fixação do prazo de carência, a lei achou, pois, uma forma de compor os interesses de ambas as partes. Essa carência é reconhecida em vários códigos europeus, como, por exemplo, o art. L132-7, do Código de Seguros da França, e o art. 1927, do Código Civil italiano, modelo legislativo sobre o qual foi calcado o nosso atual código civil.

Portanto, na vigência do novo Código, não haveria margem para apreciação da voluntariedade do ato, porque a lei objetivamente considera qualquer suicídio como risco coberto, após o prazo de dois anos contado da celebração do contrato, e, descoberto, se ocorrido antes desse prazo (art. $798 \mathrm{CC}$ ). Se alguma 


\section{O risco como medida de cálculo do prêmio}

É a variação do risco que define o prêmio. Quanto maior a probabilidade de se concretizar o risco, maior o prêmio. Por isso, este não é igual para todos, pois o risco de cada integrante do grupo segurado varia conforme a probabilidade de sua incidência.

Já abordado o aspecto técnico da operação de seguro, aqui nos limitamos a reiterar que, se o risco funciona como fator de cálculo do prêmio, erros nesse cálculo alteram toda a base econômica da operação e afetam o equilíbrio do contrato, prejudicando o fundo mútuo. Por isso, omissões ou distorções nas informações prestadas pelo segurado em relação ao risco a que está submetido seu interesse, distorceriam o cálculo.

As declarações do segurado, suas eventuais omissões e inexatidões serão abordadas no próximo capítulo, que tratará do dever de informar no contrato de seguro.

\section{Exclusão contratual de riscos}

$\mathrm{Na}$ abordagem da modalidade do contrato de seguro como contrato por adesão salientou-se que a predisposição das cláusulas gerais pelo segurador não é apenas fator de redução de custos de transação, e de celeridade da contratação. Resulta do caráter multitudinário da operação de seguros e da estrita regulação do setor securitário, que exige o protocolo do clausulado, perante o órgão regulador, para prévia aprovação. Por isso, a

dúvida pudesse suscitar o dispositivo legal seria quanto ao termo a quo da vigência do contrato. Mas, a despeito da clareza da norma, a jurisprudência continuou a conceder cobertura securitária ao suicídio cometido no prazo de carência, persistindo na interpretação da voluntariedade relacionada à contratação do seguro, que se resume em premeditação, como se não fosse de direito a presunção estabelecida pela lei. Indiferentes à presunção legal, decisões judiciais continuam invocando a Súmula no 105 STF: "Salvo se tiver havido premeditação, o suicídio do segurado no período contratual de carência não exime o segurador do pagamento do seguro." Apenas a título de ilustração, excerto jurisprudencial que reflete a interpretação equivocada dos tribunais superiores: TJ/RS - "Apelação Cível No 70042886184, Rel. Ney Wiedemann Neto, 6 ${ }^{a}$ Câmara Cível, DJ 27/10/2011: Apelação cível. Seguros. Ação de cobrança. Seguro de vida. Suicídio. Aplicação do Código de Defesa do Consumidor aos contratos de seguro. Ocorrência dentro do prazo de dois anos disposto no art. 798, caput, do Código Civil. Necessidade de comprovação de premeditação pra fim de afastamento do dever de indenizar. Na hipótese de o suicídio ocorrer no prazo de carência, apenas não será devida a indenização se comprovado que o auto-extermínio foi premeditado. Agravamento do risco não comprovado. Suicídio involuntário. Acidentalidade presumida. Voluntariedade não demonstrada pela seguradora. Inteligência das Súmulas 61 do STJ e 105 do STF. É inoperante a cláusula que exclui a responsabilidade da seguradora em casos de suicídio. Apelo desprovido."

A presunção legal não permitiria que, decorrido o lapso temporal de dois anos, se questione nem a voluntariedade nem a premeditação do suicídio. Se presunção estabelecida pelo art. 798 permitisse a perquirição da voluntariedade do suicídio ocorrido durante o prazo de carência, pela mesma lógica, deveria também permitir que se cogitasse da voluntariedade em relação ao suicídio ocorrido após esse prazo, e legalmente incluído na cobertura, com base na presunção de involuntariedade.

A assimetria informacional se manifestará no processo judicial, pois a prova de premeditação do suicídio, que incumbe ao segurador, dependerá, via de regra, de informações privativas dos beneficiários do morto, e estes evidentemente não terão incentivo algum para prestá-las. 
padronização dos instrumentos contratuais é ditada principalmente pelo interesse social e econômico envolvidos.

Se o risco serve como medida de precificação da garantia, ele deve ser perfeitamente determinado no contrato e comporta limitação, de acordo com as bases técnicas da operação.

Admite-se, como pondera Vera H. M. Franco, a exclusão de risco que, por suas características particulares, possam comprometer o equilíbrio da mutualidade, desde que a exclusão seja claramente expressa no contrato $^{645}$. A exclusão deve ser formal, objetiva, específica e inequívoca, de modo a não suscitar dúvidas sobre seu alcance ${ }^{646}$.

Surge novamente, neste contexto, o problema da interpretação extensiva dos riscos contratados, contrariando a regra elementar do seguro, que é a predeterminação do risco (art. 757, Código Civil $^{647}$ ), sem a qual se inviabilizam os cálculos atuariais. Halperín recomenda que a extensão do risco e a garantia outorgada devem interpretar-se literalmente, advertindo que qualquer concessão ou interpretação que importe ampliação da garantia convencionada, produzirá grave desequilíbrio no conjunto de operações da companhia. ${ }^{648}$

A despeito da modalidade por adesão, os contratos de seguro não podem ser interpretados, como já ressaltado, à luz dos artigos 423 e 424, do Código Civil, quando tais normas forem incompatíveis com a operação econômica subjacente. Essa incompatibilidade se evidencia na apreciação de controvérsia a respeito de riscos contratualmente excluídos à luz das normas de interpretação e integração do contrato por adesão, especialmente o art. 423, que prescreve interpretação favorável ao aderente, e cuja aplicação implicará afronta ao disposto art. 757, do Código Civil, que restringe a garantia contratada aos riscos pré-determinados, desnaturando o contrato.

A par disso, o favorecimento indevido de um segurado afetará todos os demais integrantes do grupo, cujos recursos comuns serão colocados à disposição de um risco não assumido no contrato. Ainda que este efeito não seja claramente visível, é possível inferi-lo a partir do próprio mecanismo da operação de seguro, que permite verificar que a extensão

\footnotetext{
${ }^{645}$ MELLO FRANCO, Vera Helena de. Contratos: direito civil e empresarial, cit., p. 296-297.

${ }^{646}$ Lambert-Faivre adverte que a redação da cláusula seja direta e explícita, não dependendo de interpretação a contrario sensu. LAMBERT-FAIVRE, Yvonne. op. cit., p. 36.

${ }^{647}$ Art. 757 CC. Pelo contrato de seguro, o segurador se obriga, mediante o pagamento do prêmio, a garantir interesse legítimo do segurado, relativo a pessoa ou coisa, contra riscos pré-determinados.

${ }^{648}$ HALPERIN, Isaac. op. cit., p. 212.
} 
indevida do risco assumido pelo segurador, em benefício de um dos segurados, altera os índices aplicados ao risco, onerando o fundo comum. E quantos mais forem contemplados com esse benefício extensivo, mais externalidades negativas serão impostas à mutualidade, além dos efeitos de segunda ordem no âmbito da responsabilidade civil, referidos no capítulo anterior.

Pelas mesmas razões, não se aplicam as normas protetivas do consumidor, para interpretar extensivamente o risco em favor do segurado em juízo ${ }^{649}$. Esses benefícios indevidos extrapolam o âmbito da relação bilateral, alcançando não só o fundo comum, mas toda a coletividade, porque tendem a gerar aumento de preço, provocando seleção adversa. Não é objetivo da legislação de defesa do consumidor a proteção de alguns em detrimento de toda a coletividade. ${ }^{650}$

Atenta à nocividade dos efeitos da extensão indevida de riscos cobertos, a Diretiva 13/93 da União Europeia exclui a priori a abusividade das cláusulas de contratos de seguros, que definam ou delimitem claramente o risco segurado e o compromisso do segurador, desde que essas limitações sejam consideradas no cálculo do prêmio a pagar pelo consumidor. A exceção expressa se justifica, porque leva em conta as peculiaridades do contrato de seguro, respeitando o mutualismo que lhe é inerente e observando os cálculos atuariais que asseguram seu equilíbrio econômico.

Em suma, a extensão do seguro a riscos não previamente estipulados rompe a relação de equilíbrio entre as prestações recíprocas, e onera o fundo comum aos demais segurados do grupo, em detrimento dos direitos destes.

\footnotetext{
${ }^{649}$ TIMM e FERREIRA ALVES discutem a aplicação indevida da legislação protetiva do consumidor, abordando os efeitos de segunda ordem de tais decisões em ALVES, Francisco Kummel Ferreira; TIMM, Luciano Benetti. Custos de transação no contrato de seguro: proteger o segurado é socialmente desejável? In: TIMM, Luciano Benetti (Org.). O novo direito civil: ensaios sobre o mercado, a reprivatização do direito civil e a privatização do direito público. Porto Alegre: Livr. do Advogado, 2008. p. 124-125.

${ }^{650}$ Comentando os efeitos de normas destinadas à tutela das partes consideradas mais vulneráveis numa relação jurídica, Sztajn afirma que podem acarretar aumento de custos de transação, redução da eficiência alocativa, e, a despeito de seu intuito de corrigir falhas de mercado, podem provocar distorções e criar externalidades negativas. SZTAJN, Rachel. Notas de análise econômica: contratos e responsabilidade civil. Revista de Direito Mercantil, Industrial, Econômico e Financeiro, São Paulo, n. 111, p. 13-14, jul./set. 1998.
} 


\section{Agravamento do risco}

A dificuldade de monitoramento das ações do segurado durante a vigência do contrato incentivam comportamentos oportunistas (moral hazard), aumentando a possibilidade de incidência dos riscos previstos no contrato.

O agravamento afeta a relação risco-prêmio, em prejuízo do fundo comum, que arcará com obrigações mais elevadas em comparação com a respectiva contraprestação representada pelo prêmio.

\section{Agravamento intencional}

A manutenção da proporcionalidade risco-prêmio e a proteção da mutualidade são fundamentos das normas destinadas a coibir condutas dolosas ou culposas que aumentem a probabilidade do risco ou a severidade do eventual sinistro.

O art. 768, do Código Civil ${ }^{651}$ prevê perda da garantia para o caso de agravamento do risco. Mas, ao exigir que seja intencional, a lei neutraliza completamente a própria eficiência, em face da dificuldade procedimental da prova do elemento subjetivo. ${ }^{652}$

$\mathrm{O}$ advérbio intencionalmente tem sido interpretado como intenção de agravar o risco, sugerindo que não bastaria a prática intencional de ato que levasse à agravação ${ }^{653}$. Essa interpretação doutrinária e jurisprudencial, embora autorizada pela literalidade do dispositivo, trai sua finalidade ${ }^{654}$.

\footnotetext{
${ }^{651}$ Art. 768. O segurado perderá o direito à garantia se agravar intencionalmente o risco objeto do contrato. ${ }^{652}$ MELLO FRANCO, Vera Helena de. Contratos: direito civil e empresarial, cit., p. 297.

${ }^{653}$ TZIRULNIK, Ernesto; CAVALCANTI, Flávio de Queiroz. B.; PIMENTEL, Ayrton. op. cit., p. 81.

${ }^{654} \mathrm{~A}$ despeito da evidente intencionalidade do uso da droga, e do óbvio agravamento do risco em decorrência do vício, a decisão ora colacionada desconsidera a agravação, com base numa equivocada intelecção do art. 768, CC, que fala de intenção e não necessariamente de má-fé, porque o ato para ser intencional não precisa ser malicioso. TJ/RS: “Apelação Cível № 70041355967, Rel. Luís Augusto Coelho Braga, $6^{\text {a }}$ Câmara Cível, DJ 11/08/2011: Apelação Cível. Seguro. Agravamento do risco. Necessidade de demonstração da conduta intencional de agravar o risco. $O$ segurado que é dependente de cocaína, ao consumi-la não o faz com má-fé ou visando o agravamento do risco do contrato. Haja vista não considerar a dependência como 'risco de vida'. Por maioria, deram provimento ao apelo".

- O segurado deixa o veículo aberto com as chaves no contato, numa evidente demonstração de moral hazard, que abrange também a culpa, e, no entanto, a decisão judicial não isenta a seguradora da responsabilidade pela indenização pelo furto, apesar de se tratar, no mínimo, de culpa grave. A decisão, calcada só na literalidade da lei, que fala em agravamento intencional, não se dá conta de que é da essência do instituto o princípio do interesse segurável, ou seja, o vínculo entre o segurado e o bem protegido pelo seguro, que exige zelo de um pelo outro. TJ/RS: “Apelação Cível No 70044966224, Rel. Isabel Dias Almeida, 5a Câmara Cível, DJ 19/10/2011: Apelação Cível. Seguro. Furto de veículo deixado com as portas abertas e chave na ignição. Agravamento do risco inocorrente. Ausência de demonstração da má-fé do segurado. Dever de indenizar. 1. Para que a seguradora, ora apelada, restasse isenta do pagamento do seguro, a má-fé ou dolo da parte segurada deveria ter sido cabalmente demonstrada, o que não se
} 
Se, em vez da mera voluntariedade do ato, exigir-se o específico intuito de exacerbar o risco, excluem-se condutas voluntárias que implicam agravamento. A embriaguez na direção de veículo, por exemplo, se subsumiria no tipo do art. 768, porque, via de regra, o ato de beber é voluntário, e é um evidente fator de agravamento intencional de risco. Mas a interpretação de que é necessário o intuito de lesar a seguradora, afasta a incidência da lei, porque ninguém, nem o mais irresponsável dos motoristas, dirigiria embriagado com o objetivo de agravar o risco, e muito menos com a intenção de lesar a seguradora. E, no entanto, agrava-o e o faz voluntariamente.

Se a ratio da lei era, como deveria ser, evitar o comportamento oportunista e o consequente desequilíbrio do contrato em razão da quebra da proporcionalidade riscoprêmio, a escolha das palavras traiu este desiderato.

Se não pretendia fazer valer a sanção cominada, melhor seria que tivesse se limitado a prever objetivamente os efeitos do agravamento do risco, independente da causa, como fez a lei italiana. ${ }^{655}$

verificou na hipótese vertente. Imprescindível a intenção do segurado, não bastando mera negligência ou imprudência deste. Destarte, não comprovado o agravamento intencional do risco contratado, ônus que incumbia à parte ré, nos termos do artigo 333, II, do CPC, é devida a indenização securitária. (...). Deram parcial provimento ao apelo."

- Neste caso, a assertiva de que o descumprimento da cláusula de perfil que previa o estacionamento do veículo em garagem fechada, na residência, trabalho e escola, e a responsabilização da seguradora pelo furto do carro estacionado na rua em frente à escola, sob o argumento de se tratar de caso fortuito e imprevisível, contém incoerências óbvias: a cláusula de perfil vincula o segurado, sim, porque delimita o risco; e o fato de o sinistro ser fortuito e imprevisível, embora óbvio, porque é inerente ao risco individualmente considerado, é evidentemente agravado pelo estacionamento do carro na rua. A seguradora se baseou na cláusula de perfil do segurado para classificar seu risco, cobrando prêmio proporcional a este. Se o perfil incluísse estacionar o carro na rua durante as aulas, o preço do seguro seria mais alto, de onde se conclui, que, independentemente da ocorrência do furto, o segurado agravou o risco. Quanto à má-fé, não é requisito do agravamento, que pode ocorrer inclusive sem culpa do segurado, e, ainda assim, dar ensejo à resolução do contrato. TJ/SP: “Apel. nº 0139887-29.2005.8.26.0000, 30ª Câmara de Direito Privado, 17/08/2011). Veículo automotor - Seguro facultativo - Ação de indenização - Demanda de consumidor Sentença de procedência - Furto do veículo quando estacionado na via pública, período noturno, em local próximo à instituição de ensino onde matriculado o proprietário - Negativa de pagamento administrativo estribada em cláusula de perfil que exige utilização de estacionamento fechado na escola - Inconsistência. Não comprovação do agravamento do risco - Caso fortuito (furto) Imprevisibilidade - Ausência de má-fé - Não violação dos arts. 765 e 766 do CC/2002 - Ré que não se desincumbiu de comprovar fato extintivo, modificativo ou impeditivo do direito do autor (art. 333, II, do CPC) - Indenização devida. Apelo da ré desprovido"

${ }^{655}$ Art. 1898. Aggravamento del rischio.

Il contraente ha l'obbligo di dare immediato avviso all'assicuratore dei mutamenti che aggravano il rischio in modo tale che, se il nuovo stato di cose fosse esistito e fosse stato conosciuto dall'assicuratore al momento della conclusione del contratto, l'assicuratore non avrebbe consentito l'assicurazione o l'avrebbe consentita per un premio più elevato (1926).

L'assicuratore può recedere dal contratto, dandone comunicazione per iscritto all'assicurato entro un mese (2964) dal giorno in cui ha ricevuto l'avviso o ha avuto in altro modo conoscenza (1335) dell'aggravamento del rischio. 
Se a doutrina desse a essa regra do art. 768 sentido compatível com a finalidade a que serve, reduziria sua ineficiência por mostrar que intencional deve ser o ato do qual resulta o agravamento, o que bastaria para a aplicação da sanção ali prevista. A interpretação teleológica seria mais recomendável, porque sintonizada com o objetivo da lei.

\section{Agravamento sem culpa do segurado}

O art. $769, \S 1^{\circ}$, do Código Civil prevê a hipótese de agravamento do risco, sem culpa do segurado, autorizando o segurador a resolver o contrato, mediante comunicação escrita à contraparte, no prazo ali estabelecido ${ }^{656}$. A literalidade da lei indica que a agravação do risco surte efeito tanto antes como depois da ocorrência do sinistro.

Mas não se trata de interpretação apenas literal da lei. A sistemática do regime jurídico do seguro confirma essa exegese, pois o art. 757 define o seguro como o contrato pelo qual "o segurador se obriga, mediante pagamento do prêmio, a garantir interesse legítimo do segurado, relativo a pessoa ou a coisa, contra riscos predeterminados". Tratase, pois, de contrato de garantia, em que o risco coberto é predeterminado na apólice, com base nas informações do segurado. Sendo o risco necessariamente predeterminado, sua alteração, por quaisquer circunstâncias, acarretará necessariamente sua reavaliação. Como o seguro é orientado pelo princípio da proporcionalidade, risco e prêmio devem ser equivalentes, mantendo a proporção inicial durante a vigência do contrato. Esta lógica do seguro emana do mecanismo da operação subjacente examinada no capítulo anterior.

Portanto, não é necessária a ocorrência do sinistro para se caracterizar o agravamento do risco. Primeiro, porque a proporcionalidade diz respeito à relação riscoprêmio, cujo equilíbrio é fundamental no seguro. Segundo, porque sendo o contrato de garantia, o sinistro é elemento acidental, podendo ou não ocorrer. Diante disso, é absurda a

Il recesso dell'assicuratore ha effetto immediato se l'aggravamento è tale che l'assicuratore non avrebbe consentito l'assicurazione; ha effetto dopo quindici giorni, se l'aggravamento del rischio è tale che per l'assicurazione sarebbe stato richiesto un premio maggiore.

Spettano all'assicuratore $i$ premi relativi al periodo di assicurazione in corso al momento in cui ̀̀ comunicata la dichiarazione di recesso.

Se il sinistro si verifica prima che siano trascorsi i termini per la comunicazione e per l'efficacia del recesso, l'assicuratore non risponde qualora l'aggravamento del rischio sia tale che egli non avrebbe consentito l'assicurazione se il nuovo stato di cose fosse esistito al momento del contratto; altrimenti la somma dovuta e ridotta, tenuto conto del rapporto tra il premio stabilito nel contratto e quello che sarebbe stato fissato se il maggiore rischio fosse esistito al tempo del contratto stesso (1932; att. 187).

${ }^{656}$ Art. 769, $\$ 1^{\circ}$ CC. O segurador, desde que o faça nos quinze dias seguintes ao recebimento do aviso da agravação do risco sem culpa do segurado, poderá dar-lhe ciência, por escrito, de sua decisão de resolver o contrato. 
conclusão de que o agravamento do risco só se caracteriza se agravar o sinistro. Se a lei prevê que o risco pode ser agravado antes ou independentemente da ocorrência do sinistro, não tem sentido a orientação jurisprudencial que exige nexo causal entre o agravamento e o sinistro $^{657658}$.

${ }^{657}$ Jurisprudência que equivocadamente exige nexo de causalidade entre o agravamento e o sinistro (grifos nossos):

- STJ: “Agravo Regimental no Agravo em Recurso Especial 2011/0162216-5, Rel. Min. Nancy Andrighi,

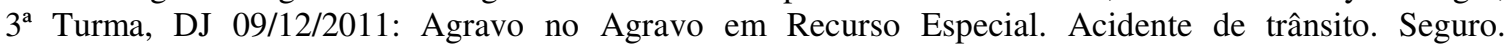
Responsabilidade. Embriaguez do segurado. Agravamento do risco por parte do segurado. Afastamento.

A embriaguez do segurado, por si só, não exime o segurador do pagamento de indenização prevista em contrato de seguro de vida, sendo necessária a prova de que o agravamento de risco dela decorrente influiu decisivamente na ocorrência do sinistro. - Agravo não provido."

- STJ: “AgRg no Ag 1260682 / RJ, Rel. Min. João Otávio de Noronha, 4a Turma, DJE 21/02/2011:

Direito Civil. Cobertura securitária. Motorista embriagado. Agravamento do risco. Não ocorrência.

1. A circunstância de o segurado encontrar-se embriagado, por si só, não é causa de perda de seguro quando a sua conduta não foi condição determinante para a colisão do veículo ou para o agravamento das consequências do sinistro.

2. Agravo regimental desprovido"

- STJ: "REsp 780757 / SP, Rel. Ministro João Otávio de Noronha, 4a Turma, DJE 14/12/2009: Direito Civil. Contrato de seguro. Acidente pessoal. Estado de embriaguez. Falecimento do segurado. Responsabilidade da seguradora. Impossibilidade de elisão. Agravamento do risco não-comprovado. Prova do teor alcóolico e sinistro. Ausência de nexo de causalidade. Cláusula liberatória da obrigação de indenizar. Arts. 1.454 e 1.456 do código civil de 1916.

1. A simples relação entre o estado de embriaguez e a queda fatal, como única forma razoável de explicar o evento, não se mostra, por si só, suficiente para elidir a responsabilidade da seguradora, com a consequente exoneração de pagamento da indenização prevista no contrato.

2. A legitimidade de recusa ao pagamento do seguro requer a comprovação de que houve voluntário e consciente agravamento do risco por parte do segurado, revestindo-se seu ato condição determinante na configuração do sinistro, para efeito de dar ensejo à perda da cobertura securitária, porquanto não basta a presença de ajuste contratual prevendo que a embriaguez exclui a cobertura do seguro.

3. Destinando-se o seguro a cobrir os danos advindos de possíveis acidentes, geralmente oriundos de atos dos próprios segurados, nos seus normais e corriqueiros afazeres do dia-a-dia, a prova do teor alcóolico na concentração de sangue não se mostra suficiente para se situar como nexo de causalidade com o dano sofrido, notadamente por não exercer influência o álcool com idêntico grau de intensidade nos indivíduos.

4. A culpa do segurado, para efeito de caracterizar desrespeito ao contrato, com prevalecimento da cláusula liberatória da obrigação de indenizar prevista na apólise, exige a plena demonstração de intencional conduta do segurado para agravar o risco objeto do contrato, devendo o juiz, na aplicação do art. 1.454 do Código Civil de 1916, observar critérios de eqüidade, atentando-se para as reais circunstâncias que envolvem o caso (art. 1.456 do mesmo diploma).

5. Recurso especial provido"

- TJ/SP: “Apelação com Revisão no 0395522-21.2008.8.26.0577, DJ 26/04/2011: Seguro de vida e acidentes pessoais. Indenização. Alegação da seguradora de que o segurado agravou o risco ao conduzir motocicleta sem a devida habilitação. Ausência de prova de que o motociclista deu causa ao acidente. Falta de habilitação que constitui infração administrativa. Inteligência do artigo 333, inciso ii, do cpc. Sentença mantida. Recurso improvido. É de rigor o improvimento do apelo, pois o acervo probatório não é capaz de afirmar que foi o motociclista que deu causa ao acidente de que foi vítima. Além disso, também não restou demonstrado nos autos que a falta de habilitação do segurado tenha sido a causa determinante do acidente. Ora, é necessário que, além da falta de habilitação, o condutor gere perigo de dano, ou seja, perigo concreto. Como tal não restou demonstrado nestes autos, sendo que competia à ré a comprovação de fato impeditivo ou modificativo do direito do autor, deve arcar com o pagamento da indenização tal como estabelecido em primeira instância".

- TJ/RS: “Apelação Cível No 70045454816, Rel. Katia Elenise Oliveira da Silva, $11^{a}$ Câmara Cível, DJ 23/11/2011: Apelação Cível. Responsabilidade civil em acidente de trânsito. Ação de reparação de danos. Reconvenção. Responsabilidade subjetiva. Ambos os motoristas contribuiram para o acidente devendo cada um arcar com a metade das despesas da parte adversa. Seguro. Exclusão de cobertura. Impossibilidade. 
Necessário comprovar que o agravamento de risco (embriaguez) foi condição determinante para a ocorrência do sinistro. Unânime. Proveram em parte o apelo do autor e o recurso do réu."

- TJ/RS: “Apelação Cível No 70045263936, Rel. Romeu Marques Ribeiro Filho, 5a Câmara Cível, DJ 14/12/2011: Apelação Civel. Seguro de vida. Agravamento de risco. Não comprovado. Aplicação do Codigo de Defesa do Consumidor. Dever da seguradora de adimplir o seguro. Sentença mantida. O Código de Defesa do Consumidor, em seu art. $3^{\circ}, \S 2^{\circ}$, traz a definição de serviço e, nesta definição, se inclui a atividade securitária. Para que a seguradora restasse isenta do dever de indenizar, deveria demonstrar a relação de causalidade entre o estado de embriaguez do motorista e o sinistro. Inexistindo comprovação do agravamento de risco, não há como ser desonerada a seguradora do cumprimento do pactuado no contrato de seguro firmado. Apelo desprovido."

- Este caso é ilustra bem que não seria necessária a ocorrência do sinistro, e, portanto, a relação deste com a conduta do segurado, para se constatar o agravamento do risco. Mas, pelo teor da fundamentação, a isenção de responsabilidade ocorreu, porque o segurado, participando de racha, deu causa ao sinistro. Portanto, a despeito do acerto da decisão, a fundamentação é equivocada. TJ/RS: “Apelação Cível No 70045807476 , Rel. Isabel Dias Almeida, $5^{a}$ Câmara Cível, DJ 23/11/2011: Apelações Cíveis. Ação de cobrança. Seguro. Acidente de trânsito. Participação do condutor em "racha". Agravamento do risco. Indenização indevida. $1 . \mathrm{O}$ artigo 765 do $\mathrm{CC}$, ao regular o pacto de seguro, exige que a conduta dos contratantes, tanto na celebração quanto na execução do contrato, seja pautada pela boa-fé. 2. Hipótese que em a prova produzida demonstra que o condutor estava participando de "racha", fator determinante para a ocorrência do sinistro. Assim, tendo agravado o risco do contrato, resta afastado o dever de indenizar da seguradora, nos termos dos artigos 766 e 768 do CC. Precedentes. (...)Negaram provimento aos apelos.

- Mesmo decisões que reconhecem o agravamento do risco, isentando de responsabilidade a seguradora, o fundamento de que o nexo entre conduta agravante e sinistro seria requisito para a agravação deixa entrever percepção equivocada da operação de seguro e do princípio da proporcionalidade entre risco-prêmio, que lhe é inerente: TJ/SP: “Apel. no 0001303-07.2007.8.260066, 36 Câmara de Direito Privado, DJ 27/10/2011: Seguro de vida a acidentes pessoais - Ação de cobrança de indenização securitária - Sentença de procedência - Apelação da demandada prova suficiente a relacionar a embriaguez com o acidente que causou a morte do segurado, determinando-o, há sim - assim desenhado o agravamento do risco do sinistro, caso era e é de afastar-se o dever da seguradora de indenizar - Recurso provido."

${ }^{658}$ Mesmo reconhecendo o agravamento do risco e isentando a responsabilidade da seguradora, a jurisprudência invoca o fundamento, a nosso ver, equivocado, do nexo causal entre a conduta apontada como agravante e o sinistro.

- TJ/SP: “Apelação 0112829-94.2009.8.26.0005, 25ª Câmara de Direito Privado, Dj 19/12/2011: Seguro de veículo - Ação de reparação de danos materiais e morais - A autora recusou-se a fazer exame de embriaguez no tempo oportuno - Houve ingestão de bebida alcoólica com presunção do agravamento do risco mormente diante das peculiaridades do caso concreto. A pessoa a quem a presunção desfavorece suporta o ônus de demonstrar o contrário, independentemente de sua posição processual, nada importando o fato de ser autor ou réu. Hipótese de excludente de responsabilidade contratual por parte da seguradora Recurso não provido".

- TJ/RS: “Apelação 9122488-28.2005.8.26.0000, 26ª Câmara de Direito Privado, DJ 14/09/2011: Seguro de veiculo - Ação de indenização - Manobras arriscadas pelo condutor do veículo segurado - Causa do acidente - Agravamento do risco - Perda do direito à indenização. Os elementos dos autos indicam que o condutor do veículo realizava a manobra "cavalo de pau", dirigindo-o com excesso de velocidade, o que acarreta a perda do direito à indenização securitária, pelo agravamento do risco."

- TJ/RS: "Embargos Infringentes No 70043858521, 3º Grupo de Câmaras Cíveis, DJ 05/08/2011): Embargos Infringentes. Cobrança. Seguro de transporte de valores. Descumprimento de cláusula contratual. Agravamento do risco contratado. Indenização indevida. Código de defesa do consumidor. 1. Mesmo considerando aplicáveis as disposições contidas no CDC à hipótese em liça, porquanto a empresa contratante do seguro é a destinatária final do produto, não se constata qualquer infringência às normas contidas na legislação consumerista. Cláusula restritiva redigida de forma apropriada, com clareza e precisão. 2. Agravamento do risco caracterizado, pois a autora descumpriu voluntariamente a cláusula de gerenciamento de risco, que impunha mais de um portador para o transporte de valores até $\mathrm{R} \$ 12.000,00$, e pelo menos dois portadores armados para o transporte de valores até $\mathrm{R} \$ 50.000,00$. A cláusula contratual que limita os direitos não é nula pelo simples fato de estabelecer deveres ao contratante. Embargos infringentes desacolhidos, por maioria." 
Tampouco é necessário que o risco seja imputável à conduta do segurado para surtir

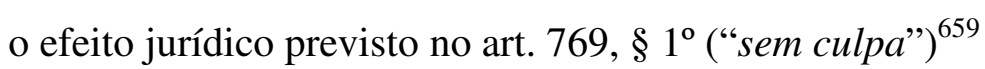

Essa interpretação jurisprudencial, além de desconsiderar o mecanismo do seguro, trai a finalidade da lei, que, no caso, é preservar a proporcionalidade risco-prêmio no curso do contrato. E probabilidade é sempre virtual, porque efetivo é o sinistro, que não tem relação necessária com a agravação, a qual pode provocá-lo, ou não.

O exame da legislação estrangeira é útil para demonstrar que o agravamento do risco independe do sinistro. Com exceção do regime jurídico alemão, ${ }^{660}$ todos os demais sistemas legais do mundo ocidental assumem posição consentânea com a ora sustentada, respeitando os princípios que norteiam o instituto do seguro e atendendo ao mecanismo da operação subjacente.

O último parágrafo do art. 1898 , do Código Civil italiano ${ }^{661}$, sobre o qual foi calcada a nossa lei civil, é suficiente para esclarecer que o agravamento do risco independe

\footnotetext{
${ }^{659}$ Nestes dois casos seguintes, a decisão descarta a agravação do risco, sob o argumento de que não seria imputável à conduta do segurado. Em primeiro lugar, o agravamento pode ocorrer sem culpa do segurado, e, ainda assim, surtir o efeito previsto no art. $769, \S 1^{\circ} \mathrm{CC}$. Como a seguradora, via de regra, só descobre o agravamento do risco com a notícia do sinistro, poderia exercer seu direito a resolver o contrato, nos termos do dispositivo citado, a despeito de já ter ocorrido o sinistro. Lamenta-se que a péssima redação da lei exija do juiz conhecimento mais profundo da operação de seguros para poder aplicá-la sem afrontar a natureza do instituto, levando em conta possibilidade de a seguradora exercer seu direito de resolver o contrato, desde que o faça nos termos da lei. Irrelevante quanto a este aspecto a relação ser considerada de consumo ou não.

- STJ: “AgRg no REsp 1173139/SP, Rel. Min. Massami Uyeda, 3a Turma, DJE 18/05/11: Agravo Regimental no Recurso Especial - Ação de Cobrança - Seguro de automóvel - Embriaguez de terceiro condutor (filho do segurado) como causa determinante do sinistro - Fato não imputável à conduta do segurado - exclusão da cobertura - Impossibilidade - Acórdão Recorrido em desacordo com o entendimento desta corte - Recurso Improvido.

${ }^{660}$ Ressalve-se que a autodisciplina e o rigor na observância da lei e da ordem, características preponderantes do contexto sócio-cultural alemão, não guardam semelhança com nosso ambiente institucional, cujas normas sociais são condescendentes e flácidas, exigindo mais austeridade do Direito, porque, na função balizadora da interação entre os agentes, as regras formais suprem as informais, como observaram Luhmann e North.

${ }^{661}$ Art. 1898. Aggravamento del rischio.

Il contraente ha l'obbligo di dare immediato avviso all'assicuratore dei mutamenti che aggravano il rischio in modo tale che, se il nuovo stato di cose fosse esistito e fosse stato conosciuto dall'assicuratore al momento della conclusione del contratto, l'assicuratore non avrebbe consentito l'assicurazione o l'avrebbe consentita per un premio più elevato.

L'assicuratore può recedere dal contratto, dandone comunicazione per iscritto all'assicurato entro un mese dal giorno in cui ha ricevuto l'avviso o ha avuto in altro modo conoscenza dell'aggravamento del rischio.

Il recesso dell'assicuratore ha effetto immediato se l'aggravamento è tale che l'assicuratore non avrebbe consentito l'assicurazione; ha effetto dopo quindici giorni, se l'aggravamento del rischio è tale che per l'assicurazione sarebbe stato richiesto un premio maggiore.

Spettano all'assicuratore $i$ premi relativi al periodo di assicurazione in corso al momento in cui è comunicata la dichiarazione di recesso.

Se il sinistro si verifica prima che siano trascorsi i termini per la comunicazione e per l'efficacia del recesso, l'assicuratore non risponde qualora l'aggravamento del rischio sia tale che egli non avrebbe consentito l'assicurazione se il nuovo stato di cose fosse esistito al momento del contratto; altrimenti la somma dovuta è ridotta, tenuto conto del rapporto tra il premio stabilito nel contratto e quello che sarebbe stato fissato se il maggiore rischio fosse esistito al tempo del contratto stesso. (grifo nosso).
} 
da ocorrência do sinistro, indicando que não tem fundamento a exigência jurisprudencial do nexo causal entre um e outro. Ao estabelecer que, "se o sinistro ocorrer antes da expiração dos prazos de comunicação e da eficácia do cancelamento, a seguradora não responde pela indenização, se o agravamento do risco for tal que com ele não teria consentido na celebração do contrato", a lei italiana comprova que o foco da norma é a relação risco-prêmio. Nada a ver com o sinistro, portanto.

Antonio Latorre, na obra dedicada ao contrato de seguro, observa que os efeitos do agravamento do risco (art. $1898 \mathrm{CC}$ ) operam independentemente de sua influência sobre o sinistro, ao estabelecer o direito do segurador de resolver o contrato ${ }^{662}$.

A doutrina francesa ${ }^{663}$ também considera a proporcionalidade risco-prêmio como fundamento da norma que estabelece as consequências jurídicas do agravamento do risco, e, por isso, toda modificação de um elemento essencial do contrato, principalmente se concernente ao risco, deve ser vista como uma novação ${ }^{664}$. Não basta que o risco seja perfeitamente definido na conclusão do contrato, é preciso ainda que as circunstâncias aptas a alterar a relação risco-prêmio durante a execução contratual, provocadas ou não pelo segurado, sejam comunicadas ao segurador, que poderá alterar as condições do contrato de acordo com as novas circunstâncias ou resolvê-lo, se insuperável o desequilíbrio por estas provocado ${ }^{665}$.

Não é sem razão que a legislação e a doutrina estrangeiras prestigiam o princípio da proporcionalidade e a manutenção da proporção risco-prêmio durante toda a vigência do contrato. Sua interpretação é consentânea com a compreensão do mecanismo da operação econômica subjacente ao contrato de seguro.

O Código Civil anterior ${ }^{666}$ resolvia muito melhor a questão, porque, demonstrado o agravamento, não era necessário comprovar a intenção do segurado, bastaria que tivesse sido provocado por ação ou omissão dele. Isto contribuía para evitar o moral hazard, que abrange condutas movidas por dolo e culpa.

\footnotetext{
${ }^{662}$ LA TORRE, Antonio (a cura di). Le assicurazioni, cit., p. 565. Coerentemente, o autor não arrola o sinistro dentre os requisitos do agravamento para produzir efeitos sobre o contrato. Id. Ibid., p. 114.

${ }^{663}$ COUILBAULT, François; ELIASHBERG, Constant; LATRASSE, Michel. Les grands principes de l'assurance. 5. ed. Paris: L'Argus, 2002. p. 95-96.

${ }^{664}$ LAMBERT-FAIVRE, Yvonne. op. cit., p. 131.

${ }^{665}$ PICARD, Maurice; BESSON, André. op. cit., p. 118-119.

${ }^{666}$ Art. 1454 CC 1916. Durante a vigência do contrato, o segurado deve abster-se de tudo quanto possa aumentar os riscos, ou seja contrário aos termos estipulados, sob pena de perder a garantia do seguro.
} 
Pela lei nova, todos os demais segurados arcam com as consequências da negligência, imprudência, imperícia, e frequentemente até com o dolo do segurado, se a seguradora não conseguir demonstrar em juízo a intenção dele.

Se a regra jurídica não funciona, só serve como estímulo ao oportunismo, em prejuízo dos que se pautam pela lealdade e prestigiam a confiança inerente ao instituto do seguro. E a condescendência da legislação securitária com relação ao moral hazard criará externalidades negativas a toda a sociedade, devido à já discutida interação entre seguro e responsabilidade civil.

\section{Elementos essenciais do contrato. Interesse legítimo}

O interesse é a relação de valor entre um sujeito e determinado bem ou pessoa ${ }^{667}$. Já o focalizamos indiretamente ao abordar o risco, que, no contrato de seguro, funciona como um atributo do interesse, porque o qualifica. Por isso, não se pode tratar do risco, sem lhe fazer menção.

Mesmo quando o Código Civil anterior não se referia a interesse ao conceituar o contrato de seguro, já se constatava de que não era o bem, mas o interesse a ele relativo, o objeto do contrato de seguro ${ }^{668}$.

Porém, ainda há certa dissensão sobre a natureza jurídica do interesse, que, para uns ${ }^{669}$ é o objeto imediato da garantia, e esta é que seria objeto do contrato. O interesse seria objeto mediato do contrato. ${ }^{670}$ Para outros ${ }^{671}$, é o objeto material, qualificado pelo risco, que seria "o modo de ser do interesse". ${ }^{672}$ Sustenta-se que "o objeto de um negócio de seguro é sempre um interesse submetido a um risco" 673 . "A distinção entre o interesse segurável e a coisa ou objeto a que este interesse se refere explica o fato de que possa existir uma multiplicidade de seguros do mesmo tipo referentes à mesma coisa, com

\footnotetext{
${ }^{667}$ VAUGHAN, Emmett J.; VAUGHAN, Therese M. op. cit., p. 169.

${ }^{668}$ Como, v.g., PONTES DE MIRANDA, F. C. Tratado de direito privado: parte especial, cit., t. 45, p. 275.

${ }^{669}$ TZIRULNIK, Ernesto; CAVALCANTI, Flávio de Queiroz. B.; PIMENTEL, Ayrton. op. cit., p. 32-36.

${ }^{670}$ Mas esta distinção não parece ter efeito prático, porque os próprios autores admitem que ilicitude ou impossibilidade do interesse invalidaria o contrato, nos termos do art. 104, II, CC.

${ }^{671}$ COMPARATO, Fábio Konder. O seguro de crédito: estudo jurídico, op. cit., p. 25, MELLO FRANCO, Vera Helena de. Reflexões sobre o contrato de seguro no novo Código Civil brasileiro, op. cit. p. 444; PIZA, Paulo Luiz de Toledo. op. cit., p. 180.

${ }^{672}$ COMPARATO, Fábio Konder. O seguro de crédito: estudo jurídico, cit., p. 25, TZIRULNIK, Ernesto; CAVALCANTI, Flávio de Queiroz. B.; PIMENTEL, Ayrton. op. cit.

${ }^{673}$ COMPARATO, Fábio Konder. O seguro de crédito: estudo jurídico, cit., p. 25, MELLO FRANCO, Vera Helena de. Reflexões sobre o contrato de seguro no novo Código Civil brasileiro, cit. p. 444; PIZA, Paulo Luiz de Toledo. op. cit., p. 180.
} 
titulares diferentes". ${ }^{674}$ A titularidade do interesse protegido não se confunde, assim, com a titularidade do bem.

A garantia do seguro recai sobre o legítimo interesse de um sujeito em relação a um bem ou a uma pessoa. O interesse deve ser próprio, ter conteúdo econômico, e estar presente na formação e na conclusão do negócio jurídico. E deve ser legítimo. A legitimidade se traduz não só pela licitude, que é genericamente imposta por lei (art.104, II, CC), mas também pela possibilidade de ser o segurado atingido pelos eventuais efeitos da realização do risco.

A doutrina americana considera o interesse segurável como princípio basilar do seguro $^{675}$, que confere substância ao princípio indenitário. $\mathrm{O}$ fundamento daquele princípio é que contratos de seguro são juridicamente vinculantes somente na medida em que o segurado tem interesse no bem segurado e se tal interesse for segurável. Sua existência depende da possibilidade de sofrer prejuízo financeiro em decorrência do sinistro relacionado ao objeto do seguro ${ }^{676}$. Para Vaughan o interesse não é objeto do contrato de seguro, operando mais como um pressuposto, como se depreende do contexto, porque o texto não é explícito quanto a este aspecto.

As principais funções do interesse segurável são evitar que o seguro funcione como jogo e reduzir o moral hazard, porque se poderia segurar a propriedade ou a vida de um terceiro, apostando no sinistro, o que afrontaria a finalidade social do seguro. E se não fosse por essa relação entre o segurado e o bem ou a pessoa cujo interesse pretende segurar, haveria incentivo para que o próprio segurado provocasse o sinistro. Ele não o fará se tiver interesse legítimo em garantir o bem, porque receberá apenas o equivalente ao prejuízo resultante do sinistro. ${ }^{677}$ Essas também são funções do princípio indenitário, que será abordado adiante.

\footnotetext{
${ }^{674}$ COMPARATO, Fábio Konder. op. cit., p. 25.

${ }^{675}$ REJDA George. Principals of risk management and insurance. 10. ed. Boston, MA.: Person International Edition, 2008. p. 178.

676 "The most important legal doctrine giving substance and support to the principle of indemnity is that of insurable interest. An insurance contract is legally binding only if the insured has an interest in the subject matter of the insurance and his interest is in fact insurable. In most instances, an insurable interest exists only if the insured would suffer a financial loss in the event of damage to, or destruction of, the subject matter of the insurance." VAUGHAN, Emmett J.; VAUGHAN, Therese M. op. cit., p. 169.

${ }^{677}$ REJDA George. op. cit., p. 178.
} 


\section{Elementos essenciais do contrato. Garantia}

Seguro se traduz por garantia. Essa proteção de um interesse contra risco sobre ele incidente pressupõe a obrigação do segurador de organizar a mutualidade, administrar os recursos do fundo comum, de modo a preservar sua capacidade financeira de arcar com eventuais sinistros. É a principal prestação do segurador, que tem como contrapartida o pagamento do prêmio. Alguns autores, entretanto, ainda consideram que a contraprestação do segurador é a indenização prestada em caso de sinistro ${ }^{678}$, embora se reconheça que, como o sinistro é eventual, a indenização também é.

A garantia também suscita certa controvérsia. Para uns é o objeto imediato do contrato de seguro ${ }^{679}$. Outros não a consideram objeto do contrato, mas a prestação do segurador. A cobertura securitária é a garantia prestada pelo segurador contra riscos a que está sujeito o grupo de segurados e que poderia afetar o patrimônio de qualquer um deles $^{680}$.

Salvo se houver prazo de carência, a garantia é prestada a partir da aceitação da proposta, ou do decurso do respectivo prazo, mesmo antes da data de vencimento para o pagamento do prêmio. Mas poderá ser suspensa em caso de mora do segurado.

A garantia comporta algumas modalidades, como, por exemplo, a franquia e o descoberto obrigatório, cuja função precípua é prevenir o moral hazard, pois são formas de partilhar o risco com o próprio segurado, incentivando-o a zelar melhor pelo interesse garantido.

Reitere-se o que já foi dito a propósito da predeterminação dos riscos, que se reflete nos limites da garantia, os quais não podem ser estendidos além do convencionado. A inclusão de risco não estipulado desfigura o contrato, transformando-o em jogo ou aposta, como no caso da extensão indevida do risco garantido para abranger dano moral não previsto no contrato, nos casos de seguro de responsabilidade civil, que garante o risco de diminuição patrimonial do segurado por força de ter que indenizar terceiro, com fundamento no art. 186, do Código Civil.

\footnotetext{
${ }^{678}$ PICARD, Maurice; BESSON, André. op. cit., p. 45.

${ }^{679}$ TZIRULNIK, Ernesto; CAVALCANTI, Flávio de Queiroz. B.; PIMENTEL, Ayrton. op. cit., p. 30.

${ }^{680}$ MELLO FRANCO, Vera Helena de. Contratos: direito civil e empresarial, cit. A autora entende que a prestação de garantia é ônus do segurador, que seria uma relação de sujeição, como a obrigação, mas, ao contrário desta, não lhe pode ser exigida judicialmente pelo segurado. O pagamento da indenização seria uma obrigação, ainda que eventual do segurador. Lições de Direito Securitário, p. 57.
} 


\section{Elementos essenciais do contrato. Prêmio}

Como contraprestação do segurado pela garantia, o prêmio ${ }^{681}$ também é elemento essencial do contrato. Resulta do cálculo do valor do risco incidente sobre o interesse protegido. É a representação pecuniária do risco. Há entre ambos uma correlação necessária, que é expressão do princípio da proporcionalidade do prêmio ao risco ${ }^{682}$. Daí decorre a importância da prévia determinação e mensuração do risco, que é a medida para o cálculo do prêmio, e se reflete na formação do fundo comum. E justamente em função da composição desse fundo, aplica-se também o princípio da indivisibilidade do prêmio, que é devido no início da vigência contratual em consideração da garantia prestada a partir da aceitação do contrato. Excepcionalmente comporta redução, na hipótese de diminuição significativa do risco (art. $770 \mathrm{CC}$ )

O prêmio puro corresponde ao valor teórico do risco, calculado de acordo com a probabilidade de ocorrência do sinistro, e sua possível intensidade ${ }^{683}$. É a resultante da ponderação de todos os elementos que possam incidir, favorável ou negativamente, no comportamento do risco ${ }^{684}$

Ao prêmio puro são acrescidas somas correspondentes a tributos, taxas de administração e despesas operacionais, além das reservas técnicas exigidas por lei ${ }^{685}$. São denominados carregamentos no jargão securitário, formando o chamado prêmio comercial $^{686}$.

O conjunto dos prêmios pagos pelos segurados, cujos riscos foram agrupados, comporá o fundo comum, que garantirá as indenizações eventualmente devidas a integrantes do grupo. Por isso, considerada a função do fundo comum, o inadimplemento da obrigação do segurado assume proporção muito maior do que em um contrato isolado.

\footnotetext{
${ }^{681}$ Nas associações mútuas o preço do risco é chamado cotização.

${ }^{682}$ PICARD, Maurice; BESSON, André. op. cit., p. 38 e 41.

${ }^{683}$ Id. Ibid., p. 39.

${ }^{684}$ Embora abordado no capítulo anterior, reiteramos aqui uma síntese do cálculo do prêmio puro. "Para chegar à probabilidade de sinistros, faz-se o levantamento estatístico, num dado período de tempo, da incidência das ocorrências em relação ao total de casos analisados. A estatística parte da análise da freqüência e intensidade de ocorrências passadas para, com base nos resultados apurados estabelecer matematicamente as probabilidades de novas ocorrências. Essas probabilidades são expressas sob forma de fração, cujo numerador exprime os fatos ocorridos (chances favoráveis) e o denominador, os casos observados (chances possíveis). Se as estatísticas revelarem, por exemplo, que de 1000 casos analisados por ano, registraram-se 5 ocorrências, a probabilidade será de 5/1000 (cinco por mil). Este será, então, o índice aplicado ao prêmio puro". ALVIM, Pedro. op. cit., p. 271.

${ }^{685}$ Id. Ibid., p. 272.

${ }^{686}$ LAMBERT-FAIVRE faz outra distinção: o prêmio puro acrescido dos carregamentos comerciais resulta no prêmio líquido ou comercial, ao qual é somado o carregamento tributário, compondo o prêmio total. LAMBERT-FAIVRE, Yvonne. op. cit., p. 214-215.
} 


\section{A mora do segurado}

A mutualidade não permite, como argumentamos, que o contrato de seguro seja analisado isoladamente, sob pena de se perder de vista a sua essência, que é a de garantia recíproca.

Para atender à função de assegurar a proteção do grupo de segurados, a seguradora reúne uma comunidade de riscos homogêneos, que serão enfrentados com os recursos comuns. Daí por que a mora do segurado não pode ser relevada, na aplicação do art. 763, CC.

Desconsiderar a mora representa desestímulo ao cumprimento pontual da obrigação, o que afronta uma das principais funções do Direito Contratual, que é assegurar o comprometimento das partes e o cumprimento dos contratos. Mas, neste caso, dadas as peculiaridades do contrato de seguro, os efeitos do descumprimento contratual extrapolam a relação bilateral segurado-segurador, pois se refletem na comunidade de segurados.

Ademais, relevar a mora do segurado, permitindo-lhe que pague o prêmio após a indenização do sinistro que o atingiu, desnatura o contrato de seguro, já que o prêmio é a contrapartida da garantia, e não da indenização pelos danos provocados pela materialização do risco.

A norma do art. $763^{687} \mathrm{CC}$ firmou, como ressalta Vera H. M. Franco, “o entendimento correto de que a condição para o recebimento da indenização é o pagamento tempestivo do prêmio, quer ocorra antes, quer depois do sinistro". ${ }^{68}$ E o teor do dispositivo não dá margem a dúvida: se o segurado estiver em mora no pagamento do prêmio e o sinistro ocorrer antes de sua purgação, não fará jus à indenização. Trata-se de suspensão do direito à garantia, até a purgação da mora, e, uma vez quitado o débito atrasado, o contrato retoma a vigência. Portanto, não haveria por que cogitar-se aqui de resolução do contrato como sanção da mora do segurado ou como opção do segurador, pois a lei não suscita esta hipótese. A mora ora referida é a ex re, pois a lei dispõe que "o inadimplemento da obrigação positiva e líquida, no seu termo, constitui de pleno direito a mora do devedor" (art. 397 CC). E, no caso, não há por que considerar que se trataria de mora ex persona. Nem mesmo a aplicação do Código do Consumidor, se e quando cabível, poderia dar

\footnotetext{
${ }^{687}$ Art. 763. Não terá direito a indenização o segurado que estiver em mora no pagamento do prêmio, se ocorrer o sinistro antes de sua purgação.

${ }^{688}$ MELLO FRANCO, Vera Helena de. Reflexões sobre o contrato de seguro no novo Código Civil brasileiro, cit., p. 443-451.
} 
ensejo a essa interpretação, pois sancionar a mora não pode ser considerado abusivo, mormente se consideradas as peculiaridades do contrato de seguro.

A jurisprudência do Superior Tribunal de Justiça, ainda sob a égide do Código Civil anterior, exigia inicialmente que a seguradora tivesse proposto ação de resolução do contrato contra o segurado inadimplente, como se a lei tivesse tratado de resolução e exigido este requisito. A exigência do pré-requisito foi mitigada, segundo o Min. Aldir Passarinho, que, considerando a dificuldade de se impor à seguradora que ingressasse com ação resolutória a cada atraso de pagamento, o que equivaleria a impedi-la de exercer seu direito de defesa, reduziu a exigência à interpelação prévia do segurado em atraso. ${ }^{689}$

Esta orientação jurisprudencial se disseminou, transformando a mora ex re em mora ex persona. E, por incrível que pareça, subsistiu à alteração do regime, a despeito da clareza do texto legal vigente, que impôs, como condição para o recebimento da indenização, o pagamento tempestivo do prêmio.

Tanto a interpretação anterior como essa são contra legem, como salienta Alves Pereira $^{690}$, pois a exigência atual desconsidera o fato de que o pagamento do prêmio é obrigação positiva e líquida, e, portanto, exigível independentemente de interpelação do devedor. Interpretação diversa afronta a norma do art. 397 CC. O mais paradoxal é que essa afronta parte da mesma Corte encarregada pela Constituição Federal de apreciar os casos de violação à lei federal, que ela aqui transgride. As decisões judiciais contra legem constituem grave fator de insegurança jurídica.

Depois a jurisprudência passou a adotar a teoria do adimplemento substancial, inspirado em certa doutrina americana, mas mal adaptável ao contrato de seguro, cuja natureza e função não comportam elucubrações a respeito do montante do inadimplemento. E paralelamente a jurisprudência manteve a exigência da interpelação como condição para a suspensão da garantia.

Diante do inadimplemento do prêmio por mais de um ano, o Superior Tribunal de Justiça passou a entender, com o Min. Humberto Gomes de Barros, que o descumprimento da obrigação do segurado por tempo muito prolongado daria ensejo à resolução do contrato sem prévia interpelação ${ }^{691}$.

\footnotetext{
${ }^{689}$ REsp. n. 316.449-SP (2001/0039404-6), j. 09.10.2002.

${ }^{690}$ PEREIRA, Antonio Carlos Alves. Miragens e aproximação. Revista Brasileira de Direito do Seguro e da Responsabilidade Civil, São Paulo, p. 95-112, jan. 2009.

${ }^{691}$ REsp. n. 842.408-RS, j. 16/12/2006.
} 
Essa dinâmica jurisprudencial suscitou a crítica traçada por Alves Pereira, que a resumiu com merecida ironia, dizendo que "a mora considerada a princípio ex persona converter-se-ia em mora ex re pelo decurso do tempo." 692

À evidência de que os integrantes do Superior Tribunal de Justiça, bem como os das outras Cortes, sabem a diferença entre mora ex re e ex persona, a criação dessa esdrúxula 'teoria da mora' em afronta à norma do art. 763, só pode ter uma explicação: decorreu de analogia com os casos em que, a despeito de serem de mora ex re, a lei exige interpelação prévia. Em muitos desses casos excepcionais, diga-se de passagem, foi a jurisprudência que incitou a positivação da exceção, como no caso do compromisso de compra e venda ${ }^{693}$. Então, essa analogia, de certa forma, se explica. Mas evidentemente não se justifica, primeiro, porque só a lacuna legal comportaria analogia, e, depois, mesmo em se considerando que a atividade jurisdicional eventualmente pode criar lei ao interpretá-la, a orientação jurisprudencial se revela absolutamente incompatível com a natureza e a função do contrato de seguro.

E nem se invoque a função social, outra panacéia para todos os males, porque a verdadeira função social do contrato de seguro é exatamente a dispersão dos riscos que seriam insuportáveis para um indivíduo, mas que, socializados, i.e., diluídos na mutualidade, serão perfeitamente suportáveis, por meio dos recursos do fundo comum, que, por isso mesmo têm que ser quitados tempestivamente pelos segurados. Nada mais social do que esta função do seguro: um por todos e todos por um.

Portanto, essa interpretação esdrúxula da lei afronta não só a verdadeira função social do contrato de seguro, como também a função social do Direito, que é incentivar o comprometimento e a cooperação das partes, desestimulando o descumprimento das obrigações pactuadas.

\footnotetext{
${ }^{692}$ PEREIRA, Alves. op. cit., p. 75.

${ }^{693}$ Mas hoje, essa benevolência em relação ao compromissário comprador, que data de mais de meio século, se afigura anacrônica e descabida, porque todos, independentemente da classe social e do nível de educação, demonstram ter suficiente discernimento para saber que o pagamento tempestivo das parcelas dos carnês - tão conhecidos por promoverem sorteios - é condição indispensável para que o cliente sorteado receba o prêmio. Ora, se isto é inteligível para qualquer espectador de canal aberto, ou seja, a mídia acessível desde o mais iletrado até o mais ilustrado dos cidadãos, porque não seria compreensível para o segurado a condição de tempestividade no pagamento do prêmio para o recebimento de eventual indenização? E, em sendo inteligível esta exigência, por que relevar o atraso? A ironia, no caso, é que essa condescendência incentivará a mora do segurado, que terá, assim, recursos para manter em dia o pagamento de seus carnês.
} 


\section{Estrutura do Contrato de Seguro. Elementos acidentais}

O sinistro e a indenização são elementos acidentais, porque sua ocorrência é eventual e deles não depende a validade ou a eficácia do contrato.

\section{Elementos acidentais. Sinistro e Indenização}

O sinistro corresponde à concretização do risco a que está exposto o interesse segurável.

Só será indenizável se não decorrer da vontade do segurado, e deve ser comunicado ao segurador com a máxima presteza. O dever de informar aqui é permitir que a seguradora, se for o caso, minimize ou estanque os efeitos lesivos do evento. A exigência imposta ao segurado de tomar providências para minorar as consequências do sinistro decorre da presunção da legitimidade de seu interesse.

Na hipótese de sinistro total no seguro de danos, a avaliação do prejuízo para fins de indenização toma por base o valor objetivo do bem segurado, no momento do evento ${ }^{694}$, variando conforme o bem se destine ao comércio ou não. Se for destinado à venda, o critério de avaliação será o valor de mercado à data do sinistro, mas, se não, leva-se em consideração o preço de mercado, descontada a depreciação decorrente do uso ${ }^{695}$.

Se o dano for parcial, aplicam-se dois métodos de avaliação, segundo Picard e Besson: podem-se avaliar diretamente as avarias, como geralmente se faz em relação a bens móveis em caso de sinistro de pequena monta. Mas se o custo dos danos superar o valor do interesse segurado, este será o limite da indenização ${ }^{696}$. Conforme explicam os autores, o fundamento deste critério é o princípio indenitário, pois, como o segurado não está obrigado a reparar o bem avariado, o recebimento de valor maior do que o segurado representará enriquecimento indevido, se ele optar por comprar bem semelhante ao sinistrado, lucrando a diferença ${ }^{697}$.

A indenização é prestação eventual do segurador. Sua principal obrigação é a garantia de cobertura de um interesse sujeito a risco, que implica as providências que devem ser tomadas para viabilizar a pulverização do risco e o eventual pagamento da indenização, como organização da mutualidade e constituição das reservas. Somente diante

\footnotetext{
${ }^{694}$ PICARD, Maurice; BESSON, André. op. cit., p. 410.

${ }^{695}$ Id. Ibid., p. 411.

${ }^{696}$ Id. Ibid., p. 415.

${ }^{697}$ Id. Ibid., p. 416.
} 
da ocorrência do sinistro surge, em princípio, a obrigação de indenizar, condicionada aos termos da lei e do contrato ${ }^{698}$.

O pagamento da indenização dependerá da ocorrência involuntária do sinistro, nos termos contratualmente previstos, do nexo causal entre o evento e o dano resultante, e do cumprimento dos deveres legais e obrigações contratuais pelo segurado ${ }^{699}$. Preenchidos estes requisitos, o segurador deve pagar a indenização em dinheiro, se não convencionada a reposição da coisa (art. 776, CC). O atraso no pagamento acarretará correção monetária e juros moratórios (art. 772, CC)

A indenização tem a finalidade de reparar os prejuízos financeiros sofridos pelo segurado, em razão da realização do risco incidente sobre seu interesse. Por aplicação do princípio indenitário, o segurado tem direito à indenização dos danos somente até o limite $\operatorname{destes}^{700}$. Portanto, o montante indenizatório não pode ser superior ao prejuízo experimentado pelo segurado, a despeito do maior valor da garantia, pois a função do seguro não é propiciar lucro ao segurado em razão da ocorrência do sinistro ${ }^{701}$.

Argumenta Tzirulnik que, se o valor da garantia for superior ao valor do prejuízo, a prestação devida pela seguradora não equivale àquele, sob pena de afrontar a função social do contrato de seguro, que é a garantia mútua de reparação de prejuízos eventualmente sofridos em decorrência da realização do risco a que está exposto o interesse segurado. ${ }^{702}$ Para assegurar a função sócio-econômica do seguro, o princípio indenitário tem duas finalidades imediatas e conexas entre si: evitar que o seguro se transforme em aposta e reduzir o moral hazard, porque, se o segurado pudesse auferir lucro à custa do sinistro, teria incentivo a provocá-lo ${ }^{703}$.

\footnotetext{
${ }^{698}$ MELLO FRANCO, Vera Helena de. Contratos: direito civil e empresarial, cit. p. 303-304.

${ }^{699}$ Id. Ibid., p. 303.

${ }^{700}$ LAMBERT-FAIVRE, Yvonne. op. cit., p. 249-250.

${ }^{701}$ VAUGHAN, Emmett J.; VAUGHAN, Therese M. op. cit., p. 169.

${ }^{702}$ TZIRULNIK, Ernesto; CAVALCANTI, Flávio de Queiroz. B.; PIMENTEL, Ayrton. op. cit., p. 100.

${ }^{703}$ REJDA George. op. cit., p. 175.
} 


\section{CAPÍTULO 8. DEVER DE INFORMAR NO CONTRATO DE SEGURO}

Como o mecanismo da operação de seguros depende do processamento estatístico e atuarial dos dados fornecidos pelo proponente para a identificação e avaliação do objeto do contrato, exige que a informação a este pertinente seja tão perfeita quanto possível.

A par disso, a contratação em massa, com a consequente padronização dos contratos e impessoalidade dos agentes, e a reunião de recursos comuns em função da prestação de garantias recíprocas, são circunstâncias que favorecem comportamentos oportunistas $^{704}$, e justificam a instituição da máxima boa-fé, como princípio regente de tais relações, o qual, aplicado a este contexto, se traduz por transparência e lealdade. E isso se resume no dever de informar a verdade.

\section{Omissões e inexatidões como atributos do risco}

Se, de acordo com a já citada observação de North, o valor das trocas econômicas equivale ao dos atributos de seu objeto, as informações a este pertinentes são atributos seus, e passam a integrar-lhe o núcleo ${ }^{705}$. Portanto, a informação essencial concernente ao objeto do contrato é indissociável de sua essência. Isto não significa que a informação seja mais um elemento essencial do contrato de seguro, mas atributo inerente e indispensável

\footnotetext{
${ }^{704}$ Em recente artigo, Mackaay traduz com clareza o sentido do comportamento oportunista: l'opportunisme peut consister à amener une personne à conclure un accord auquel n'aurait pas volontairement consenti étant complètement informée, ou à entrer en négociation sans réelle intention de conclure un contrat, ou encore à rompre des négociations onéreuses qui sont sur le point d'aboutir à un accord (opportunism ex ante). L'opportunisme peut aussi viser à exploiter des circonstances imprévues pour lesquelles le contrat ne comporte pas de règles explicites, afin de tourner la division des gains du contrat implicitement convenue au moment de da conclusion de l'accord (l'opportunism ex post). Pour employer le langage de la théorie des jeux, dans un dilemme du prisonnier, l'opportuniste opte pour la défection alors que les autres joueurs choisissent la coopération. La partie qui agit de manière opportuniste exploite une asymétrie dans le rapport au détriment des autres parties. MACKAAY, Ejan. L'analyse économique du droit comme outil de la doctrine juridique: la bonne-foi et la justice contractuelle. Texto referente à palestra apresentada no IV Congresso da Associação Brasileira de Direito e Economia em Curitiba, 2011.

- Muris apontou uma das características mais perversas do oportunismo, a sutileza, típica da fraude, pois a ilicitude do comportamento é difícil de detectar, porque geralmente vem mascarado por uma atividade legítima, e só se pode detectá-lo a um custo elevado: In general, opportunistic behavior is subtle in two ways: first, the behavior is inherently difficult to detect; second, although the activity is detectable, it is easily masked as legitimate conduct, and thus its opportunistic nature is discoverable only at a high cost. MURIS, Timothy J. Opportunistic behavior and the law of contracts. Minnesota Law Review, v. 65, p. 526, 1980-1981. Ressalve-se apenas a discordância em relação à afirmação de Muris de que o oportunismo só ocorre depois da conclusão do contrato.

${ }^{705}$ Discutimos este aspecto no capítulo 1 , no tópico referente à função e a importância da informação que instrui o contrato.
} 
àquele ao qual se refere. Esta é a relação de pertinência entre as informações prestadas pelo proponente e o risco, que, por sua vez, define os limites da garantia e o montante do prêmio.

Para avaliar as probabilidades de risco e aquilatar a conveniência do contrato, o segurador contará com recursos estatísticos, regras de experiência e com as declarações do segurado, que, no entanto, não tem incentivos para revelar todas as condições ou características do risco a que está sujeito seu interesse, porque o preço da garantia aumenta proporcionalmente à probabilidade e intensidade do risco. Este é o aspecto da assimetria informacional sempre subestimado na interpretação e na aplicação da lei.

No contrato de seguro, as informações relevantes pertinentes ao risco são as que permitem identificá-lo e mensurá-lo e que podem, de alguma forma, influenciar sua aceitação, ou não, pelo segurador. Por isso a lei exige que a emissão da apólice seja precedida de proposta escrita com a declaração dos elementos essenciais do interesse a ser garantido e do risco a que está sujeito (art. 759, CC). A razão disso é que a informação pertinente ao risco integra esse elemento essencial do contrato de seguro. Daí a sua importância em relação a esta operação.

Como a avaliação do risco depende das informações fornecidas pelo proponente, omissões e inexatidões de suas declarações distorcerão os cálculos. Isto poderá induzir o segurador a um consentimento viciado ou romper a proporcionalidade entre risco e prêmio, onerando os recursos comuns em detrimento do grupo todo.

\section{Origem do dever de informar no seguro}

O direito inglês, que cunhou a expressão utmost good faith, é tradicionalmente rigoroso em relação à disciplina da informação no contrato de seguro. Embora reconheça a reciprocidade do dever de informar, sua exigência se concentra nas informações do segurado, em razão da potencialidade nociva da assimetria informacional desfavorável ao segurador.

As bases da aplicação do princípio uberrima fides e sua aplicação ao contrato de seguro foram traçadas na decisão de Lord Mansfield no caso Carter v. Boehm, em 1766. Tratava-se de seguro contra risco de captura do Fort Marlborough, em Sumatra. Depois da rendição aos franceses, o governador do forte (Carter) pleiteou indenização, que foi recusada. Em juízo, a seguradora alegou omissão de informações relevantes relacionadas à 
iminência do ataque francês e às condições construtivas do forte, que o expunham a maior probabilidade de sucumbir a ataques inimigos. Apesar de ter acolhido a pretensão do segurado, considerando que a preparação do ataque francês, embora conhecida deste, era segredo militar e que o fato notório de ter sido contratado o seguro imediatamente antes da assunção do cargo na ilha já indicaria a gravidade do risco, a decisão de Lord Mansfield representa o marco inaugural do princípio da utmost good faith. ${ }^{706}$ Tratando obiter dicta do dever de informar, o juiz invocou a uberrima fides, erigindo-a a princípio orientador do contrato de seguro. Na fundamentação, aborda a reciprocidade e o alcance do dever de informação, e a prescindibilidade da apreciação do elemento subjetivo, argumentando que a omissão caracteriza fraude ipso facto e acarreta a anulação do contrato se o risco efetivo for diferente do risco coberto ${ }^{707}$.

Depreendem-se do teor da fundamentação as premissas que orientam o princípio da máxima boa-fé na sua origem:

a) obrigação de prestar à contraparte informações relevantes relativas ao risco, em razão da percepção da necessidade de confiança recíproca ditada pelo papel do risco no contrato de seguro;

b) reciprocidade do dever de informação;

c) dados omitidos ou distorcidos devem ser conhecidos do segurado à data da contratação e desconhecidos do segurador.

d) irrelevância do intuito fraudulento da omissão ou distorção, pois a fraude é ínsita nestas condutas;

e) descumprimento do dever de informar acarreta rescisão como opção do segurador;

\footnotetext{
706 "Insurance is a contract upon speculation. The special facts, upon which the contingent chance is to be found, lie more commonly in the knowledge of the insured only: the underwriter trusts to his representation, and proceeds upon confidence that he does not keep back any circumstance in his knowledge, to mislead the underwriter into a belief that the circumstance does not exist and to induce him to estimate the risk as if it did not exist. The keeping back of such a circumstance is a fraud and therefore the policy is void. Although the suppression should happen through mistake, without fraudulent intention; yet still the underwriter is deceived, and the policy is void; because the risk run is really different from the risk understood and intended to be run at the time of the agreement'. (1766) 3 Burr. 1905, p. 1909-1910.

707 "The policy would be equally void, against the underwriter, if he concealed; if he ensured a ship on her voyage, which he privately knew to be arrived: and an action would lie to recover the premium... Good faith forbids wither party by concealing what he privately knows, to draw the other into a bargain, from his ignorance of that fact, and his believing the contrary (...). This definition of concealment, (...) will generally hold to make it void, in favour of the party misled by his ignorance of the thing concealed". (1766) 3 Burr. 1905, p. 1909-1910.
} 
Desde então, o dever de informar no contrato de seguro tem sido a expressão primordial da utmost good faith e ainda subsistem, no direito britânico, os fundamentos lançados na decisão de Mansfield.

Mas o fato de ter surgido como emanação da máxima boa-fé não distingue a essência do dever de informar no contrato de seguro e no direito contratual em geral, já que este também emana da boa-fé. São ontologicamente iguais, pois ambos se pautam pelos mesmos ditames, e as variações se devem a circunstâncias da operação subjacente a cada contrato. A diferença entre um e outro reside apenas na intensidade da assimetria informacional e na menor ou maior gravidade de seus efeitos, mais severos no contrato de seguro devido a idiossincrasias do instituto, justificando a exigência de estrita boa-fé, que não permite ao intérprete desconsiderar o requisito de máxima transparência e veracidade.

\section{Natureza do dever de informar no contrato de seguro}

O dever de informar no âmbito dos seguros privados tem caráter recíproco. Impõese ao segurado em função da referida disparidade informacional que o favorece em detrimento da contraparte e da mutualidade, e do incentivo que ele tem para ocultar informações a respeito do risco, em razão da proporcionalidade risco-prêmio ${ }^{708}$. Ao segurador também se exige transparência e veracidade, especialmente em relação aos termos usados no contrato, à clareza e objetividade das cláusulas, de modo que seu teor seja compreensível à contraparte ${ }^{709}$.

Como corolário da máxima boa-fé, que é da essência do contrato de seguro, o dever de informar deve ser estritamente cumprido, sob pena de desnaturar o instituto. A ratio do controle da informação nesse tipo contratual é a tutela da confiança, também presente nos vícios de consentimento e nas obrigações em geral, e o maior rigor do seu regime decorre das peculiaridades da operação subjacente.

Desde o século XIX se discute se sua natureza jurídica seria de obrigação contratual, porque emerge das características inerentes do contrato de seguro, ou dever legal, regra imposta por lei não derivada exclusivamente dos termos implícitos no contrato, porque comum a todos os contratos uberrimae fidei.

\footnotetext{
${ }^{708}$ A lei expressamente prevê a perda do direito à garantia, no caso de a omissão ou inexatidão ter sido cometida pelo representante do segurado, pois age em nome e por conta deste.

${ }^{709}$ Embora, como já observamos, a predisposição das cláusulas do contrato de seguro não fiquem ao alvedrio do segurador, devido à estrita regulação desse mercado, exige-se clareza das cláusulas, especialmente nas concernentes à limitação de riscos, de modo que sejam inteligíveis para o aderente.
} 
A diferença de aplicação entre as teorias concerne aos efeitos do descumprimento. Se decorrente do contrato, significaria inadimplemento de obrigação, autorizando rescisão e indenização por prejuízos eventualmente causados à contraparte. Se decorrente da lei, a quebra do dever implicará as consequências legalmente previstas. A doutrina tende a considerá-lo dever legal, seja em relação ao direito contratual em geral ${ }^{710}$, seja em relação ao contrato de seguro ${ }^{711}$. O argumento comum é que, nascendo antes da conclusão do contrato, este não poderia ser sua fonte.

A teoria da origem contratual perdeu força no Reino Unido no século XX, a partir da vigência da legislação especial de seguros (Marine Insurance Act de 1906), que impôs expressamente o dever de informar (art. 18) e cuja aplicação se estendeu também aos seguros terrestres.

Posteriormente surgiu, inspirada no direito americano, outra teoria que considera a relação fiduciária existente entre as partes como fundamento do dever de informar ${ }^{712}$. E, de fato, este é instrumento de tutela da especial confiança exigida no contrato de seguro. Mas, adotando interpretação mais restrita de relação fiduciária ${ }^{713}$, entendemos que assim se classificam apenas aquelas em que uma parte tem obrigação contratual de zelar pelos interesses da outra em detrimento dos seus próprios, como, por exemplo, no mandato ou na administração societária, e esse não é o caso do segurado e segurador.

Adequada, pois, a classificação como dever legal.

\section{Objeto do dever de informar em matéria de seguro}

O objeto do dever de informar são fatos (e não opiniões) relevantes em relação ao risco (material facts).

\footnotetext{
${ }^{710}$ Assim, por exemplo, ROPPO, Vincenzo. Il contratto, cit., p. 177-179. BIANCA, C. Massimo. op. cit., p. $162-163$.

${ }^{711}$ SEFTON-GREEN, Ruth (Ed.). op. cit., p. 24-25. PARK, Semin. The duty of disclosure in insurance contract law. Dartmouth Publishing Company, 1996. p. 48-49 e 54.

${ }^{712}$ PARK, Semin. op. cit., p.48-49.

Esta teoria da relação fiduciária não foi acolhida pela jurisprudência inglesa. Em capítulo anterior já fizemos referência a impropriedade da inserção dos contratos, em que há contraposição de interesses, na classe das relações fiduciárias.

${ }^{713}$ Embora reconheçamos que comumente as relações de agência sejam tratadas com mais abrangência. V. nota referente à interpretação de Richard Ippolito em Economics for Lawyers.
} 
Só se cogita do dever de informar em relação a fatos que o declarante conhece - ou deveria conhecer ${ }^{714}$. Portanto, as informações devem ser conhecidas do segurado ou, pelo menos acessíveis a ele, mediante ordinária diligência. Caso contrário, não se caracterizaria nem a omissão e nem a inexatidão.

Fabre-Magnan também sustenta que a ignorância do agente em relação ao fato omitido ou incorreto deve ser legítima, ou seja, a parte deve $s^{\prime}$ informer pour informer ${ }^{, 715}$, significando que não se pode admitir como justificativa a ignorância culposa. Mas também não se pode punir a ignorância legítima, desconsiderando os limites de tal dever, seja pela efetiva impossibilidade de acesso à informação, ou pelo custo de sua obtenção ${ }^{716}$.

Portanto, embora o dever valha para ambas as partes, que devem se informar para informar $^{717}$, só se deve exigir o dever de informar daquele que tem mais facilidade de obtêla e que pode evitar a desinformação ao custo mais baixo (cheapest cost avoider). Será, pois, escusável a ignorância, quando a parte desinformada tem acesso mais difícil à informação do que a outra. No caso do seguro, as informações exigidas do segurador concernem à sua maior capacidade técnica e à predisposição das cláusulas, com as restrições já comentadas. E, do segurado se exigem informações sobre o risco incidente sobre seu próprio interesse, que ele presumivelmente conhece ou deve conhecer melhor do que ninguém.

Mas a jurisprudência muitas vezes desconsidera a doutrina do cheapest cost avoider, impondo ao credor da informação os ônus de obtê-la, como se ignorasse os custos

\footnotetext{
${ }^{714}$ A lei italiana também invoca a boa fé como padrão de conduta pré-contratual (art. 1337). Mas a doutrina evita a flexibilização exagerada do modelo, pois infere automaticamente do padrão o dever de informar, independentemente da intenção, pois exige seu cumprimento sempre que "a parte conhece (ou deveria conhecer) dados relevantes para a valoração do contrato do ponto de vista da contraparte, e sabe (ou deveria saber) que esta os desconhece, tem o dever de informá-los". ROPPO, Vincenzo. Il contratto, cit., p. 177. Esta interpretação doutrinária pode ter sido influenciada pelo disposto no art. 1338: La parte che, conoscendo o dovendo conoscere l'esistenza di una causa di invalidità del contratto , non ne ha dato notizia all'altra parte è tenuta a risarcire il danno da questa risentito per avere confidato, senza sua colpa, nella validità del contratto. Ademais, considerando-se que informar pressupõe revelar a verdade, Roppo ressalta que agrava a ocultação se esta resulta de pergunta ou requisição de informação da contraparte. Id. Ibid., p. 178. Além do mais, admite a quebra do dever de boa-fé por culpa, como já referido em capítulo anterior. Esta concepção mais exigente do dever de informar muito contribui para a segurança das relações entre os agentes e, consequentemente, para o desenvolvimento da atividade econômica.

${ }^{715}$ FABRE-MAGNAN, Muriel. op. cit., p. 105.

${ }^{716}$ Rubén Stiglitz trata desses limites, classificando-os em objetivos e subjetivos, sem, contudo, considerar os custos da aquisição da informação, que são decisivos em relação à distribuição do dever de informar nos contratos. STIGLITZ, Rubén. La obligatión precontractual y contractual de información: el deber de conselho. Revista de Direito do Consumidor, São Paulo, n. 22, abr./jun. 1997.

${ }^{717}$ Patrice JOURDAIN afirma que o dever de informar é limitado pelo dever de se informar, na medida do possível. Acrescente-se, porém, que esse critério também deve ser examinado do prisma econômico, porque os custos da obtenção da informação também lhe restringem o acesso. "Le devoir de se renseigner" (JOURDAIN, Patrice. Contribution à l'étude de l'obligation de renseignement. Paris: Dalloz, 1983. p. 139).
} 
dessa aquisição, ou entendesse correto revertê-los àquele que tem mais dificuldade de adquiri-la, prestigiando a omissão ou inexatidão violadora da lei. Isto ainda ocorre nos casos de omissão e de falsidade de declaração concernente a doença preexistente, graves falhas informacionais indevidamente relevadas, sob o argumento de que à seguradora incumbiria fazer exame prévio nos proponentes ${ }^{718}$.

Evidentemente, nos casos em que não se tenha comprovado o conhecimento do segurado em relação à doença que o acomete, não se cogita de omissão ou inexatidão, porque estas pressupõem conhecimento da informação ou possibilidade de acesso a ela. E, neste caso, não se poderia exigir que o segurado devesse conhecer dados clínicos ou

${ }^{718}$ STJ REsp 777.974/MG, $3^{a}$ T.,Rel. Ministro Castro Filho, j. 09/05/2006, DJU 12/03/2007 p. 228. Ementa:
"Seguro de vida. Doença preexistente. Exames prévios. Ausência. Inoponibilidade. Conforme entendimento
pacificado desta Corte, a seguradora, ao receber o pagamento do prêmio e concretizar o seguro, sem exigir
exames prévios, responde pelo risco assumido, não podendo esquivar-se do pagamento da indenização, sob
a alegação de doença preexistente, salvo se comprove a deliberada má-fé do segurado. Recurso provido"
STJ Resp 234219/SP, 4a Turma, Rel. Min. Ruy Rosado de Aguiar, j. 15.05.2001 e Resp 300215/MG, 4a
Turma, Rel. Min. Aldir Passarinho Júnior, j.29.05.2001: "Seguro-saúde - Doença preexistente - AIDS.
Omissa a seguradora tocante à sua obrigação de efetuar exame de admissão do segurado, cabe-lhe
responder pela integralidade das despesas médico-hospitalares havidas com a internação do paciente, sendo
inoperante a cláusula restritiva inserta no contrato de seguro-saúde. Recurso conhecido em parte e
parcialmente provido." E esta decisão, a par da interpretação favorável do art. 47, acrescenta a abusividade
da cláusula limitativa, sem exame prévio. STJ Ag. Reg. no AI n ${ }^{\circ}$ 311.830 SP - Rel. Min. Castro Filho - J. 26.02.2002 - DJ 01.04.2002. Plano de Saúde - Seguro - Consumidor - Contrato de adesão - Cobertura dos riscos assumidos - Cláusula excluindo moléstia preexistente - Recebimento de contribuição sem submeter o associado a exame - Alegação de omissão ou má-fé do segurado - Impossibilidade - CDC, artigo 51, IV, $\S 1^{\circ}$, II. A empresa que explora plano de seguro-saúde e recebe contribuições de associado sem submetê-lo a exame, não pode escusar-se ao pagamento da sua contraprestação, alegando omissão ou má-fé nas informações do segurado. Plano de Saúde - Seguro - Contrato de adesão - Interpretação em favor do consumidor - CDC, artigo 47. Contratos de seguro médico, porque de adesão, devem ser interpretados em favor do consumidor.

STJ, EDcl - Ag 1251211/ES, 4ª Turma, Rel. Min. João Otávio de Noronha, DJe 02/03/2011: "Processo Civil. Embargos de Declaração. Agravo de instrumento. Fungibilidade recursal. Seguro. Doença preexistente. Violação do art. 535 do CPC. Não ocorrência. Má-fé. Não configuração. Reexame de provas. Súmula n. 7/ STJ. Recurso manifestamente improcedente. Multa. Art. 557, § 2 ${ }^{\circ}$, do CPC. (...)

3. A alegação de doença preexistente à contratação de seguro não justifica a recusa de cobertura de indenização securitária se a seguradora não houver submetido o segurado a prévio exame de saúde e não comprovar sua má-fé.

4. Constatada pelo Tribunal de origem a ausência de má-fé do segurado quando da assinatura do contrato de seguro, não cabe ao Superior Tribunal de Justiça, em sede de recurso especial, revisar as premissas fáticas que nortearam seu convencimento (Súmula n. 7/STJ).

(...) 6. Embargos de declaração recebidos como agravo regimental, a que se nega provimento."

STJ. REsp 402457/RO, 4. Turma - Min. Barros Monteiro, DJ 05/05/2003: " Seguro de Vida. Óbito. Alegação de Doença Preexistente. Ausência de Exame Prévio.

1. Em sede de recurso especial não se reexamina matéria probatória (Súmula n ${ }^{\circ}$ 7-STJ).

2. Não pode a seguradora eximir-se do dever de indenizar, alegando omissão de informações por parte do associado, se dele não exigiu exames clínicos prévios. Precedentes do STJ. Recurso especial não conhecido."

TJSP - Ap. c/ Rev. 665.730-00/7 - 11a Câm. - Rel. Juiz Egidio Giacoia - j. 19.4.2004: "Seguro de Vida e/ou Acidentes Pessoais - Indenização - Exame Médico - Dispensa - Risco - Ônus da Seguradora Reconhecimento - Cabimento. "Ao dispensar o exame médico prévio a seguradora assume automaticamente o risco, respondendo integralmente pela indenização. A ausência de prova de que o segurado conhecia a existência e extensão da moléstia incapacitante, cujo ônus era da seguradora, autoriza o reconhecimento da presunção de boa-fé a justificar o direito ao seguro contratado". 
médicos até então não revelados. Cuida-se aqui, portanto, somente da hipótese em que tenha sido comprovado o efetivo conhecimento do segurado de fatos relevantes a respeito de seu estado de saúde em data anterior à contratação ${ }^{719}$.

Pela lógica do contexto, a providência exigida incluiria exames clínicos, laboratoriais, e diagnósticos por imagem, todos muito dispendiosos e destinados a detectar doenças que o segurado já sabia que o acometiam antes da contratação, mas optou por omitir. Isto obviamente significa desperdício de recursos com a busca de informações que uma das partes (o segurado) poderia ter facilmente evitado, se tivesse cumprido o dever de informar, que, reitere-se, pressupõe revelar a verdade. Mas decisões judiciais que desconhecem a regra elementar do cheapest cost avoider, e prestigiam o descumprimento do dever de informar e a violação de um padrão, mínimo que seja, de boa-fé, criam incentivos para futuras condutas oportunistas, ensinando que o oportunismo compensa. Esta lição servirá para outros contratantes cogitarem de extrair do contrato ganhos indevidos em detrimento da contraparte, e, no caso do seguro, também em prejuízo da mutualidade, porque sabem, de antemão, que afinal não arcarão com as consequências de suas omissões e inverdades. E o mais curioso é que o fundamento dessa orientação jurisprudencial é a equidade, que certamente não se imaginava tão injusta.

Essa distribuição aparentemente gratuita de direitos gera externalidades a terceiros estranhos à relação processual, pois o fundo mútuo arcará com os custos dos tais exames prévios, que também tenderão a elevar o preço de futuros contratos, no segmento afetado. Isso representa redução no bem-estar social. Portanto, também não deve ser interpretada como uma suposta função social do contrato de seguro.

Embora a atividade jurisdicional implique a apreciação individual dos casos, deve considerar a natureza multitudinária do contrato de seguro e atentar à necessidade de manutenção de seu equilíbrio econômico, para que a solução de litígios entre segurado e seguradora não gere externalidades negativas para toda a coletividade.

O Tribunal de Justiça de São Paulo tem revertido a tendência protecionista, denotando equilíbrio na apreciação dos contratos de seguro ${ }^{720}$.

\footnotetext{
${ }^{719}$ Como é o caso dos processos arrolados na nota anterior, cujos acórdãos foram todos analisados antes de serem ali incluídos, verificando-se do seu inteiro teor, que havia sido comprovado o conhecimento da doença previamente à contratação.

${ }^{720}$ TJSP. Ap. N $^{\circ}$ 1262973-0/4 - Rel. Des. Celso Pimentel. j. 28/07/09: A omissão da segurada sobre moléstia de que padecia, de que tinha conhecimento e que lhe causou a morte caracteriza má-fé contratual e acarreta a perda do direito dos beneficiários à indenização, sem infringência a qualquer preceito do Código de Defesa do Consumidor.
} 
TJSP. Seção Dir. Priv., 35a Câmara, Apel. n 745717-0/7, Rel. Des. Artur Marques: "Seguro de Vida em Grupo - Indenização -Pretensão Julgada Improcedente - Dever de Lealdade e Boa-Fé -Doença Pré-Existente Aids - Sentença Mantida - Recurso Improvido. "O contrato de seguro é fundamentalmente bonae fidei, e em particular devendo dizer-se o de seguro de vida uberrima fidei, pois o segurador ao contratá-lo descansava quase que exclusivamente na lealdade, sinceridade e veracidade das declarações do segurado. "Na modalidade de seguro em grupo é frequiente a dispensa de exame médico, sendo aceita a proposta, tão somente a prestação de informações à Seguradora sobre o real estado de saúde do proponente";

TJSP. Ap. s/ Rev. 567.470-00/3 - 9a Câm. - Rel. Eros Piceli - j. 26.1.2000: "Seguro de Vida - Apólice em Grupo - Indenização - Exame Médico Prévio - Ausência - Irrelevância - Informação do Segurado que o substitui - Omissão configurada - Descabimento. "Não é condição para o contrato de seguro de vida em grupo o exame médico prévio".

TJ/SP. Apel. 9219974-71.2009.8.26.0000, $31^{\text {a }}$ Câm. de Dir. Priv, Rel. Antonio Rigolin, DJ 22/11/2011: Seguro de vida. Execução. Falsa afirmação do segurado quando do preenchimento da proposta. Reflexos na formulação das bases do contrato. Contratação nula. Procedência dos embargos reconhecida. Recurso provido. O contrato de seguro assenta-se essencialmente na boa-fé das partes, de modo que a falsa declaração ou omissão de fatos relevantes implica nulidade (artigos 765 e 766 do Código Civil). Faltando o segurado com a verdade, ao responder negativamente ao questionário sobre as suas condições de saúde, fazendo falsa afirmação, violou o preceito legal que lhe impõe a lealdade.

TJ/SP. Apel. 0010929-41.2010.8.26.0132, $31^{\mathrm{a}}$ Câm. de Dir. Priv, Rel. Adilson de Araujo, DJ 06/12/2011: Seguro de vida em grupo. Ação de indenização. Segurado que omite doença preexistente quando da contratação. Indenização indevida. Recurso provido. O Código Civil, mais precisamente nos art. 765 e 766, ordena aos contratantes a mais estrita boa-fé e veracidade, quando da confecção do contrato. Assim, se o segurado não faz declarações verdadeiras e completas, e omite certas informações que influenciariam na aceitação da proposta ou na taxa do prêmio, terá, como consequência, o perdimento do direito ao valor do seguro.

TJ/SP. Apel. 9075743-82.2008.8.26.0000, $28^{a}$ Câm. de Dir. Priv, Rel. Júlio Vidal, DJ 22/11/2011: Seguro de vida e acidentes pessoais. Cobrança. Doença preexistente. Omissão do segurado na declaração de estado de saúde contida na proposta de seguro. Havendo omissão por parte do segurado no preenchimento da proposta de seguro, não se observando a boa-fé prevista em lei, de rigor a improcedência do pleito, em face da perda do direito indenizatório (artigos 1443 e 1444 do CC/1916, correspondente aos artigos 765 e 766 do CC/2002). Sentença reformada. Recurso provido

TJSP. Apel. 0003225-93.2009.8.26.0137, Rel. Kioitsi Chicuta, 32 ${ }^{\mathrm{a}}$ Câmara de Direito Privado, DJ 08/09/2011: "Seguro. Veículo automotor. Recusa da seguradora no pagamento da indenização sob argumento de omissão quanto à utilização do veículo por menor de 25 anos. Ação indenizatória julgada improcedente. Omissão do autor no perfil de cada usuário. Acidente ocorrido quando o veículo estava sendo usado pelo filho de 25 anos. Má-fé do segurado caracterizada. Recurso desprovido. Omitindo o segurado informação de que tinha filhos menores de 25 anos, e que poderiam fazer uso do veículo, impedindo a seguradora de avaliar o prêmio de acordo com o perfil apresentado, atua aquele de má-fé, desobrigando a seguradora ao pagamento de indenização em caso de acidente. Mesmo sendo representado pelo corretor e encaminhado tais informações, continua sendo o responsável pela veracidade do alegado."

TJSP. Apel. 992.06.018989-3, $30^{\text {a }}$ Câm. de Dir. Priv. Rel. Lino Machado, DJ. 11.08.2010: Seguro de vida em grupo - Cobrança - Doença preexistente - Morte do segurado - Má-fé. Não é devida a indenização por morte do segurado, quando comprovada má-fé em omitir informação acerca de doença grave preexistente, causadora da morte - Importante ressaltar que a vítima, em razão da profissão que exercia, estava, sem dúvida, consciente da gravidade que a sua insuficiência imunológica lhe apresentava para sua saúde - O importante para a solução da lide não é que a AIDS seja doença ou simples deficiência do organismo de defesa contra agentes causadores de desequilíbrio no funcionamento de órgãos vitais. O importante é que, seja ou não doença, o portador do vírus HIV vive sob o risco sempre iminente de cair gravemente enfermo e de morrer por falência geral de seu organismo (...)"

TJ/SP, Apel. 0138775-11.2008.8.26.0100, 33ª Câm. Dir. Priv, Rel. Walter Cesar Exner, DJ: 24/11/2011. "Seguro de vida e acidentes pessoais. Embargos à execução. Indenização relativa à morte de segurado. Omissão de informação relevante no momento de contratação do seguro. Prova suficiente de ciência inequívoca do segurado acerca do mal que gerou o sinistro. Doença preexistente. Má-fé caracterizada. Inteligência do artigo 766 do CC/02. Verba indevida. Embargos acolhidos. Recurso improvido."

TJ/SP, Apel. 0028507-43.2010.8.26.0576, $28^{a}$ Câm. Dir. Priv, Rel. Celso Pimentel, DJ: 24/11/2011: “A omissão da segurado sobre moléstia de que padecia, de que tinha conhecimento e que lhe causou a morte, caracteriza má-fé contratual e acarreta a perda do direito da beneficiária à indenização. Por isso, mantém-se o acolhimento dos embargos da seguradora."

TJ/SP, Apel. 0001037-77.2006.8.26.0414, $28^{\text {a }}$ Câm. Dir. Priv, Rel. Cesar Lacerda, DJ 26/07/2011: "Seguro de vida e acidentes pessoais. Indenização securitária. Cobrança. Doença pré-existente. Omissão do 


\section{Elemento subjetivo}

A presunção de conhecimento dos fatos $^{721}$ que dizem respeito a cada uma das partes é importante, porque inverte o ônus da prova, que incumbirá sempre àquele contra quem se erige a presunção. Com base na natural distribuição da informação entre as partes no contrato de seguro, constrói-se a presunção de que o segurado conhece ou deve conhecer seu próprio risco, e sabe que deve descrevê-lo fielmente ao segurador na formação do contrato, e, portanto, ele é que tem de provar por que não o fez. Essa prova dos motivos da omissão ou inexatidão concerne ao elemento subjetivo, e cabe ao segurado. Ao segurador só caberia comprovar a omissão ou incorreção da informação e a relevância dos fatos omitidos ou distorcidos em relação ao risco, se esta não emergir evidente das próprias circunstâncias fáticas.

Por isso, é atécnico, ineficiente e injusto exigir do segurador a prova da intenção da contraparte em relação à falha informacional ${ }^{722}$.

segurado. Cerceamento de defesa. Inocorrência. Não identificada a necessidade ou mesmo a utilidade da
produção das provas requeridas, não há que se falar em cerceamento de defesa. Age de má-fé o segurado
que, ao responder questionário sobre suas condições de saúde, omite ser portador de doença que
posteriormente provocou sua invalidez, embora tivesse conhecimento desse fato no momento da
contratação do seguro, ficando a seguradora exonerada da obrigação de pagamento da indenização prevista
na apólice. Recurso não provido." TJ/SP, Apel. 0011398-46.2006.8.26.0482, $7^{\text {a }}$ Câm. Dir. Priv, Rel. Cesar Lacerda, DJ 07/06/2011: "Seguro de vida e acidentes pessoais. Indenização securitária. Cobrança. Doença pré-existente. Omissão do segurado. Falecimento do segurado no curso da lide. Sucessão pelo espólio. Admissibilidade. Pretensão ao recebimento de indenização securitária por invalidez. Direito transmissível aos herdeiros. Age de má-fé o segurado que omite ser portador de diabetes ao responder questionário sobre suas condições de saúde, ficando a seguradora exonerada da obrigação de pagamento da indenização prevista na apólice, notadamente se a invalidez do contratante foi motivada por complicação ocular (retinopatia diabética) decorrente daquela moléstia. Recurso não provido."

TJ/SP, Apel. 9156393-53.2007.8.26.0000, $7^{\text {a }}$ Câm. Dir. Priv, Rel. Andrade Neto, DJ 08/06/2011: "Seguro de vida e acidentes pessoais em grupo - Morte do segurado após complicações no pós-operatório de transplante de fígado - Omissão de doença crônica (cirrose hepática) pré-existente à contratação do seguro - Conhecimento do segurado - Má-fé configurada - Indenização indevida - sentença mantida. Apelação desprovida.”

TJ/SP, Apel. 9130754-67.2006.8. 26.0000, 29a Câm. Dir. Priv, Rel. Ferraz Felisardo, DJ 07/07/2010: "Seguro de vida e acidentes pessoais - Cobrança - Morte do segurado - Informação falsa sobre o estado de saúde - Omissão de informação relevante no pedido de aumento do capital segurado - Prova suficiente de ciência inequívoca do segurado acerca do mal que gerou o sinistro - Doença preexistente - Má-fé caracterizada - Inteligência do artigo 766 do código civil - Recurso não provido.”

${ }^{721}$ STIGLITZ, Rubén S. Derecho de seguros, cit., p. 390.

${ }^{722}$ TJ/SP, Apel. 0001080-07.2005.8.26.0072, 29a Câm. Dir. Priv. Rel. Pereira Calças, DJ 14/12/2011: Ementa:.Apelação. Ação de cobrança de indenização. Seguro de vida e acidentes pessoais. Alegação de doença pré-existente. Prova da má-fé da segurada. Inexistência. Aplicação do CDC. Sentença mantida por seus próprios fundamentos, ora reproduzidos (art. 252 do RITJSP). Precedentes do STJ e STF. Apelo a que se nega provimento.

(...) Nesse contexto, o médico Durval Renato Wohnrath, do quadro do Hospital de Câncer de Barretos Fundação Pio XII, esclareceu que consultou a segurada Vera Lucia pela primeira vez em 20 de fevereiro de 2002, tendo constatado ser ela portadora de 'câncer de mama avançado'. Acrescentou que a paciente foi encaminhada ao hospital e 'chegou intacta', isto é, sem ter sido anteriormente submetida à cirurgia ou a qualquer outro tipo de tratamento. Faleceu em decorrência da evolução natural da doença, após ter sido 
operada em maio de 2002, com reaparecimento da doença em janeiro de 2003, sobrevindo o seu falecimento em 01 de outubro de 2004 (fls. 154) (...)

Como se vê, a despeito da proximidade de datas entre a constatação da doença e a contratação do seguro, não há provas seguras de que a segurada já tinha conhecimento do mal que a acometia antes de assinar o cartãoproposta. Os documentos de fls. 76/77, embora produzidos quatro dias antes da assinatura do cartão-proposta, não são suficientes para demonstrar que a segurada, por sua simples leitura, teria consciência da gravidade de seu quadro de saúde. Sendo assim, em caso de dúvida, pela sistemática da legislação de proteção ao consumidor, interpreta-se a norma favoravelmente a este, razão pela qual deve ser mantida a procedência da ação."

- TJ/SP. Apel. 9066025-66.2005.8.26.0000. 5ª Câm. Dir. Priv., Rel. A.C. Mathias Coltro, DJ 19/10/2011:

Seguro habitacional - Financiamento de imóvel - Pretendida quitação do mútuo, em razão do óbito do segurado - Negativa de cobertura, sob a alegação de que o segurado, falecido marido da autora, era portador de graves doenças, antes da contratação do seguro, tendo omitido tais informações em sua declaração de saúde - Perícia grafotécnica que comprovou que a assinatura lançada na declaração de saúde não partiu do punho do falecido, que, um ano antes, havia sofrido derrame cerebral, passando a ter sua assinatura totalmente modificada - Pagamento dos prêmios - Ausência de prova de má- fé dos segurados - Doença do falecido que era perceptível e foi omitida pelo corretor quando da assinatura da apólice - Cobertura securitária devida - adoção dos fundamentos da sentença, em razão do permissivo do artigo 252 do Regimento interno desta egrégia corte - Sentença mantida - Recursos desprovidos.

- TJ/SP. Apel. 0015582-88.2008.8.26.0348, 29 ${ }^{\mathrm{a}}$ Câm. Dir. Priv, Rel. Reinaldo Caldas, DJ 30/11/2011:

"Seguro Ação de cobrança- Furto de automóvel- Negativa de cobertura ao fundamento de que o segurado prestou informações falsas no questionário, as quais limitaram o risco e geraram prêmio inferior ao que seria devido, implicando a perda do direito à indenização securitária, nos termos dos arts. 765 e 766 do CC/02 Relação de consumo Inversão do ônus da prova (art. $6^{\circ}$, VIII, do CDC) - Falta de prova de má-fé do segurado, ou mesmo de que ele tenha prestado informações falsas, podendo a discrepância das informações ter sido gerada por erro da corretora. Recusa indevida ao pagamento da indenização - Responsabilidade solidária da seguradora, que aceitou questionário de perfil com falhas evidentes e não assinado pelo proponente Sinistro, ademais, que independe de perfil do condutor Prova do agravamento do risco, de que depende a negativa de pagamento, que cabia à seguradora e não foi produzida Aplicação sistemática dos arts. 766, 768 e 769 do Código Civil. Sentença reformada. Recurso provido, com observação".

- TJ/RS. Apel. 70045755675, $5^{\text {a }}$ Câm. Rel. Romeu Marques Ribeiro Filho, J 14/12/2011: Apelação Cível. Seguro de vida. Relação de consumo. Aplicação do cdc. Negativa de cobertura pela seguradora. Alegação de doença preexistente. Má-fé do segurado quando do preenchimento da proposta não comprovada. Precedentes do STJ. Ausência de exames prévios. Pagamento da indenização securitária devido. Trata-se de relação de consumo, devendo ser aplicadas as normas e regras do CDC. Em se tratando de suposta doença preexistente, cabia à seguradora, quando da contratação do seguro, tomar as cautelas devidas, submetendo o segurado a exames prévios, o que não ocorreu. Além disso, ao aceitar as informações prestadas pelo segurado, sem contestá-las, firmando o contrato e recebendo os respectivos prêmios, despropositada a negativa de pagamento da indenização securitária. Afinal, é ônus da seguradora comprovar a alegação de má-fé do segurado quando do preenchimento da proposta de seguro. Hipótese em que não restou inequivocamente demonstrada a má-fé do segurado. Apelação desprovida.

- TJ/SP. Apel. 0030138-77.2008.8.26.0451, 33ª Câm. Dir. Priv, Rel. Sá Duarte, DJ 02/05/2011:

"Do que é dado extrair dos autos, o segurado não tinha, em absoluto, certeza de morte próxima, a despeito dos problemas de saúde que enfrentava, tanto que depois da contratação viveu ainda por aproximadamente quinze anos, tendo exercido o seu trabalho até as vésperas de sua morte, fato inclusive que restou incontroverso nos autos.

A cirurgia a que se submeteu e as consultas que havia feito até então ao médico, não indicavam, do que é permitido extrair dos autos, probabilidade de morte, depreendendo-se que foram consultas rotineiras motivadas pela miocardiopatia isquêmica que o acometia, decorrente de lesões nas artérias coronarias, conforme se infere da vasta documentação médica acostada aos autos e, especialmente, do depoimento prestado pelo médico responsável pelo tratamento do segurado (fls. 231/232). É preciso ter em conta que a doença arterial coronariana está relacionada ao sedentarismo e à adoção de hábitos nocivos à saúde e que, exatamente por isso, atualmente acomete boa parte da população brasileira.

Estudo acadêmico realizado no ano de 2001 na Faculdade de Medicina da Universidade de São Paulo aponta que no Brasil são cerca de 300 a 350 mil infartos anuais decorrentes destes distúrbios (CARVALHO, T.C. Reabilitação cardíaca em portadores de cardiopatia isquemica com obstruções coronárias passíveis de tratamento intervencionista. Tese (Doutorado) - Faculdade de Medicina, Universidade de São Paulo, 2001).

De rigor ponderar, portanto, que o mal que acometia o segurado não pode ser considerado daquele que autoriza prognóstico ruim. Muitas pessoas padecem dessa doença, sobretudo, como dito, em razão do 
Os regimes jurídicos mais exigentes em relação ao dever de informar no contrato de seguro, como o Reino Unido e Portugal, consideram irrelevante o elemento subjetivo, sob o argumento de que a fraude estaria implícita na ocultação e, com mais razão, na distorção dos dados concernentes ao risco.

A percepção da relevância da informação pelo segurado também opera como indício de fraude, pois, se era possível saber da importância da informação em relação ao risco, o que se infere das circunstâncias pessoais do segurado e do contexto fático subjacente ao contrato, não se deveria afastar o dolo.

Mas a maioria dos países de Civil Law, como veremos, distingue a omissão ou inexatidão dolosa da culposa, estabelecendo consequências diferentes em relação a cada hipótese.

A opção legislativa mais severa, que dispensa o elemento subjetivo, favorece o segurador e o fundo mútuo, porque limita a discussão judicial a dados objetivos, relativos ao conhecimento dos fatos pelo devedor ou pelo credor da informação, o custo da obtenção desta pelas partes, e a relevância dos dados omitidos ou distorcidos em relação ao risco.

A distinção legal entre culpa e dolo serve para diferenciar entre as infrações mais e as menos graves, pretensamente por questões de equidade, embora o resultado das infrações em relação ao segurador e à mutualidade seja o mesmo. Mas, ao fazê-lo, a lei cria obstáculo praticamente intransponível à seguradora, representado pela dificuldade da prova do elemento subjetivo da contraparte. Se, prevendo o equívoco da interpretação de que a prova da intenção seria ônus da seguradora, a lei tivesse estabelecido expressamente que, diante da presunção de conhecimento dos fatos pelo segurado, a este caberia provar por que não os informou, não teria criado uma iniquidade para reparar outra.

Mas mesmo distinguindo entre dolo e culpa, a maioria dos sistemas jurídicos estrangeiros $^{723}$ contrabalança eficientemente esse benefício da dúvida concedido ao segurado, com as sanções cominadas aos casos de omissão e inexatidão culposa. Os referidos regimes jurídicos punem o dolo com a perda da garantia e do prêmio. E

\footnotetext{
sedentarismo e de hábitos nocivos tão comuns nos tempos atuais e, nem por isso, consideram-se doentes, incapazes de uma vida normal, a ponto de, imbuídos de má-fé, responderem negativamente a questões da largueza interpretativa que as formuladas no questionário contido na proposta proporcionam.

Somente na hipótese em que caracterizada estivesse a má-fé do segurado é que a seguradora poderia recusar validamente a cobertura contratada, em conta o entendimento de que a boa-fé se presume e a má-fé deve ser provada. O estudo dos autos, contudo, demonstra que não é situação com que se defronta neste julgamento."

${ }^{723}$ Com exceção da Alemanha, como se verá no tópico pertinente.
} 
sancionam a culpa, com resolução do contrato ou alteração da proporção risco-prêmio mediante consentimento do segurado, se o sinistro ainda não tiver ocorrido à data da descoberta da omissão ou inexatidão; e, se o sinistro já tiver ocorrido (que é o mais provável), reduzem proporcionalmente a indenização. A redução proporcional da indenização após a ocorrência do sinistro é solução mais técnica, eficiente e justa do que a majoração do prêmio.

Se a omissão ou inexatidão estiver contida em resposta a inquirição do segurador, a presunção de fraude está in re ipsa. Como argumenta Mayaux, não se justifica o segurado fornecer resposta errada em questionário formulado pela seguradora, sobre fato que ele não poderia ter esquecido, pois a própria pergunta o teria lembrado ${ }^{724}$. A ciência da relevância da informação não revelada ou distorcida é indício da intenção do segurado em relação à quebra do dever de informar.

\section{Relevância da informação omitida ou distorcida. Critérios de aferição}

Ao longo do tempo houve alterações em relação aos critérios de aferição do cumprimento do padrão de máxima boa-fé e do dever de informar.

Inicialmente não se exigia prova de que a omissão ou inexatidão teria induzido o segurador em erro, pois a indução era considerada implícita. Então se adotou o denominado teste de materialidade para detectar a relevância da informação omitida ou distorcida, com base no padrão do segurador prudente, inferindo-se que fatos seriam, em tese, aptos a influenciar a decisão de um profissional zeloso e diligente em relação à

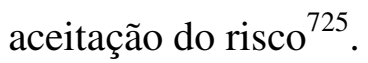

Constatado que nem sempre seria razoável presumir a percepção do segurado quanto à relevância das informações para o segurador, e a indução deste a contratar em bases equivocadas, buscaram-se outras fórmulas de demonstrá-lo.

Recorreu-se, então, a outro critério segundo o qual ao segurador incumbiria provar a relevância da omissão ou distorção, sem a qual ele não teria celebrado o contrato ou o

\footnotetext{
${ }^{724}$ MAYAUX, Luc. L’ignorance du risque. Revue Générale du Droit des Assurances, 1999. p. 735.

${ }^{725}$ TARR, Julie-Anne. Information disclosure: consumers, insurers and insurance contracting process. Lincoln: Authors Choice Press, 2001. p. 61-62.
} 
teria feito em bases diferentes ${ }^{726}$. Este critério da prova da indução do segurador pelas informações do segurado passou a ser combinado com o teste do segurador prudente.

Atualmente, com o desenvolvimento de questionários, a seguradora consegue obter do segurado mais informações, e, cria presunção de relevância de tudo o que consta do questionário. Em relação a omissões ou distorções de fatos que não tenham sido objeto de inquirição, deverá a seguradora comprovar a relevância, a menos que esta se evidencie a partir das próprias circunstâncias.

Algumas legislações, como a francesa, adotam o princípio do questionário fechado, que, segundo parte da doutrina, limitaria a relevância da informação exclusivamente à matéria objeto das questões formuladas por escrito pela seguradora ${ }^{727}$. Moitinho de Almeida diverge desta presunção segundo a qual só são relevantes em relação ao risco as informações objeto do questionário, argumentando que o formulário de perguntas não deveria redundar em prejuízo para o segurador, porque representa um benefício por ele prestado ao proponente ${ }^{728}$. Embora ele tenha razão quanto à assertiva, não parece acertada sua justificativa. Não se trata de benefício, nem se pode dizer que tenha sido dedicado à contraparte, embora possa eventualmente auxiliá-la a se lembrar dos dados referentes ao risco. É, na verdade, um procedimento de escrutínio, destinado a extrair informações do proponente, no interesse do próprio segurador e da mutualidade.

É razoável que o questionário induza presunção de relevância, mas, devido à variedade de dados aos quais só o proponente tem acesso e que seriam relevantes em relação ao risco, não se deve excluir a relevância de eventual informação que, nem mesmo a expertise do segurador poderia antever.

A prática de extração de informações da contraparte (screening), como já observado, demanda investimento de recursos e representa custos de transação. A compreensão de que esses processos de screening são instrumentos de identificação de riscos, com o objetivo de viabilizar sua correta mensuração, que é essencial à atividade securitária, induz à conclusão de que não se pode desconsiderar as omissões ou distorções detectadas nas respostas ao questionário da seguradora, sob pena de anular sua função.

\footnotetext{
${ }^{726} \mathrm{O}$ caso paradigmático em relação a esta questão é o Pan Atlantic Insurance Co. v. Pine Top Insurance Co. (1994) 3 W.L.R. 677, p. 711-712.

${ }^{727}$ COUILBAULT, François; ELIASHBERG, Constant; LATRASSE, Michel. op. cit., p. 92-93.

${ }^{728}$ ALMEIDA, José Carlos Moitinho de. O contrato de seguro no direito português e comparado. Lisboa: Sá da Costa Ed., 1971. p. 74.
} 
As respostas omissas ou distorcidas ao questionário devem ser objetivamente consideradas para efeito da sanção legal, e punidas como violação da boa-fé, que é um padrão objetivo de conduta.

Mas, ironicamente, para caracterizar quebra do dever de boa-fé, impõe-se à seguradora o ônus de provar a má-fé do segurado, quando a intenção deste emana da própria ocultação ou distorção da verdade nas respostas ao questionário, anulando a função deste importante instrumento de escrutínio destinado a identificar riscos, e a mensurá-los, como única forma de viabilizar a atividade securitária.

\section{Análise do Direito Comparado}

\section{França}

O regime jurídico francês prevê consequências diversas para o descumprimento do dever de informar. Subordina a anulação do contrato e perda da garantia à má-fé do segurado, concedendo ao segurador direito a todos os prêmios vencidos (art. 113-8 ${ }^{729}$ ). Se as falhas na declaração de risco não forem intencionais, não caberá anulação do contrato. Se o segurador tomar conhecimento da omissão ou inexatidão antes do sinistro, poderá optar entre manter o contrato, majorando o prêmio, dependendo de aceitação da contraparte, ou a resolvê-lo, após notificação ao segurado e restituição do prêmio pago proporcionalmente ao período em que o contrato não mais vigorará. Se o segurador tomar conhecimento da falha de informação do segurado somente depois da materialização do risco, a indenização será reduzida na proporção entre o prêmio efetivamente pago e o prêmio que deveria ter sido pago se tivesse sido declarado corretamente o risco (art. 113-9 ${ }^{730}$ ).

\footnotetext{
${ }^{729}$ Article L113-8 Code des Assurances alt. pela L. 81 de 07.01.81 (Omissões ou inexatidões intencionais) Indépendamment des causes ordinaires de nullité, et sous réserve des dispositions de l'article L. 132-26, le contrat d'assurance est nul en cas de réticence ou de fausse déclaration intentionnelle de la part de l'assuré, quand cette réticence ou cette fausse déclaration change l'objet du risque ou en diminue l'opinion pour l'assureur, alors même que le risque omis ou dénaturé par l'assuré a été sans influence sur le sinistre. Les primes payées demeurent alors acquises à l'assureur, qui a droit au paiement de toutes les primes échues à titre de dommages et intérêts.

${ }^{730}$ Article L113-9 Code des Assurances. (Omissões ou inexatidões sem má-fé).

L'omission ou la déclaration inexacte de la part de l'assuré dont la mauvaise foi n'est pas établie n'entraîne pas la nullité de l'assurance.

Si elle est constatée avant tout sinistre, l'assureur a le droit soit de maintenir le contrat, moyennant une augmentation de prime acceptée par l'assuré, soit de résilier le contrat dix jours après notification adressée à l'assuré par lettre recommandée, en restituant la portion de la prime payée pour le temps où l'assurance ne court plus.
} 


\section{Itália}

A lei italiana prevê a anulação do contrato por ocultação ou distorção de informações decorrente de dolo ou culpa grave, cumulada com o direito de retenção do prêmio pelo segurador (Art. $1892 \mathrm{CC}^{731}$ ). Não tendo havido dolo nem culpa grave, o segurador terá direito a resolver o contrato no prazo de três meses contados do seu conhecimento da omissão ou inexatidão, se for antes da ocorrência do sinistro. Se for depois, a indenização será reduzida na proporção entre o prêmio efetivamente pago e o prêmio que deveria ter sido pago se tivesse sido declarado corretamente o risco (Art. $1893 \mathrm{CC}^{732}$ ).

\section{Bélgica}

A legislação belga é semelhante à da França. Prevê consequências diversas para o descumprimento do dever de informar dependendo do elemento subjetivo. Se as omissões ou inexatidões forem intencionais, o contrato poderá ser anulado, sem prejuízo do pagamento dos prêmios vencidos até o momento em que o segurador teve ciência da omissão ou inexatidão, devendo-lhe ser restituída a indenização que eventualmente tenha sido paga. Falhas de informação não intencionais do segurado não acarretarão a invalidade contratual, mas autorizam o segurador a propor alteração do contrato, cuja forma não é

Dans le cas où la constatation n'a lieu qu'après un sinistre, l'indemnité est réduite en proportion du taux des primes payées par rapport au taux des primes qui auraient été dues, si les risques avaient été complètement et exactement déclarés.

${ }^{731}$ Art. 1892 CC. Dichiarazioni inesatte e reticenze con dolo o colpa grave.

Le dichiarazioni inesatte e le reticenze del contraente, relative a circostanze tali che l'assicuratore non avrebbe dato il suo consenso o non lo avrebbe dato alle medesime condizioni se avesse conosciuto il vero stato delle cose, sono causa di annullamento del contratto quando il contraente ha agito con dolo o con colpa grave.

L'assicuratore decade dal diritto d'impugnare il contratto se, entro tre mesi dal giorno in cui ha conosciuto l'inesattezza della dichiarazione o la reticenza, non dichiara al contraente di volere esercitare l'impugnazione.

L'assicuratore ha diritto ai premi relativi al periodo di assicurazione in corso al momento in cui ha domandato l'annullamento e, in ogni caso, al premio convenuto per il primo anno. Se il sinistro si verifica prima che sia decorso il termine indicato dal comma precedente, egli non è tenuto a pagare la somma assicurata.

Se l'assicurazione riguarda più persone o più cose, il contratto è valido per quelle persone o per quelle cose alle quali non si riferisce la dichiarazione inesatta o la reticenza.

${ }^{732}$ Art. 1893 CC. Dichiarazioni inesatte e reticenze senza dolo o colpa grave.

Se il contraente ha agito senza dolo o colpa grave, le dichiarazioni inesatte e le reticenze non sono causa di annullamento del contratto, ma l'assicuratore può recedere dal contratto stesso, mediante dichiarazione da farsi all'assicurato nei tre mesi dal giorno in cui ha conosciuto l'inesattezza della dichiarazione o la reticenza.

Se il sinistro si verifica prima che l'inesattezza della dichiarazione o la reticenza sia conosciuta dall'assicuratore, o prima che questi abbia dichiarato di recedere dal contratto, la somma dovuta è ridotta in proporzione della differenza tra il premio convenuto e quello che sarebbe stato applicato se si fosse conosciuto il vero stato delle cose. 
legalmente prevista, podendo ser efetivada, por exemplo, mediante majoração do prêmio ou estabelecimento de franquia. Caso o segurado recuse a proposta de alteração ou deixe fluir in albis o prazo para aceitação, o segurador terá quinze dias para resolver o contrato. Se já ocorrido o sinistro quando o segurador tomar conhecimento da omissão ou inexatidão, e não se constatar culpa do segurado, a indenização é integralmente devida; em se verificando que houve negligência deste, a indenização será reduzida na proporção entre o prêmio efetivamente pago e o prêmio que deveria ter sido pago se tivesse sido declarado corretamente o risco ${ }^{733}$.

\footnotetext{
${ }^{733}$ Art. 5 - 25.6.1992. Obligation de déclaration.
}

Le preneur d'assurance a l'obligation de déclarer exactement, lors de la conclusion du contrat, toutes les circonstances connues de lui et qu'il doit raisonnablement considérer comme constituant pour l'assureur des éléments d'appréciation du risque. Toutefois, il ne doit pas déclarer à l'assureur les circonstances déjà connues de celui-ci ou que celui-ci devrait raisonnablement connaître. Les données génétiques ne peuvent pas être communiquées.

S'il n'est point répondu à certaines questions écrites de l'assureur et si ce dernier a néanmoins conclu le contrat, il ne peut, hormis le cas de fraude, se prévaloir ultérieurement de cette omission.

Art. 6 - L. 25.6.1992. Omission ou inexactitude intentionnelles.

Lorsque l'omission ou l'inexactitude intentionnelles dans la déclaration induisent l'assureur en erreur sur les éléments d'appréciation du risque, le contrat d'assurance est nul.

Les primes échues jusqu'au moment où l'assureur a eu connaissance de l'omission ou de l'inexactitude intentionnelles lui sont dues.

Art. 7 - L. 25.6.1992. Omission ou inexactitude non intentionnelles.

$\S 1$. Lorsque l'omission ou l'inexactitude dans la déclaration ne sont pas intentionnelles, le contrat n'est pas nul.

L'assureur propose, dans le délai d'un mois à compter du jour où il a eu connaissance de l'omission ou de l'inexactitude, la modification du contrat avec effet au jour où il a eu connaissance de l'omission ou de l'inexactitude.

Si l'assureur apporte la preuve qu'il n'aurait en aucun cas assuré le risque, il peut résilier le contrat dans le même délai.

Si la proposition de modification du contrat est refusée par le preneur d'assurance ou si, au terme d'un délai d'un mois à compter de la réception de cette proposition, cette dernière n'est pas acceptée, l'assureur peut résilier le contrat dans les quinze jours.

L'assureur qui n'a pas résilié le contrat ni proposé sa modification dans les délais indiqués ci-dessus ne peut plus se prévaloir à l'avenir des faits qui lui sont connus.

§ 2. Si l'omission ou la déclaration inexacte ne peut être reprochée au preneur d'assurance et si un sinistre survient avant que la modification du contrat ou la résiliation ait pris effet, l'assureur doit fournir la prestation convenue.

§ 3. Si l'omission ou la déclaration inexacte peut être reprochée au preneur d'assurance et si un sinistre survient avant que la modification du contrat ou la résiliation ait pris effet, l'assureur n'est tenu de fournir une prestation que selon le rapport entre la prime payée et la prime que le preneur d'assurance aurait dû payer s'il avait régulièrement déclaré le risque.

Toutefois, si lors d'un sinistre, l'assureur apporte la preuve qu'il n'aurait en aucun cas assuré le risque dont la nature réelle est révélée par le sinistre, sa prestation est limitée au remboursement de la totalité des primes payées.

\$ 4. Si une circonstance inconnue des deux parties lors de la conclusion du contrat vient à être connue en cours d'exécution de celui-ci, il est fait application de l'article 25 ou de l'article 26 suivant que ladite circonstance constitue une diminution ou une aggravation du risque assuré. 


\section{Espanha}

A legislação espanhola de seguros prevê o direito do segurador à resolução do contrato mediante comunicação ao segurado até um mês depois do conhecimento da omissão ou inexatidão. Caso o segurador tome conhecimento da falha de informação depois da ocorrência do sinistro, a solução dependerá do elemento subjetivo do segurado: se constatado dolo ou culpa grave, este não terá direito à indenização; se não, a indenização será reduzida proporcionalmente à diferença entre o prêmio pago e o que seria devido, se não fosse a omissão ou inexatidão. Em qualquer das hipóteses, só em caso de dolo ou culpa grave do segurador, o segurado terá direito à devolução do prêmio vencido. (art. 10 da Lei 50 de $08.10 .1980^{734}$ ).

\section{Alemanha}

A legislação alemã também prevê anulação do contrato para a hipótese de dolo na omissão ou inexatidão das declarações de risco ( $\$ 22$ Versicherungsvertragsrechts ${ }^{735}$ ). No caso de culpa do segurado, caberá resolução do contrato, se o segurador tomar conhecimento das omissões ou inexatidões antes da ocorrência do sinistro. Ainda em caso de culpa do segurado nas falhas de informação conhecidas do segurador após o sinistro, este ficará obrigado a prestar a indenização, se a omissão ou inexatidão não tiver contribuído para a ocorrência do sinistro nem para o aumento do montante indenizatório ( $§$ 21 Versicherungsvertragsrechts ${ }^{736}$ ). A exigência do nexo causal entre o defeito das

\footnotetext{
${ }^{734}$ Artículo 10.

El tomador del seguro tiene el deber, antes de la conclusión del contrato, de declarar al asegurador, de acuerdo con el cuestionario que éste le someta, todas las circunstancias por él conocidas que puedan influir en la valoración del riesgo. Quedará exonerado de tal deber si el asegurador no le somete cuestionario o cuando, aun sometiéndoselo, se trate de circunstancias que puedan influir en la valoración del riesgo y que no estén comprendidas en él.

El asegurador podrá rescindir el contrato mediante declaración dirigida al tomador del seguro en el plazo de un mes, a contar del conocimiento de la reserva o inexactitud del tomador del seguro. Corresponderán al asegurador, salvo que concurra dolo o culpa grave por su parte, las primas relativas al período en curso en el momento que haga esta declaración.

Si el siniestro sobreviene antes de que el asegurador haga la declaración a la que se refiere el párrafo anterior, la prestación de éste se reducirá proporcionalmente a la diferencia entre la prima convenida y la que se hubiese aplicado de haberse conocido la verdadera entidad del riesgo. Si medió dolo o culpa grave del tomador del seguro quedará el asegurador liberado del pago de la prestación.

${ }^{735} § 22$ VVG. Fraudulent misrepresentation.

The right of the insurer to avoid the contract on account of fraudulent misrepresentation shall remain unaffected.

${ }^{736} \$ 21$ VVG. Exercising of the insurer's rights.

(1) The insurer must assert the rights afforded him in accordance with section 19 (2) to (4) in writing within one month. The period shall commence at such time as the insurer learns of the breach of the duty of disclosure on which the right he is asserting is founded. When exercising his rights, the insurer shall
} 
informações prestadas pelo segurado e a ocorrência ou a intensidade do sinistro é incompatível com o princípio da proporcionalidade entre risco e prêmio, que não guarda relação alguma com o sinistro $^{737}$.

\section{Portugal}

O regime português tão exigente quanto o britânico com relação às declarações de risco, que devem conter todas as circunstâncias que possam influenciar na decisão do segurador de aceitá-lo (art. 429 do Código Comercial $^{738}$ ). Prescinde do exame do elemento subjetivo para autorizar a anulação do contrato com fundamento em omissão ou inexatidões da declaração do risco. A dispensa dos pressupostos da relevância do erro exigidos pela legislação civil é criticada por Júlio Gomes ${ }^{739}$, sob o argumento de que até erros que causem diferenças marginais no cálculo do prêmio podem, em tese, invalidar o contrato. Basta que o erro tenha influído na avaliação do risco, e que o risco assumido não seja o efetivo. A lei não exclui a relevância das questões não constantes do questionário, exigindo que a prestação de informação pelo segurado seja espontânea. Além disso, o objeto da informação é amplo, porque, além dos fatos desconhecidos do segurador e conhecidos do segurado, exige a revelação daqueles que este deveria saber. ${ }^{740}$

disclose the circumstances on which his declaration is based; he may subsequently disclose further circumstances as grounds for his declaration if the time limit in accordance with the first sentence has not yet expired.

(2) In the event of a withdrawal in accordance with section 19 (2) after the occurrence of the insured event, the insurer shall not be obligated to effect payment, unless the breach of the duty of disclosure refers to a circumstance which is neither responsible for the occurrence or for the establishment of the occurrence of the insured event nor for the establishment or the extent of the insurer's liability. If the policyholder has fraudulently breached the duty of disclosure, the insurer shall not be obligated to effect payment.

(3) The rights of the insurer in accordance with section 19 (2) to (4) shall lapse five years after the contract expires; this shall not apply to insured events which occurred prior to the expiry of this time limit. If the policyholder has breached the duty of disclosure intentionally or by acting fraudulently, this period shall be ten years.

${ }^{737}$ Analisamos no capítulo anterior o equívoco desta aplicação da lei.

${ }^{738}$ Art. 429. Nulidade do seguro por inexactidões ou omissões.

Toda a declaração inexacta, assim como toda a reticência de factos ou circunstâncias conhecidas pelo segurado ou por quem fez o seguro, e que teriam podido influir sobre a existência ou condições do contrato tornam o seguro nulo.

§ único. Se da parte de quem fez as declarações tiver havido má fé o segurador terá direito ao prémio.

${ }^{739}$ GOMES, Júlio. O dever de informação do tomador do seguro na fase pré-contratual. In: MARTINS, M. Costa; MOREIRA, António. II Congresso Nacional de Direito dos Seguros - memórias. Coimbra: Almedina, 2001. p. 86.

${ }^{740}$ Id. Ibid., p. 83-84. 


\section{Reino Unido}

O sistema jurídico britânico confere a máxima proteção ao segurador em relação à informação a que faz jus. Sem cogitar do elemento subjetivo da eventual omissão ou inexatidão das informações prestadas pelo segurado, exige dele a espontânea revelação de todos os fatos relevantes para a apreciação do risco pelo segurador, não se restringindo, pois, às respostas constantes do questionário deste ${ }^{741}$.

Quanto ao conteúdo, para caracterizar infração ao dever de informar, basta que as omissões ou distorções se refiram a circunstância relevante para a apreciação do risco, sem necessidade de comprovação de que o segurador teria sido induzido a contratar ou a fazê-lo sob condições diversas do que faria se soubesse a verdade sobre o risco.

O aspecto da relevância da informação omitida ou distorcida foi objeto de discussão doutrinária e hesitação jurisprudencial. Prevaleceu o critério do aludido teste do segurador prudente, até que a decisão do caso Pan Atlantic Insurance Co. v. Pine Top Insurance $\mathrm{Co}^{742}$, inaugurou um novo paradigma, que exigia do segurador a prova da efetiva indução em erro pela omissão ou distorção da informação do proponente. ${ }^{743}$ Mas subsiste até hoje no direito do Reino Unido a presunção absoluta da relevância da informação omitida ou distorcida, se tiver constado de questionário formulado pela seguradora ${ }^{744}$. Não se exige comprovação do nexo de causalidade entre o fato omitido ou distorcido e o sinistro, e, apesar de críticas da doutrina, não há indícios de mudança de perspectiva ${ }^{745}$.

\footnotetext{
${ }^{741}$ Art. 18 MIA. Disclosure by assured.

(1) Subject to the provisions of this section, the assured must disclose to the insurer, before the contract is concluded, every material circumstance which is known to the assured, and the assured is deemed to know every circumstance which, in the ordinary course of business, ought to be known by him. If the assured fails to make such disclosure, the insurer may avoid the contract.

(2) Every circumstance is material which would influence the judgment of a prudent insurer in fixing the premium, or determining whether he will take the risk.

(3) In the absence of inquiry the following circumstances need not be disclosed, namely:

(a) Any circumstance which diminishes the risk;

(b) Any circumstance which is known or presumed to be known to the insurer. The insurer is presumed to know matters of common notoriety or knowledge, and matters which an insurer in the ordinary course of his business, as such, ought to know;

(c) Any circumstance as to which information is waived by the insurer;

(d) Any circumstance which it is superfluous to disclose by reason of any express or implied warranty.

(4) Whether any particular circumstance, which is not disclosed, be material or not is, in each case, a question of fact.

(5)The term "circumstance" includes any communication made to, or information received by, the assured. ${ }^{742}$ (1994) 3 W.L.R. 677, p. 711-712.

${ }^{743}$ Este histórico da evolução do dever de informar no contrato de seguro é detalhado em TARR, Julie-Anne. op. cit.; e PARK, Semin. op. cit.

${ }^{744}$ PARK, Semin. op. cit., p. 78-79.

${ }^{745}$ GOMES, Júlio. op. cit., p. 75-113.
} 


\section{Estados Unidos}

No seguro marítimo o direito norte-americano é semelhante ao britânico, mas, no terrestre, o dever de informar vem sendo mitigado na aplicação da lei. A anulação do contrato por omissão ou inexatidão na declaração de risco depende de prova de fraude. Isto significa que ao segurador incumbe provar que o segurado sabia da relevância da informação omitida ou distorcida. Mas, se esta for claramente relevante em relação ao risco, já induz presunção de fraude ${ }^{746}$. Presumem-se irrelevantes as informações não constantes do questionário. E, no seguro de vida, a cláusula de incontestabilidade impede que o contrato de seguro seja anulado, depois de um ou dois anos de vigência, conforme a jurisdição, mesmo em caso de fraude.

\section{Brasil. Regime Legal do Dever de Informação no Contrato de Seguro}

\section{Disciplina das declarações do proponente}

Três normas tratam implícita ou explicitamente do dever de informar do proponente no Código Civil: o art. 765, o art. 766 e seu parágrafo único. Porém, a solução legislativa não resolve bem o problema derivado da assimetria informacional.

Não bastasse a excessiva extensão semântica da boa-fé, que a transforma em padrão exageradamente elástico, contribuindo mais para desnortear a interpretação que para orientá-la, pelos motivos expostos em capítulo anterior ${ }^{747}$, o parágrafo único do art. 766 subtrai a eficiência ${ }^{748}$ do caput, como se demonstrará.

O art. 765 do Código Civil ${ }^{749}$ estabelece padrão de conduta, conjugando estrita boafé e veracidade, exigidas no grau máximo em razão das peculiaridades do contrato de seguro.

\footnotetext{
${ }^{746}$ PARK, Semin. op. cit., p. 36.

${ }^{747}$ Cap. 3. Assimetria Informacional e as Instituições: Regime da Informação nos Contratos.

${ }^{748}$ Relembre-se que eficiência e ineficiência não são conceitos de uso privativo e exclusivo da Economia. No Direito, as normas impositivas contêm sanções, justamente porque estas funcionam como instrumentos coercitivos, tendentes a assegurar seu cumprimento, ou seja, atribuir eficiência à lei. O que se discute aqui é que se a situação que enseja a aplicação da sanção não for bem delineada, a sanção não funcionará como meio eficiente de coerção. E a lei acabará surtindo o efeito inverso, incentivando o oportunismo dos agentes.

${ }^{749}$ Art. 765. O segurado e o segurador são obrigados a guardar na conclusão e na execução do contrato, a mais estrita boa-fé e veracidade, tanto a respeito do objeto como das circunstâncias e declarações a ele concernentes. (grifamos)
} 
$\mathrm{O}$ art. 766 , caput $^{750}$ prescreve, não um padrão, mas uma regra, ao cominar objetivamente a perda do direito à garantia pela omissão ou inexatidão de informações ${ }^{751}$. Sugere, à primeira leitura, não ter cogitado da perquirição de boa-fé ou má-fé subjetivas, o que favoreceria a incisividade da regra ali contida, porque não sujeita à apreciação do elemento subjetivo.

Mas o parágrafo único do art. $766^{752}$ prevê que, se a omissão ou inexatidão da declaração (referindo-se obviamente ao caput) não resultar de má-fé do segurado, o segurador poderá rescindir o contrato ou cobrar a diferença do prêmio, mesmo depois da ocorrência do sinistro. Em outras palavras, o parágrafo único estabelece uma condição caracterizada pela expressão se a omissão ou inexatidão não decorrer de má-fé (e aí só pode ser subjetiva), que viabilizará duas soluções diversas da do caput. A interpretação do parágrafo só pode levar à conclusão de que este excepciona o caput, na hipótese de o proponente ter omitido ou distorcido a verdade, mas de boa-fé.

Embora se compreenda que a norma do parágrafo foi estabelecida por equidade, ela restringe demais o alcance do caput, que só se aplicará à omissão e distorção de má-fé, o que evidentemente dificulta ou até inviabiliza a prova e abre uma via de fácil escape ao oportunismo do declarante, porque anula a objetividade da regra do caput.

Tendo o parágrafo único ao art. 766 concedido à seguradora a faculdade de resolver o contrato ou cobrar a diferença do prêmio, no caso de omissão ou inexatidão de boa-fé, cumprido este requisito subjetivo, a conduta do segurado não poderá subsumir-se à regra do caput, sob pena de não se distinguirem as condutas de boa e de má-fé. E o propósito do parágrafo único foi exatamente distingui-las para atribuir à omissão ou inexatidão de boafé efeito diverso da de má-fé, que acabou relegada ao caput.

A previsão de que a seguradora 'terá direito a' só se aplica, evidentemente, à hipótese do parágrafo, ou seja, 'se [a omissão ou inexatidão] não decorrer de má-fé'. Cumprida esta condição [boa-fé], o segurado não pode ser enquadrado no caput e, sim, no parágrafo único. Então, está claro que a escolha da seguradora no caso de boa-fé do

\footnotetext{
${ }^{750}$ Art. 766. Se o segurado, por si ou por seu representante, fizer declarações inexatas ou omitir circunstâncias que possam influir na aceitação da proposta ou na taxa do prêmio, perderá o direito à garantia, além de ficar obrigado ao prêmio vencido.

${ }^{751}$ Impondo objetivamente o dever de informar sob pena de perda da garantia, o art. 766, caput, CC, seria uma regra muito útil, porque sua objetividade e incisividade complementariam a abrangência do padrão de boa-fé do art. 765.

${ }^{752}$ Parágrafo único. Se a inexatidão ou omissão nas declarações não resultar de má-fé do segurado, o segurador terá direito a resolver o contrato, ou a cobrar, mesmo após o sinistro, a diferença do prêmio. (grifamos)
} 
segurado se limita à alternativa apresentada no parágrafo único. Portanto, a conjunção das duas normas leva a concluir que a dupla sanção de perda da garantia e do prêmio pago dependerá da comprovação da má-fé do segurado.

Há ainda a questão da escolha entre as duas sanções do parágrafo. Pela literalidade do dispositivo, a opção deveria ser faculdade da seguradora. Todavia, há interpretação segundo a qual não se trata de escolha do segurador, mas, sim, de aplicação do critério da relevância da informação incompleta ou incorreta: se, com informação correta e completa, o contrato não teria sido celebrado, caberá resolução; porém, se, sem a omissão ou inexatidão, o seguro teria sido contratado, mas em condições diversas, caberia a cobrança da diferença do prêmio ${ }^{753}$.

A legislação estrangeira, mesmo quando distingue a omissão e a inexatidão intencionais das culposas, dirime a questão de forma mais técnica e eficiente. A diferença é que, a par de atribuir efeitos diversos ao dolo e à culpa, também distingue, no caso da culpa, entre as hipóteses em que a falha informacional foi constatada antes e depois da ocorrência do sinistro. Em caso de dolo, o efeito é o mesmo: perda da garantia e do prêmio vencido. Mas em caso da culpa, e não tendo ocorrido o sinistro, a seguradora terá direito a propor majoração do prêmio ou outra alteração nas bases do negócio, e, se o segurado não aceitar, ela poderá resolver o contrato. E, ainda na hipótese de culpa, se a seguradora descobrir a falha informacional depois da ocorrência do sinistro, a solução será reduzir a indenização proporcionalmente ao prêmio pago ${ }^{754}$. Esta solução é tecnicamente mais correta e não dá margem à impunidade que o nosso art. 766, § único permite. Prevê efeitos mais gravosos para o caso de a seguradora descobrir a falha de informação depois do sinistro, como sempre acontece, pois é na ocorrência do evento danoso que emergem as circunstâncias indicativas de omissão ou inexatidão nas declarações de risco. E permite, nessas hipóteses, que a seguradora reduza proporcionalmente a indenização ${ }^{755}$, pois a

\footnotetext{
${ }^{753}$ TZIRULNIK, Ernesto; CAVALCANTI, Flávio de Queiroz. B.; PIMENTEL, Ayrton. op. cit., p. 76.

${ }^{754}$ COUILBAULT, François; ELIASHBERG, Constant; LATRASSE, Michel. op. cit., p. 94-95. Os autores fazem um demonstrativo do cálculo das duas hipóteses de culpa, referente a falha informacional descoberta antes e depois do sinistro. No $1^{\circ}$ a equação se refere à majoração proporcional do prêmio e, na segunda, à redução proporcional da indenização.

${ }^{755}$ Article L113-9. L'omission ou la déclaration inexacte de la part de l'assuré dont la mauvaise foi n'est pas établie n'entraîne pas la nullité de l'assurance.

Si elle est constatée avant tout sinistre, l'assureur a le droit soit de maintenir le contrat, moyennant une augmentation de prime acceptée par l'assuré, soit de résilier le contrat dix jours après notification adressée à l'assuré par lettre recommandée, en restituant la portion de la prime payée pour le temps où l'assurance ne court plus.
} 
sanção correspondente ao pagamento da diferença do prêmio após a materialização do risco incentiva o segurado a omitir ou mentir. Com isso ele terá uma estratégia dominante: poderá distorcer as informações relativas ao risco, porque dolo será impossível provar, e a culpa acarretará apenas a cobrança da diferença do prêmio, e, assim mesmo, só se ocorrer o sinistro, porque, via de regra, a seguradora não conseguirá descobrir a omissão ou inexatidão antes do evento danoso. A lamentável constatação é que a lei assim aplicada ironicamente induz à conclusão de que compensa afrontá-la.

Outro problema relativo ao parágrafo único do art. 766, não decorre propriamente da lei, mas de sua aplicação. Consiste no argumento de que a boa-fé se presume, revertendo o ônus da prova da má-fé para o segurador.

A ineficiência da norma do parágrafo único ao art. 766 é agravada por interpretação doutrinária $^{756}$ e jurisprudencial, que traduz a má-fé implícita no caput, por "intuito de lesionar a seguradora”. Essa exegese a transforma numa excludente aplicável a toda e qualquer ocultação ou distorção de informação, porque nenhuma conduta, por mais omissa ou falsa que fosse, implicaria um grau de cinismo tal que permitisse a prova deste específico intuito, pois é o tipo de intenção que só seria descoberta se confessada, o que ninguém faria. O elemento subjetivo visto assim, como intenção de lesar a vítima, só é compatível com o direito penal.

No direito privado, nenhuma intenção específica é necessária para caracterizar máfé na prática do ilícito. Para configurá-la é suficiente a simples intenção de ocultar ou de distorcer a verdade. E para demonstrá-la basta comprovar que o segurado tinha conhecimento da informação sonegada ou distorcida e poderia supor que sua revelação acarretaria aumento do preço da garantia. Isto já mostra que ele sabia da relevância da informação para a parte contrária e é aí que está a intenção da prática do ato. Mais que suficiente para demonstrar o oportunismo. Não seria necessário, portanto, a comprovação do intuito específico de lesar a contraparte com a omissão ou distorção da verdade.

Ao segurador cabe apenas provar a ocorrência da omissão ou inexatidão e a relação desta com o risco garantido. Ao segurado incumbem as demais provas, pois existe a presunção de que ele tem conhecimento dos atributos de seu risco, e de que teria, em tese, interesse de ocultar fatos passíveis de aumentá-lo, acarretando aumento do preço do

Dans le cas où la constatation n'a lieu qu'après un sinistre, l'indemnité est réduite en proportion du taux des primes payées par rapport au taux des primes qui auraient été dues, si les risques avaient été complètement et exactement déclarés.

${ }^{756}$ TZIRULNIK, Ernesto; CAVALCANTI, Flávio de Queiroz. B.; PIMENTEL, Ayrton. op. cit., p. 76. 
seguro, porque, ainda que intuitivamente, é fácil saber que o prêmio é medido pelas dimensões do risco.

Não se afigura correto o argumento de que a boa-fé se presume, revertendo o ônus da prova da má-fé para o segurador. A questão é que a boa-fé não pode ser presumida em face de outra presunção que lhe é logicamente antecedente: a de que o segurado tem conhecimento das peculiaridades do risco incidente sobre seu interesse, e sabe que deve descrevê-las corretamente ao segurador, e, por isso, é ele que deve provar por que não o fez. E essa prova de seus motivos concerne ao elemento subjetivo. Embora a presunção aludida seja de fato e não de direito, a doutrina é unânime em reconhecê-la, presumindo o conhecimento exclusivo do segurado em relação aos fatos que envolvem o risco contra o qual pretende se garantir, e a ciência de que deve informá-los ao descrever o risco na contratação do seguro. Mas, apesar disso, não extrai da presunção o efeito a ela inerente. Em se tratando de presunção relativa, comporta prova em contrário a cargo da parte contra a qual é estabelecida: o segurado. Esta solução evita o ônus absurdo de uma parte ter que provar a intenção da outra.

Nesse caso da distribuição do ônus da prova, o equívoco não está na lei, mas na sua interpretação. A imposição do ônus da prova pela jurisprudência ao segurador, neste caso, afronta a técnica exegética e cria ineficiência, pois torna a punição da ocultação ou da inverdade praticamente impossível diante da dificuldade procedimental.

Apontando o custo excessivo da obtenção e verificação das informações do segurado pela seguradora, o que a obriga a confiar nas declarações do segurado, FabreMagnan sustenta que a dificuldade de produção de prova restringe demais o direito do credor da informação ${ }^{757}$.

Em suma, o parágrafo único flexibilizou de tal forma a regra do caput do art. 766, que a aplicação da respectiva sanção fica à mercê do bom-senso do aplicador da lei.

${ }^{757}$ FABRE-MAGNAN, Muriel. op. cit., p. 105. 


\section{Disciplina do dever de informar no curso do contrato}

\section{Comunicação do agravamento do risco $^{758}$}

O dever de comunicar todo incidente suscetível de agravar consideravelmente o risco coberto é corolário do princípio da proporcionalidade risco-prêmio, que impõe a correspondência entre esses dois fatores já que um é parâmetro e medida do outro e sua equivalência protege o fundo mútuo organizado e administrado pela seguradora.

Como o seguro é contrato de trato sucessivo que se deve adaptar às circunstâncias no decurso de sua vigência ${ }^{759}$, o dever de informar é dinâmico e contínuo ${ }^{760}$. Condições que possam provocar significativo aumento da probabilidade ou da intensidade do risco devem ser imediatamente reportadas ao segurador, sob pena de perda do direito à garantia, se intencionalmente ocultadas.

A severidade da sanção se deve à natureza do contrato de seguro e às peculiaridades de seu mecanismo, que exige a manutenção da proporcionalidade entre risco e prêmio durante todo o período de vigência do contrato, para que não se quebre seu equilíbrio ${ }^{761}$. Como os prêmios calculados de acordo com os riscos declarados na fase de formação do contrato compõem o fundo comum, que arcará com as indenizações dos eventuais sinistros, se não se mantiver a correspondência entre risco e prêmio no curso do contrato, os recursos do fundo ficarão defasados, e arcarão com riscos maiores do que os prêmios coletados. Isso expõe a mutualidade a riscos mais graves, e o fundo comum poderá não ser suficiente para arcar com as indenizações.

Halperín distingue três sistemas normativos aplicados ao dever de informar a agravação do risco: a espontânea, como no direito italiano e alemão; a limitada ao questionário; e uma forma intermediária, que exige espontaneidade da declaração, mas

\footnotetext{
${ }^{758}$ Art. 769. O segurado é obrigado a comunicar ao segurador, logo que saiba, todo incidente suscetível de agravar consideravelmente o risco coberto, sob pena de perder o direito à garantia, se provar que silenciou de má-fé.

$\S 1^{\circ}$ O segurador, desde que o faça nos quinze dias seguintes ao recebimento do aviso da agravação do risco sem culpa do segurado, poderá dar-lhe ciência, por escrito, de sua decisão de resolver o contrato.

$\S 2^{\underline{0}}$ A resolução só será eficaz trinta dias após a notificação, devendo ser restituída pelo segurador a diferença do prêmio.

${ }^{759}$ PICARD e BESSON ponderam que, sendo o seguro "un contrat successif, destiné à procurer la sécurité elle doit donc, pour remplir son but dans le temps, s'adapter aux circonstances, se modeler sur le risque. PICARD, Maurice; BESSON, André. op. cit., p. 118.

${ }^{760}$ GHERSI, Carlos Alberto. Contrato de seguro. Buenos Aires: Astrea, 2007. p. 167.

${ }^{761}$ GARRIGUES, Joaquín. op. cit., p. 212.
} 
com indicação na apólice das agravações tidas como relevantes pelo segurador ${ }^{762}$. O autor considera melhor este sistema misto, porque reune as vantagens dos outros dois, orientando o segurado com base no questionário, mas sem impor ao juiz o juízo de relevância do segurador, quando a circunstância a declarar não for realmente importante ${ }^{763}$. Parece-nos, porém, não ser esta a melhor solução, pois questões técnicas se devem deixar a cargo de especialistas e não dos juízes, justificadamente não versados na matéria, que exige conhecimentos profundos de áreas diversas da jurídica. Mormente se a relevância já tiver sido estabelecida a priori na apólice, não deixando ao segurado margem para dúvidas. Ele só terá que cumprir a cláusula contratual.

No nosso sistema jurídico, a comunicação exigida é espontânea, e não se resume às circunstâncias cogitadas no questionário, embora este deva servir de predeterminação do critério de relevância do segurador. Mas como dissemos anteriormente, o questionário não pode constituir presunção absoluta, porque é impossível, mesmo considerando a expertise da seguradora, que esta possa prever toda a variedade de situações fáticas aptas a agravar consideravelmente o risco, às quais só o segurado tem acesso.

Os efeitos do descumprimento do dever de informar são a perda do direito à garantia, em caso de silêncio intencional (caput). Não há no Código Civil previsão para o caso de omissão culposa do segurado, pois o parágrafo $1^{\circ}$ ao art. 769 cuida da agravação culposa, e não da falta de comunicação do fato gerador.

Quanto ao elemento subjetivo valem as considerações feitas em relação às declarações de risco a cargo do proponente.

\section{Comunicação da ocorrência do sinistro ${ }^{764}$}

A razão da exigência da comunicação imediata do sinistro, sob pena de perda do direito à indenização, é permitir à seguradora apurar melhor suas causas e tomar

\footnotetext{
${ }^{762}$ HALPERIN, Isaac. op. cit., p. 275. O autor considera melhor o sistema misto porque reúne as vantagens dos outros dois, orientando o segurado com base no questionário, mas sem impor ao juiz o juízo de relevância do segurador

${ }^{763}$ Id. Ibid.

${ }^{764}$ Art. 771. Sob pena de perder o direito à indenização, o segurado participará o sinistro ao segurador, logo que o saiba, e tomará as providências imediatas para minorar-lhe as conseqüências.

Parágrafo único. Correm à conta do segurador, até o limite fixado no contrato, as despesas de salvamento conseqüente ao sinistro.
} 
providências necessárias para minorar o dano e avaliar o montante indenizatório correspondente $^{765}$.

A severidade da sanção ao descumprimento do dever de comunicação imediata do sinistro se justifica porque o lapso temporal entre este e o aviso poderá impedir ou dificultar a apuração das causas do evento, o que é de suma importância para o segurador, além de impedi-lo de, quando possível, atenuar os efeitos do sinistro.

\section{Observações finais}

Em síntese, as considerações gerais traçadas em relação ao dever de informar no direito contratual se aplicam aqui com mais rigor, em razão das peculiaridades do mecanismo do seguro e da importância e alcance das funções por ele exercidas.

${ }^{765}$ GARRIGUES, Joaquín. op. cit., p. 220. 


\section{CONCLUSÃO}

Este estudo buscou um enfoque interdisciplinar do tema, investigando-o sob a perspectiva da análise econômica do Direito e da análise tradicional, por entender que uma complementa a outra ${ }^{766}$. A aplicação de algumas constatações da Economia e da Psicologia a respeito de informação, incerteza, risco, e do processo de tomada de decisão, assim como de noções básicas de estratégia, emprestadas da Teoria dos Jogos e destinadas a explicar a escolha dos agentes, permite visão multifacetada da realidade, como, de fato, ela é. E sendo o contrato uma das áreas que melhor evidenciam a intersecção dessas disciplinas, oferece contexto propício à sua aplicação conjunta.

A perquirição do papel da informação que permeia o contrato induziu à conclusão de que, se funcionar como atributo de um elemento essencial, com este se confunde, passando a integrá-lo, e como tal deve ser tratado pelo Direito. Pode afetar a tomada de decisão das partes e a legitimidade do consentimento, ou contribuir para que o contratante mais informado extraia, devida ou indevidamente, mais ganhos do contrato.

Definida a função da informação nesse contexto, e analisada sua distribuição entre os agentes, discutiram-se critérios da disciplina de situações em que a assimetria informacional gera efeitos nocivos, como custos de transação muito elevados, e desequilíbrio na repartição de ganhos auferidos do contrato, não comportando soluções de mercado.

Questionou-se a utilidade da boa-fé como padrão eficiente para disciplinar a informação nos contratos. Embora padrões sejam necessários para alcançar condutas inatingíveis pelas regras, que são mais incisivas, e, por isso, menos abrangentes, a ambiguidade e plurivocidade da boa-fé, sua carga emotiva e inata subjetividade ${ }^{767}$ traem o objetivo a que foi proposta. Incitando o intérprete a preencher-lhe o conteúdo de acordo com seus próprios valores morais, religiosos, ideológicos, cria insegurança jurídica. Ao

\footnotetext{
${ }^{766}$ Esta dinâmica de interação e complementaridade entre Economia e Direito e outras ciências sociais, foi reconhecida há muito tempo, como se infere da observação de Ripert, sugerindo que essas ciências não deveriam ser tratadas como departamentos estanques, e lamentando o divórcio entre elas: " $C$ ' est le divorce absolut qui serait à mes yeux déplorable. Les juristes ne sauraient appliquer, ni interpréter les régles de droit s'ils ne connaissent pas l'économie et la sociologie." Vislumbrando a recíproca influência entre Direito e Economia, cita Pirou, para afirmar que "Les règles juridiques forment le premier élément du cadre de la vie économique", e, invoca Murat, asseverando que "le cadre juridique commande dans une certaine mesure les choix économiques". RIPERT, Georges. Aspects juridiques du capitalisme moderne. Paris: Librairie Générale de Droit et de Jurisprudence, 1951. p. 4-5.

${ }^{767} \mathrm{~A}$ despeito de ter sido rotulada, neste caso, como objetiva.
} 
concederem larga margem de discricionariedade ao julgador, normas de tipo aberto, como a boa-fé, atribuem poder demais ao Estado em detrimento da autonomia privada, além de desestimularem o cumprimento da lei, por lhes faltar a incisividade que induz certeza e, consequentemente, operacionalidade.

Da perquirição zetética ${ }^{768}$ do dogma da boa-fé se concluiu que devem ser destacados de seu conceito os deveres que ela engloba, para aplicá-los como institutos autônomos, relegando-a a uma função residual. Do leque de deveres por ela englobados, interessa ao tema o dever de informar, que permite abordagem mais segura da disciplina da informação nos contratos, pois não carrega as incongruências intrínsecas da boa-fé, e é mais objetivo, porque despojado de fatores psicoemotivos, traduzindo melhor os atributos indispensáveis da relação contratual: confiança e confiabilidade.

Confiança é a utilização racional da informação ${ }^{769}$ e, portanto a pressupõe. Estimula negócios, permite a previsão de resultados, e promove segurança.

A crescente complexidade e impessoalidade das relações comerciais, o alargamento da esfera de atuação dos agentes que impôs distância entre as partes, a padronização dos contratos, a assimetria informacional, características inerentes à economia atual, incentivam o oportunismo e desestimulam o comprometimento das partes, exigindo atuação mais eficiente das instituições. Esses fatores conferem ao Direito maior importância, pois dele exigem a redução da incerteza, a promoção da confiança entre os agentes e a garantia da segurança jurídica.

A despeito da questionável eficiência da boa-fé como indutora da troca de informações entre as partes, foi o padrão de conduta escolhido pelo sistema jurídico para balizar a interação dos contratantes, com a presumível finalidade de desestimular o oportunismo, incentivar a cooperação e o comprometimento dos agentes e assegurar a

\footnotetext{
${ }^{768}$ Zetética, termo cunhado por Theodor Viehweg, deriva do grego zetein, traduzido por perquirir, é método de investigação científica que focaliza mais as indagações do que as respostas, e não se prende a premissas absolutas e inatacáveis, que mesmo lhes servindo de ponto de partida, são susceptíveis de serem questionadas. Sempre aberto a críticas e mudanças, opõe-se à dogmática, derivado de dokein, que significa doutrinar, e é método mais fechado, preso a conceitos predeterminados, que não são questionados, porque erigidos a postulados absolutos. Tércio Ferraz retomou a distinção entre a zetética e a dogmática, mostrando que a dogmática jurídica parte de premissas indiscutíveis, ou pelo menos temporariamente estáveis, e vinculantes para o estudo, implicando, assim, renúncia ao postulado da pesquisa independente. $\mathrm{O}$ estudo dos fenômenos comporta a combinação dos dois métodos, mas sempre com a preponderância de um deles. Os juristas também se valem do método zetético, mas recorrem mais à dogmática, porque tendem a buscar respostas às indagações sempre dentro dos marcos da ordem jurídica vigente. FERRAZ JR., Tércio Sampaio. Introdução ao estudo do direito: técnica, decisão, dominação. 6. ed. São Paulo: Atlas, 2011. p. 18-25, passim..

${ }^{769}$ MACKAAY, Ejan; ROUSSEAU, Stéphane. op. cit., p. 385.
} 
confiança recíproca. E quanto mais assimétrica a distribuição da informação no contrato, e mais nocivos os efeitos dessa disparidade, maior a exigência de boa-fé dos contratantes, até o grau máximo concebido para os contratos uberrimae fidei, que impõem às partes a mais estrita transparência e veracidade.

Se a informação representa papel relevante nas relações contratuais em geral, no contrato de seguro é indispensável, por ser elemento essencial e necessário à determinação do risco a ser garantido e à fixação do prêmio. As peculiaridades do contrato de seguro recomendam maior controle da informação que o instrui, porque a assimetria informacional tende a aumentar demais os custos de transação e causar externalidades negativas para a comunidade de segurados, atingindo, por via reflexa, toda a sociedade. Não por acaso, o contrato de seguro é classificado como de máxima boa-fé, em todos os sistemas jurídicos de Common e Civil Law, revelando a importância da informação nesse tipo contratual.

Sua característica mais relevante é a uberrima fides, ou máxima boa-fé. Como a honestidade e a ética, a boa-fé não comportaria, em tese, a gradação sugerida pelo superlativo, porque não faria sentido ser ligeiramente honesto e nem honestíssimo, pois quem não é $100 \%$ honesto, é desonesto. Assim, só se pode concluir que o superlativo que distingue a boa-fé nesse contrato é usado para enfatizar a imprescindibilidade de total transparência e absoluta veracidade, as quais se resumem no dever de informar, corolário do princípio da boa-fé.

De acordo com o padrão que modela o contrato de seguro, o segurado têm o dever de informar todos os fatos e circunstâncias aptos a afetar o risco, desde que, obviamente, dele conhecidos, ainda que a informação não tenha sido requisitada. Como o segurado evidentemente sabe muito mais do risco incidente sobre seu próprio interesse do que o segurador, este dependerá das informações dele para a classificação do risco, as quais servirão de balizas para sua aceitação e para a tarifação do prêmio. Embora o dever de informar seja recíproco, vinculando também o segurador à transparência e à verdade, pela própria natureza e função do contrato de seguro, a maior nocividade da assimetria informacional é a que desfavorece o segurador, pois não afeta somente este, mas também a mutualidade.

Se a regra é a máxima transparência e a absoluta veracidade, traduções do princípio da boa-fé superlativa, como sugerem a literalidade da lei e a interpretação sistemática das normas jurídicas atinentes ao instituto, deverá ser restritiva a interpretação 
das exceções a este princípio, sejam estas legalmente previstas ou jurisprudencialmente criadas ${ }^{770}$. Qualquer extravagância ou condescendência na exegese de eventuais omissões ou distorções da verdade afrontaria o princípio da máxima boa-fé que norteia a interpretação do contrato de seguro, o qual, se mitigado, abdicaria do superlativo que o distingue dos demais tipos contratuais, em relação aos quais a lei exige somente a boa-fé 'não-qualificada'. A uberrima fides, como atributo inerente à própria natureza desse tipo contratual, não comporta, a nosso ver, mitigação, sob pena de descaracterização do contrato. E, como a informação se prende ao cerne da operação econômica subjacente, afetando o cálculo do risco e a fixação do prêmio, e consequentemente, a mutualidade, diz respeito à função e à finalidade do instituto. Por isso, a interpretação teleológica também conduz à mesma conclusão, pois interpretar com benevolência o dever de informar, relevando seu descumprimento, compromete o equilíbrio do contrato de seguro e afeta sua finalidade sócio-econômica.

Analisaram-se as premissas que orientam o dever de informar no contrato de seguro, e discutiram-se os critérios legais para sua aplicação, demonstrando-se sua inadequação em relação ao substrato econômico do contrato. Não faria sentido a exigência de comprovação da má-fé para caracterizar infração legal decorrente das omissões ou distorções da verdade, se tivesse sido expressamente adotado o dever de informar e não o padrão de boa-fé. A caracterização da quebra do dever dependeria objetivamente da falta de transparência e de veracidade, independentemente do elemento subjetivo.

Questionou-se também a aplicação dogmática da boa-fé segundo a qual esta sempre se presume e reverte o ônus da prova, mesmo diante de outra presunção que lhe é logicamente antecedente: a de que o segurado conhece - ou deve conhecer - o risco incidente sobre seu próprio interesse, e sabe que deve descrevê-lo corretamente ao segurador, e, por isso, é ele que deve provar por que não o fez. E essa prova de seus motivos concerne ao elemento subjetivo. Reconsiderada a distribuição do ônus da prova, não se exigiria do segurador a absurda comprovação da má-fé da contraparte. A ele caberia apenas provar a ocorrência da omissão ou inexatidão e a relação desta com o risco garantido.

Em suma, se a informação é base para a mensuração do risco e fixação do prêmio, a exigência de máxima transparência e veracidade é medida de proteção do fundo mútuo.

\footnotetext{
${ }^{770}$ A rigor, por essa linha de raciocínio, nem poderiam ser criadas exceções pela jurisprudência. Temos, porém, que admiti-las na argumentação, porque já existem.
} 
Por isso, não comporta as concessões permitidas pela lei nem a excessiva condescendência na sua aplicação, sob pena de incentivar o oportunismo dos agentes, antes e depois da contratação, aumentando os custos de transação e gerando externalidades. 


\section{REFERÊNCIAS BIBLIOGRÁFICAS}

ABRAHAM, Kenneth. Insurance law and regulation. 4. ed. New York: Foundation Press, 2005 .

AKERLOF, George A. The market for 'lemons': quality uncertainty and the market mechanism. The Quarterly Journal of Economics, v. 84, n. 3, p. 488-500, Aug, 1970.

ALEXY, Robert. Teoria dos direitos fundamentais. Trad. Virgílio Afonso da Silva. São Paulo: Malheiros Ed., 2008.

ALMEIDA, José Carlos Moitinho de. O contrato de seguro no direito português $e$ comparado. Lisboa: Sá da Costa Ed., 1971.

ALVES, Francisco Kummel Ferreira; TIMM, Luciano Benetti. Custos de transação no contrato de seguro: proteger o segurado é socialmente desejável? In: TIMM, Luciano Benetti (Org.). O novo direito civil: ensaios sobre o mercado, a reprivatização do direito civil e a privatização do direito público. Porto Alegre: Livr. do Advogado, 2008. p. 113130 .

ALVIM, Pedro. O contrato de seguro. 3. ed. Rio de Janeiro: Forense, 1999.

ARAÚJO, Fernando. Teoria económica do contrato. Coimbra: Almedina, 2007.

ARROW, Kenneth J. The essays in the theory of risk bearing. Chicago: Markham, 1971.

Information and economic behavior. In: The economics of information. MA: Belknap Press Harvard University, 1984. (Collected Papers of Kenneth Arrow, v. 4). Insurance, risk and resource allocation. Reimpr. de Aspects of the theory of risk bearing. MA: Belknap Press Harvard University, 1984. (Collected Papers of Kenneth Arrow, v. 4, Economics of Information).

ATHEARN, L.; PRITCHETT, S. Travis; SCHMIT, Joan T. Risk and insurance. $6^{\text {th }}$ ed. MN: West Publishing Company, 1989.

ATIYAH, Patrick S. An introduction to the law of contract. $5^{\text {th }}$ ed. Oxford: Oxford University Press, 1995.

BAIRD, Douglas G., GERTNER, Robert H.; PICKER, Randal C. Game theory and the law. Harvard University Press, 1998. 
BEATSON, Jack; FRIEDMANN, Daniel. Introduction: from 'classical' to modern contract law. In: BEATSON, Jack; FRIEDMANN, Daniel (Eds.). Good faith and fault in contract law. 1995, rep. 2002. Oxford: Claredon Press, 2002.

BENINI, Stefano. In: LA TORRE, Antonio (a cura di). Le assicurazioni. 2. ed. ampl. e agg. Milano: Giuffrè, 2007.

BERNSTEIN, Peter. Desafio aos deuses, a fascinante história do risco. 23. ed. Trad. Ivo Korylowski do original Againt the gods. Rio de Janeiro: Elsevier, 1997.

BESSONE, Darci. Teoria geral do contrato. Rio de Janeiro: Forense, 1987.

BETTI, Emilio. Teoria generale delle obbligazioni: prolegomeni, funzione economicosoziale dei rapporti d'obbligazione. Milano: Giuffrè. 1953. v. 1.

Teoria geral do negócio jurídico. Trad. Fernando de Miranda. Coimbra: Coimbra Ed., 1969. t. 1.

BEVILÁQUA, Clóvis. Código Civil comentado. Rio de Janeiro: Francisco Alves, 1953. v. 5.

BIANCA, Massimo. Diritto civile: il contratto. 2. ed. Milano: Giuffrè, 2000. v. 3.

BOBBIO, Norberto. Da estrutura à função: novos estudos de teoria do direito. Trad. de Daniela Beccaccia Versiani. São Paulo: Manole, 2007.

BRADLEY, Ger, CORRY, Dermot, BURNS, Keith. Impact of ECJ Judgement. Disponível em: $<$ https://web.actuaries.ie/sites/default/files/event/2011/03/110315\%20Gender\%20Directive.pdf>.

BRAUCHER, R. Interpretation and legal effect in the second restatement of contracts. Columbia Law Review, n. 81, p. 13-18, 1981.

BRIDGE, Michael. Does anglo-canadian contract law need a doctrine of good faith? Canadian Business Law Journal / Revue Canadienne de Droit des Affaires, n. 9, p. 385426, 1984.

BURTON, Steven J. Breach of contract and the common law duty to perform in good faith. Harvard Law Review, n. 94, p. 369-404, 1980-1981.

Good faith performance of a contract within Article 2 of the Uniform Commercial Code. Iowa Law Review, n. 67, p. 1-30, 1981-1982.

CALABRESI, Guido. The costs of accidents, a legal and economic analysis. New Haven: Yale University Press, 1970. 
CALMON DE PASSOS, J. J. A atividade securitária e sua fronteira com os interesses transindividuais - responsabilidade da SUSEP e competência da Justiça Federal. Revista dos Tribunais, São Paulo, ano 88, v. 763, p. 95-102, maio 1999.

CANARIS, Claus-Wilhelm; GRIGOLEIT, Hans Christoph. Interpretation of contracts. Social Science Research Network. Disponível em: <http://ssrn.com/abstract=1537169>.

CARVALHO SANTOS, J. M. Código Civil brasileiro interpretado. Rio de Janeiro: Freitas Bastos, 1988. v. 19.

Código Civil brasileiro interpretado: parte geral. 13. ed. Rio de Janeiro: Freitas Bastos, 1933. v. 2.

CAVALCANTI, Flávio de Queiroz B. O conteúdo da prestação securitária e o contrato aleatório. Revista Brasileira de Direito do Seguro e da Responsabilidade Civil, São Paulo, p. 95-112, jan. 2009.

CICERO, Marco Túlio. Dos Deveres. Trad. Alex Martins. São Paulo: Martin Claret, 2005.

COASE, Ronald. The problem of social cost. In: COASE, Ronald. The firm, the market and the law. Chicago: The University of Chicago Press, 1988.

COHEN, George M. The negligence and opportunism tradeoff in contract law. Hofstra Law Review, v. 20, p. 941-1016, 1991-1992.

COHEN, Nili. Precontractual duties: two freedoms and the contract to negotiate. In: BEATSON, Jack; FRIEDMANN, Daniel (Eds.). Good faith and fault in contract law. 1995, rep. 2002. Oxford: Claredon Press, 2002.

COLOMBO, Sylviane. Fascism, community, and the paradox of good faith. The South African Law Journal, v. 111, n. 3, p. 482-496, 1984.

. Good faith: the law and morality. The Denning Law Journal, v. 8, n. 1, p. 23-59, 1993.

COMPARATO, Fábio Konder. Comentário a acórdão - Seguro - Cláusula de rateio proporcional - Juridicidade. Revista de Direito Mercantil, Industrial, Econômico e Financeiro, São Paulo, ano 11, n. 7, p. 102-112, 1972.

. Ensaios e pareceres de direito empresarial. Rio de Janeiro: Forense, 1978.

. O seguro de crédito: estudo jurídico São Paulo: Ed. Revista dos Tribunais, 1968.

COOTER Robert; SCHÄFER, Hans-Bernd. Desconfiança recíproca. Trad. Luciano B. Timm. In: SALAMA, Bruno Meyerhof (Org.). Direito e economia: textos escolhidos. Salama. São Paulo: Saraiva, 2010. 
COOTER, R.; ULEN, T. Law and economics. $4^{\text {th }}$ ed. Boston: Pearson Addison Wesley, 2004.

COUILBAULT, François; ELIASHBERG, Constant; LATRASSE, Michel. Les grands principes de l'assurance. 5. ed. Paris: L'Argus, 2002.

DEMSETZ, Harold. The theory of the firm revisited. Journal of Law, Economics and Organization, v. 4, n. 1, p. 141-161, 1988.

DONATI, Antigono. Trattato del diritto delle assicurazione private. Milano: Multa Pacis, 1952. v. 2.

EBKE, Werner F.; STEINHAUER, Betina M. The doctrine of good faith in german contract law. In: BEATSON, Jack; FRIEDMANN, Daniel (Eds.). Good faith and fault in contract law. 1995, rep. 2002. Oxford: Claredon Press, 2002.

EISENBERG, Melvin. Disclosure in contract law. California Law Review, n. 91. p. 16451692, 2003.

ESPÍNOLA, Eduardo. Dos contratos nominados no direito civil brasileiro. Campinas: Bookseller, 2001.

EU Gender Directive Eight MONTHS On, Association of Financial Mutuals Annual. Conference and AGM - 3-4 Nov. 2011. Disponível em: $<$ http://www.financialmutuals.org/files/files/EU\%20Gender\%20Directive.pdf>.

FABRE-MAGNAN, Muriel. Duties of disclosure and French contract law: contribution for an economic analysis. In: BEATSON, Jack; FRIEDMANN, Daniel (Eds.). Good faith and fault in contract law. 1995, rep. 2002. Oxford: Claredon Press, 2002. p. 99-120.

FARNSWORTH, E. Allan. Good faith in contract performance. In: BEATSON, Jack; FRIEDMANN, Daniel (Eds.). Good faith and fault in contract law. 1995, rep. 2002. Oxford: Claredon Press, 2002. p. 154-155.

Good faith performance and commercial reasonableness under the Uniform Commercial Code. University of Chicago Law Review, n. 30, p. 666-679, 1962-1963.

Precontractual liability and preliminary agreements: fair dealing and failed negotiations. Columbia Law Review, n. 87, p. 217-294, Mar. 1987.

FERRAZ JR., Tércio Sampaio. Introdução ao estudo do direito: técnica, decisão, dominação. 6. ed. São Paulo: Atlas, 2011.

FERREIRA, Waldemar. Tratado de direito comercial. São Paulo: Saraiva, 1963.v. 2. 
FIANI, R. Teoria dos jogos: com aplicações em economia, administração e ciências sociais. 2. ed. rev. e atual. Rio de Janeiro: Campus Elsevier, 2006.

FRADA, Manuel António de C. P. Carneiro da. Teoria da confiança e responsabilidade civil. Reimpr. da ed. de 2004. Coimbra: Almedina, 2007.

FRIEDMAN, David. Law's order: what economics has to do with law and why it matters. New Jersey: Princeton University Press, 2000.

FRONTINI, Paulo Salvador. Seguro - contrato de adesão - cláusulas limitativas de direito, que não se mostram claras e em destaque - nulidade - ocorrência - cláusula de perfil inoponibilidade - previsão de situações excludentes de indenização que não configuram, ontologicamente, agravamento de risco - limitação do prêmio a percentual previamente estabelecido - admissibilidade - inteligência dos arts. 54 do CDC, 51 e 422 a 424 do CC de 2002. Revista de Direito Mercantil, Industrial, Econômico e Financeiro, São Paulo, n. 137, p. 285-294, jan./mar. 2005.

GALGANO, Francesco. Il contratto. Verona: Cedam, 2007. . Obbligazioni in generalli, Padova: CEDAM, 2007.

GARRIGUES, Joaquín. Contrato de seguro terrestre. Madrid: La Ley, 1973.

GASPERONI, Nicola. Assicurazioni private. Torino: Unione Tipografica Editrice Torinese, 1959.

GHERSI, Carlos Alberto. Contrato de seguro. Buenos Aires: Astrea, 2007.

GOMES, Júlio. O dever de informação do tomador do seguro na fase pré-contratual. In: MARTINS, M. Costa; MOREIRA, António. II Congresso Nacional de Direito dos Seguros - memórias. Coimbra: Almedina, 2001. p. 75-113.

GOMES, Orlando. O contrato de adesão: condições gerais dos contratos. São Paulo: Ed. Revista dos Tribunais, 1972.

. Contratos. 26. ed. Coord. Edvaldo Brito. Atualizadores Antonio Junqueira de Azevedo e Francisco Paulo De Crescenzo Marino, Rio de Janeiro: Forense, 2009.

GONÇALVES, Luiz da Cunha. Da compra e venda no direito comercial brasileiro. São Paulo: Max Limonad, 1950.

HALPERIN, Isaac. Seguros. Buenos Aires: Depalma, 1976.

HAMILTON, Walton, H. The ancient maxim caveat emptor. Yale Law Journal, v. 15. n. 8. June, 1931. 
HANSMANN, Henry; KRAAKMAN, Reinier. The anatomy of corporate law, a comparative and functional approach. Oxford: Oxford University Press, 2004.

HAYEK, F. A. Economics and knowledge. Economica, New Series, v. 4, n. 13, p. 33-54, Feb. 1937.

. The use of knowledge in society. The American Economic Review, v. 35, n. 4, p. 519-530, Sept. 1945.

HESSELINK, Martijn W. The concept of good faith. In: HARTKAMP, Arthur S.; HESSELINK, Martijn W. et al (Eds.). Towards a European Civil Code. $4^{\text {th }}$ ed. rev. expan. Alphen aan de Rijn: Kluwer Law International, 2010. p. 619-649.

HIRSHLEIFER, Jack. The Private and social value of information and the reward to inventive activity. The American Economic Review, v. 61, n. 4 p. 561-574, Sep., 1971.

Where are we in the theory of information? The American Economic Review, v. 63, n. 2, p. 31-39, May, 1973.

HM TREASURY UK response to the 1 March European Court of Justice ruling that insurance benefits and premiums after 21 December 2012 should be gender-neutral: a consultation. Dec. 2011. Disponível em: <http://www.hmtreasury.gov.uk/d/condoc_insurance_benefits_and_premiums.pdf >.

HOLMSTROM, Bengt. Moral hazard and observability. The Bell Journal of Economics, v. 10, n. 1, p. 74-91, Spring, 1979.

IPPOLITO, Richard A. Economics for lawyers. New York: Princeton University Press, 2005.

JAFEE, Dwight; RUSSEL, Thomas. Imperfect information, uncertainty and credit rationing. Quarterly Journal of Economics, v. 90, n. 4, p. 651-666, nov. 1976.

JALUZOT, Béatrice. La bonne foi dans les contrats: étude comparative de droit français, allemand e japonais, Paris: Dalloz, 2001.

JHERING, Rudolf von. Culpa in contrahendo ou indemnização em contratos nulos ou não chegados à perfeição. Trad. Paulo Mota Pinto. Coimbra: Almedina, 2008.

JOURDAIN, Patrice. Contribution à l'étude de l'obligation de renseignement. Paris: Dalloz, 1983.

JUNQUEIRA DE AZEVEDO, Antonio. A boa-fé na formação dos contratos. In: NERY JR., Nelson; NERY, Rosa Maria de Andrade (Orgs.). Doutrinas essenciais: responsabilidade civil: direito das obrigações e direito negocial. 2. tir. São Paulo: Ed. Revista dos Tribunais, 2010. v. 2, p. 415-423. 
JUSTIA. US SUPREME COURT CENTER. Disponível em: $<$ http://supreme.justia.com/us/15/178/case.html>.

KAPLOW, Louis. Rules versus standards: an economic analysis. Duke Law Journal, v. 42, n. 3, p. 557-629, Dec. 1992.

KATZ, Avery W. Foundations of economic analysis of law. New York: Foundation Press, 1998.

KESSLER, Friedrich; FINE, Edith. Culpa in contrahendo, bargaining in good faith, and freedom of contract: a comparative study. Faculty Scholarship Serie. Paper 2724. Disponível em: <http://digitalcommons.law.yale.edu/fss_papers/2724>.

; Culpa in contrahendo, bargaining in good faith, and freedom of contract: a comparative study. Harvard Law Review, n. 77, p. 401-449, Jan. 1964.

KNIGHT Frank Hyneman. Risk, uncertainty and profit. Londres: Houghton Mifflin Co, 1921. Reimpresso por Nabu Public Domain Reprints, 2001. Boston: Houghton Mifflin. Knudsen, M.P., B. Dalum \& G. Villumsen, 2001.

KÖTZ, Hein. Precontractual duties of disclosure: a comparative and economic perspective. European Journal of Law and Economics, n. 9, p. 5-19, 2000.

KRONMAN, Anthony T. Mistake, disclosure, information and the law of contracts. Journal of Legal Studies, v. 7, n. 1, p. 1-33, 1978.

KRUGMAN, Paul; WELLS, Robin. Introdução à economia. Rio de Janeiro: Campos Elsevier, 2007.

LAMBERT-FAIVRE, Yvonne. Droit des assurances. 3. ed, Paris: Dalloz, 1979.

LA TORRE, Antonio (a cura di). Le assicurazioni. 2. ed. ampl. e agg. Milano: Giuffrè, 2007.

LEGRAND JR, Pierre. Pre-contractual disclosure and information: english and french law Compared. Oxford Journal of Legal Studies, v. 6, n. 3, p. 322-352, 1986.

LEVINESS, Charles T. Caveat emptor versus caveat venditor. Maryland Law Review, v. 7, n. 3. Apr. 1943.

LOFGREN, Karl-Gustaf; PERSSON, Torsten; WEIBULL, Jorgen W. Markets with asymmetric information: the contributions of George Akerlof, Michael Spence and Joseph Stiglitz. The Scandinavian Journal of Economics, v. 104, n. 2, p. 195-211, Jun. 2002.

LUHMANN, Niklas. Vertrauen - Ein Mechanismus der Reduktion sozialer Komplexität, Sttutgart: Lucius und Lucius, 2000. 
MACHO-STADLER, Ines; PEREZ-CASTRILLO, J. David. An introduction to the economics of information: incentives and contracts. London: Oxford University Press, 1997.

MACKAAY, Ejan. L'analyse économique du droit comme outil de la doctrine juridique: la bonne-foi et la justice contractuelle. Texto referente à palestra apresentada no IV Congresso da Associação Brasileira de Direito e Economia em Curitiba, 2011.

; ROUSSEAU, Stéphane. Analyse économique du droit. 2. ed. Paris: Dalloz, 2008.

MACNEIL, Ian R. Adjustment of long-term economic relations under classical, neoclassical and relational contract law. Northwestern University Law Review, n. 72, p. 854-906, 1978.

MARTINS-COSTA, Judith. A boa-fé no direito privado: sistema e tópica no processo obrigacional. 1. ed. 2. tir. São Paulo: Ed. Revista dos Tribunais, 2000.

MAYAUX, Luc. L'ignorance du risque. Revue Générale du Droit des Assurances, 1999.

MELLO FRANCO, Vera Helena de. Breves reflexões sobre o contrato de seguro no novo Código Civil brasileiro. In: FÓRUM DE DIREITO DO SEGURO JOSÉ SOLLERO FILHO. ESTUDOS DE DIREITO DO SEGURO, São Paulo: IBDS-EMTS, 2002.

_. Contratos: direito civil e empresarial. São Paulo: Ed. Revista dos Tribunais, 2009.

_ Lições de direito securitário: seguros terrestres privados. São Paulo: Maltese, 1993.

MENEZES CORDEIRO, António Manuel da Rocha e. Da boa fé no direito civil. 3. reimpr. Coimbra: Almedina, 2007.

MURIS, Timothy J. Opportunistic behavior and the law of contracts. Minnesota Law Review, v. 65, p. 521-590, 1980-1981.

MUSY, Alberto M. The Good faith principle in contract law and the precontractual duty to disclose: comparative analysis of new differences in legal cultures. Global Jurist Advances, $\quad$ v. $\quad 1, \quad$ n. $1, \quad 2000$. Disponível em: < http://www.bepress.com/gj/advances/vol1/iss1/art1>.

NELSON, Phillip. Advertising as information. Journal of Political Economy, v. 82, n. 4, p. 729-754, Jul./Aug. 1974.

Information and consumer behavior. Journal of Political Economy, n. 78, p. 311329, 1970. 
NORTH, Douglas. Institutions, institutional change and economic performance. New York: Cambridge University Press, 1990.

OLIVEIRA, Ivan Marcelo de. Curso de direito do seguro. São Paulo: Saraiva, 2008.

PARK, Semin. The duty of disclosure in insurance contract law. Dartmouth Publishing Company, 1996.

PEREIRA, Antonio Carlos Alves. Miragens e aproximação. Revista Brasileira de Direito do Seguro e da Responsabilidade Civil, São Paulo, p. 95-112, jan. 2009.

PEREIRA, Caio Mário da Silva. Instituições de direito civil. Atualização de Maria Celina Bodin de Moraes. 20. ed. Rio de Janeiro:Forense, 2004. v. 1.

Instituições de direito civil. Rio de Janeiro: Forense, 1999. v. 3.

PICARD, Maurice; BESSON, André. Les assurances terrestres en droit français. Paris: Librairie Générale de Droit et de Jurisprudence, 1964.

PINDYCK, Robert S.; RUBINFELD, Daniel L. Microeconomia. Trad. Eleutério Prado e Thelma Guimarães. 6. ed. São Paulo: Pearson, 2006.

PIZA, Paulo Luiz de Toledo. Contrato de resseguro: tipologia, formação e direito internacional. São Paulo: IBDS, 2002.

PLANIOL, Marcel; RIPERT, Georges. Traité pratique de droit civile français: contrats civils, deuxième partie. Paris: Librairie Générale de Droit et de Jurisprudence, 1932. t. 11.

; __ Traité pratique de droit civile français: obligations, premième partie.

Paris: Librairie Générale de Droit et de Jurisprudence, 1930. t. 6.

PONTES DE MIRANDA, Francisco Cavalcanti. Tratado de direito privado. Rio de Janeiro: Borsoi, 1954. v. 1.

Tratado de direito privado: parte especial. 3. ed. São Paulo: Ed. Revista dos Tribunais, 1984. t. 45.

Tratado do direito privado: parte geral. 4. ed. São Paulo: Ed. Revista dos Tribunais, 1984. t. 4.

POSENATO, Naiara. In: POSENATO, Naiara; NALIN, Paulo (Orgs.). Código Europeu dos Contratos - Projeto Preliminar - Livro I. Curitiba: Juruá, 2008.

POSNER, Richard A. Economic analysis of law. $7^{\text {th }}$ ed. New York: Aspen Publishers, 2007. 
REALE, Miguel. Boa-fé no Código Civil. Miguel Reale, 16 ago. 2003. Disponível em: $<$ www.miguelreale.com.br>.

. Espírito da nova Lei Civil. Miguel Reale, 04 jan. 2003. Disponível em: $<$ www.miguelreale.com.br $>$.

REJDA George. Principals of risk management and insurance. 10. ed. Boston, MA.: Person International Edition, 2008.

RIBEIRO, Amadeu Carvalhaes. Direito de seguros. São Paulo: Atlas, 2006.

RIPERT, Georges. Aspects juridiques du capitalisme moderne. Paris: Librairie Générale de Droit et de Jurisprudence, 1951.

La règle morale dans les obligations civiles. 4. ed. Paris: LGDJ, 1949.

ROPPO, Enzo. O contrato. Trad. Ana Coimbra e M. Januário C. Gomes. Lisboa: Almedina, 2009.

. Il contratto. Milano: Giuffrè, 2001. (Trattato di Diritto Privato a cura di Giovanni Iudica e Paolo Zatti).

ROSSETI, Marco. In: LA TORRE, Antonio (a cura di). Le assicurazioni. 2. ed. ampl. e agg. Milano: Giuffrè, 2007.

ROTHSCHILD, Michael; STIGLITZ, Joseph. Equilibrium in competitive insurance markets: an essay on the economics of imperfect information. The Quarterly Journal of Economics, v. 90, n. 4, p. 629-649, Nov. 1976.

RUDDEN, Bernard. Le juste et le inefficace pour un non-devoir de renseignements. Revue Trimestrielle de Droit Civil, Paris, n. 84, p. 91-103, 1985.

SACCO, Rodolfo. La buona fede nella fase precontratualle. In: SACCO, Rodolfo; DE NOVA, Giorgio. Il contratto. 3. ed. Torino: UTET, 2004.v. 2.

. Legal formants: a dynamic approach to comparative law. American Journal of Comparative Law, v. 39, n. 1, 1991.

. Natura e misura della responsabilità. In: SACCO, Rodolfo; DE NOVA, Giorgio. Il contratto. 3. ed. Torino: UTET, 2004.v. 2.

; DE NOVA, Giorgio. Il contratto. 3. ed. Torino: UTET, 2004. v. 1. (Collana: Trattato di diritto civile).

SCHÄFER, Hans-Bernd; OTT, Claus. The economic analysis of civil law. Massachussets: Edward Elgar Publishing, Inc., 2004. 
SCHERMAIER, Martin Joseph. Mistake, misrepresentation and precontractual duties to inform: the civil law tradition. In: SEFTON-GREEN, Ruth (Ed.). Mistake, fraud and duties to inform in European contract law. Cambridge: Cambridge University Press, 2005. (The Common Core of European Private Law).

SEFTON-GREEN, Ruth (Ed.). Mistake, fraud and duties to inform in European contract law. Cambridge: Cambridge University Press, 2005.

SHAVELL, Steven. Acquisition and disclosure of information prior to sale. The RAND Journal of Economics, v. 25, n. 1, p. 20-36, Spring, 1994.

. The allocation of risk and the theory of insurance. In: Economic analysis of accident law. Cambridge: Harvard University Press, 1987.

. Foundations of economic analysis of law. MA: Harvard Univiversity Press, 2004.

. On moral hazard and insurance. The Quarterly Journal of Economics, v. 93, n. 4, p. 541-562, Nov. 1979.

SILVA, Eva Sónia Moreira. Da responsabilidade pré-contratual por violação dos deveres de informação. Coimbra: Almedina, 2006.

SILVA, Ovídio Baptista da. Natureza jurídica do Monte Previdência. In: FÓRUM DE DIREITO DO SEGURO JOSÉ SOLLERO FILHO. ESTUDOS DE DIREITO DO SEGURO, São Paulo: IBDS-EMTS, 2002.

. Relações jurídicas comunitárias e direito subjetivo. In: FÓRUM DE DIREITO DO SEGURO JOSÉ SOLLERO FILHO. ESTUDOS DE DIREITO DO SEGURO, São Paulo: Max Limonad, 2000.

SIMON, Herbert A. A behavioral model of rational choice. The Quarterly Journal of Economics, v. 69, n. 1, p. 99-118, Feb. 1955.

. Rationality as process and as product of thought. The American Economic Review, v. 68 , n. 2, May, 1978.

. Rationality in psychology and economics. The Journal of Business, v. 59, n. 4, p. S209-S224, Oct. 1986.

SIMS, Vanessa. Good faith in English contract law: of triggers and concentric circles. Ankara Law Review, v. 1, n. 2, p. 213-232, 2004.

SPENCE, Michael. Job market signaling. Quarterly Journal of Economics, n. 87, n. 3, p. 355-374, Aug. 1973. 
SPENCE, Michael. Signaling in retrospect and the informational structure of markets. American Economic Review, n. 92, p. 434-459, 2002.

; ZECKHAUSER, Richard. Insurance, information, and individual action. The American Economic Review, v. 61, n. 2, p. 380-387, May, 1971. Papers and Proceedings of the Eighty- Third Annual Meeting of the American Economic Association.

STEYN, Lord Steyn. Contract law: fulfilling the reasonable expectations of honest men. Law Quarterly Review, n. 113, p. 433-439, 1997.

STIGLER, George J. The economics of information. The Journal of Political Economy, v. 69, n. 3, p. 213-225, Jun. 1961.

. Information in the labor market. Journal of Political Economy, v. 70, n. 5, p. 94105, Oct. 1962. Part 2: Investing in Human Beings.

. The theory of economic regulation. The Bell Journal of Economics and Management Science. v. 2, n. 1. p. 3-21, Spring, 1971.

STIGLITZ, Joseph. The contributions of the economics of information to twentieth century economics. The Quarterly Journal of Economics, v. 115, n. 4, p. 1441-1478, Nov. 2000.

; WEISS, Andrew. Credit rationing in markets with imperfect information. The American Economic Review, v. 71, n. 3, p. 393-410, Jun., 1981.

STIGLITZ, Rubén S. Derecho de seguros. 5. ed. actual. y ampl. Buenos Ayres: La Ley, 2008. t. 1.

. La obligatión precontractual y contractual de información: el deber de conselho. Revista de Direito do Consumidor, São Paulo, n. 22, abr./jun. 1997.

SUMMERS, Robert. Conceptualisation of good faith in American contract law: a general account. In: BEATSON, Jack; FRIEDMANN, Daniel (Eds.). Good faith and fault in contract law. 1995, rep. 2002. Oxford: Claredon Press, 2002. p. 118-141.

. The general duty of good faith - its recognition and conceptualization. Cornell Law Review, n. 67, p. 831-840, 1982.

Good faith in general contract law and the sales provisions of the Uniform Commercial Code. Virginia Law Review, n. 54, p. 195-267, Mar. 1968.

SZTAJN, Rachel. Externalidades e custos de transação: a redistribuição de direitos no novo Código Civil. Revista de Direito Mercantil, Industrial, Econômico e Financeiro, São Paulo, n. 133, p. 7-31, jan./mar. 2004. 
SZTAJN, Rachel. Função social do contrato e direito de empresa. In: TIMM, Luciano Benetti; MACHADO, Rafael Bicca (Coords.). Função social do direito. São Paulo: Quartier Latin, 2009.

. Notas de análise econômica: contratos e responsabilidade civil. Revista de Direito Mercantil, Industrial, Econômico e Financeiro, São Paulo, n. 111, jul./set. 1998.

- Seguro de dano moral resultante de acidente com veículo automotor. Revista de Direito Mercantil, Econômico e Financeiro, São Paulo, n. 106, p. 25-34, abr.jun. 1997. . Sistema financeiro. Rio de Janeiro: Elsevier, 2011.

; ZYLBERSZTAJN, Decio. Direito e economia. Rio de Janeiro: Elsevier, 2005.

TARR, Julie-Anne. Information disclosure: consumers, insurers and insurance contracting process. Lincoln: Authors Choice Press, 2001.

TETLEY, William. Good faith in contract - particularly in the contracts of arbitration and chartering. Journal of Maritime Law and Commerce, v. 35, n. 3, p. 561-616, 2004.

TIMM, Luciano Benetti; MACHADO, Rafael Bicca (Coord.). Função social do direito. São Paulo: Quartier Latin, 2009.

; Direito, mercado e função social. (Coords.). Função social do direito. São Paulo: Quartier Latin, 2009.

TOMASETTI JUNIOR, Alcides. O objetivo de transparência e o regime jurídico dos deveres e riscos de informação nas declarações negociais para consumo. In: NERY JR., Nelson; NERY, Rosa Maria de Andrade (Orgs.). Doutrinas essenciais: responsabilidade civil: direito das obrigações e direito negocial. 2. tir. São Paulo: Ed. Revista dos Tribunais, 2010. v. 2.

TOMASEVICIUS FILHO, Eduardo. Informação assimétrica, custos de transação, princípio da boa-fé. 2007. Tese (Doutorado) - Faculdade de Direito da USP, Universidade de São Paulo, São Paulo, 2007.

TREBILCOCK, Michael J. The limits of freedom of contract. Harvard University Press, 1997.

TVERSKY, Amos; KAHNEMAN, Daniel. Prospect theory: an analysis of decision under risk. Econometrica, v. 47, n. 2, p. 263-291, Mar. 1979.

; Rational choice and the framing of decisions. The Journal of Business, v. 59, n. 4, Out. 1986. Part 2: The Behavioral Foundations of Economic Theory. 
TZIRULNIK, Ernesto. Regulação de sinistro (ensaio jurídico). São Paulo: Max Limonad, 2001.

; CAVAlCANTI, Flávio de Queiroz. B.; PIMENTEL, Ayrton. O contrato de seguro de acordo com o novo Código Civil brasileiro. 2. ed. São Paulo: Ed. Revista dos Tribunais, 2003.

VARIAN, Hal R. Microeconomia: princípios básicos - uma abordagem moderna. Trad. da 7. ed. Trad. Maria J. Cyhlar Monteiro e Ricardo Doninelli. Rio de Janeiro: Elsevier, 2006.

VAUGHAN, Emmett J.; VAUGHAN, Therese M. Fundamentals of risk and insurance. $10^{\text {th }}$. ed. New Jersey: John Wiley \& Sons, Inc, 2008.

VEIGA COPO, Abel B.; SÁNCHEZ GRAELLS, Albert. Discriminación por razón de sexo y prima del contrato de seguro. Disponível em: <http://ssrn.com/abstract=1844492>.

VIVANTE, Cesare. Del contratto di assicurazione. Torino: Unione Tipografico - Editrice Torinese, 1936.

. Tratatto de diritto commerciale. Torino: Fratelli Bocca, 1905. v. 1 e v. 4.

WALD, Arnoldo. Direito civil: contratos em espécie. São Paulo: Saraiva, 2009.

ZIMMERMAN, Reinhard; WHITTAKER, Simon (Eds.). Good faith in European contract law. Cambridge: Cambridge University Press, 2000. 